\title{
Ground-Water Quality of the Southern High Plains Aquifer, Texas and New Mexico, 2001
}

NATIONAL WATER-QUALITY ASSESSMENT PROGRAM

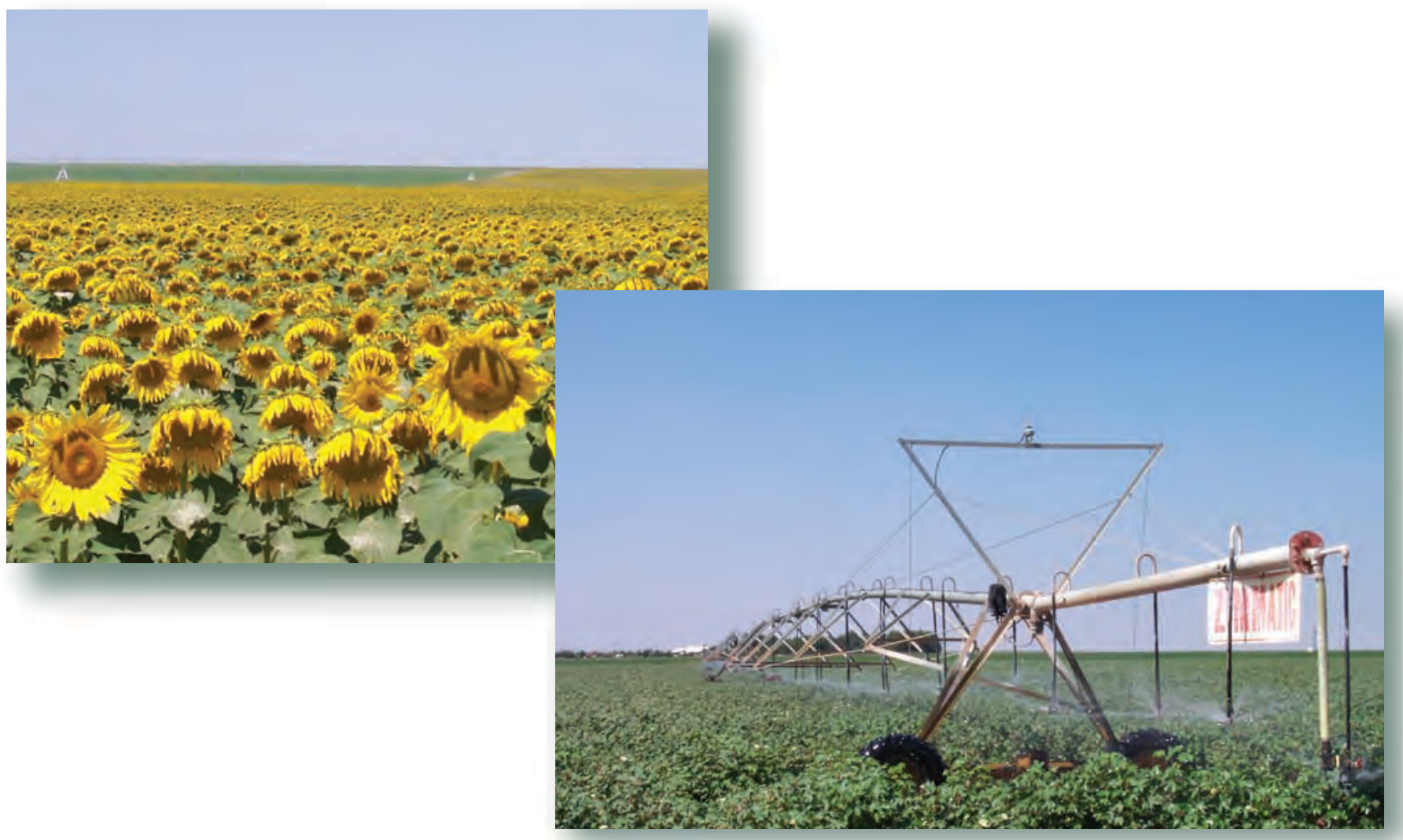

Open-File Report 03-345

U.S. Department of the Interior

U.S. Geological Survey 
Oilseed crops also are abundant on the southern High Plains.

About 20 to 25 percent of the Nation's cotton is grown on the southern High Plains. Both dry-land and irrigated cotton are important crops to the region. 
U.S. Department of the Interior

U.S. Geological Survey

\section{Ground-Water Quality of the Southern High Plains Aquifer, Texas and New Mexico, 2001}

By Lynne Fahlquist

Open-File Report 03-345

Prepared as part of the NATIONAL WATER-QUALITY ASSESSMENT PROGRAM

Austin, Texas

2003 


\section{U.S. DEPARTMENT OF THE INTERIOR}

Gale A. Norton, Secretary

\section{U.S. GEOLOGICAL SURVEY}

Charles G. Groat, Director

Any use of trade, product, or firm names in this publication is for descriptive purposes only and does not imply endorsement by the U.S. Government

For additional information write to:

\section{District Chief}

U.S. Geological Survey 8027 Exchange Dr. Austin, Texas 78754-4733

E-mail: dc_tx@usgs.gov
Copies of this report can be purchased from:

U.S. Geological Survey

Information Services

Box 25286

Denver, CO 80225-0286

E-mail: infoservices@usgs.gov

Information regarding the National Water-Quality Assessment (NAWQA) Program is available on the Internet via the World Wide Web. You may connect to the NAWQA Home Page using the Universal Resource Locator (URL) at:

<URL:http://water.usgs.gov/nawqa/> 


\section{FOREWORD}

The U.S. Geological Survey (USGS) is committed to serve the Nation with accurate and timely scientific information that helps enhance and protect the overall quality of life, and facilitates effective management of water, biological, energy, and mineral resources. Information on the quality of the Nation's water resources is of critical interest to the USGS because it is so integrally linked to the long-term availability of water that is clean and safe for drinking and recreation and that is suitable for industry, irrigation, and habitat for fish and wildlife. Escalating population growth and increasing demands for the multiple water uses make water availability, now measured in terms of quantity and quality, even more critical to the long-term sustainability of our communities and ecosystems.

The USGS implemented the National WaterQuality Assessment (NAWQA) Program to support national, regional, and local information needs and decisions related to water-quality management and policy. Shaped by and coordinated with ongoing efforts of other Federal, State, and local agencies, the NAWQA Program is designed to answer: What is the condition of our Nation's streams and ground water? How are the conditions changing over time? How do natural features and human activities affect the quality of streams and ground water, and where are those effects most pronounced? By combining information on water chemistry, physical characteristics, stream habitat, and aquatic life, the NAWQA Program aims to provide science-based insights for current and emerging water issues and priorities. NAWQA results can contribute to informed decisions that result in practical and effective water-resource management and strategies that protect and restore water quality.

Since 1991, the NAWQA Program has implemented interdisciplinary assessments in more than 50 of the Nation's most important river basins and aquifers, referred to as Study Units. In addition, the NAWQA Program initiated a regional ground-water assessment of the High Plains aquifer that extends from Texas to South Dakota. Collectively, NAWQA assessments account for more than 60 percent of the overall water use and population served by public water supply, and are representative of the Nation's major hydrologic landscapes, priority ecological resources, and agricultural, urban, and natural sources of contamination.

NAWQA assessments are guided by a nationally consistent study design and methods of sampling and analysis. The assessments thereby build local knowledge about water-quality issues and trends in a particular stream or aquifer while providing an understanding of how and why water quality varies regionally and nationally. The consistent, multi-scale approach helps to determine if certain types of water-quality issues are isolated or pervasive, and allows direct comparisons of how human activities and natural processes affect water quality and ecological health in the Nation's diverse geographic and environmental settings. Comprehensive assessments on pesticides, nutrients, volatile organic compounds, trace metals, and aquatic ecology are developed at the national scale through comparative analysis of the Study-Unit findings.

The USGS places high value on the communication and dissemination of credible, timely, and relevant science so that the most recent and available knowledge about water resources can be applied in management and policy decisions. We hope this NAWQA publication will provide you the needed insights and information to meet your needs, and thereby foster increased awareness and involvement in the protection and restoration of our Nation's waters.

The NAWQA Program recognizes that a national assessment by a single program cannot address all water-resource issues of interest. External coordination at all levels is critical for a fully integrated understanding of watersheds and for cost-effective management, regulation, and conservation of our Nation's water resources. The Program, therefore, depends extensively on the advice, cooperation, and information from other Federal, State, interstate, Tribal, and local agencies, non-government organizations, industry, academia, and other stakeholder groups. The assistance and suggestions of all are greatly appreciated.

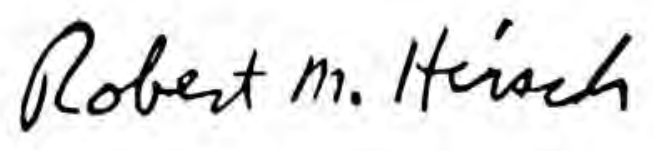

Robert M. Hirsch Associate Director for Water 


\section{CONTENTS}

Abstract n...

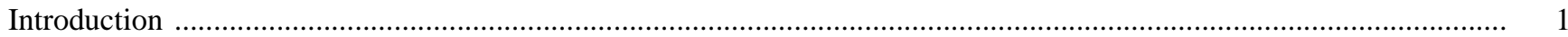

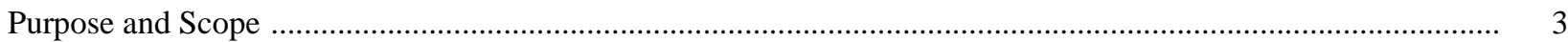

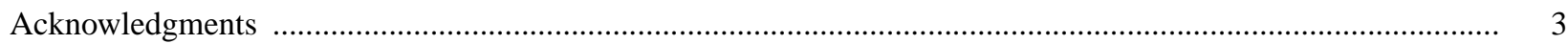

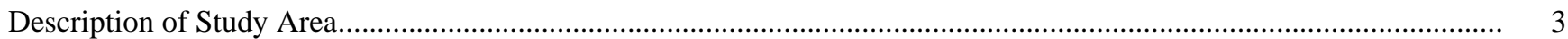

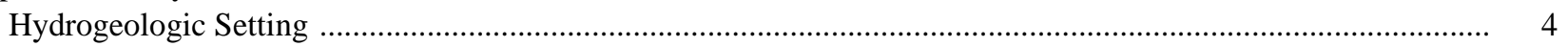

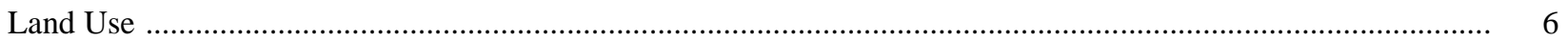

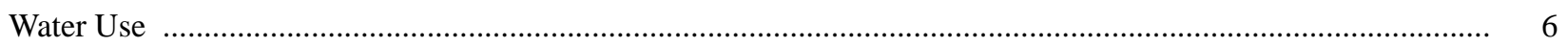

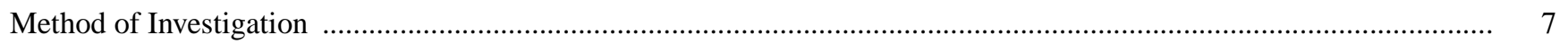

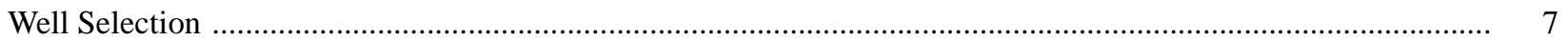

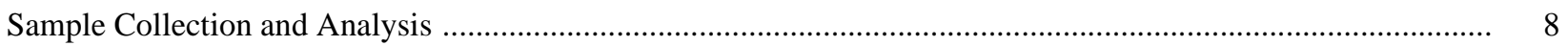

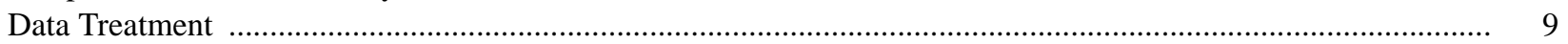

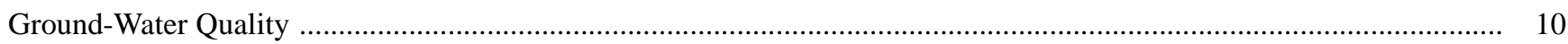

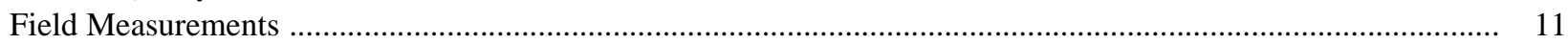

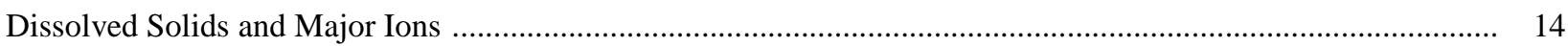

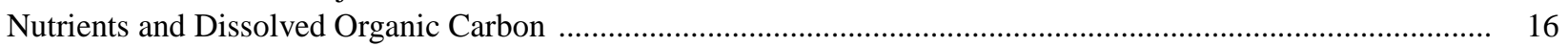

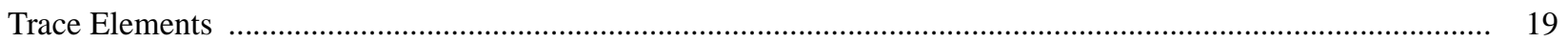

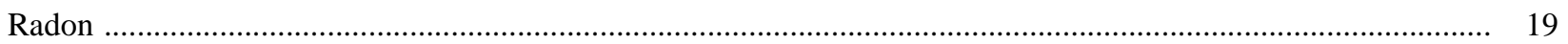

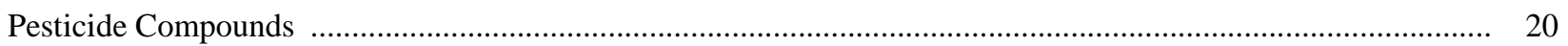

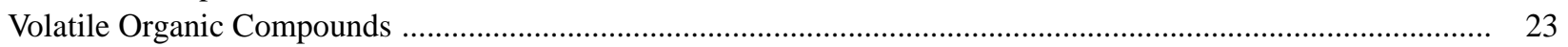

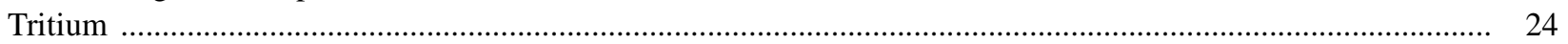

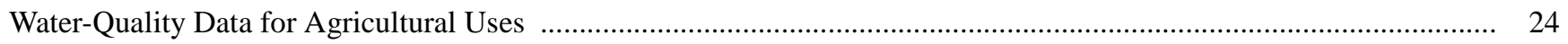

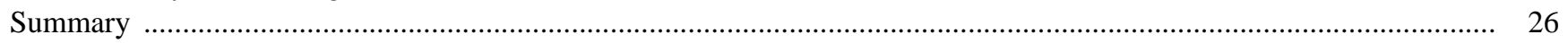

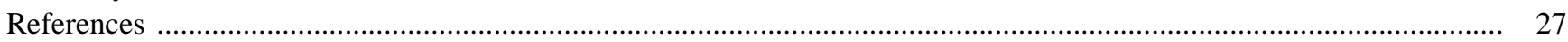

Appendixes

1. Site location and well information for samples collected from primarily domestic wells screened in the southern High Plains aquifer that were sampled for water quality, Texas and New Mexico, 2001

2. Field determinations and major ion concentrations in water sampled from primarily domestic wells

screened in the southern High Plains aquifer, Texas and New Mexico, 2001 ...................................................... Nutrients and dissolved organic carbon concentrations in water sampled from primarily domestic wells screened in the southern High Plains aquifer, Texas and New Mexico, 2001 .....

4. Trace element concentrations in water sampled from primarily domestic wells screened in the southern High Plains aquifer, Texas and New Mexico, 2001

5. Radon and tritium concentrations in water sampled from primarily domestic wells screened in the southern High Plains aquifer, Texas and New Mexico, 2001

Pesticide concentrations in water sampled from primarily domestic wells screened in the southern

High Plains aquifer, Texas and New Mexico, 2001.

7. Volatile organic compound concentrations in water sampled from primarily domestic wells screened in the southern High Plains aquifer, Texas and New Mexico, 2001

8. Quality-control and ancillary information associated with water-quality data presented in this report

\section{FIGURES}

1. Map showing location of the southern High Plains study area relative to the National Water-Quality Assessment High Plains Regional Ground-Water study area ..................................................................

2. Map showing land use over the southern High Plains aquifer, Texas and New Mexico, 1992 ......................... 4

3. Pie diagram showing estimated water use, in percent, in the southern High Plains aquifer, about 1999 ............ 7 
4. Map showing location of primarily domestic wells that are screened in the southern High Plains aquifer and were sampled for water-quality analysis, Texas and New Mexico, 2001

5. Graph showing concentrations of selected constituents, relative to USEPA drinking-water standards or guidelines, in water sampled from primarily domestic wells screened in the southern High Plains aquifer, Texas and New Mexico, 2001

6. Trilinear diagram showing the relations between concentrations of major ions in water sampled from primarily domestic wells screened in the southern High Plains aquifer, Texas and New Mexico, 2001

7-12. Maps showing:

7. Dissolved solids concentrations in water sampled from primarily domestic wells screened in the southern High Plains aquifer, Texas and New Mexico, 2001

8. Fluoride concentrations in water sampled from primarily domestic wells screened in the southern High Plains aquifer, Texas and New Mexico, 2001

9. Nitrate concentrations in water sampled from primarily domestic wells screened in the southern High Plains aquifer, Texas and New Mexico, 2001

10. Arsenic concentrations in water sampled from primarily domestic wells screened in the southern High Plains aquifer, Texas and New Mexico, 2001

11. Radon concentrations in water sampled from primarily domestic wells screened in the southern High Plains aquifer, Texas and New Mexico, 2001

12. Pesticide analysis results in water sampled from primarily domestic wells screened in the southern High Plains aquifer, Texas and New Mexico, 2001

13. Boxplots showing pesticide concentrations, relative to the national range, in water sampled from primarily domestic wells screened in the southern High Plains aquifer, Texas and New Mexico, 2001

14. Map showing location of sites with one or more indicators of young (approximately less than 50 years) ground water determined from water samples collected from primarily domestic wells screened in the southern High Plains aquifer, Texas and New Mexico, 2001

\section{TABLES}

1. References for analytical methods used to measure constituents in water samples collected from primarily domestic wells screened in the southern High Plains aquifer, Texas and New Mexico, 2001

2. Statistical summary of well properties and constituents in water sampled from primarily domestic wells screened in the southern High Plains aquifer, Texas and New Mexico, 2001 
CONVERSION FACTORS AND ABBREVIATIONS

\begin{tabular}{|c|c|c|}
\hline Multiply & By & To obtain \\
\hline \multirow{3}{*}{ pound (lb) } & Mass & \\
\hline & 453.6 & gram \\
\hline & Length & \\
\hline foot $(\mathrm{ft})$ & 0.3048 & meter \\
\hline \multirow[t]{2}{*}{ mile (mi) } & 1.609 & kilometer \\
\hline & Area & \\
\hline acre & 4,047 & square meter \\
\hline \multirow[t]{2}{*}{ square mile $\left(\mathrm{mi}^{2}\right)$} & 2.590 & square kilometer \\
\hline & Volume & \\
\hline \multirow[t]{2}{*}{ acre-foot (acre-ft) } & 1,233 & cubic meters \\
\hline & Flow rate & \\
\hline \multirow{3}{*}{$\begin{array}{r}\text { gallon per minute }(\mathrm{gal} / \mathrm{min}) \\
\text { inch per year }(\mathrm{in} / \mathrm{yr})\end{array}$} & 0.06309 & liter per second \\
\hline & 25.4 & millimeter per year \\
\hline & Radioactivity & \\
\hline \multirow[t]{2}{*}{ picocurie per liter (pCi/L) } & 0.312 & tritium unit \\
\hline & Concentration & \\
\hline microgram per liter $(\mu \mathrm{g} / \mathrm{L})$ & 1 & part per billion \\
\hline milligram per liter $(\mathrm{mg} / \mathrm{L})$ & 1 & part per million \\
\hline milligram per liter (mg/L) & 0.058 & grain per gallon \\
\hline
\end{tabular}

Temperature in degrees Celsius $\left({ }^{\circ} \mathrm{C}\right)$ may be converted to degrees Fahrenheit $\left({ }^{\circ} \mathrm{F}\right)$ as follows:

$$
{ }^{\circ} \mathrm{F}=1.8^{\circ} \mathrm{C}+32
$$

Temperature in degrees Fahrenheit $\left({ }^{\circ} \mathrm{F}\right)$ may be converted to degrees Celsius $\left({ }^{\circ} \mathrm{C}\right)$ as follows:

$$
{ }^{\circ} \mathrm{C}=\left({ }^{\circ} \mathrm{F}-32\right) / 1.8
$$

\section{Abbreviations:}

$\mu \mathrm{S} / \mathrm{cm}$, microsiemens per centimeter at 25 degrees Celsius

NTU, nephelometric turbidity unit 


\title{
Ground-Water Quality of the Southern High Plains Aquifer, Texas and New Mexico, 2001
}

\author{
By Lynne Fahlquist
}

\section{Abstract}

In 2001, the U.S. Geological Survey National Water-Quality Assessment Program collected water samples from 48 wells in the southern High Plains as part of a larger scientific effort to broadly characterize and understand factors affecting water quality of the High Plains aquifer across the entire High Plains. Water samples were collected primarily from domestic wells in Texas and eastern New Mexico. Depths of wells sampled ranged from 100 to 500 feet, with a median depth of 201 feet. Depths to water ranged from 34 to 445 feet below land surface, with a median depth of 134 feet.

Of 240 properties or constituents measured or analyzed, 10 exceeded U.S. Environmental Protection Agency public drinking-water standards or guidelines in one or more samples-arsenic, boron, chloride, dissolved solids, fluoride, manganese, nitrate, radon, strontium, and sulfate. Measured dissolved solids concentrations in 29 samples were larger than the public drinking-water guideline of 500 milligrams per liter. Fluoride concentrations in 16 samples, mostly in the southern part of the study area, were larger than the public drinking-water standard of 4 milligrams per liter. Nitrate was detected in all samples, and concentrations in six samples were larger than the public drinking-water standard of 10 milligrams per liter. Arsenic concentrations in 14 samples in the southern part of the study area were larger than the new (2002) public drinking-water standard of 10 micrograms per liter. Radon concentrations in 36 samples were larger than a proposed public drinking-water standard of 300 picocuries per liter.
Pesticides were detected at very small concentrations, less than 1 microgram per liter, in less than 20 percent of the samples. The most frequently detected compounds were atrazine and breakdown products of atrazine, a finding similar to those of National Water-Quality Assessment aquifer studies across the Nation. Four volatile organic compounds were detected at small concentrations in six water samples. About 70 percent of the 48 primarily domestic wells sampled contained some fraction of recently (less than about 50 years ago) recharged ground water, as indicated by the presence of one or more pesticides, or tritium or nitrate concentrations greater than threshold levels.

\section{INTRODUCTION}

Knowledge of the quality of water resources is important to the Nation because of implications for human and aquatic health and because of the substantial costs associated with water management. In 1991, the U.S. Geological Survey (USGS) began implementation of the National Water-Quality Assessment (NAWQA) Program to characterize, in a nationally consistent manner, water quality of major surface- and groundwater resources of the Nation and to determine the natural and human factors that affect water quality (Gilliom and others, 1995). More than fifty major river basins or aquifer systems, which provide drinkingwater resources to more than 60 percent of the Nation's population and cover about one-half of the Nation's land area, have been or are being studied by the NAWQA Program.

One component of a NAWQA study is designed to systematically assess the occurrence and distribution of water-quality constituents for regionally important aquifer systems. The High Plains Regional GroundWater NAWQA Study began in June 1998 and represents a modification of the traditional NAWQA design 


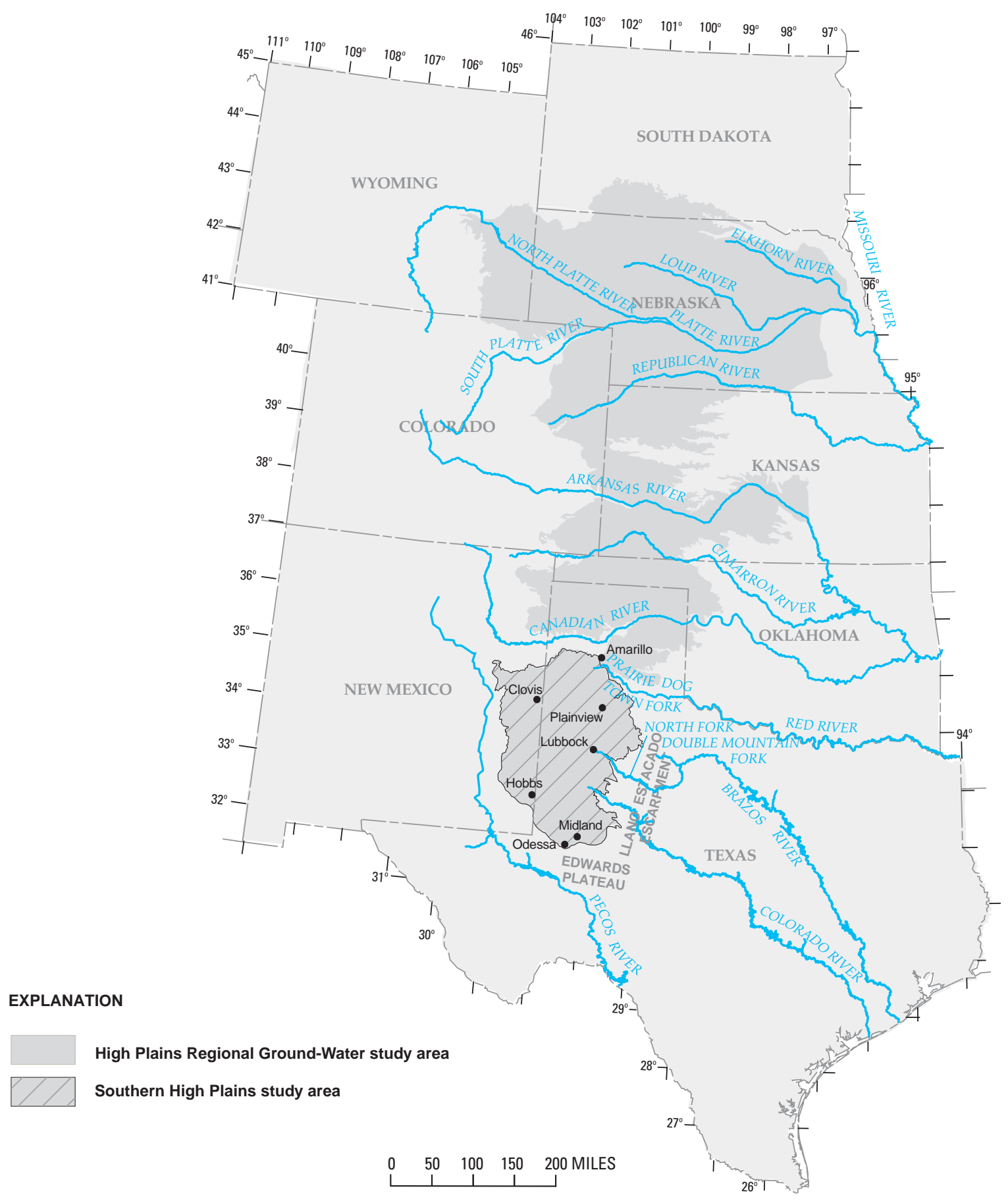

Figure 1. Location of the southern High Plains study area relative to the National Water-Quality Assessment High Plains Regional Ground-Water study area.

in that the ground-water resource is the primary focus of investigation. The High Plains aquifer, one of the largest in the world, is a nationally important water resource that underlies about 174,000 square miles $\left(\mathrm{mi}^{2}\right)$ in parts of eight states (fig. 1) in the central United States. About
27 percent of all agricultural land in the United States is in the High Plains region, and about 30 percent of all the ground water used for irrigation in the United States is pumped from this aquifer (Dennehy, 2000). The High Plains aquifer region was divided into three subareas for 
implementation of the study: northern, central, and southern. The High Plains aquifer was further divided into hydrogeologic subunits; subunits were defined by geologic or hydrologic characteristics, or both. The primary subunit in the High Plains region is the Ogallala Formation, which comprises about 70 percent of the High Plains aquifer (Gutentag and others, 1984). The 29,000-mi ${ }^{2}$ southern High Plains area spans much of the Panhandle-South Plains region of Texas and eastern New Mexico. Older hydrogeologic subunits might be important local water resources but were not part of this study.

The southern High Plains also is called the Llano Estacado, or "Staked Plain," a name that comes from early Spanish explorers who supposedly used stakes to mark their trails (Texas State Historical Association, 2002). Much of the vast, treeless landscape of the southern High Plains remained unchanged until the discovery of underground water in the late 1800s. When it was discovered that "windmill" water was present, cattle ranchers came to settle the region. Cattle ranchers were followed by farmers who plowed the land and began dry land farming. In the 1920s, the discovery of oil in the southern High Plains greatly changed the region. Technology developed for the oilfield was quickly adapted so that "deep" irrigation wells could be drilled and pumped. A vast, seemingly endless, supply of ground water was tapped, and irrigation farming on the southern High Plains began. Since the 1930s and 1940s, tens of thousands of wells in the southern High Plains have been drilled into one of the most productive aquifers in the world.

\section{Purpose and Scope}

The purpose of this report is to provide a broadscale description of ground-water quality in the southern High Plains aquifer of Texas and eastern New Mexico (fig. 2). Water samples collected in August and September 2001 from 48 randomly selected, primarily domestic water-supply wells were analyzed for six or seven field properties and 240 water-quality constituents. The constituents comprise major ions (17 constituents), nutrients (6), dissolved organic carbon (DOC), trace elements (23), radon gas, pesticide compounds (106), volatile organic compounds or VOCs (85), and tritium (small number of samples). Data collected for this study are compared to U.S. Environmental Protection Agency (USEPA) public drinking-water standards or guidelines (U.S. Environmental Protection Agency, 2002). One long-term goal of the NAWQA Program is to use data collected from this study and from other similar studies across the High Plains to develop a broad description of water quality of the entire High Plains aquifer (fig. 1), and identify and describe factors that affect water quality.

\section{Acknowledgments}

Cooperation among many individuals and organizations was essential for the completion of this study. The author is grateful for permissions granted by well owners for collection of water samples, without which the study could not have been accomplished. Also gratefully acknowledged are High Plains Underground Water Conservation District Number 1 (HPUWCD No. 1), Llano Estacado Underground Water Conservation District, Mesa Underground Water Conservation District, Sandy Land Underground Water Conservation District, South Plains Underground Water Conservation District, Permian Basin Underground Water Conservation District, Texas A\&M Agricultural Research and Extension Centers in Amarillo and Lubbock, Texas Cooperative Extension county offices in the study area, Texas Tech University, Texas Water Development Board (TWDB), and U.S. Department of Agriculture (USDA) Agricultural Research Service in Bushland, Tex. These agencies contributed to this study in many ways. The author appreciated enlightening and stimulating conversations with experts and residents of the region that provided a better understanding of the geology, hydrology, culture, and issues of the study area. Editorial contributions from Don McReynolds (HPUWCD No. 1) and Dana Porter (Texas A\&M Agricultural Research and Extension Center, Lubbock) greatly enhanced this report.

\section{DESCRIPTION OF STUDY AREA}

Delineation of the study-area boundaries for the southern High Plains was based on work completed as part of the USGS Regional Aquifer-System Analysis (RASA) Program (Weeks and others, 1988). The USGS RASA study, which described regional-scale quantity and movement of ground-water resources in the High Plains, identified boundaries of the High Plains aquifer in parts of eight states (fig. 1) and defined various hydrogeologic subunits within the aquifer (Gutentag and others, 1984). The southern High Plains study area (fig. 1) is bounded on the west by the Pecos River Basin, on the north by the Canadian River and Prairie Dog 


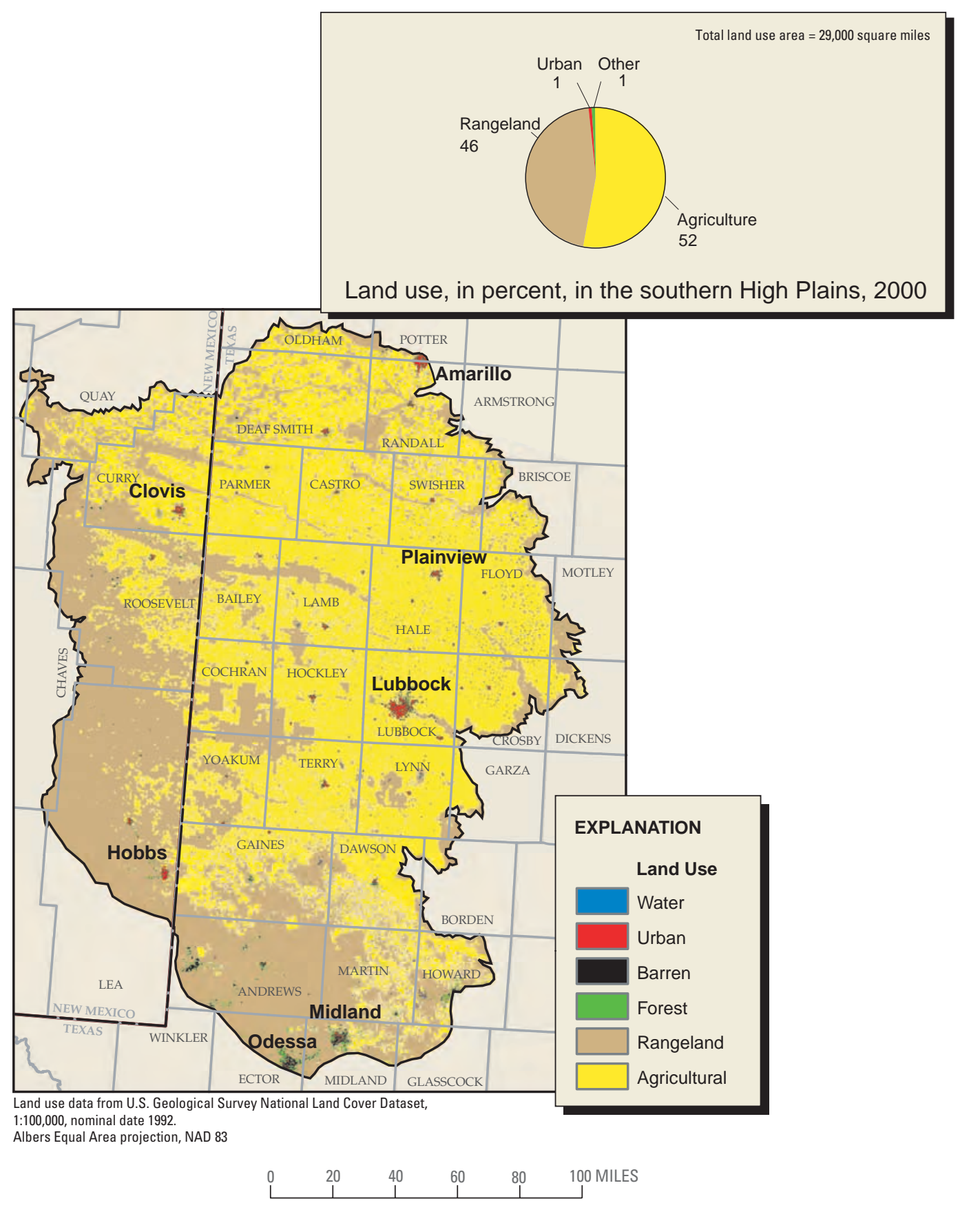

Figure 2. Land use over the southern High Plains aquifer, Texas and New Mexico, 1992.

Town Fork of the Red River Basin, and on the east by the Llano Estacado (Caprock) escarpment. The southern boundary is less distinct and is identified as where the Ogallala Formation thins, becomes unsaturated, and abuts the Edwards Plateau. The 29,000-mi ${ }^{2}$ study area includes all or parts of 37 counties in Texas and eastern New Mexico.

\section{Hydrogeologic Setting}

The southern High Plains region is an isolated plateau that slopes gently to the east-southeast. Land surface altitude varies from about 5,600 feet (ft) in the northwest (Quay County, N. Mex.) to about 2,700 ft in the southeast (Glasscock County, Tex.). The surface of 
this gently dipping plateau is dotted with thousands of closed-basin depressions called playas that vary in size and depth from a few hundred feet wide and a few feet deep to more than 1 mile (mi) wide and more than $50 \mathrm{ft}$ deep. Playas provide most surface relief to the area. Playas cover about 2 percent of the land surface and become ephemeral lakes when they capture rainfall or irrigation runoff; a few playas hold water year-round.

The climate is semiarid to subhumid. Annual mean precipitation varies from about 13 inches per year (in/yr) in the southwest to about $20 \mathrm{in} / \mathrm{yr}$ in the northeast (Bomar, 1983). Mean annual low temperature ranges from 44 to 50 degrees Fahrenheit $\left({ }^{\circ} \mathrm{F}\right)$, and mean annual high temperature ranges from 71 to $77^{\circ} \mathrm{F}$ from north to south. Most precipitation falls from May to October in the form of brief, localized showers. These "thunderstorms" can be violent, producing hail, high winds, lightening, and tornadoes. Evapotranspiration rates are some of the largest in the country because of frequent hot, dry weather and high winds.

Although five major river basins originate in the study area (Brazos, Canadian, Colorado, Pecos, and Red), almost no surface water leaves the plateau. A small number of mostly ephemeral streams drain the plateau and form the headwaters of most of the rivers. Some of the streams are impounded below escarpments to form reservoirs that provide a small contribution to the regional, mostly municipal, water supply.

The Ogallala Formation of Tertiary age primarily consists of alluvially deposited fluvial gravel, sand, silt, and clay eroded from the Rocky Mountains to the west (Seni, 1980). Coarse gravel and sand often fill deep paleochannels formed in the underlying formations. Finer sediments are in the interchannel regions. The highly variable distribution of coarse sediments influences the spatial distribution of porosity and permeability, hence the water-storage capacity, in the aquifer. In the southern High Plains, the sediments lie unconformably over the Cretaceous-age Washita, Fredericksburg, and Trinity Groups and the Triassic-age Dockum Group. The Cretaceous and Triassic strata might be hydraulically connected to the Ogallala Formation in some areas, such that these older formations contribute water to the Ogallala Formation. Water from the older formations is known to be of poorer quality in some areas (Nativ, 1988). The Ogallala Formation is overlain by aeolian, fluvial, and lacustrine sediments known as the Blackwater Draw Formation in much of the study area. At the surface, soils vary from mostly clay and clay loams in the north to sandy loams in the south
(Crenwelge, 1999). A resistant layer of carbonate or siliceous caliche, locally called caprock, is variably present in the subsurface. This layer, where present, might range from a few feet thick to more than $20 \mathrm{ft}$ thick and occurs at various depths below land surface.

In this study, the Ogallala and Blackwater Draw Formations are considered to be the southern High Plains aquifer, recognizing that the Triassic and Cretaceous Formations also might be hydraulically connected in some areas. The southern High Plains aquifer primarily is an unconfined aquifer; however, it might be confined in areas where clay layers are locally abundant. The regional water table generally mirrors the slope of the land surface, dipping to the east-southeast. In 2000, water-level altitudes varied from about 5,200 ft in the northwestern part of the study area to about 2,300 ft in the southeastern part. Water-table altitudes can change appreciably over short distances because of changes in geologic characteristics or ground-water withdrawals, or both. Total aquifer thickness varies from less than $20 \mathrm{ft}$ to more than $500 \mathrm{ft}$ in the study area. The thinnest parts of the aquifer generally are in the southern part of the study area, and the thickest parts are in Curry County, N. Mex., and in Castro, Crosby, Deaf Smith, Floyd, Lamb, and Parmer Counties, Tex. In 2000, saturated thickness varied from none in the southern part to greater than $200 \mathrm{ft}$ in some isolated areas in the northern part. Depths to water from land surface ranged from less than $100 \mathrm{ft}$ in much of the southern part to more than $400 \mathrm{ft}$ in isolated areas of the northern part (N.A. Houston, U.S. Geological Survey, written commun., 2002). Well yields range from as little as a few gallons per minute, sufficient yield for a household, to about 1,000 gallons per minute ( $\mathrm{gal} / \mathrm{min}$ ), good yield for an irrigation well (Texas Water Development Board, 2002a). Recharge to the aquifer might occur as direct infiltration of rainfall, infiltration of runoff accumulated in playas (Mullican and others, 1997; Wood, 2000), streambed leakage, or irrigation return flow. Recharge to the aquifer is presumed to be minimal and estimated to range from about 0.5 to $3 \mathrm{in} / \mathrm{yr}$ in the Llano Estacado and Panhandle Water Planning regions (Texas Water Development Board, 2002a, b). Currently (2001) almost all discharge from the aquifer is to wells, with only a few minor springs remaining along the escarpment and along deeply incised stream channels. 


\section{Land Use}

Despite the harsh climate, the southern High Plains is one of the most productive agricultural regions in the country. Cotton is the leading crop grown in the study area and is about 60 to 64 percent of the annual value of cotton that is grown in Texas (U.S. Department of Agriculture, 2002a), or 23 percent of the Nation's cotton (U.S. Department of Agriculture, 2002b). At least 25 percent of corn and 16 percent of sorghum in Texas is grown in this region (Texas Water Development Board, 2002a). Irrigated lands constitute about one-third of the agricultural land in the Llano Estacado Water Planning Region of Texas (Texas Water Development Board, 2002a), yet these lands produce about 75 percent of the cash value of crops in the region. Beef cattle also are economically important; about 50 percent of Texas beef cattle are raised in this water-planning region. About one-third of the Nation's beef cattle are raised within $150 \mathrm{mi}$ of Amarillo (Jaroy Moore, Texas A\&M Agricultural Research and Extension Center, Lubbock, oral commun., 2000).

Prior to settlement, the study area was predominantly a shortgrass prairie primarily grazed by bison. The bison are gone, and very little native vegetation remains. Rangeland, in the form of grasslands and shrubs, characterized from LandSat satellite imagery collected in 1992 (S.L. Qi, U.S. Geological Survey, written commun., 2002) constituted about 46 percent of the land use. Approximately 52 percent of the land use was agricultural, with much of that irrigated or dry-land farmed (fig. 2). In 2000, about 3.9 million acres were planted in cotton, 2 million acres in wheat, 1.7 million acres in sorghum, 329,000 acres in corn, and 214,000 acres in peanuts (U.S. Department of Agriculture, $2002 b)$. Other important crops in the region include soybeans, vegetables, and oilseed crops. Beef and dairy cattle and swine also are present in increasing numbers. About 2.75 million cattle were raised in the southern High Plains during 2000 (U.S. Department of Agriculture, 2002b). In 1992, urban and other land uses accounted for the remaining 2 percent of the land. A small percentage of the land where there is petroleum exploration and production often is used also for cattle ranching or farming. Even though playas occupy a small percentage of the land surface area, they provide extensive habitat for migrating birds. The playas primarily are found on private land and include habitat for migratory waterfowl (geese, ducks, sandhill cranes), other birds (quail, dove, turkey, pheasant), whitetail and mule deer, prairie dogs, and exotic aoudad sheep (Texas Water Development Board, 2002a).

Although far from being urban, the southern High Plains is the most populated part of the High Plains. In 1999, about 1 million people lived in the region (U.S. Census Bureau, 2002). Major cities in the study area (fig. 2) include Lubbock (population 190,002), Amarillo (171,959), Midland (98,293), Odessa $(89,293)$, and Plainview $(23,079)$ in Texas (Texas State Library and Archives Commission, 2002) and Clovis $(31,504)$ and Hobbs $(26,890)$ in New Mexico (University of New Mexico, Bureau of Business and Economic Research, 2002).

\section{Water Use}

In 1990, the High Plains aquifer in the eightstate area of the High Plains was estimated to contain 3.3 billion acre-feet (acre-ft) of water, of which about 65 percent was in Nebraska (Texas Water Development Board, 2002a). Texas had about 12 percent of the water in storage, or approximately 417 million acre-ft; and about 1.5 percent of the water was in New Mexico. In 1999, ground-water withdrawal from the southern High Plains aquifer was estimated to be 4.6 million acre-ft (Craig Caldwell, Texas Water Development Board, written commun., 2002; U.S. Geological Survey, unpub. data, 2002). This amount of water would fill an area the size of Lubbock County (fig. 2) to a depth of $8 \mathrm{ft}$.

Water use in the region is dominated by irrigation. Irrigated crops include corn, wheat, cotton, sorghum, soybeans, peanuts, and others. About 40 percent of irrigation water used in Texas is withdrawn in the southern High Plains (Texas Water Development Board, 2002a). In the study area, about 94 percent of the ground water was used for irrigation, about 2 percent for public supply, slightly more than 1 percent for livestock, about 1 percent for mining operations (including petroleum), and less than 1 percent each for power generation, industrial supply, and domestic supply (fig. 3). Surface water accounts for about 5 percent of water use in the study area (Texas Water Development Board, 2002a). Urban areas in the southern High Plains obtain drinking water mostly from ground water, and in some cases, blend ground water with surface water.

Some of the most efficient irrigation technology in the world has been developed and applied in the southern High Plains. Subsurface drip irrigation, low energy precision application (LEPA), low elevation 
spray application (LESA), and timed surge-valve irrigation systems are increasingly used. These irrigation technologies substantially increase irrigation application efficiency by reducing evaporative and conveyance losses.

\section{METHOD OF INVESTIGATION}

\section{Well Selection}

The study of ground-water quality in the southern High Plains followed design protocols described by Gilliom and others (1995) and Lapham and others (1995) developed for the NAWQA Program. Using an equal-area grid-based site-selection computer program (Scott, 1990), more than 250 sampling sites were randomly located over the northern, central, and southern High Plains. The computer program is used to remove human biases in site selection. Domestic wells suitable for sampling were identified near each randomly selected location to achieve a statistically determined random distribution of sites throughout the study area. Domestic wells were chosen for this study because they provide a range in spatial (areally and with depth) distribution in the High Plains aquifer, and they have

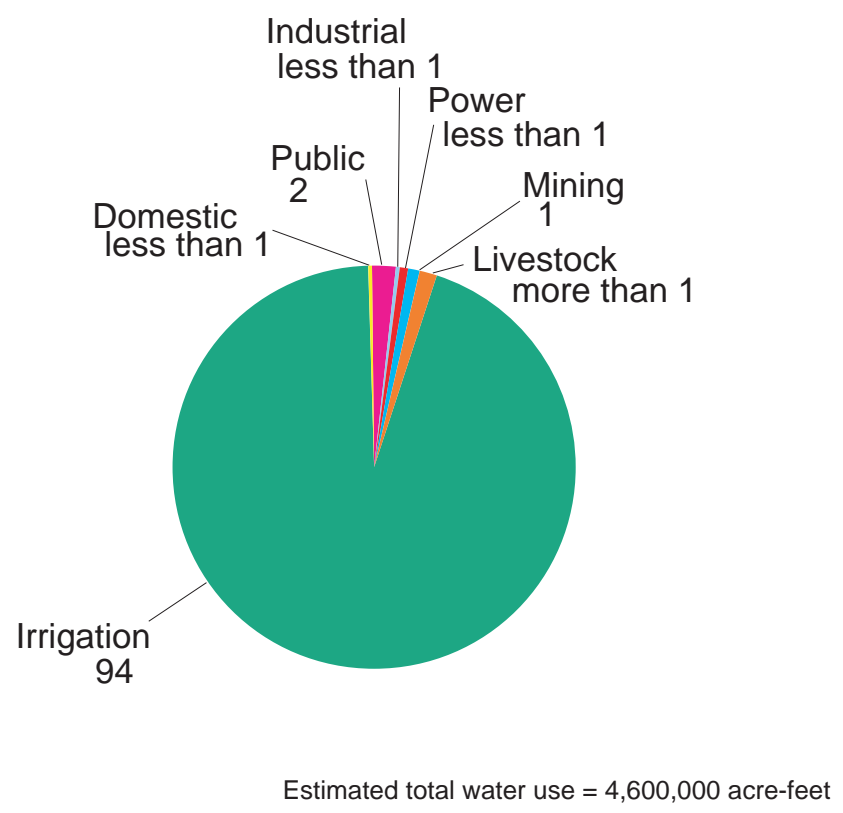

Figure 3. Estimated ground-water use, in percent, in the southern High Plains aquifer, about 1999 (1999 Texas data: Craig Caldwell, Texas Water Development Board, written commun., 2002; 1995 New Mexico data: U.S. Geological Survey, 2002). low-capacity pumping rates that limit the potential for withdrawal of water from large areas. Also, domestic wells were used because of the national objective of the NAWQA Program to further evaluate factors such as climate, hydrology, landscape, and geology on occurrence and distribution of constituents across the Nation. Domestic wells can be found in nearly all parts of the country, while other well types, such as irrigation and public supply, might be found in more restricted regions. A well was considered suitable for sampling if it (1) was within about a 4-mi radius of the randomly selected site; (2) was a domestic or equivalent well that was designed to be used as a drinking-water supply; (3) could be determined from a driller's log or other means that the well was completed in the southern High Plains aquifer; (4) had information that indicated the construction details of the well, including well depth, screened interval, and casing information; and (5) was possible to collect a water sample prior to any type of water treatment or storage, such as filtration, reverse osmosis, or storage in a pressure tank or cistern.

In the southern High Plains, 53 potential sampling locations were identified from which 48 sites (wells) were selected. The distribution of potential sampling locations represented a density of one well for each $500 \mathrm{mi}^{2}$. The average distance between wells was about $22 \mathrm{mi}$. Four of the selected locations, in the southernmost part of the study area, were in places where the Ogallala Formation is thin (less than $30 \mathrm{ft}$ thick) and not fully saturated. Wells in this region are completed in the formation below the Ogallala Formation such that wells are screened in both the Ogallala and the underlying Cretaceous sediments. Wells in these locations were unsuitable for the study because water-quality samples from them would not reflect water-quality conditions of the southern High Plains aquifer. One more well was eliminated from the study after reviewing water-quality data derived from that well. Although the well is completed in the southern High Plains aquifer, water chemistry indicated predominant influence by the adjacent geologic formation. Therefore, 48 wells (fig. 4 ) were ultimately identified as acceptable for meeting the objectives of the study. Three of the wells were used primarily for livestock but were judged as suitable because they were constructed and used similarly to domestic wells. Well depths ranged from 100 to $500 \mathrm{ft}$, with a median depth of $201 \mathrm{ft}$. Depths to water ranged from about 34 to $445 \mathrm{ft}$ below land surface, with a median depth of about $134 \mathrm{ft}$. Information about sample locations and well construction is provided in appendix 1 . 


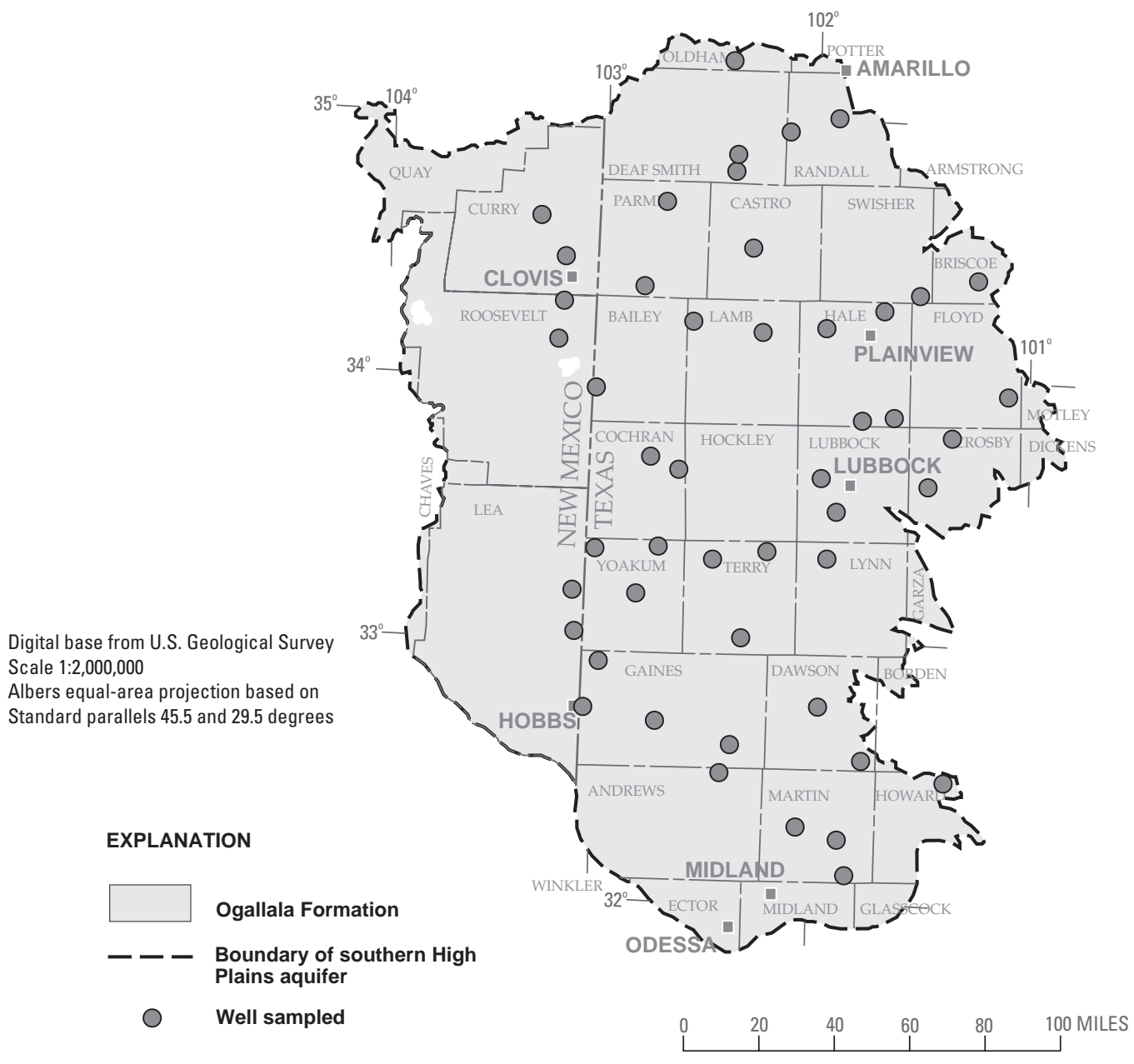

Figure 4. Location of primarily domestic wells that are screened in the southern High Plains aquifer and were sampled for water-quality analysis, Texas and New Mexico, 2001.

\section{Sample Collection and Analysis}

Water samples from the 48 wells were collected during August and September 2001 for a synoptic assessment of ground-water quality. Sampling protocols used for this study are described in detail in Koterba and others (1995), Koterba (1998), Lapham and others (1995), and U.S. Geological Survey (1997-present). Ground-water samples were collected and processed in a mobile water-quality laboratory. Existing primarily submersible pumps, permanently installed in each well, were used to deliver water to the land surface. In most cases, a permanent spigot near the wellhead was used as the sampling point. In a few instances, plumbing connections near the wellhead were modified temporarily for sampling purposes. Water was transferred from the wellhead spigot to the mobile laboratory using Teflon tubing with stainless steel fittings. These materials were used because they generally do not affect the chemical composition of water samples. To minimize risk of contamination, sample collection and preservation took place in environmental chambers consisting of clear polyethylene bags supported by plastic frames, much like a laboratory glove box. Equipment that came in contact with the water sample was cleaned between each well sampling using a progression of dilute phosphate-free detergent wash to remove both organic and inorganic residues, deionized water rinse to remove detergent, methanol wash to remove organic residue, and deionized water rinse to remove any remaining methanol residue.

Wells were purged of possible stagnant water before sampling. During the initial pumping period, 
Table 1. References for analytical methods used to measure constituents in water samples collected from primarily domestic wells screened in the southern High Plains aquifer, Texas and New Mexico, 2001

\begin{tabular}{|c|c|c|}
\hline $\begin{array}{l}\text { Constituent or } \\
\text { constituent group }\end{array}$ & Analytical method & Reference \\
\hline $\begin{array}{l}\text { Field measurements (alkalinity, } \\
\text { dissolved oxygen, } \mathrm{pH} \text {, specific } \\
\text { conductance, temperature, turbidity) }\end{array}$ & Various methods & Wilde and others, 1997 \\
\hline Sulfide & Methylene blue colorimetry & $\begin{array}{l}\text { U.S. Environmental Protection } \\
\text { Agency, } 1983\end{array}$ \\
\hline Major ions & Inductively coupled plasma & $\begin{array}{l}\text { American Public Health Association, } \\
\text { 1998; Fishman, 1993; Fishman and } \\
\text { Friedman, } 1989\end{array}$ \\
\hline Nutrients & Various methods & $\begin{array}{l}\text { Fishman, 1993; Patton and Truitt, } \\
\text { 2000; U.S. Environmental } \\
\text { Protection Agency, } 1983\end{array}$ \\
\hline Dissolved organic carbon & $\begin{array}{l}\text { Ultraviolet-light promoted persulfate } \\
\text { oxidation and infrared spectrometry }\end{array}$ & Brenton and Arnett, 1993 \\
\hline Trace elements & $\begin{array}{l}\text { Inductively coupled plasma-mass } \\
\text { spectrometry, atomic absorption } \\
\text { spectrometry }\end{array}$ & $\begin{array}{l}\text { Faires, 1993; Fishman and Friedman, } \\
\text { 1989; Garbarino, 1999; McClain, } \\
1993\end{array}$ \\
\hline Radon & Liquid scintillation & $\begin{array}{l}\text { American Society for Testing and } \\
\text { Materials, } 1996\end{array}$ \\
\hline Pesticide compounds & $\begin{array}{l}\text { Solid phase extraction using a C-18 } \\
\text { sorbent cartridge and capillary- } \\
\text { column gas chromatography/mass } \\
\text { spectrometry }\end{array}$ & $\begin{array}{l}\text { Furlong and others, 2001; Zaugg and } \\
\text { others, } 1995\end{array}$ \\
\hline Volatile organic compounds & $\begin{array}{l}\text { Purge and trap capillary column gas } \\
\text { chromatography/mass spectrometry }\end{array}$ & Connor and others, 1998 \\
\hline Tritium & $\begin{array}{l}\text { Eletrolytic enrichment and gas } \\
\text { counting }\end{array}$ & Thatcher and others, 1977 \\
\hline
\end{tabular}

measurements of specific conductance, $\mathrm{pH}$, water temperature, dissolved oxygen, and turbidity were routinely monitored in a sealed flow-through cell until stable observations were obtained. Once stable measurements of these properties were achieved (Koterba and others, 1995), it was assumed that stagnant water from the well bore had been removed and water samples then were collected. Stable measurements are identified when the variation between observations is less than a specified amount for five consecutive readings (Koterba and others, 1995; U.S. Geological Survey, 1997-present). Water was redirected by way of a manifold to the sample chamber inside the mobile laboratory for sample collection.

Additional parameters measured at the site were carbonate alkalinity and sulfide. Sulfide was measured when dissolved oxygen was less than 1 milligram per liter (mg/L). Samples collected and shipped for analysis included major ions (mineral analysis), nutrients (nitro- gen and phosphorus compounds), DOC, trace elements (mostly metals), radon gas, pesticide compounds (pesticides and their breakdown products), VOCs, and tritium. Tritium was analyzed in samples if there were no other indicators of young age (less than about 50 years). Chemical indicators of young age are nitrate concentration greater than $2.5 \mathrm{mg} / \mathrm{L}$ or detection of one or more pesticides, or both. Analytical results are listed in appendixes 2-7. Tritium was analyzed at one of the USGS National Research Program isotope laboratories, and all other analyses were performed at the USGS National Water Quality Laboratory. References that describe analytical methods used for this study are listed in table 1 .

\section{Data Treatment}

Water-quality data have been treated in the manner described below for presentation in this report. In 
addition to measured values, values with a less-than symbol are listed in appendixes 2-7. A discussion of quality control (QC) and ancillary information is provided in appendix 8. Less-than values were treated as nondetections; that is, constituents were not detected at or above the "less-than" concentration by the analytical procedure used. Nondetections were not included in statistical calculations and graphical plots where concentrations are used as variables.

In most cases, the less-than concentration is also the minimum reporting level (MRL) or laboratory reporting level (LRL). An MRL is defined by USGS as the smallest measured concentration of a constituent that might be reliably reported using a given analytical method (Timme, 1995), and an LRL is defined as generally equal to twice the yearly long-term method detection level (Childress and others, 1999). MRLs and LRLs vary among constituents and analytical methods and might vary over time. In general, measurement uncertainty increases substantially below an MRL or LRL. For this report, values that were measured at or below an MRL or LRL were treated as nondetections. In cases where multiple MRLs or LRLs were determined for an analyte, the largest MRL or LRL was used to censor detections below that value. The letter M is used to denote that a constituent was detected but the concentration could not be quantified. Because the concentration was not quantified, this designation also was treated as a nondetection. In some cases, the analytical method allows for concentrations to be semi-quantitatively estimated above the MRL or LRL. The letter E is shown in front of an estimated concentration. Estimated values greater than an MRL or LRL were treated as measured values; that is, the letter $\mathrm{E}$ was dropped from the analytical value so that graphical representations and statistical evaluations could be made with these data.

\section{GROUND-WATER QUALITY}

Most people in the southern High Plains primarily are concerned about ground-water resource sustainability from the perspective of water quantity, but waterquality information might become increasingly important as water levels decline. Nitrate, salinity, and pesticides have been identified in ground water in some areas of the High Plains (Dennehy, 2000; Dennehy and others, 2002; Litke, 2001; Mahler and others, 2002; Alan Cherepon, Texas Commission on Environmental Quality, oral commun., 2002). Water quality is particularly important in rural areas, where most of the popu- lation relies upon ground water for drinking. Rural homeowners are at greater risk than urban residents because their water supplies rarely are tested for many constituents that could affect human health. For this reason, ground-water quality of the southern High Plains aquifer is discussed in this report relative to USEPA public drinking-water standards or guidelines (U.S. Environmental Protection Agency, 2000, 2002). These standards are not enforceable for rural domestic drinking-water supplies. They are used here to present water-quality data in a context that is meaningful to those who consume untreated water from this aquifer. Some constituents, which might be natural or manufactured, have been determined to have adverse effects on human health; therefore, drinking-water standards or guidelines have been established to protect people who consume water from public drinking-water supplies (U.S. Environmental Protection Agency, 2000). A maximum contaminant level (MCL) is the maximum permissible level for a contaminant in drinking water that is delivered to any user of a public water system. A secondary maximum contaminant level (SMCL) is a nonenforceable guideline used for esthetic effects, such as odor, taste, or appearance of drinking water. A lifetime health advisory (HA), or maximum contaminant level goal (MCLG), is a nonenforceable guideline for a constituent in drinking water that might affect health.

Water from the southern High Plains aquifer generally is described as being of good quality, except for hardness associated with large concentrations of calcium and magnesium (Texas Water Development Board, 2002a). Historically, water in the northern part of the southern High Plains study area had dissolved concentrations smaller than $400 \mathrm{mg} / \mathrm{L}$, while the southern area had concentrations larger than $1,000 \mathrm{mg} / \mathrm{L}$, especially where the aquifer is underlain by Cretaceous sediments. Arsenic, chloride, dissolved solids, fluoride, nitrate, selenium, sulfate, and pesticides have been reported to exceed public drinking-water standards or guidelines in some areas (Ashworth and others, 1991; Hopkins, 1993; Knowles and others, 1982; Schriver and Hopkins, 1998; Alan Cherepon, Texas Commission on Environmental Quality, oral commun., 2002). Figure 5 is a graph of concentrations of selected major ions and related constituents sampled in this study. The USEPA drinking-water standards or guidelines are indicated for these selected constituents on figure 5. A statistical summary (minimum, median, and maximum values) of parameters that were measured or computed for this study is provided in table 2 . 


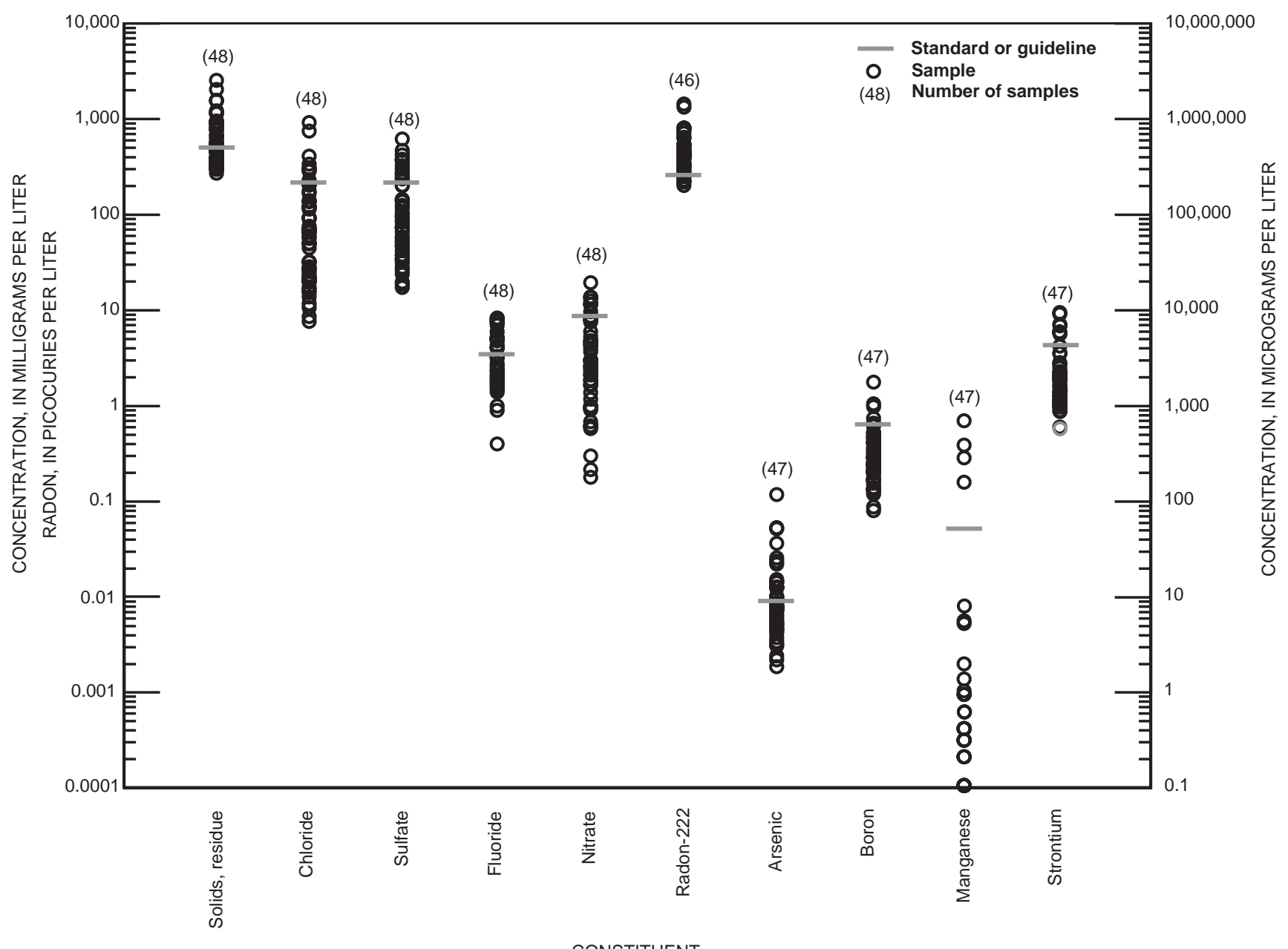

CONSTITUENT

Figure 5. Concentrations of selected constituents, relative to USEPA drinking-water standards or guidelines, in water sampled from primarily domestic wells screened in the southern High Plains aquifer, Texas and New Mexico, 2001.

\section{Field Measurements}

Field measurements (appendix 2) were made at the time of sample collection and include depth to water below land surface, specific conductance, $\mathrm{pH}$, water temperature, turbidity, dissolved oxygen, carbonate alkalinity, and sulfide if conditions warranted (dissolved oxygen less than $1 \mathrm{mg} / \mathrm{L}$ ).

Depth to water below land surface was measured where possible. If it was not possible to measure water depth at the sampled well, then an attempt was made to measure at a nearby well. If a nearby well was not available for measurement, then an historical water-level measurement for the sampled well is reported. Depth to water might be useful for interpreting water-quality data.

Specific conductance is a measure of the ability of water to conduct an electrical current and provides an indication of the amount of ions dissolved in water. The ability of water to conduct electricity increases as more ions are dissolved; therefore, larger values of specific conductance indicate larger dissolved ions (dissolved solids) concentrations, also referred to as salinity, in water. Water samples had specific conductance values ranging from 455 to 4,090 microsiemens per centimeter at $25^{\circ} \mathrm{C}(\mu \mathrm{S} / \mathrm{cm})$, and the median value was $853 \mu \mathrm{S} / \mathrm{cm}$. The range of measurements for this study indicates some of the water is high in dissolved solids and might be esthetically objectionable. 
Table 2. Statistical summary of well properties and constituents in water sampled from primarily domestic wells screened in the southern High Plains aquifer, Texas and New Mexico, 2001

[ft, feet; --, not applicable; $\mu \mathrm{S} / \mathrm{cm}$, microsiemens per centimeter at 25 degrees Celsius; ${ }^{\circ} \mathrm{C}$, degrees Celsius; NTU, nephelometric turbidity unit; $\mathrm{mg} / \mathrm{L}$, milligrams per liter; $\mathrm{CaCO}_{3}$, calcium carbonate; $\mu \mathrm{g} / \mathrm{L}$, micrograms per liter; $\mathrm{pCi} / \mathrm{L}$, picocuries per liter]

\begin{tabular}{|c|c|c|c|c|c|c|}
\hline \multirow[b]{2}{*}{ Property or constituent } & \multirow{2}{*}{$\begin{array}{c}\text { No. } \\
\text { of } \\
\text { samples }\end{array}$} & \multirow{2}{*}{$\begin{array}{c}\text { No. of } \\
\text { measure- } \\
\text { ments or } \\
\text { detections }\end{array}$} & \multicolumn{3}{|c|}{ Measurement or detection } & \multirow{2}{*}{$\begin{array}{c}\text { Public } \\
\text { drinking-water } \\
\text { standard or } \\
\text { guideline }\end{array}$} \\
\hline & & & $\begin{array}{l}\text { Mini- } \\
\text { mum }\end{array}$ & Median & $\begin{array}{l}\text { Maxi- } \\
\text { mum }\end{array}$ & \\
\hline \multicolumn{7}{|c|}{ Well properties } \\
\hline Total depth of well, (ft) & 48 & 48 & 100 & 201 & 500 & -- \\
\hline $\begin{array}{l}\text { Depth to middle of screened interval } \\
\text { from land surface }(\mathrm{ft})\end{array}$ & 48 & 48 & 80 & 177.5 & 490 & -- \\
\hline Length of screened interval (ft) & 48 & 48 & 10 & 40 & 186 & -- \\
\hline \multicolumn{7}{|c|}{ Field properties } \\
\hline Depth to water from land surface (ft) & 48 & 48 & 34 & 134 & 445 & -- \\
\hline Specific conductance $(\mu \mathrm{S} / \mathrm{cm})$ & 48 & 48 & 455 & 853 & 4,090 & -- \\
\hline pH (standard units) & 48 & 48 & 6.7 & 7.3 & 7.7 & $6.5-8.5$ \\
\hline Water temperature $\left({ }^{\circ} \mathrm{C}\right)$ & 48 & 48 & 17.4 & 19.2 & 23.7 & -- \\
\hline Turbidity (NTU) & 48 & 48 & .04 & .26 & 158 & 5.0 \\
\hline Dissolved oxygen (mg/L) & 48 & 48 & .4 & 5.4 & 9.3 & -- \\
\hline Alkalinity $\left(\mathrm{mg} / \mathrm{L} \mathrm{CaCO}_{3}\right)$ & 48 & 48 & 150 & 234 & 542 & -- \\
\hline \multicolumn{7}{|c|}{ Major ions } \\
\hline Bromide (mg/L) & 48 & 48 & .07 & .465 & 5.84 & -- \\
\hline Calcium (mg/L) & 48 & 48 & 18.9 & 56.25 & 240 & -- \\
\hline Chloride (mg/L) & 48 & 48 & 7.6 & 66 & 917 & 250 \\
\hline Fluoride (mg/L) & 48 & 48 & .4 & 2.4 & 8.3 & 4.0 \\
\hline Magnesium (mg/L) & 48 & 48 & 12.3 & 41.25 & 159 & -- \\
\hline Potassium (mg/L) & 48 & 47 & 2.31 & 7.75 & 29.1 & -- \\
\hline Silica $(\mathrm{mg} / \mathrm{L})$ & 48 & 48 & 25.1 & 45.9 & 82.4 & -- \\
\hline Sodium (mg/L) & 48 & 48 & 16.2 & 64.1 & 483 & -- \\
\hline Solids, dissolved, residue (mg/L) & 48 & 48 & 270 & 544 & 2,540 & 500 \\
\hline Sulfate $(\mathrm{mg} / \mathrm{L})$ & 48 & 48 & 16.9 & 89.4 & 603 & 250 \\
\hline \multicolumn{7}{|c|}{ Parameters computed from major-ion concentrations } \\
\hline Hardness $\left(\mathrm{mg} / \mathrm{L} \mathrm{CaCO}_{3}\right)$ & 48 & 48 & 100 & 300 & 1,200 & 120 \\
\hline Salinity (mg/L dissolved solids) & 48 & 48 & -- & -- & -- & ${ }^{1} 1,400-2,100$ \\
\hline Sodium adsorption ratio (SAR) & 48 & 48 & .4 & 1 & 16 & 19 \\
\hline Soluble sodium percentage (SSP) & 48 & 48 & 8.8 & 28.8 & 85.0 & ${ }^{1} 60$ \\
\hline \multicolumn{7}{|c|}{ Nutrients and dissolved organic carbon } \\
\hline Nitrate nitrogen $(\mathrm{mg} / \mathrm{L})$ & 48 & 48 & 0.179 & 2.98 & 19.5 & 10.0 \\
\hline Nitrite nitrogen (mg/L) & 48 & 1 & -- & .012 & -- & 1.0 \\
\hline Ammonia $(\mathrm{mg} / \mathrm{L})$ & 48 & 0 & -- & -- & -- & -- \\
\hline Ammonia + organic nitrogen (mg/L) & 48 & 13 & .11 & .13 & .31 & -- \\
\hline Phosphorus (mg/L) & 48 & 12 & .007 & .0095 & .047 & -- \\
\hline Orthophosphate (mg/L) & 48 & 2 & .025 & -- & .038 & -- \\
\hline Dissolved organic carbon $(\mathrm{mg} / \mathrm{L})$ & 47 & 38 & .37 & 1.0 & 3.4 & -- \\
\hline \multicolumn{7}{|c|}{ Trace elements } \\
\hline Aluminum $(\mu \mathrm{g} / \mathrm{L})$ & 47 & 1 & -- & 6 & -- & $50-200$ \\
\hline Antimony $(\mu \mathrm{g} / \mathrm{L})$ & 47 & 0 & -- & -- & -- & 6.0 \\
\hline
\end{tabular}


Table 2. Statistical summary of well properties and constituents in water sampled from primarily domestic wells screened in the southern High Plains aquifer, Texas and New Mexico, 2001—Continued

\begin{tabular}{|c|c|c|c|c|c|c|}
\hline \multirow[b]{2}{*}{ Property or constituent } & \multirow{2}{*}{$\begin{array}{c}\text { No. } \\
\text { of } \\
\text { samples }\end{array}$} & \multirow{2}{*}{$\begin{array}{c}\text { No. of } \\
\text { measure- } \\
\text { ments or } \\
\text { detections }\end{array}$} & \multicolumn{3}{|c|}{ Measurement or detection } & \multirow{2}{*}{$\begin{array}{c}\text { Public } \\
\text { drinking-water } \\
\text { standard or } \\
\text { guideline }\end{array}$} \\
\hline & & & $\begin{array}{l}\text { Mini- } \\
\text { mum }\end{array}$ & Median & $\begin{array}{l}\text { Maxi- } \\
\text { mum }\end{array}$ & \\
\hline \multicolumn{7}{|c|}{ Trace elements-Continued } \\
\hline Arsenic $(\mu \mathrm{g} / \mathrm{L})$ & 47 & 47 & 1.7 & 6.5 & 107 & 10 \\
\hline Barium $(\mu \mathrm{g} / \mathrm{L})$ & 47 & 47 & 24.1 & 62.5 & 382 & 200 \\
\hline Beryllium $(\mu \mathrm{g} / \mathrm{L})$ & 47 & 0 & -- & -- & -- & 4.0 \\
\hline Boron $(\mu \mathrm{g} / \mathrm{L})$ & 47 & 47 & 73 & 231 & 1,630 & 600 \\
\hline Cadmium $(\mu \mathrm{g} / \mathrm{L})$ & 47 & 1 & -- & .22 & -- & 5.0 \\
\hline Chromium $(\mu \mathrm{g} / \mathrm{L})$ & 47 & 1 & -- & 4.9 & -- & 100 \\
\hline Cobalt $(\mu \mathrm{g} / \mathrm{L})$ & 47 & 47 & .03 & .09 & .79 & -- \\
\hline Copper $(\mu \mathrm{g} / \mathrm{L})$ & 47 & 45 & .03 & 1.4 & 15.6 & 1,000 \\
\hline Iron $(\mu \mathrm{g} / \mathrm{L})$ & 48 & 1 & -- & 60 & -- & 300 \\
\hline Lead $(\mu \mathrm{g} / \mathrm{L})$ & 47 & 12 & .26 & .39 & 4.55 & 15 \\
\hline Lithium $(\mu \mathrm{g} / \mathrm{L})$ & 47 & 47 & 26.4 & 91.3 & 576 & -- \\
\hline Manganese $(\mu \mathrm{g} / \mathrm{L})$ & 47 & 14 & 6 & 3.45 & 671 & 50 \\
\hline Molybdenum $(\mu \mathrm{g} / \mathrm{L})$ & 47 & 47 & .5 & 4.7 & 46.4 & 40 \\
\hline Nickel $(\mu \mathrm{g} / \mathrm{L})$ & 47 & 5 & .42 & .70 & 2.19 & 100 \\
\hline Selenium $(\mu \mathrm{g} / \mathrm{L})$ & 47 & 47 & 6 & 62 & 38.7 & 50 \\
\hline Silver $(\mu \mathrm{g} / \mathrm{L})$ & 47 & 0 & -- & -- & -- & 100 \\
\hline Strontium $(\mu \mathrm{g} / \mathrm{L})$ & 47 & 47 & 565 & 1,460 & 9,340 & 4,000 \\
\hline Thallium $(\mu \mathrm{g} / \mathrm{L})$ & 47 & 0 & -- & -- & -- & 2.0 \\
\hline Uranium $(\mu \mathrm{g} / \mathrm{L})$ & 47 & 47 & .49 & 6.92 & 18.2 & 30 \\
\hline Vanadium $(\mu \mathrm{g} / \mathrm{L})$ & 47 & 47 & 9.4 & 37.2 & 190 & -- \\
\hline $\operatorname{Zinc}(\mu \mathrm{g} / \mathrm{L})$ & 47 & 42 & 2 & 9.5 & 251 & 5,000 \\
\hline \multicolumn{7}{|c|}{ Radionuclides } \\
\hline Radon-222 (pCi/L) & 46 & 46 & 202 & 428 & 1,440 & ${ }^{2} 300$ \\
\hline Tritium (pCi/L) & 16 & 2 & 3.2 & -- & 6.1 & -- \\
\hline \multicolumn{7}{|c|}{ Detected pesticide compounds } \\
\hline Atrazine $(\mu \mathrm{g} / \mathrm{L})$ & 48 & 5 & .011 & .012 & .115 & 3 \\
\hline Deethylatrazine $(\mu \mathrm{g} / \mathrm{L})$ & 48 & 4 & .037 & .118 & .234 & -- \\
\hline 2-Hydroxyatrazine $(\mu \mathrm{g} / \mathrm{L})$ & 48 & 1 & -- & .012 & -- & -- \\
\hline Deethyldeisopropyl atrazine $(\mu \mathrm{g} / \mathrm{L})$ & 48 & 1 & -- & .02 & -- & -- \\
\hline Deisopropylatrazine $(\mu \mathrm{g} / \mathrm{L})$ & 48 & 1 & -- & .06 & -- & -- \\
\hline Dacthal mono-acid $(\mu \mathrm{g} / \mathrm{L})$ & 48 & 1 & -- & .04 & -- & -- \\
\hline Dicamba $(\mu \mathrm{g} / \mathrm{L})$ & 48 & 1 & -- & .02 & -- & -- \\
\hline Malathion $(\mu \mathrm{g} / \mathrm{L})$ & 48 & 1 & -- & .029 & -- & 100 \\
\hline \multicolumn{7}{|c|}{ Detected volatile organic compounds } \\
\hline Trichloromethane (chloroform, $\mu \mathrm{g} / \mathrm{L}$ ) & 47 & 4 & .05 & .08 & 1.51 & 80 \\
\hline Tetrachloroethene (PCE, $\mu \mathrm{g} / \mathrm{L})$ & 47 & 1 & -- & .5 & -- & 5.0 \\
\hline Tetrahydrofuran $(\mu \mathrm{g} / \mathrm{L})$ & 47 & 1 & -- & 3 & -- & -- \\
\hline Methylethylketone $(\mu \mathrm{g} / \mathrm{L})$ & 47 & 1 & -- & 10 & -- & -- \\
\hline
\end{tabular}

${ }^{1}$ Standard or guideline applies to agriculture.

${ }^{2}$ Proposed public drinking-water standard. 
The $\mathrm{pH}$ of water samples was within the USEPA SMCL range of 6.5 to 8.5 standard units. The $\mathrm{pH}$ measurements ranged from 6.7 to 7.7 , in the neutral or near neutral range.

Turbidity is a measure of the clarity of water. It is desirable to have turbidity less than 5.0 nephelometric turbidity units (NTU) in public drinking water. Turbidity ranged from 0.04 to $158 \mathrm{NTU}$, with a median of 0.26 NTU. In the southern High Plains, turbidity greater than 5.0 NTU probably results from sand, silt, or clay particles in water or from the presence of organic matter. Five samples had turbidity equal to or greater than 5.0 NTU.

Water samples from nearly all of the wells were oxygenated; that is, dissolved oxygen concentrations were larger than $1 \mathrm{mg} / \mathrm{L}$. The range in dissolved oxygen concentrations was 0.4 to $9.3 \mathrm{mg} / \mathrm{L}$, with a median of $5.4 \mathrm{mg} / \mathrm{L}$. Four water samples had dissolved oxygen concentrations of less than $1.0 \mathrm{mg} / \mathrm{L}$. Sulfide was measured in three of the four water samples that had small dissolved oxygen concentrations, indicating reducing conditions might exist in a few of the wells that were sampled. Reducing conditions might allow the formation of compounds such as ammonia or hydrogen sulfide if certain constituents (for example, nitrogen and sulfur) are present in the water.

Alkalinity, reported as milligrams per liter of calcium carbonate, is a measure of dissolved carbonate and bicarbonate ions and is a measure of the capacity of water to react with and neutralize acid (Hem, 1985). Alkalinity in water samples ranged from 150 to 542 $\mathrm{mg} / \mathrm{L}$, with a median of $234 \mathrm{mg} / \mathrm{L}$. Water with large alkalinity might have a taste that is unpleasant. Irrigation water with excessive alkalinity might increase soil $\mathrm{pH}$, leach organic matter, decrease soil permeability, and impair plant growth.

\section{Dissolved Solids and Major Ions}

In this study, 60 percent of the samples from the southern High Plains aquifer had water analyses that were large (greater than $500 \mathrm{mg} / \mathrm{L}$ ) in dissolved solids. Water samples were variable in major ion composition and in large part reflect the mineral composition of rocks and sediments that compose the aquifer. The trilinear diagram shown in figure 6 is used to identify and classify water types. In general, water samples from the northern part of the study area (approximate northern boundaries of Cochran, Crosby, Hockley, and Lubbock Counties; north of latitude $33^{\circ} 50^{\prime}$ ) are calcium magne- sium bicarbonate waters, and water samples from the southern part of the study area (approximately south of latitude $33^{\circ} 50^{\prime}$ ) are calcium magnesium bicarbonate chloride sulfate waters, although both water types can be found in both regions. This latitude roughly corresponds to the northern extent of older Cretaceous sediments present in the subsurface, which might be a source of increased dissolved solids and trace elements.

Dissolved solids are an important indicator of the suitability of water for drinking, irrigation, and industrial use. Although drinking water containing more than $500 \mathrm{mg} / \mathrm{L}$ (USEPA SMCL) dissolved solids is esthetically undesirable, such water is used in many areas where less mineralized water is not available. Concentrations of measured dissolved solids in water samples ranged from 270 to $2,540 \mathrm{mg} / \mathrm{L}$ (appendix 2). The median dissolved solids concentration among 48 samples was $544 \mathrm{mg} / \mathrm{L}$, with concentrations in 29 samples equal to $500 \mathrm{mg} / \mathrm{L}$ or greater. Figure 7 shows concentrations of measured dissolved solids distributed across the study area. In general, samples with larger dissolved solids concentrations were from wells in the southern part of the study area. Dissolved solids concentrations measured for this study are consistent with those of previous studies (Nativ, 1988; Ashworth and others, 1991; Hopkins, 1993). Possible sources of larger dissolved solids concentrations in the southern part of the study area are underlying Cretaceous rocks, saline lakes, and oilfield brines (Nativ, 1988).

Rural domestic water tests often report a constituent called hardness. Hardness has been associated with the ability of water to remove soap or the presence of residue left by water (Hem, 1985). Water that is referred to as hard has concentrations larger than $120 \mathrm{mg} / \mathrm{L}$ (7 grains per gallon). Hardness, computed from calcium and magnesium concentrations, ranged from 100 to $1,200 \mathrm{mg} / \mathrm{L}$ (equivalents of calcium carbonate), with a median of $300 \mathrm{mg} / \mathrm{L}$. All but one of the 48 samples had concentrations larger than $120 \mathrm{mg} / \mathrm{L}$.

Concentrations of chloride and sulfate larger than $250 \mathrm{mg} / \mathrm{L}$, USEPA SMCL for these constituents, might produce an objectionable taste in drinking water. Large chloride concentrations might impart a salty taste and might accelerate the corrosion of metal pipes. Chloride concentrations ranged from 7.6 to $917 \mathrm{mg} / \mathrm{L}$, and the median concentration among 48 samples was 66.0 $\mathrm{mg} / \mathrm{L}$. Concentrations in seven samples were larger than $250 \mathrm{mg} / \mathrm{L}$. Large sulfate concentrations might impart a bitter taste and act as a laxative on unaccustomed users (Hem, 1985). Sulfate concentrations ranged from 


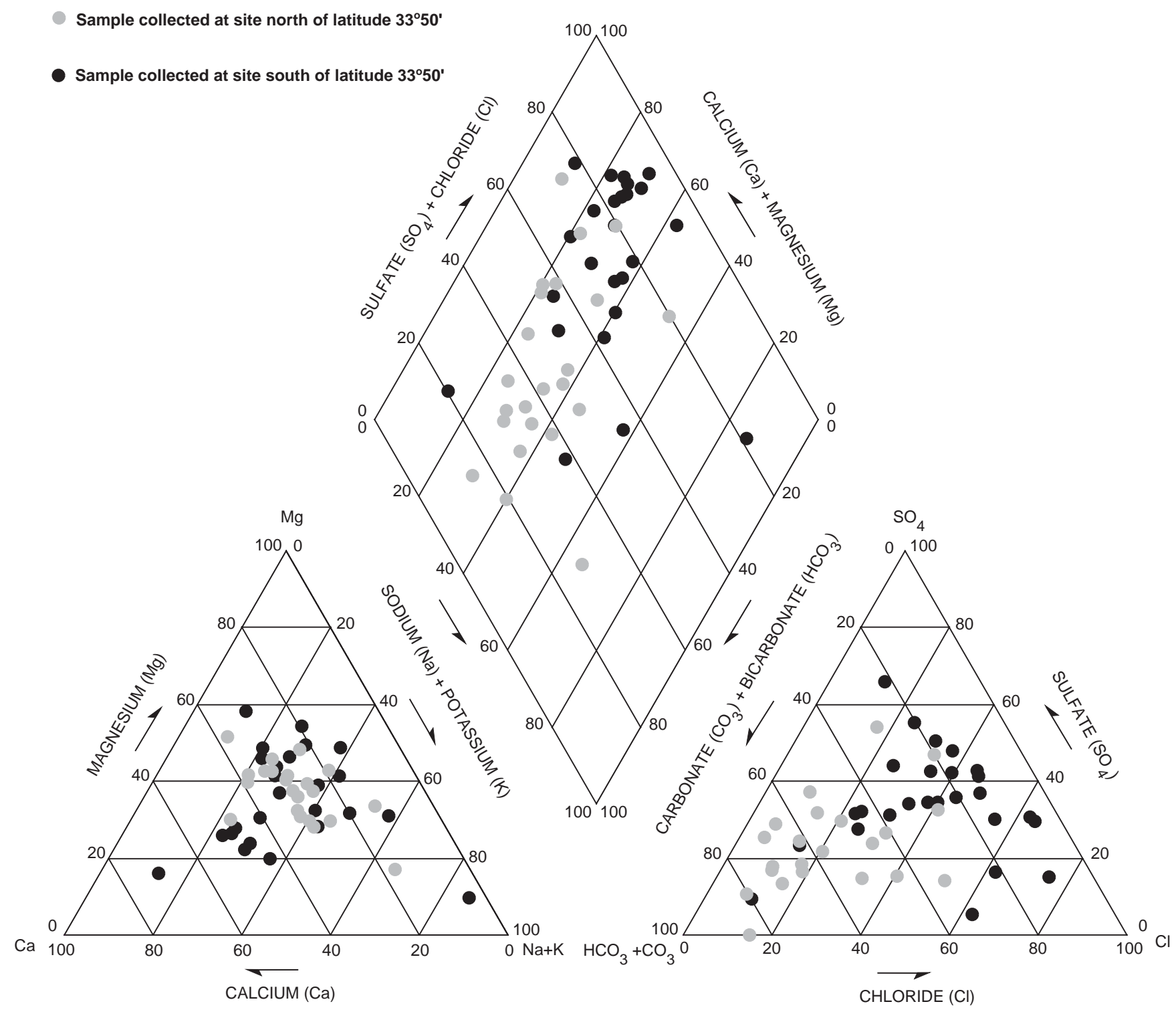

CATIONS

ANIONS

\section{PERCENT MILLIEQUIVALENTS}

Figure 6. Trilinear diagram showing the relations between concentrations of major ions in water sampled from primarily domestic wells screened in the southern High Plains aquifer, Texas and New Mexico, 2001.

16.9 to $603 \mathrm{mg} / \mathrm{L}$, and the median was $89.4 \mathrm{mg} / \mathrm{L}$. Concentrations in 11 samples were larger than $250 \mathrm{mg} / \mathrm{L}$.

Fluoride is another major ion that often is present in natural waters. Fluoride is desirable for healthy development of bones and teeth, but in large concentrations it can be detrimental to health. Large exposures to fluoride might cause lung, skin, and bone damage (Agency for Toxic Substances and Disease Registry, 2002). Fluoride concentrations ranged from 0.4 to
$8.3 \mathrm{mg} / \mathrm{L}$, and the median among 48 samples was $2.4 \mathrm{mg} / \mathrm{L}$. Concentrations in 14 samples were at least $2.0 \mathrm{mg} / \mathrm{L}$ but less than $4.0 \mathrm{mg} / \mathrm{L} ; 2.0 \mathrm{mg} / \mathrm{L}$ is the USEPA SMCL for fluoride. Concentrations in 16 samples were $4.0 \mathrm{mg} / \mathrm{L}$ (USEPA MCL) or larger. Figure 8 shows the distribution of fluoride concentration in samples collected. Most of the samples that had large fluoride concentrations were in the southern part of the study area, but three were in the northeast. 


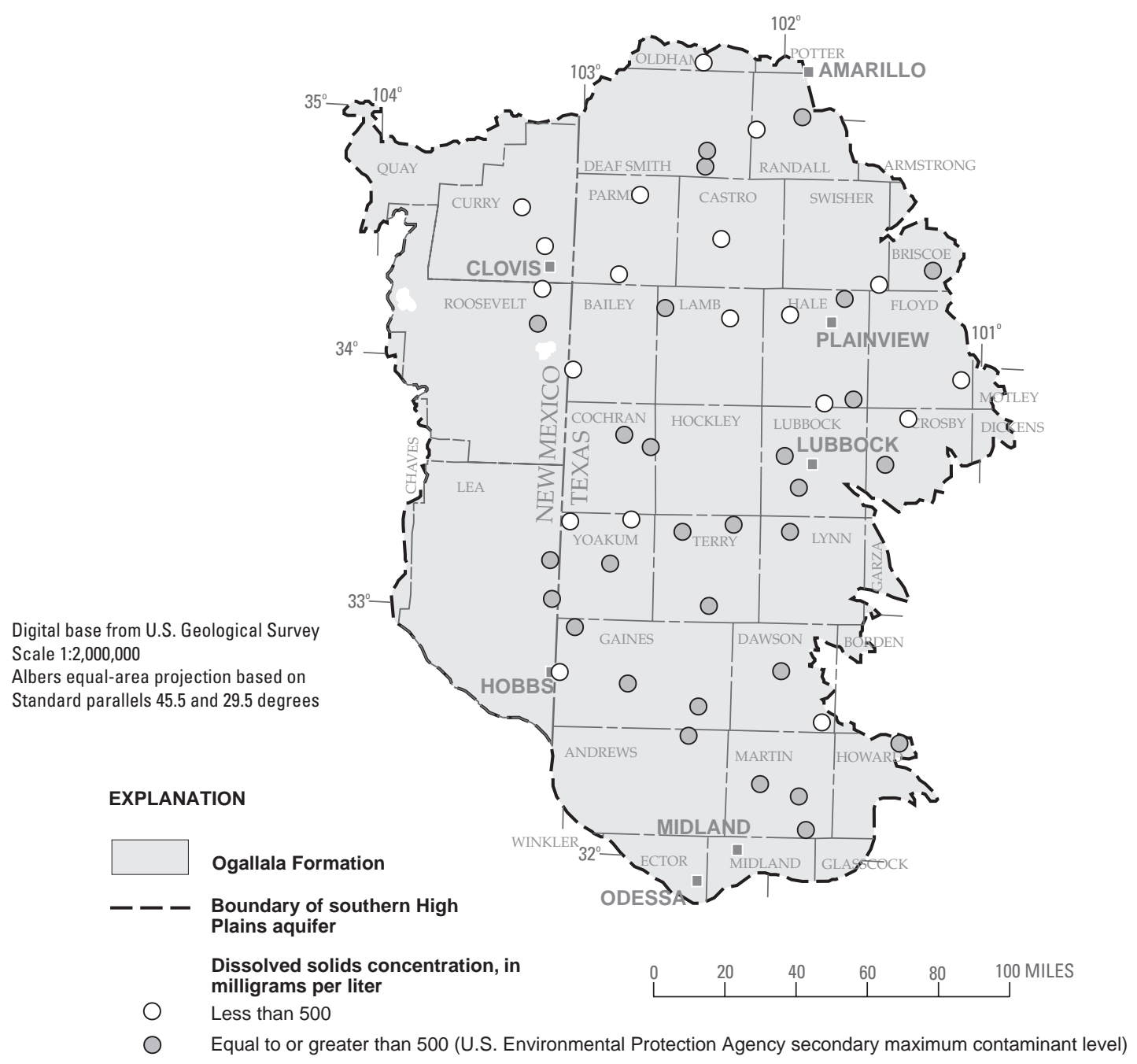

Figure 7. Dissolved solids concentrations in water sampled from primarily domestic wells screened in the southern High Plains aquifer, Texas and New Mexico, 2001.

\section{Nutrients and Dissolved Organic Carbon}

Nitrogen, phosphorus, and carbon compounds are essential to the health of plants and animals. Elevated concentrations of nutrients (nitrogen compounds in water), however, can cause health problems in humans. A USEPA MCL of $10.0 \mathrm{mg} / \mathrm{L}$ nitrate, reported as nitrogen, has been established because of potential adverse health effects on humans, particularly infants. Nitrogen and phosphorus occur naturally in water, but natural concentrations can be increased by human activities. Factors that might affect nitrate concentrations in ground water include the proximity of wells to septic systems, livestock operations, and locations where fertilizers and manure are stored and applied, as well as intensity of irrigation, amount of precipitation, soil characteristics, topography, and presence or absence of impermeable layers above the aquifer. After examining nutrient data from natural settings across the country, the U.S. Geological Survey (1999) estimated a national average concentration of naturally occurring nitrate (sum of nitrate plus nitrite; contribution of nitrite to sum commonly is negligible) in ground water of $2.0 \mathrm{mg} / \mathrm{L}$, reported as nitrogen. That study indicated that nitrate concentrations larger than $2.0 \mathrm{mg} / \mathrm{L}$ might be related to human activities. However, McMahon (2001) suggests that the background concentration for nitrate in ground water might be somewhat larger, $2.5 \mathrm{mg} / \mathrm{L}$, for the central High Plains aquifer. Using the background nitrate 


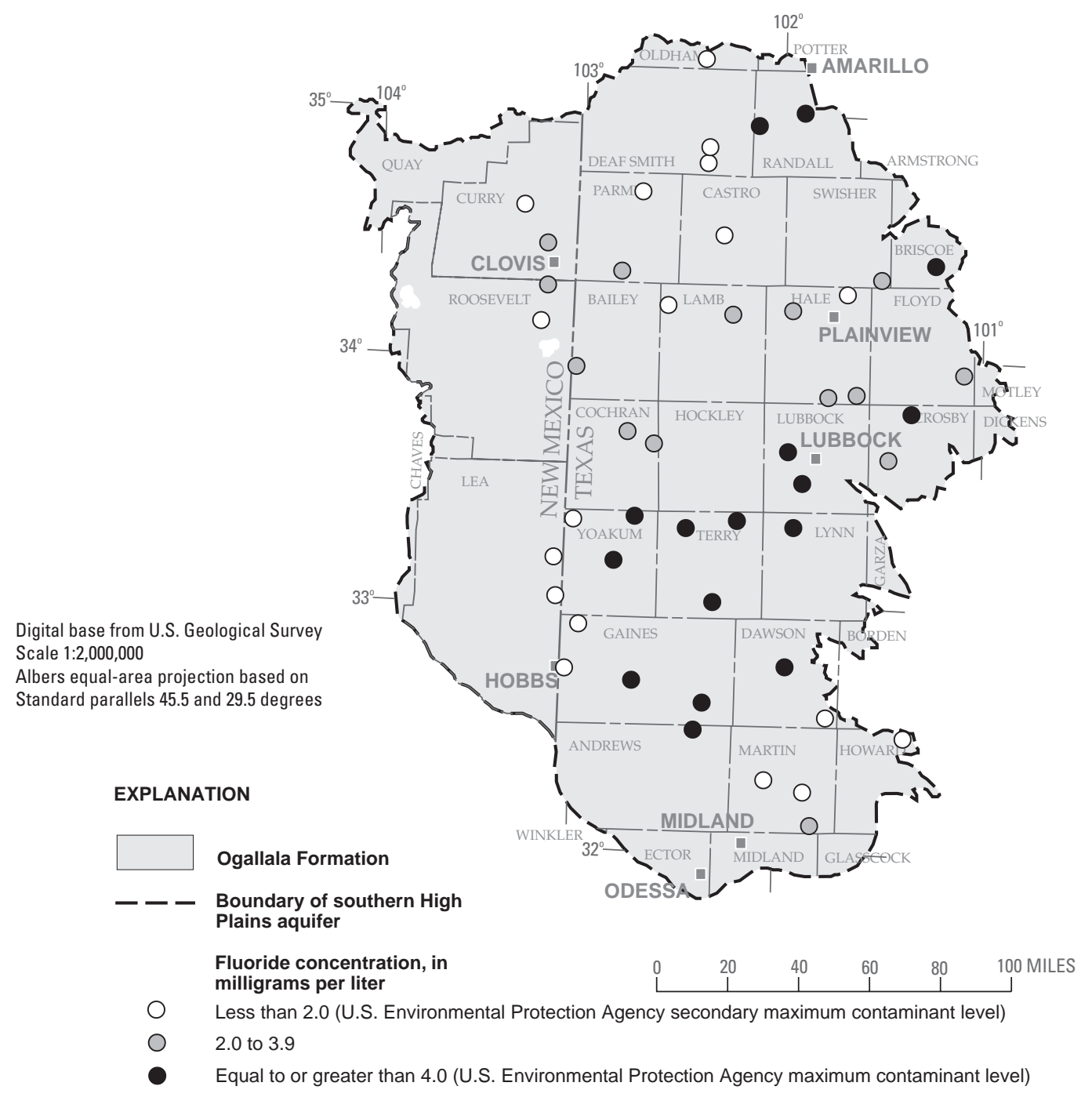

Figure 8. Fluoride concentrations in water sampled from primarily domestic wells screened in the southern High Plains aquifer, Texas and New Mexico, 2001.

concentration reported by McMahon, concentrations of nitrate in the southern High Plains aquifer less than $2.5 \mathrm{mg} / \mathrm{L}$ probably are natural, and concentrations larger than $2.5 \mathrm{mg} / \mathrm{L}$ might result from human activities. Appendix 3 lists concentrations of nutrients and DOC in samples collected during this study.

Thirteen of 48 samples contained ammonia plus organic nitrogen. Because ammonia, analyzed separately, was not detected in any samples, all of the nitrogen in these samples is in the form of organic nitrogen, that is, nitrogen derived from organic matter. Concentrations ranged from 0.11 to $0.31 \mathrm{mg} / \mathrm{L}$, with a median concentration of $0.13 \mathrm{mg} / \mathrm{L}$. Nitrite was measured in only one sample at a very small concentration of
$0.012 \mathrm{mg} / \mathrm{L}$. Nitrate was detected in all samples. Nitrate concentrations ranged from 0.179 to $19.5 \mathrm{mg} / \mathrm{L}$, with a median concentration of $2.98 \mathrm{mg} / \mathrm{L}$. Figure 9 shows the distribution of nitrate samples collected and the concentration ranges measured. Concentrations in 21 samples were less than a threshold value of $2.5 \mathrm{mg} / \mathrm{L}$; concentrations in 21 samples were at least $2.5 \mathrm{mg} / \mathrm{L}$ but less than $10.0 \mathrm{mg} / \mathrm{L}$; and concentrations in six samples were $10 \mathrm{mg} / \mathrm{L}$ (USEPA MCL) or larger. Sites with nitrate concentrations larger than the threshold value of $2.5 \mathrm{mg} / \mathrm{L}$ were located throughout the study area.

Dissolved orthophosphate (reported as phosphorus) concentrations for two samples were 0.025 and $0.038 \mathrm{mg} / \mathrm{L}$. Dissolved phosphorus was measured in 


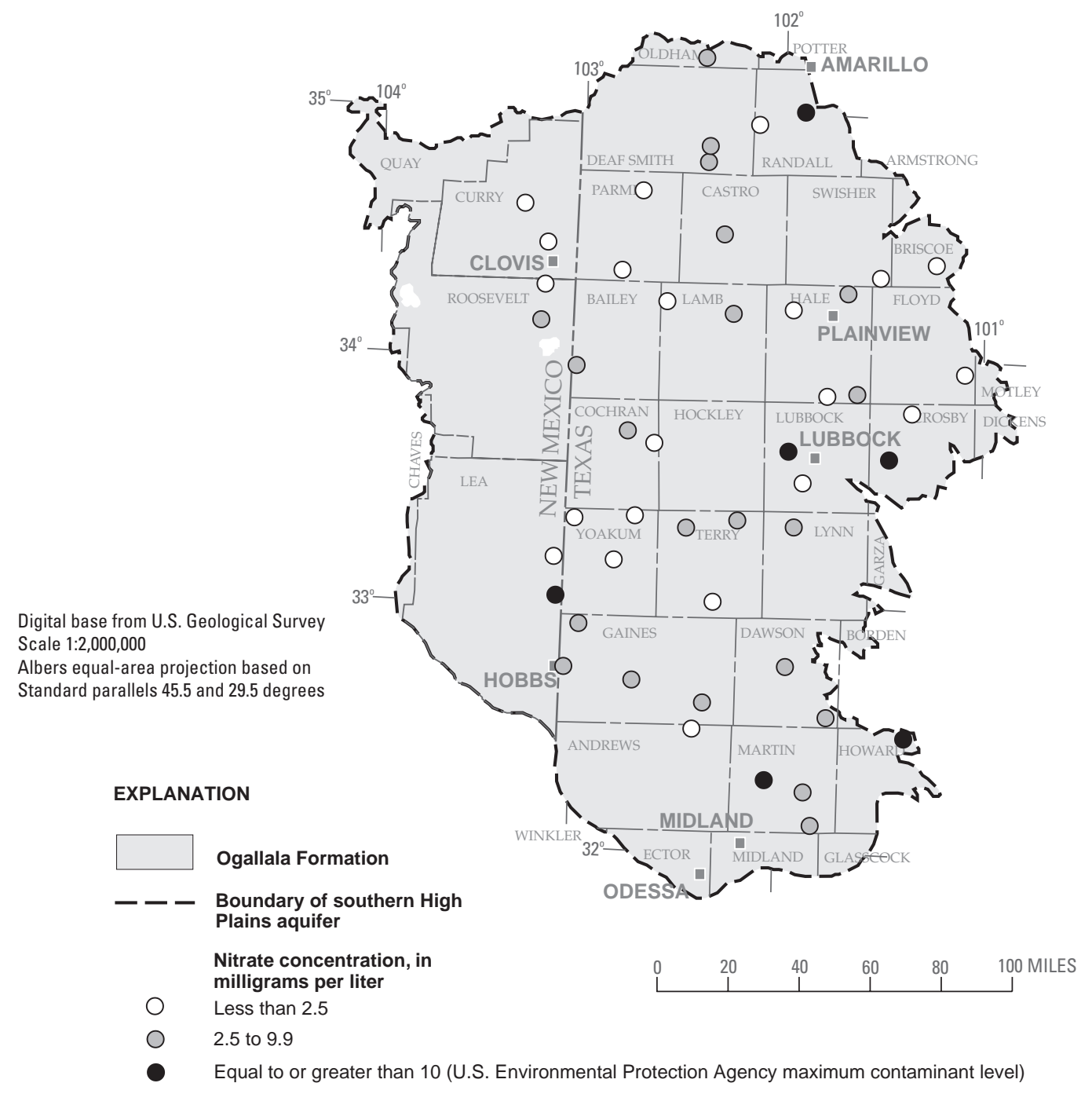

Figure 9. Nitrate concentrations in water sampled from primarily domestic wells screened in the southern High Plains aquifer, Texas and New Mexico, 2001.

one-fourth (12) of the samples. Concentrations were small and ranged from 0.007 to $0.047 \mathrm{mg} / \mathrm{L}$, with a median concentration of $0.0095 \mathrm{mg} / \mathrm{L}$.

Most natural ground waters contain small concentrations of DOC. In the absence of organic contamination such as landfill leachate or petroleum spills, the source of DOC in ground water likely is the result of the breakdown of organic matter in soil. If present in large enough quantities, organic solutes composing DOC might form complexes that affect trace element solubility, participate in oxidation-reduction reactions, and affect physical and chemical properties of solid-liquid or liquid-gas interfaces (Hem, 1985). No drinking-water standard has been established for DOC. Dissolved organic carbon was detected in 38 of 47 samples analyzed, and concentrations ranged from about 0.37 to $3.4 \mathrm{mg} / \mathrm{L}$, with a median of $1.0 \mathrm{mg} / \mathrm{L}$.

Compounds containing nitrogen and phosphorus, such as synthetic fertilizers and manure, commonly are applied to cropland and pastures to stimulate plant growth and increase yield. Synthetic fertilizers include anhydrous ammonia, ammonium nitrate, urea, and mono- and diammonium phosphates. Livestock also produce large quantities of phosphorus- and nitrogenrich organic wastes. Other sources of nutrients include human and industrial waste. In the southern High Plains the likely sources of elevated nitrate to rural domestic wells are septic systems, fertilizer, and livestock. Five 
counties with the most livestock in the study area (U.S. Department of Agriculture, 2002b) are Deaf Smith (485,000 head), Castro $(340,000)$, Parmer $(292,000)$, Swisher $(143,000)$, and Hale $(105,000)$. In 1998, about 448 million pounds (lb) of fertilizer containing nitrogen was applied to the southern High Plains (D.L. Lorenz, U.S. Geological Survey, written commun., 1999). Five counties in the study area where the most nitrogen fertilizer was applied in 1998 were Gaines (about 5.4 million lb), Hale (about 3.8 million lb), Parmer (about 3.5 million $\mathrm{lb}$ ), Terry and Castro (about 3.1 million $\mathrm{lb}$ each). Assuming nitrogen application rates do not vary much over time and space, the six samples that had nitrate concentrations greater than $10 \mathrm{mg} / \mathrm{L}$ were widely distributed in the study area and do not appear to be correlated with counties that had the highest nitrogen application rates or with counties having the most livestock.

\section{Trace Elements}

Most trace elements are essential to living things in minute quantities; however, very small increases in concentrations might cause beneficial amounts to be exceeded. Generally, trace elements occur naturally in water in small concentrations (much less than $1 \mathrm{mg} / \mathrm{L}$ ) and result from water interacting with surrounding geological deposits. Even though some trace elements are quite common, they might not be detected in water. For example, aluminum is one of the most abundant elements in rocks, yet it rarely occurs in concentrations greater than a few hundred micrograms per liter in natural ground waters (Hem, 1985). In addition to natural sources, there are anthropogenic sources of trace elements such as fossil fuels, paints and corrosion inhibitors, construction and plumbing materials, and pesticides, to name a few. Wide natural and anthropogenic distribution of trace elements creates the possibility for occurrence, or increased occurrence, of some trace elements in water. Except for selenium, the 23 trace elements analyzed in 47 water samples were metals and metalloids (appendix 4).

Trace elements detected in all 47 of the samples were arsenic, barium, boron, cobalt, lithium, molybdenum, selenium, strontium, uranium, and vanadium. Copper was detected in 45 samples, zinc in 42 samples, manganese in 14 samples, and lead in 12 samples. Nickel was detected in five samples, and aluminum, cadmium, chromium, and iron were detected once each. Antimony, beryllium, silver, and thallium were not detected in any samples.
Measured concentrations of trace elements were quite variable (appendix 4 and table 2) and less than established public drinking-water standards or guidelines for most elements. Public drinking-water standards or guidelines have not been established for cobalt, lithium, and vanadium. Figure 5 shows the concentrations of selected trace elements relative to public drinking-water standards or guidelines. Eight samples had strontium concentrations equal to or greater than the non-enforceable USEPA HA or MCLG of 4,000 micrograms per liter $(\mu \mathrm{g} / \mathrm{L})$; five samples had boron concentrations larger than the USEPA HA of $600 \mu \mathrm{g} / \mathrm{L}$, and four samples had manganese concentrations larger than the USEPA HA of $50 \mu \mathrm{g} / \mathrm{L}$. Fourteen arsenic samples also exceeded the new (2002) USEPA MCL of $10 \mu \mathrm{g} / \mathrm{L}$. Potential health effects from excessive arsenic concentrations in drinking water include cardiovascular disease, diabetes, anemia, and an increased risk of cancer (U.S. Environmental Protection Agency, 2000). Arsenic can occur naturally in rocks, particularly sulfides, and is associated with iron oxides on mineral surfaces. Anthropogenic sources of arsenic in the study area include wood preservatives, pesticides, feed additives for poultry and swine, and petroleum products (Welch and others, 2000). In the southern High Plains, arsenic concentrations ranged from 1.7 to $107 \mu \mathrm{g} / \mathrm{L}$, with a median concentration of $6.5 \mu \mathrm{g} / \mathrm{L}$. All 14 samples that had concentrations larger than the USEPA MCL were collected in the southern part of the study area (fig. 10). Although it has been suggested that the source of arsenic in the southern High Plains might be pesticide applications (Hudak, 2000), other sources are possible. In the study area, other factors that might affect the concentration of arsenic include subsurface geology, for example dark, organic-rich Cretaceous shale or volcanic ash; shallow saline lakes with large evaporation rates; and oilfield brines (A.H. Welch, U.S. Geological Survey, oral commun., 2002).

\section{Radon}

Radon is a colorless, odorless, radioactive gas that forms naturally from radioactive decay of uranium in rocks (Alley, 1993). Ground water in contact with rocks that contain uranium might contain elevated concentrations of radon. Radon dissolved in water generally poses a smaller health risk than radon in indoor air, which has been linked to lung cancer in humans (U.S. Environmental Protection Agency, 1999). About 1 to 2 percent of radon in indoor air might come from drinking 


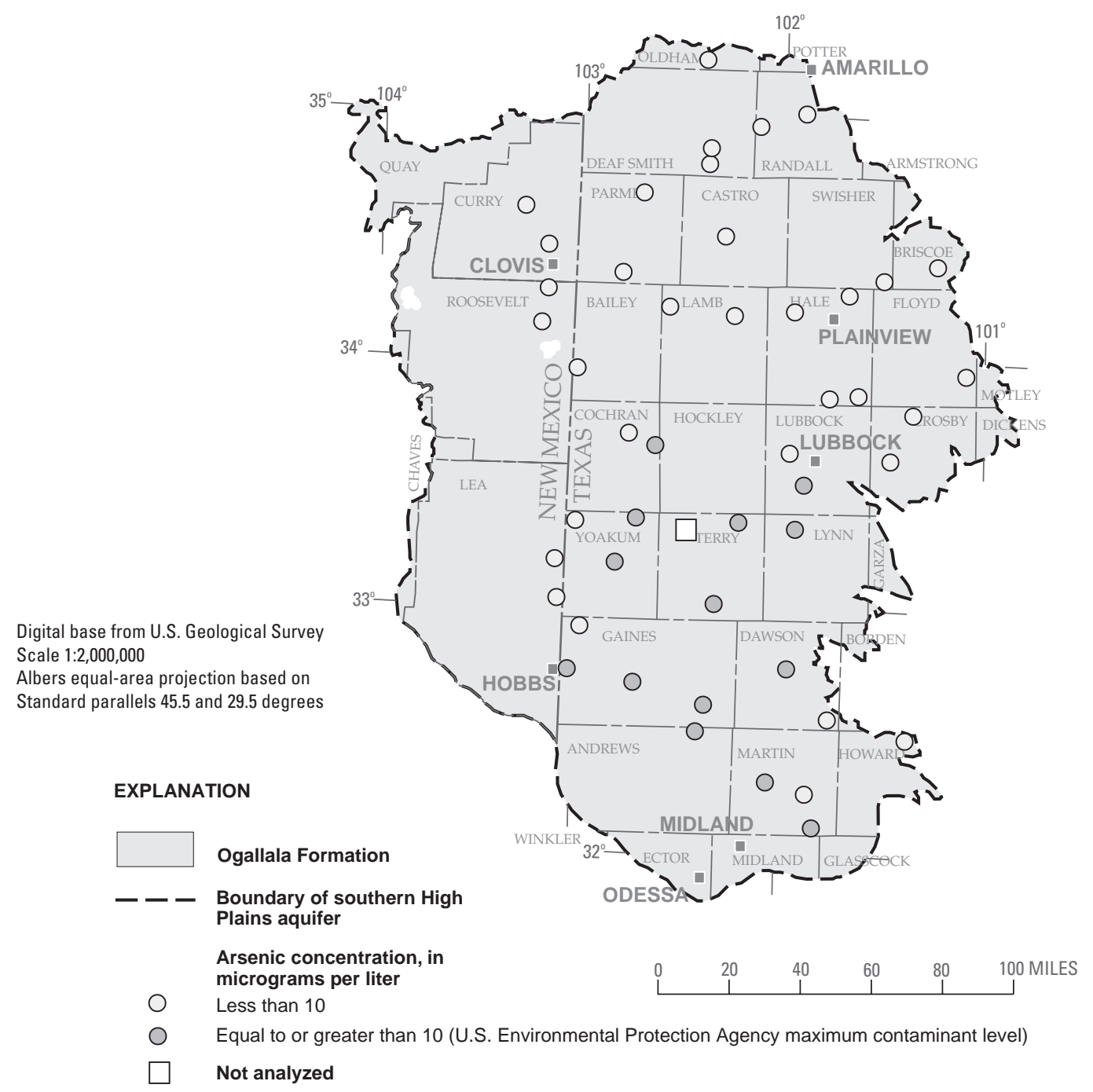

Figure 10. Arsenic concentrations in water sampled from primarily domestic wells screened in the southern High Plains aquifer, Texas and New Mexico, 2001.

water. The USEPA has proposed two standards for radon in public drinking water: an MCL of 300 picocuries per liter ( $\mathrm{pCi} / \mathrm{L}$ ) and an alternative $\mathrm{MCL}$ of 4,000 $\mathrm{pCi} / \mathrm{L}$ when there is a mitigation program, usually for public supply wells, to address radon risks in indoor air. Radon was detected in all 46 samples analyzed, and concentrations (technically, "radioactivities") ranged from 202 to $1,440 \mathrm{pCi} / \mathrm{L}$ (appendix 5), with a median of $428 \mathrm{pCi} / \mathrm{L}$ (table 2). Thirty-six samples had radon concentrations greater than the lower proposed standard (fig. 5), and these samples were widely distributed over the study area (fig. 11). No concentration exceeded the higher proposed standard of 4,000 pCi/L. Similar obser- vations of radon occurrence in the southern High Plains aquifer were made by Hughes (1994).

\section{Pesticide Compounds}

The widespread use of pesticides since World War II in all landscape settings creates the potential for movement of pesticides and their breakdown products into ground water. In sufficiently large concentrations or prolonged exposure, pesticides can cause health problems that include kidney and nerve damage and cancer (U.S. Environmental Protection Agency, 1989). One-hundred six pesticide compounds from classes of herbicides, insecticides, and fungicides that include 


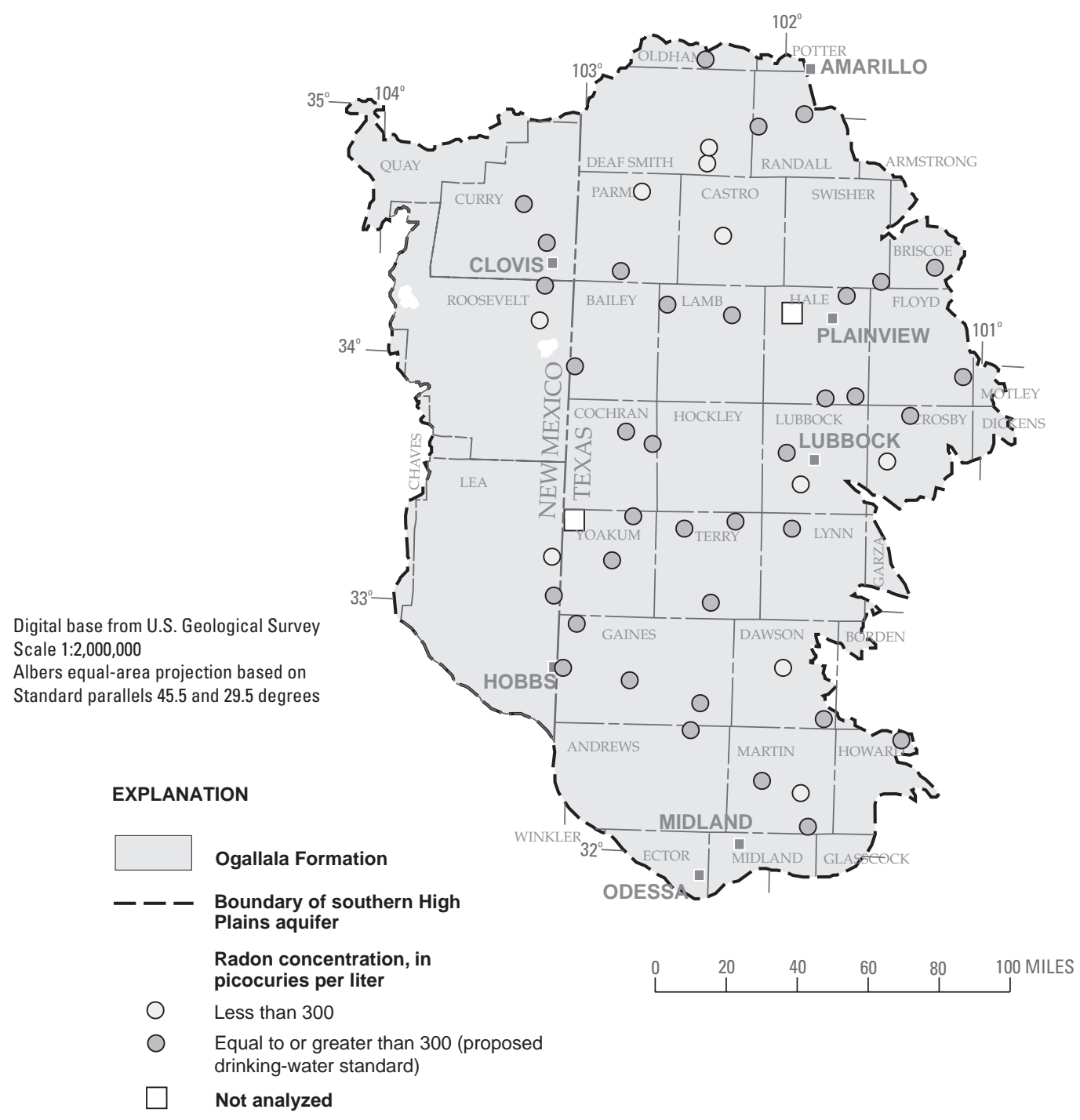

Figure 11. Radon concentrations in water sampled from primarily domestic wells screened in the southern High Plains aquifer, Texas and New Mexico, 2001.

triazines, organophosphorus compounds, organochlorines, and carbamates, among others, were analyzed.

Pesticide compounds were detected in less than 20 percent (eight) of the samples (appendix 6). Five samples with detections were from sites in the northern part of the study area, and three samples with detections were from sites in the southern part (fig. 12). All detections were at very small concentrations of less than $0.24 \mu \mathrm{g} / \mathrm{L}$. Of the 106 pesticide compounds analyzed, eight were detected: atrazine and four atrazine breakdown products, dacthal mono-acid (breakdown product of dacthal), dicamba, and malathion. Malathion is an insecticide, and the others are herbicides. Two samples contained three pesticides, three samples contained two pesticides, and three samples contained one pesticide. Atrazine and deethylatrazine were the most frequently detected compounds, at five and four detections, respectively. Concentrations ranged from 0.011 to $0.115 \mu \mathrm{g} / \mathrm{L}$ for atrazine and from 0.037 to $0.234 \mu \mathrm{g} / \mathrm{L}$ for deethylatrazine. Additional atrazine breakdown products detected in one sample each were deethyldeisopropylatrazine $(0.02 \mu \mathrm{g} / \mathrm{L})$, deisopropylatrazine $(0.06 \mu \mathrm{g} / \mathrm{L})$, and 2-hydroxyatrazine $(0.012 \mu \mathrm{g} / \mathrm{L})$. The concentrations of other pesticides detected were $0.04 \mu \mathrm{g} / \mathrm{L}$ dacthal mono-acid (breakdown product), $0.02 \mu \mathrm{g} / \mathrm{L}$ dicamba, and $0.029 \mu \mathrm{g} / \mathrm{L}$ malathion. Concentrations of atrazine were substantially less than the USEPA MCL of $3.0 \mu \mathrm{g} / \mathrm{L}$. MCLs have not been established for the 


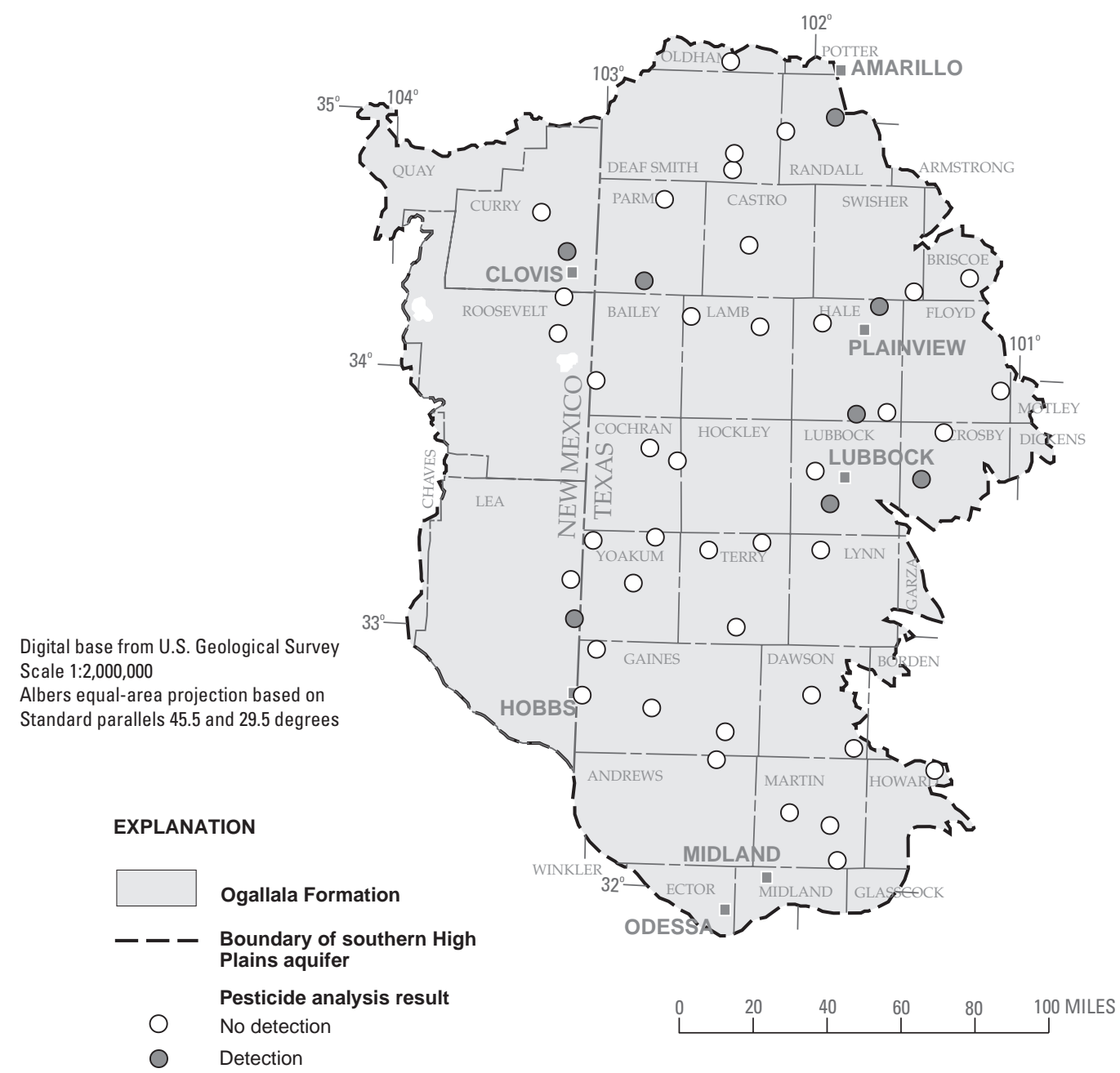

Figure 12. Pesticide analysis results in water sampled from primarily domestic wells screened in the southern High Plains aquifer, Texas and New Mexico, 2001.

other pesticide compounds detected in this study. Evaluation of QC data indicates that actual concentration probably was considerably less than the reported concentration for 2-hydroxyatrazine. Actual concentrations of atrazine, deisopropylatrazine, and deethyldeisopropylatrazine probably were less than reported concentrations. Actual concentrations of dacthal monoacid and dicamba probably were the same as reported concentrations. Actual concentrations of deethylatrazine and malathion probably were more than reported concentrations.

In 1992 in the southern High Plains, atrazine was the most abundantly applied pesticide at $914,765 \mathrm{lb}$, weighted to the percent of county within the study area (G.P. Thelin, U.S. Geological Survey, written commun., 1998). Atrazine is classified as a restricted use pesticide
(Extension Toxicology Network, 1996). The other pesticides detected are classified as general use pesticides. Atrazine and dicamba are used on corn and sorghum. The pesticides detected have been available for home and garden use as well as for agricultural use (Barbash and Resek, 1996).

Nationally, some of the most commonly detected pesticide compounds in ground water are atrazine and deethylatrazine (U.S. Geological Survey, 1999), similar to findings in the southern High Plains. For comparison, pesticides have been found in one-third of water samples collected from 68 major aquifers studied by NAWQA across the Nation, regardless of landscape (Gilliom, 2001). Other pesticides that have been frequently detected nationally are metolachlor, prometon, and simazine. Metolachlor was one of the most 


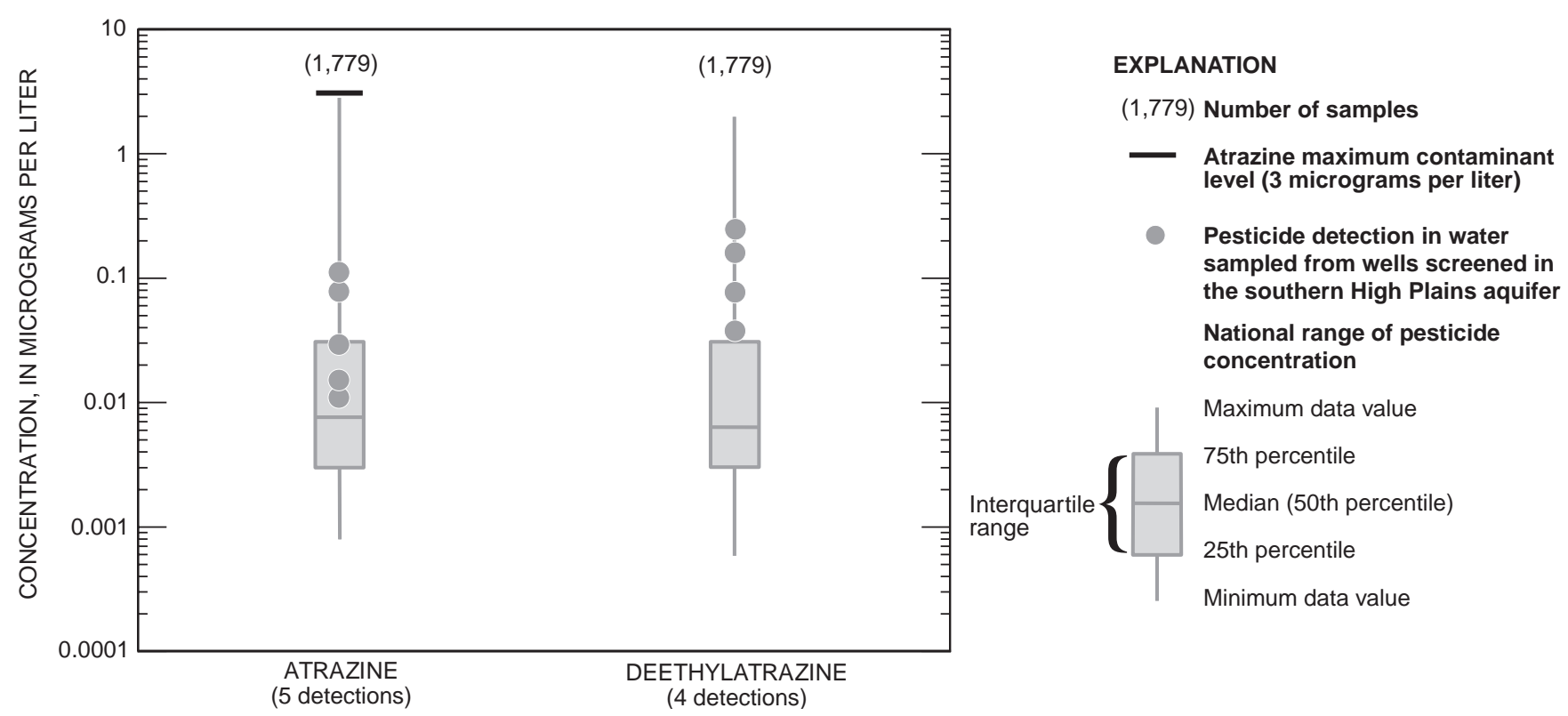

Figure 13. Pesticide concentrations, relative to the national range, in water sampled from primarily domestic wells screened in the southern High Plains aquifer, Texas and New Mexico, 2001.

frequently used pesticides in the southern High Plains in 1992, yet it was not detected in this study. The percentage of detections and small concentrations of pesticides measured in the southern High Plains water samples, particularly atrazine and deethylatrazine, are similar to national findings (K.A. Skach, U.S. Geological Survey, written commun., 2002). Figure 13 shows that three of the five concentrations of atrazine detected in the southern High Plains are within the middle 50th percentile of the national range of concentrations measured by the USGS. However, deethylatrazine concentrations were above the 75th percentile of the national range. Although samples for both pesticides have concentrations larger than the 75th percentile, concentrations are much smaller than the maximum detected concentrations for these same pesticides in major aquifers studied by NAWQA across the Nation.

\section{Volatile Organic Compounds}

VOCs are a group of relatively low molecular weight hydrocarbons that have high aqueous solubility and might be resistant to degradation. VOCs are ubiquitous; they are by-products or components in the production of fuels, lubricants, food, drugs, paints and varnishes, deodorants, pesticides, fumigants, refrigerants, glues and adhesives, rubber, cleaning agents, degreasers, disinfectants, dyes, perfumes, and many other materials. Some VOCs might occur naturally. The presence of one or more VOCs in ground water might pose a health concern. In sufficiently large concentrations or prolonged exposure, VOCs can cause health problems that include liver, kidney, and nerve damage and cancer (U.S. Environmental Protection Agency, 2000).

Water samples from 47 of the 48 wells sampled in the southern High Plains aquifer were analyzed for 85 VOCs (appendix 7). Of the 85 VOCs analyzed, four VOCs were detected in six water samples. There were four detections of trichloromethane (chloroform) (range 0.05 to $1.51 \mu \mathrm{g} / \mathrm{L}$ ) and one detection each of tetrachloroethene (PCE) $(0.5 \mu \mathrm{g} / \mathrm{L})$, tetrahydrofuran $(3 \mu \mathrm{g} / \mathrm{L})$, and methylethylketone $(10 \mu \mathrm{g} / \mathrm{L})$. One sample contained both tetrahydrofuran and methylethylketone. Trichloromethane is one of four trihalomethane (THM) compounds that form when chlorine disinfection products react with naturally occurring organic and inorganic matter in water. The current (2002) public drinkingwater standard for THMs in ground water is $100 \mu \mathrm{g} / \mathrm{L}$. Tetrachloroethene is a solvent that commonly is used in the dry cleaning industry or to remove organic residues (Agency for Toxic Substances and Disease Registry, 2002). Tetrachloroethene can be leached from vinyl products such as polyvinyl chloride (PVC) pipe that commonly is used in the construction of ground-water 
wells. The USEPA MCL for tetrachloroethene is $5.0 \mu \mathrm{g} / \mathrm{L}$. Tetrahydrofuran and methylethylketone are in many household products such as lacquers, glues, varnishes, and paint remover. The suggested USEPA lifetime drinking water equivalent level for methylethylketone is $20 \mathrm{mg} / \mathrm{L}$. Trichloromethane detected in this study might have come from disinfection or from leaking septic systems, common sources of this compound in rural domestic water samples (Moran and others, 2002). The other three compounds detected might have resulted from desorption or leaching from PVC pipe or glue used for construction and plumbing of wells.

Tetrachloroethene and trichloromethane are two of the most frequently detected VOCs in USGS NAWQA aquifer studies across the Nation (Moran and others, 2002). Compounds detected did not exceed public drinking-water standards or guidelines. Evaluation of QC data indicates that actual concentrations of trichloromethane, tetrachloroethene, and tetrahydrofuran probably are nearly the same as reported concentrations. Methylethylketone was not evaluated. In the absence of QC data for methylethylketone, the assumption is that the actual concentration is the same as the measured concentration.

\section{Tritium}

About one-third of the water samples showed no evidence (nitrate concentration larger than the threshold value of $2.5 \mathrm{mg} / \mathrm{L}$ or pesticide detection) of recent (less than about 50 years) ground water. Tritium was analyzed in these samples to indicate relative age of ground water (appendix 5). Tritium is a radioactive isotope of hydrogen and exists naturally in the environment in small concentrations. Tritium concentrations in the atmosphere increased during atmospheric nuclear tests of the 1950s and early 1960s. Since 1964, nuclear tests have been conducted underground, and anthropogenic tritium no longer has been added to the atmosphere. Tritium in the atmosphere travels with precipitation that falls on the land surface. In the southern High Plains, most precipitation evaporates, but some might percolate below the land surface to recharge the aquifer. Anthropogenically increased concentrations of tritium frequently have been used as an indicator of recently recharged ground water, although this application is rapidly waning as the radioactive tritium molecules decay through time. At the time of sampling, tritium concentrations in ground water that were greater than
$1.6 \mathrm{pCi} / \mathrm{L}$ in the southern High Plains indicate that at least some of the ground water sampled was recharged within about the last 50 years. Two of the 16 samples analyzed contained measurable tritium, 3.2 and 6.1 $\mathrm{pCi} / \mathrm{L}$ (table 2), which indicates that some fraction of water sampled at these two sites is recently recharged ground water.

Figure 14 illustrates locations of sites with one or more indicators of young ground water, as indicated by nitrate concentration larger than $2.5 \mathrm{mg} / \mathrm{L}$, detection of pesticide, or tritium concentration larger than $1.6 \mathrm{pCi} / \mathrm{L}$. These indicators provide evidence that at least some of the water that was sampled has come in contact with a constituent that has been introduced to the land surface in about the last 50 years. About 70 percent (33) of the water samples contained at least one indicator of young age; those sites were distributed throughout the study area. Four sites had two indicators of young ground water, nitrate concentration larger than $2.5 \mathrm{mg} / \mathrm{L}$ and at least one pesticide detection.

\section{WATER-QUALITY DATA FOR AGRICULTURAL USES}

The primary focus of this report is to present chemical data in the context of drinking-water quality; however, the data also can be evaluated with regard to agricultural applications. Water-quality information collected for this study also can be useful to farmers near these sampling sites. Bruce and Oelsner (2001) demonstrated that naturally occurring inorganic constituents, major ions and trace elements, in small-capacity domestic wells drilled into the High Plains aquifer in the central High Plains occur at similar concentrations in nearby large-capacity public supply wells. Given the similarity in construction between public supply wells and irrigation wells in the southern High Plains, inorganic water-quality constituents from the domestic wells probably are similar in concentration to those of nearby irrigation wells that are screened in the same interval of the southern High Plains aquifer. In such cases, chemical information from the samples of this study might be used to infer quality of water used for irrigation.

Knowing salinity of the water is important in irrigation because excess salts can be harmful to crops, especially salt-sensitive crops. Also, excessive dissolved solids, particularly those that contribute to hardness, can clog emitters used in micro-irrigation equipment. Risks can be overcome through proper 
Digital base from U.S. Geological Survey Scale 1:2,000,000

Albers equal-area projection based on Standard parallels 45.5 and 29.5 degrees

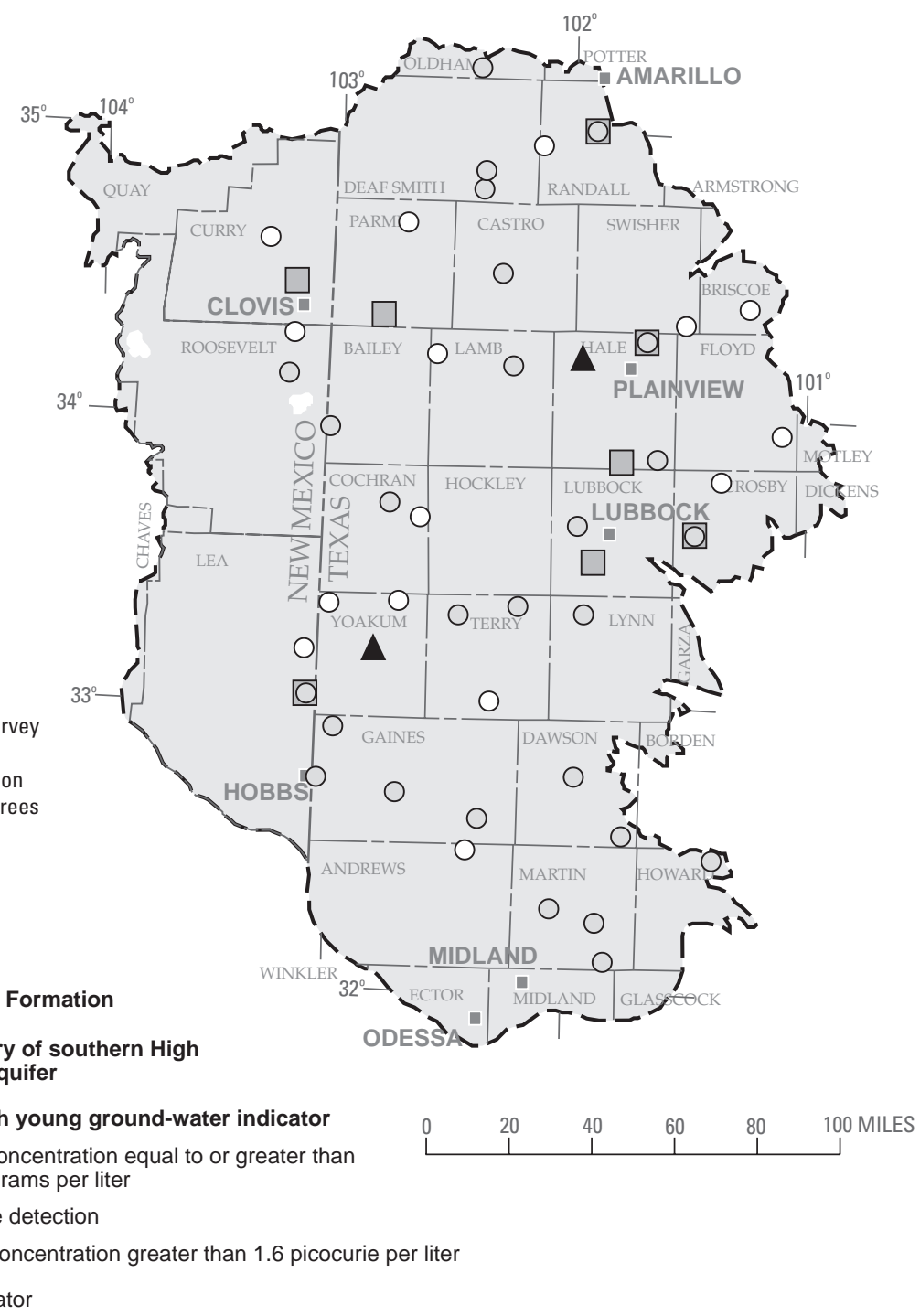

Figure 14. Location of sites with one or more indicators of young (approximately less than 50 years) ground water determined from water samples collected from primarily domestic wells screened in the southern High Plains aquifer, Texas and New Mexico, 2001.

maintenance, but knowing the risk is important for determining proper action. Salinity can be inferred from either specific conductance or dissolved solids concentration data. For example, conductance larger than 2,000 to $3,000 \mu \mathrm{S} / \mathrm{cm}$, or dissolved solids greater than 1,400 to $2,100 \mathrm{mg} / \mathrm{L}$ (parts per million), is considered excessive for most crops (Quiring and Pennington, 1989; Fipps, 1996). Dissolved solids concentrations of four samples were greater than $1,400 \mathrm{mg} / \mathrm{L}$ (appendix 2). Water-quality data also can be examined to identify possible sources of salinity. Nativ (1988) reported pos- sible sources of salinity to the southern High Plains aquifer are underlying Cretaceous and Permian sediments, saline lakes, and oilfield brines.

Parameters, such as sodium adsorption ratio (SAR) and soluble sodium percentage (SSP), can be computed from major ion data (appendix 2). Table 2 lists the ranges for these computed values. SAR is an indicator of the relative risk that a soil might become sodic (increase in sodium concentration) and is computed as the ratio of sodium concentration to the sum of calcium and magnesium concentrations 
(concentrations, in milliequivalents per liter). At high concentrations relative to calcium and magnesium, sodium adsorbed to soil particles might contribute to dispersion of soil aggregates. This dispersion breaks down soil structure and can make soil less permeable to water. Although sodium does not harm plants directly, it can reduce the amount of water available to crops. A

SAR larger than 9 for irrigation water increases the risk of high soil SAR (greater than 13). Computed SARs (in water) ranged from 0.4 to 16 , and the median was 1 . One sample had a SAR larger than 9. SSP also is used to evaluate sodium hazard. SSP is the ratio of sodium concentration to the sum of cation concentrations (in milliequivalents per liter), multiplied by 100 . Water with SSP larger than 60 might result in increased sodium concentration in soil (Fipps, 1996). Computed SSPs ranged from 8.8 to 85.0 , with a median of 28.8 . SSPs were larger than 60 in two samples.

Some constituents might be important micronutrients for crops, particularly sodium, chloride, and boron (Fipps, 1996). However, toxicity can be a risk for crops when constituent concentrations are large or increase over time. Major ion and trace element concentrations (appendixes 2,4) can be examined with regard to specific crop and livestock needs. For example boron is toxic to peanuts at concentrations greater than 670 $\mu \mathrm{g} / \mathrm{L}$. Boron concentrations were larger than $670 \mu \mathrm{g} / \mathrm{L}$ in four samples (appendix 4). Selenium is toxic to some plants at concentrations greater than $20 \mu \mathrm{g} / \mathrm{L}$. Selenium concentrations were larger than $20 \mu \mathrm{g} / \mathrm{L}$ in six samples. Sites where water quality might be of concern to agricultural interests are in the southern part of the study area. These data also might be evaluated with regard to livestock needs if livestock consume water from nearby wells completed in the same interval of the aquifer or if they consume vegetation irrigated with such waters.

\section{SUMMARY}

In the southern High Plains, water-quality information likely will become increasingly important as water levels decline. Knowledge of the quality of water resources is important because of implications for human and agricultural health in the region. Waterquality information, such as data generated by this study, can be useful for rural homeowners in determining what course of action to take, if any, regarding ground water used for domestic supply. Water-quality information also can be used to make decisions about agricultural practices.
In 2001, the USGS NAWQA Program collected water samples from 48 wells in the southern High Plains as part of a larger scientific effort to broadly characterize and understand factors affecting water quality of the High Plains aquifer across the entire High Plains. Water samples were collected primarily from domestic wells in Texas and eastern New Mexico. Depths of wells sampled ranged from 100 to $500 \mathrm{ft}$, with a median depth of $201 \mathrm{ft}$. Depths to water ranged from 34 to $445 \mathrm{ft}$ below land surface, with a median depth of $134 \mathrm{ft}$.

Concentrations of dissolved solids, a measure of the sum of dissolved ions, were larger than the esthetic public drinking-water guideline of $500 \mathrm{mg} / \mathrm{L}$ in 29 of 48 samples distributed throughout the study area. Calcium and magnesium ion concentrations contributed substantially to hardness of water. All but one of the samples were categorized as hard, that is, having concentrations larger than $120 \mathrm{mg} / \mathrm{L}$, summed as calcium carbonate. Chloride and sulfate concentrations were greater than the esthetic public drinking-water guideline of 250 $\mathrm{mg} / \mathrm{L}$ in seven and 11 samples, respectively. Fluoride concentrations in 14 samples were at least $2 \mathrm{mg} / \mathrm{L}$, the esthetic public drinking-water guideline, but less than $4 \mathrm{mg} / \mathrm{L}$; concentrations in 16 samples were $4 \mathrm{mg} / \mathrm{L}$, the public drinking-water standard, or larger. Most samples in which concentrations were larger than $4 \mathrm{mg} / \mathrm{L}$ were in the southern part of the study area; three samples were in the northeast.

Nitrate was detected in all samples. Nitrate was detected at concentrations larger than a threshold level of $2.5 \mathrm{mg} / \mathrm{L}$ in 27 of 48 samples; nitrate concentrations in six of the 27 samples were larger than the public drinking-water standard of $10 \mathrm{mg} / \mathrm{L}$. Sites with nitrate concentrations larger than $2.5 \mathrm{mg} / \mathrm{L}$ were distributed throughout the study area.

Arsenic was detected in all 47 samples, and 14 samples had concentrations that were larger than the new (2002) public drinking-water standard of $10 \mu \mathrm{g} / \mathrm{L}$. Strontium, boron, and manganese concentrations were greater than their respective drinking-water standard in eight, five, and four samples, respectively.

Radon was detected in all 46 samples, and concentrations in 36 samples were larger than the proposed public drinking-water standard of $300 \mathrm{pCi} / \mathrm{L}$. Samples with radon concentrations larger than the proposed standard were from sites throughout the study area.

Eight pesticide compounds (pesticides and their breakdown products) were detected at small concentrations (less than $0.24 \mu \mathrm{g} / \mathrm{L}$ ) in 8 of 48 samples. Five samples with detections were from sites in the 
northern part of the study area, and three samples with detections were from sites in the southern part. The most frequently detected pesticides were atrazine and atrazine breakdown products. Other pesticides detected once each were dacthal mono-acid, dicamba, and malathion. Evaluation of QC data for these lowlevel measurements indicates that actual concentrations probably were considerably less than reported concentrations for 2-hydroxyatrazine; about the same as reported concentrations for dacthal mono-acid and dicamba; somewhat less than reported concentrations for atrazine, deisopropylatrazine, and deethyldeisopropylatrazine; and more than reported concentrations for deethylatrazine and malathion. Although pesticides were detected in less than 20 percent of the samples collected in this study, both frequency of detection and range in concentrations are similar to observations made by USGS NAWQA aquifer studies conducted across the Nation, regardless of landscape.

Four of 85 VOCs analyzed - trichloromethane (chloroform), tetrachloroethene (PCE), tetrahydrofuran, and methylethylketone-were detected at small concentrations in six water samples. Sources of VOCs probably were disinfection, leaking septic systems, or PVC pipe or glue.

Natural and anthropogenic factors contribute to observed water quality. Anthropogenic indicators of young ground-water age-pesticide detection or tritium or nitrate concentrations greater than threshold levelswere identified in about 70 percent (33) of the water samples, and sites were distributed throughout the study area.

Water-quality data were evaluated in the context of agricultural uses. SARs were computed, and one sample had a SAR that might be harmful to soils and crops. SSPs in two samples might be harmful to soils and therefore harmful to crops. Boron concentrations in four samples and selenium concentrations in six samples might be harmful to crops. All sites where water quality might be of concern to agricultural interests are in the southern part of the study area.

\section{REFERENCES}

Agency for Toxic Substances and Disease Registry, 2002, ToxFAQs: Accessed June 5, 2002, at URL http://www.atsdr.cdc.gov/toxfaq.html

Alley, W.M., 1993, Regional ground-water quality: New York, Van Nostrand Reinhold, $634 \mathrm{p}$.

American Public Health Association, 1998, Standard methods for the examination of water and wastewater (20th ed.); Washington, D.C., American Public Health Association, American Water Works Association, and Water Environment Federation, p. 3-37 to 3-43.

American Society for Testing and Materials, 1996, Annual book of ASTM standards, section 11-Water and environmental technology: American Society for Testing and Materials, v. 11.02, D-5072-92, p. 674-676.

Ashworth, J.B., Christian, Prescott, and Waterreus, T.C., 1991, Evaluation of ground-water resources in the southern High Plains of Texas: Texas Water Development Board Report 330, 39 p.

Barbash, J.E., and Resek, E.A., 1996, Pesticides in ground water: Chelsea, Mich., Ann Arbor Press, 588 p.

Bomar, G.W., 1983, Texas weather: Austin, Tex., University of Texas Press, $265 \mathrm{p}$.

Brenton, R.W., and Arnett, T.L., 1993, Methods of analysis by the U.S. Geological Survey National Water Quality Laboratory-Determination of dissolved organic carbon by ultraviolet-light promoted persulfate oxidation and infrared spectrometry: U.S. Geological Survey OpenFile Report 92-480, 12 p.

Bruce, B.W., and Oelsner, G.P., 2001, Contrasting water quality from paired domestic/public supply wells, central High Plains: Journal of the American Water Resources Association, v. 37, no. 5, p. 1,389-1,403.

Childress, C.J.O., Foreman, W.T., Connor, B.F., and Maloney, T.J., 1999, New reporting procedures based on long-term method detection levels and some considerations for interpretations of water-quality data provided by the U.S. Geological Survey National Water Quality Laboratory: U.S. Geological Survey Open-File Report 99-193, $19 \mathrm{p}$.

Connor, B.F., Rose, D.L., Noriega, M.C., Murtagh, L.K., and Abney, S.R., 1998, Methods of analysis by the U.S. Geological Survey National Water Quality Laboratory-Determination of 86 volatile organic compounds in water by gas chromatography/mass spectrometry, including detections less than reporting limits: U.S. Geological Survey Open-File Report 97-829, 78 p.

Crenwelge, Gerald, 1999, Soils of the Llano Estacado regional water planning region: High Plains Underground Water Conservation District No. 1, 28 p.

Dennehy, K.F., 2000, High Plains regional ground water study: U.S. Geological Survey Fact Sheet FS-091-00, $6 \mathrm{p}$.

Dennehy, K.F., Litke, D.W., and McMahon, P.B., 2002, The High Plains aquifer, USA — Groundwater development and sustainability, in Hisack, K.M., Rivett, M.O., and Davison, R.M., eds., Sustainable groundwater development: London, The Geological Society of London, Special Publication 193, p. 99-119.

Extension Toxicology Network, 1996, Pesticide information profiles: Accessed June 5, 2002, at URL http://ace.orst.edu/info/extoxnet/ 
Faires, L.M., 1993, Methods of analysis by the U.S. Geological Survey National Water Quality Laboratory-Determination of metals in water by inductively coupled plasma-mass spectrometry: U.S. Geological Survey Open-File Report 92-634, 28 p.

Fipps, Guy, 1996, Irrigation water quality standards and salinity management strategies: Texas Agricultural Extension Service, Texas A\&M University Systems, B-1667, 19 p.

Fishman, M.J., 1993, Methods of analysis by the U.S. Geological Survey National Water Quality LaboratoryDetermination of inorganic and organic constituents in water and fluvial sediments: U.S. Geological Survey Open-File Report 93-125, 217 p.

Fishman, M.J., and Friedman, L.C., 1989, Methods for the determination of inorganic substances in water and fluvial sediments: U.S. Geological Survey Techniques of Water-Resources Investigations, book 5, chap. A1, $545 \mathrm{p}$.

Furlong, E.T., Anderson, B.D., Werner, S.L., Solvier, P.P., Coffey, L.J., and Burkhardt, M.R., 2001, Methods of analysis by the U.S. Geological Survey National Water Quality Laboratory-Determination of pesticides in water by graphitized carbon-based solid-phase extraction and high performance liquid chromatography/mass spectrometry: U.S. Geological Survey Water-Resources Investigations Report 01-4134, 73 p.

Garbarino, J.R., 1999, Methods of analysis by the U.S. Geological Survey National Water Quality LaboratoryDetermination of dissolved arsenic, boron, lithium, selenium, strontium, thallium, and vanadium using inductively coupled plasma mass-spectrometry: U.S. Geological Survey Open-File Report 99-093, 31 p.

Gilliom, R.J., 2001, Pesticides in the hydrologic systemWhat do we know and what's next: Hydrological Processes, v. 15, p. 3,197-3,201.

Gilliom, R.J., Alley, W.M., and Gurtz, M.E., 1995, Design of the National Water-Quality Assessment ProgramOccurrence and distribution of water-quality conditions: U.S. Geological Survey Circular 1112, 33 p.

Gutentag, E.D., Heimes, F.J., Krothe, N.C., Luckey, R.R., and Weeks, J.B., 1984, Geohydrology of the High Plains aquifer in parts of Colorado, Kansas, Nebraska, New Mexico, Oklahoma, South Dakota, Texas, and Wyoming: U.S. Geological Survey Professional Paper 1400-B, 63 p.

Hem, J.D., 1985, Study and interpretation of the chemical characteristics of natural water (3d ed.): U.S. Geological Survey Water-Supply Paper 2254, 263 p.

Hopkins, Janie, 1993, Water-quality evaluation of the Ogallala aquifer, Texas: Texas Water Development Board Report 342, 41 p.
Hudak, P.F., 2000, Distribution and sources of arsenic in the southern High Plains aquifer, Texas, USA: Journal of Environmental Science and Health, v. A35, no. 6, p. 899-913.

Hughes, C.T., II, 1994, Distribution of radon in the Ogallala aquifer, southern High Plains, Texas: Lubbock, Tex., Texas Tech University Master's thesis, 83 p.

Knowles, T.R., Nordstrom, P.L., and Klemt, W.B., 1982, Evaluating the ground-water resources of the High Plains of Texas, final report: Texas Department of Water Resources LP-173, v. 1, 179 p.

Koterba, M.T., 1998, Ground-water data-collection protocols and procedures for the National Water-Quality Assessment Program-Collection, documentation, and compilation of required site, well, subsurface, and landscape data for wells: U.S. Geological Survey WaterResources Investigations Report 98-4107, 91 p.

Koterba, M.T., Wilde, F.D., and Lapham, W.W., 1995, Ground-water data-collection protocols and procedures for the National Water-Quality Assessment ProgramCollection and documentation of water-quality samples and related data: U.S. Geological Survey Open-File Report 95-399, 113 p.

Lapham, W.W., Wilde, F.D., and Koterba, M.T., 1995, Ground-water data-collection protocols and procedures for the National Water-Quality Assessment ProgramSelection, installation, and documentation of wells, and collection of related data: U.S. Geological Survey OpenFile Report 95-398, 69 p.

Litke, D.W., 2001, Historical water-quality data for the High Plains regional ground-water study area in Colorado, Kansas, Nebraska, New Mexico, Oklahoma, South Dakota, Texas, and Wyoming, 1930-98: U.S. Geological Survey Water-Resources Investigations Report 00-4254, 65 p.

Mahler, B.J., Gary, M.O., Canova, M.G., Strom, E.W., Fahlquist, Lynne, and Dorsey, M.E., 2002, Volatile organic compound and pesticide data for public watersupply reservoirs and wells, Texas, 1999-2001: U.S. Geological Survey Open-File Report 02-093, 105 p.

McClain, Betty, 1993, Methods of analysis by the U.S. Geological Survey National Water Quality LaboratoryDetermination of chromium in water by graphite furnace atomic absorption spectrophotometry, U.S. Geological Survey Open-File Report 93-499, 16 p.

McMahon, P.B., 2001, Vertical gradients in water chemistry in the central High Plains aquifer, southwestern Kansas and Oklahoma panhandle, 1999: U.S. Geological Survey Water-Resources Investigations Report 01-4028, $47 \mathrm{p}$.

Meister, R.T, 1997, Farm chemicals handbook '97: Willoughby, Ohio, Meister Publishing Co. [variously paged]. 
Moran, M.J., Lapham, W.W., Rowe, B.L., and Zogorski, J.S., 2002, Occurrence and status of volatile organic compounds in ground water from rural, untreated, selfsupplied domestic wells in the United States, 1986-99: U.S. Geological Survey Water-Resources Investigations Report 02-4085, 51 p.

Mullican, W.F., III, Johns, N.D., and Fryar, A.E., 1997, Playas and recharge of the Ogallala aquifer on the southern High Plains of Texas-An examination using numerical techniques: University of Texas, Bureau of Economic Geology Report of Investigations 242, 72 p.

Nativ, Ronit, 1988, Hydrogeology and hydrochemistry of the Ogallala aquifer, southern High Plains, Texas Panhandle and eastern New Mexico: University of Texas, Bureau of Economic Geology Report of Investigations 177, 64 p.

Patton, C.J., and Truitt, E.P., 2000, Methods of analysis by the U.S. Geological Survey National Water Quality Laboratory-Determination of ammonium plus organic nitrogen by a Kjeldahl digestion method and an automated photometric finish that includes digest cleanup by gas diffusion: U.S. Geological Survey Open-File Report 00-170, $31 \mathrm{p}$.

Quiring, S.M., and Pennington, H.D., 1989, Drinking water standards: Texas Agricultural Extension Service, Texas A\&M University Systems, B-1643, 8 p.

Schriver, Steven, and Hopkins, Janie, 1998, Updated waterquality evaluation of the Ogallala aquifer including selected metallic and non-metallic inorganic constituents: Texas Water Development Board Hydrologic Atlas 10, 10 p.

Scott, J.C., 1990, Computerized stratified random siteselection approaches for design of a ground-waterquality sampling network: U.S. Geological Survey Water-Resources Investigations Report 90-4101, 109 p.

Seni, S.J., 1980, Sand-body geometry and depositional systems, Ogallala Formation, Texas: University of Texas, Bureau of Economic Geology Report of Investigations $105,36 \mathrm{p}$.

Texas State Historical Association, 2002, The handbook of Texas online: Accessed June 23, 2002, at URL http://www.tsha.utexas.edu/handbook/online/ articles/view/LL/ryl2.html

Texas State Library and Archives Commission, 2002, About Texas: Accessed June 5, 2002, at URL http://www.tsl.state.tx.us/ref/abouttx/\#cities

Texas Water Development Board, 2002a, Llano Estacado regional water plan: Accessed June 5, 2002, at URL http://www.twdb.state.tx.us/rwp/o/

2002b, Panhandle regional water plan: Accessed June 5, 2002, at URL http://www.twdb.state.tx.us/rwp/a/

Thatcher, L.L., Janzer, V.J., and Edwards, K.W., 1977, Methods for determination of radioactive substances in water and fluvial sediments: U.S. Geological Survey
Techniques of Water-Resources Investigations, book 5, chap. A5, $95 \mathrm{p}$.

Timme, P.J., 1995, National Water Quality Laboratory 1995 services catalog: U.S. Geological Survey Open-File Report 95-352, 120 p.

University of New Mexico, Bureau of Business and Economic Research, 2002, City population estimates: Accessed June 5, 2002, at URL http://www.unm.edu/ bber/demo/nmcirnk3.htm

U.S. Census Bureau, 2002, State and county quick facts: Accessed June 6, 2002, at URL http://quickfacts.census.gov/qfd/states/35000.html

U.S. Department of Agriculture, 2002a, National agricultural statistics service data base-2002 crop production summary with comparisons: Accessed January 17, 2003, at URL

http://www.nass.usda.gov/tx/tcrpsum.txt

2002 b, National agricultural statistics service data base: Accessed June 5, 2002, at URL http://www.nass.usda.gov:81/ipedb/

U.S. Environmental Protection Agency, 1983, Methods for chemical analysis of water and wastes, U.S. Environmental Protection Agency Report EPA/600/4-79/020.

1989, Drinking water health advisory-Pesticides: Chelsea, Mich., Lewis Publishers, 819 p.

1999, Proposed radon in drinking water rule: U.S. Environmental Protection Agency Report 815-F-99-006, 4 p.

2000, Drinking water regulations and health advisories: U.S. Environmental Protection Agency Report EPA 822-B-00-001, 12 p.

2002, Current drinking-water standards: Office of Ground Water and Drinking Water, accessed June 26, 2002, at URL http://www.epa.gov/safewater/mcl.html

U.S. Geological Survey, 1997-present, National field manual for the collection of water-quality data: U.S. Geological Survey Techniques of Water-Resources Investigations, book 9, chaps. A1-A9, accessed July 1, 2001, at URL http://water.usgs.gov/owq/FieldManual/

1999, The quality of our Nation's waters-Nutrients and pesticides: U.S. Geological Survey Circular 1225, $82 \mathrm{p}$.

Weeks, J.B., Gutentag, E.D., Heimes, F.J., and Luckey, R.R., 1988, Summary of the High Plains Regional AquiferSystem Analysis in parts of Colorado, Kansas, Nebraska, New Mexico, Oklahoma, South Dakota, Texas, and Wyoming: U.S. Geological Survey Professional Paper 1400-A, 30 p.

Welch, A.J., Westjohn, D.B., Helsel, D.R., and Wanty, R.B., 2000, Arsenic in ground water of the United StatesOccurrence and geochemistry: Ground Water, v. 38, no. 4, p. 589-604. 
Wood, W.W., 2000, Ground-water recharge in the southern High Plains of Texas and New Mexico: U.S. Geological Survey Fact Sheet FS-127-99, 4 p.

Zaugg, S.D., Sandstrom, M.W., Smith, S.G., and Fehlberg, K.M., 1995, Methods of analysis by the U.S. Geological
Survey National Water Quality Laboratory-Determination of pesticides in water by $\mathrm{C}-18$ solid-phase extraction of capillary-column gas chromatography/ mass spectrometry with selected-ion monitoring: U.S. Geological Survey Open-File Report 95-181, 60 p. 
Appendixes 
Appendix 1. Site location and well information for primarily domestic wells screened in the southern High Plains aquifer that were sampled for water quality, Texas and New Mexico, 2001

[ft, feet; PVC, polyvinyl chloride]

\begin{tabular}{|c|c|c|c|c|c|c|c|c|c|c|}
\hline $\begin{array}{c}\text { State } \\
\text { well no. }\end{array}$ & State & County & Latitude & Longitude & $\begin{array}{l}\text { Date } \\
\text { drilled }\end{array}$ & $\begin{array}{c}\text { Casing } \\
\text { mate- } \\
\text { rial }\end{array}$ & $\begin{array}{c}\text { Total } \\
\text { depth } \\
\text { of well } \\
\text { (ft) }\end{array}$ & $\begin{array}{l}\text { Depth to } \\
\text { top of } \\
\text { screened } \\
\text { interval } \\
\text { (ft) }\end{array}$ & $\begin{array}{l}\text { Length } \\
\text { of } \\
\text { screened } \\
\text { interval } \\
\text { (ft) }\end{array}$ & $\begin{array}{l}\text { Depth } \\
\text { to water } \\
\text { below } \\
\text { land } \\
\text { surface } \\
\text { (ft) }\end{array}$ \\
\hline NM03N.36E.28.411 & N. Mex. & Curry & $34^{\circ} 27^{\prime} 18^{\prime \prime}$ & $103^{\circ} 10^{\prime} 08^{\prime \prime}$ & $05 / 11 / 1992$ & PVC & 430 & 410 & 20 & 360 \\
\hline NM05N.34E.36.244 & N. Mex. & Curry & $34^{\circ} 36^{\prime} 42^{\prime \prime}$ & $103^{\circ} 17^{\prime} 10^{\prime \prime}$ & $10 / 02 / 1991$ & Steel & 500 & 480 & 20 & 445 \\
\hline NM13S.38E.14.3333A & N. Mex. & Lea & $33^{\circ} 11^{\prime} 06^{\prime \prime}$ & $103^{\circ} 04^{\prime} 32^{\prime \prime}$ & $05 / 23 / 2001$ & PVC & 170 & 130 & 40 & 117 \\
\hline NM15S.38E.14.211 & N. Mex. & Lea & $33^{\circ} 01^{\prime} 26^{\prime \prime}$ & $103^{\circ} 04^{\prime} 01^{\prime \prime}$ & $10 / 15 / 1982$ & Steel & 142 & 130 & 12 & 90.4 \\
\hline NM01N.36E.21.233 & N. Mex. & Roosevelt & $34^{\circ} 17^{\prime} 46^{\prime \prime}$ & $103^{\circ} 10^{\prime} 05^{\prime \prime}$ & $04 / 12 / 1978$ & PVC & 354 & 336 & 18 & 288 \\
\hline NM02S.36E.17.231 & N. Mex. & Roosevelt & $34^{\circ} 08^{\prime} 13^{\prime \prime}$ & $103^{\circ} 11^{\prime} 14^{\prime \prime}$ & 08/25/1997 & PVC & 140 & 120 & 20 & 98.0 \\
\hline AB-27-29-905 & Tex. & Andrews & $32^{\circ} 30^{\prime} 55^{\prime \prime}$ & $102^{\circ} 23^{\prime} 28^{\prime \prime}$ & 08/17/1998 & PVC & 190 & 170 & 20 & 129 \\
\hline AR-25-08-603 & Tex. & Bailey & $33^{\circ} 57^{\prime} 27^{\prime \prime}$ & $103^{\circ} 00^{\prime} 01^{\prime \prime}$ & 06/27/1978 & PVC & 197 & 137 & 60 & 124 \\
\hline BL-11-38-925 & Tex. & Briscoe & $34^{\circ} 24^{\prime} 19^{\prime \prime}$ & $101^{\circ} 15^{\prime} 43^{\prime \prime}$ & 10/16/1992 & Steel & 200 & 14 & 186 & 139 \\
\hline DD-10-30-803 & Tex. & Castro & $34^{\circ} 30^{\prime} 39^{\prime \prime}$ & $102^{\circ} 18^{\prime} 07^{\prime \prime}$ & 06/30/1993 & PVC & 398 & 358 & 40 & 323 \\
\hline DP-24-19-405 & Tex. & Cochran & $33^{\circ} 42^{\prime} 21^{\prime \prime}$ & $102^{\circ} 44^{\prime} 30^{\prime \prime}$ & $04 / 25 / 2000$ & PVC & 218 & 158 & 60 & 168 \\
\hline DP-24-20-705 & Tex. & Cochran & $33^{\circ} 39^{\prime} 29^{\prime \prime}$ & $102^{\circ} 37^{\prime} 00^{\prime \prime}$ & $03 / 25 / 2000$ & PVC & 195 & 155 & 40 & 164 \\
\hline HK-23-14-404 & Tex. & Crosby & $33^{\circ} 47^{\prime} 59^{\prime \prime}$ & $101^{\circ} 21^{\prime} 55^{\prime \prime}$ & 02/27/1998 & PVC & 351 & 311 & 40 & 269 \\
\hline HK-23-29-104 & Tex. & Crosby & $33^{\circ} 36^{\prime} 03^{\prime \prime}$ & $101^{\circ} 28^{\prime} 08^{\prime \prime}$ & 09/23/1993 & PVC & 300 & 200 & 100 & 120 \\
\hline HS-28-09-808 & Tex. & Dawson & $32^{\circ} 45^{\prime} 51^{\prime \prime}$ & $101^{\circ} 57^{\prime} 07^{\prime \prime}$ & 04/23/1975 & PVC & 190 & 140 & 50 & 81.6 \\
\hline HS-28-27-411 & Tex. & Dawson & $32^{\circ} 33^{\prime} 39^{\prime \prime}$ & $101^{\circ} 44^{\prime} 43^{\prime \prime}$ & $09 / 24 / 2000$ & PVC & 175 & 95 & 80 & 82.0 \\
\hline HT-10-13-345 & Tex. & Deaf Smith & $34^{\circ} 51^{\prime} 56^{\prime \prime}$ & $102^{\circ} 23^{\prime} 28^{\prime \prime}$ & 09/16/1981 & Steel & 325 & 260 & 65 & 200 \\
\hline HT-10-13-640 & Tex. & Deaf Smith & $34^{\circ} 48^{\prime} 04^{\prime \prime}$ & $102^{\circ} 23^{\prime} 50^{\prime \prime}$ & 08/04/1989 & PVC & 350 & 280 & 70 & 207 \\
\hline JW-23-08-101 & Tex. & Floyd & $33^{\circ} 57^{\prime} 50^{\prime \prime}$ & $101^{\circ} 06 ' 52^{\prime \prime}$ & 05/23/1978 & PVC & 330 & 290 & 40 & 288 \\
\hline KD-26-24-203 & Tex. & Gaines & $32^{\circ} 43^{\prime} 57^{\prime \prime}$ & $103^{\circ} 03^{\prime} 29^{\prime \prime}$ & $12 / 23 / 1996$ & PVC & 202 & 182 & 20 & 106 \\
\hline KD-27-01-807 & Tex. & Gaines & $32^{\circ} 55^{\prime} 00^{\prime \prime}$ & $102^{\circ} 57^{\prime} 02^{\prime \prime}$ & 10/29/1997 & PVC & 218 & 198 & 20 & 152 \\
\hline KD-27-19-518 & Tex. & Gaines & $32^{\circ} 41^{\prime} 53^{\prime \prime}$ & $102^{\circ} 40^{\prime} 55^{\prime \prime}$ & 03/05/1998 & PVC & 193 & 153 & 40 & 126 \\
\hline KD-27-30-103 & Tex. & Gaines & $32^{\circ} 36^{\prime} 52^{\prime \prime}$ & $102^{\circ} 20^{\prime} 21^{\prime \prime}$ & 04/20/1989 & PVC & 100 & 80 & 20 & 39.6 \\
\hline KY-11-43-805 & Tex. & Hale & $34^{\circ} 16^{\prime} 45^{\prime \prime}$ & $101^{\circ} 41^{\prime} 31^{\prime \prime}$ & 09/26/1991 & PVC & 278 & 245 & 33 & 233 \\
\hline KY-11-49-207 & Tex. & Hale & $34^{\circ} 12^{\prime} 49^{\prime \prime}$ & $101^{\circ} 57^{\prime} 04^{\prime \prime}$ & 05/17/1992 & PVC & 292 & 252 & 40 & 228 \\
\hline KY-23-03-904 & Tex. & Hale & $33^{\circ} 52^{\prime} 31^{\prime \prime}$ & $101^{\circ} 38^{\prime} 12^{\prime \prime}$ & 02/07/1989 & Steel & 265 & 205 & 60 & 245 \\
\hline KY-23-10-304 & Tex. & Hale & $33^{\circ} 50^{\prime} 35^{\prime \prime}$ & $101^{\circ} 46 ' 57^{\prime \prime}$ & 04/06/1996 & PVC & 336 & 196 & 100 & 185 \\
\hline PB-28-37-307 & Tex. & Howard & $32^{\circ} 29^{\prime} 04^{\prime \prime}$ & $101^{\circ} 22^{\prime} 35^{\prime \prime}$ & 04/08/1989 & PVC & 100 & 60 & 40 & 73.6 \\
\hline RU-10-52-107 & Tex. & Lamb & $34^{\circ} 13^{\prime} 18^{\prime \prime}$ & $102^{\circ} 35^{\prime} 52^{\prime \prime}$ & 07/08/1999 & PVC & 190 & 130 & 60 & 129 \\
\hline RU-10-55-407 & Tex. & Lamb & $34^{\circ} 11^{\prime} 37^{\prime \prime}$ & $102^{\circ} 14^{\prime} 47^{\prime \prime}$ & 07/31/1996 & PVC & 328 & 268 & 40 & 228 \\
\hline SP-23-17-712 & Tex. & Lubbock & $33^{\circ} 38^{\prime} 11^{\prime \prime}$ & 1015'34" & 08/05/1999 & PVC & 175 & 95 & 80 & 92.4 \\
\hline SP-23-25-904 & Tex. & Lubbock & $33^{\circ} 30^{\prime} 03^{\prime \prime}$ & $101^{\circ} 53^{\prime} 10^{\prime \prime}$ & 08/18/1978 & PVC & 108 & 98 & 10 & 33.6 \\
\hline SR-23-41-502 & Tex. & Lynn & $33^{\circ} 19^{\prime} 01^{\prime \prime}$ & $101^{\circ} 55^{\prime} 38^{\prime \prime}$ & 04/30/1997 & PVC & 124 & 84 & 40 & 71.6 \\
\hline SY-27-48-611 & Tex. & Martin & $32^{\circ} 18^{\prime} 22^{\prime \prime}$ & $102^{\circ} 02^{\prime} 18^{\prime \prime}$ & $10 / 20 / 1980$ & PVC & 175 & 115 & 60 & 115 \\
\hline SY-28-42-707 & Tex. & Martin & $32^{\circ} 15^{\prime} 36^{\prime \prime}$ & $101^{\circ} 50^{\prime} 43^{\prime \prime}$ & 02/16/1999 & PVC & 132 & 112 & 20 & 63.8 \\
\hline SY-28-58-204 & Tex. & Martin & $32^{\circ} 07^{\prime} 29^{\prime \prime}$ & $101^{\circ} 48^{\prime} 46^{\prime \prime}$ & 04/27/1990 & PVC & 165 & 135 & 30 & 106 \\
\hline $\mathrm{UH}-07-53-228$ & Tex. & Oldham & $35^{\circ} 13^{\prime} 26^{\prime \prime}$ & $102^{\circ} 25^{\prime} 11^{\prime \prime}$ & 02/11/1987 & PVC & 325 & 245 & 70 & 219 \\
\hline UR-10-19-506 & Tex. & Parmer & $34^{\circ} 40^{\prime} 02^{\prime \prime}$ & $102^{\circ} 42^{\prime} 25^{\prime \prime}$ & 10/02/1998 & Steel & 497 & 437 & 60 & 268 \\
\hline UR-10-42-204 & Tex. & Parmer & $34^{\circ} 21^{\prime} 03^{\prime \prime}$ & $102^{\circ} 48^{\prime} 07^{\prime \prime}$ & 02/26/1998 & PVC & 368 & 308 & 60 & 254 \\
\hline UY-06-57-824 & Tex. & Randall & $35^{\circ} 00^{\prime} 53^{\prime \prime}$ & $101^{\circ} 55^{\prime} 15^{\prime \prime}$ & 07/23/1988 & Steel & 315 & 267 & 36 & 106 \\
\hline UY-10-07-631 & Tex. & Randall & $34^{\circ} 57^{\prime} 29^{\prime \prime}$ & $102^{\circ} 08^{\prime} 50^{\prime \prime}$ & 06/25/1987 & Steel & 206 & 119 & 87 & 111 \\
\hline XT-11-44-605 & Tex. & Swisher & $34^{\circ} 19^{\prime} 06^{\prime \prime}$ & $101^{\circ} 31^{\prime} 39^{\prime \prime}$ & 08/11/1998 & PVC & 270 & 250 & 20 & 238 \\
\hline $\mathrm{XY}-24-45-502$ & Tex. & Terry & $33^{\circ} 19^{\prime} 09^{\prime \prime}$ & $102^{\circ} 26^{\prime} 48^{\prime \prime}$ & 02/12/1994 & PVC & 208 & 168 & 40 & 158 \\
\hline XY-24-47-207 & Tex. & Terry & $33^{\circ} 21^{\prime} 00^{\prime \prime}$ & $102^{\circ} 11^{\prime} 51^{\prime \prime}$ & 10/04/1999 & PVC & 144 & 104 & 40 & 73.3 \\
\hline $\mathrm{XY}-24-62-801$ & Tex. & Terry & $33^{\circ} 01^{\prime} 16^{\prime \prime}$ & $102^{\circ} 18^{\prime} 13^{\prime \prime}$ & 04/16/1996 & PVC & 175 & 115 & 60 & 145 \\
\hline ZT-24-43-202 & Tex. & Yoakum & $33^{\circ} 21^{\prime} 04^{\prime \prime}$ & $102^{\circ} 41^{\prime} 48^{\prime \prime}$ & 07/16/1997 & PVC & 150 & 110 & 40 & 146 \\
\hline ZT-24-50-602 & Tex. & Yoakum & $33^{\circ} 10^{\prime} 54^{\prime \prime}$ & $102^{\circ} 47^{\prime} 28^{\prime \prime}$ & 02/15/1994 & PVC & 100 & 80 & 20 & 50.3 \\
\hline ZT-25-40-804 & Tex. & Yoakum & $33^{\circ} 23^{\prime} 01^{\prime \prime}$ & $103^{\circ} 02^{\prime} 44^{\prime \prime}$ & 09/29/1990 & PVC & 197 & 137 & 60 & 60.0 \\
\hline
\end{tabular}


Appendix 2. Field measurements and major ion concentrations in water sampled from primarily domestic wells screened in the southern High Plains aquifer, Texas and New Mexico, 2001

[ft, feet; $\mu \mathrm{S} / \mathrm{cm}$, microsiemens per centimeter at 25 degrees Celsius; ${ }^{\circ} \mathrm{C}$, degrees Celsius; NTU, nephelometric turbidity unit; $\mathrm{mg} / \mathrm{L}$, milligrams per liter; --, not measured; <, not detected at this reporting level]

\begin{tabular}{|c|c|c|c|c|c|c|c|c|}
\hline $\begin{array}{c}\text { State } \\
\text { well no. }\end{array}$ & $\begin{array}{l}\text { Sample } \\
\text { date }\end{array}$ & $\begin{array}{c}\text { Specific } \\
\text { conductance, } \\
\text { field } \\
(\mu \mathrm{S} / \mathrm{cm})\end{array}$ & $\begin{array}{l}\mathrm{pH} \text {, field } \\
\text { (standard } \\
\text { units) }\end{array}$ & $\begin{array}{l}\text { Water } \\
\text { temperature, } \\
\text { field } \\
\left({ }^{\circ} \mathrm{C}\right)\end{array}$ & $\begin{array}{l}\text { Turbidity, } \\
\text { field } \\
\text { (NTU) }\end{array}$ & $\begin{array}{l}\text { Dissolved } \\
\text { oxygen, } \\
\text { field } \\
\text { (mg/L) }\end{array}$ & $\begin{array}{c}\text { Alkalinity, } \\
\text { field } \\
(\mathrm{mg} / \mathrm{L} \text { as } \\
\left.\mathrm{CaCO}_{3}\right)\end{array}$ & $\begin{array}{l}\text { Dissolved } \\
\text { solids, } \\
\text { residue } \\
\text { (mg/L) }\end{array}$ \\
\hline NM03N.36E.28.411 & $08 / 24 / 2001$ & 477 & 7.6 & 20.8 & 0.11 & 7.5 & 170 & 297 \\
\hline NM05N.34E.36.244 & $09 / 23 / 2001$ & 455 & 7.6 & 19.9 & .13 & 6.5 & 217 & 270 \\
\hline NM13S.38E.14.3333A & $09 / 25 / 2001$ & 807 & 7.4 & 18.4 & .16 & 5.8 & 174 & 536 \\
\hline NM15S.38E.14.211 & $08 / 11 / 2001$ & 1,240 & 6.7 & 19.3 & .22 & 4.2 & 225 & 774 \\
\hline NM01N.36E.21.233 & $09 / 23 / 2001$ & 497 & 7.7 & 18.7 & .56 & 8.2 & 187 & 299 \\
\hline NM02S.36E.17.231 & $08 / 24 / 2001$ & 729 & 7.3 & 21.7 & .27 & 5.6 & 158 & 500 \\
\hline AB-27-29-905 & $08 / 13 / 2001$ & 859 & 7.6 & 20.2 & .04 & 6.2 & 234 & 520 \\
\hline AR-25-08-603 & $09 / 22 / 2001$ & 548 & 7.6 & 18.4 & .51 & 8.7 & 180 & 327 \\
\hline BL-11-38-925 & $08 / 19 / 2001$ & 843 & 7.4 & 18.2 & 2.11 & 3.2 & 298 & 552 \\
\hline DD-10-30-803 & $09 / 21 / 2001$ & 844 & 7.3 & 17.4 & .43 & 7.8 & 170 & 531 \\
\hline DP-24-19-405 & $09 / 24 / 2001$ & 1,220 & 7.4 & 18.8 & .23 & 4.3 & 213 & 806 \\
\hline DP-24-20-705 & 09/24/2001 & 1,450 & 7.4 & 18.2 & .24 & .5 & 237 & 936 \\
\hline HK-23-14-404 & $08 / 18 / 2001$ & 785 & 7.4 & 20.1 & .52 & 5.2 & 306 & 478 \\
\hline HK-23-29-104 & $09 / 18 / 2001$ & 1,380 & 7.2 & 18.3 & 158 & 6.4 & 221 & 796 \\
\hline HS-28-09-808 & 08/16/2001 & 1,920 & 7.3 & 19.9 & 1.76 & 7.7 & 228 & 1,220 \\
\hline HS-28-27-411 & $08 / 15 / 2001$ & 660 & 6.9 & 22.1 & 7.51 & 6.3 & 316 & 400 \\
\hline HT-10-13-345 & $08 / 21 / 2001$ & 625 & 7.4 & 18.0 & 4.66 & 6.0 & 242 & 373 \\
\hline HT-10-13-640 & $09 / 21 / 2001$ & 778 & 7.3 & 17.4 & .38 & 3.7 & 235 & 501 \\
\hline JW-23-08-101 & 09/18/2001 & 646 & 7.3 & 18.9 & .62 & 4.0 & 284 & 376 \\
\hline KD-26-24-203 & 08/13/2001 & 559 & 7.4 & 20.7 & .14 & 6.0 & 162 & 367 \\
\hline KD-27-01-807 & $08 / 12 / 2001$ & 1,460 & 7.2 & 21.2 & .12 & 3.2 & 159 & 940 \\
\hline KD-27-19-518 & 08/13/2001 & 1,570 & 7.2 & 19.8 & .88 & 4.7 & 193 & 954 \\
\hline KD-27-30-103 & 08/14/2001 & 4,090 & 7.1 & 19.3 & .28 & 4.4 & 271 & 2,540 \\
\hline $\mathrm{KY}-11-43-805$ & $08 / 25 / 2001$ & 885 & 7.1 & 23.7 & .38 & .4 & 278 & 558 \\
\hline KY-11-49-207 & 09/20/2001 & 553 & 7.3 & 18.2 & .18 & 1.2 & 268 & 342 \\
\hline KY-23-03-904 & 09/19/2001 & 960 & 7.3 & 18.6 & 1.76 & 7.3 & 227 & 555 \\
\hline KY-23-10-304 & 09/19/2001 & 740 & 7.4 & 21.6 & .94 & 3.3 & 269 & 448 \\
\hline PB-28-37-307 & $09 / 26 / 2001$ & 1,740 & 7.2 & 20.8 & .73 & 9.3 & 150 & 1,150 \\
\hline RU-10-52-107 & $09 / 22 / 2001$ & 1,380 & 7.6 & 18.1 & 1.00 & 4.2 & 236 & 892 \\
\hline RU-10-55-407 & $08 / 26 / 2001$ & 767 & 7.2 & 19.4 & .24 & .7 & 220 & 453 \\
\hline SP-23-17-712 & 08/10/2001 & 1,810 & 7.2 & 19.2 & .82 & 4.2 & 244 & 1,170 \\
\hline SP-23-25-904 & $08 / 17 / 2001$ & 893 & 7.6 & 19.2 & .21 & 5.2 & 278 & 567 \\
\hline SR-23-41-502 & $08 / 17 / 2001$ & 2,200 & 6.9 & 19.2 & .17 & 4.6 & 372 & 1,570 \\
\hline SY-27-48-611 & $08 / 14 / 2001$ & 3,480 & 7.0 & 21.4 & .51 & 5.7 & 191 & 2,040 \\
\hline SY-28-42-707 & $08 / 15 / 2001$ & 1,120 & 7.2 & 20.6 & 6.68 & 8.0 & 234 & 690 \\
\hline SY-28-58-204 & $09 / 26 / 2001$ & 965 & 7.4 & 20.6 & .23 & 8.7 & 240 & 614 \\
\hline $\mathrm{UH}-07-53-228$ & $08 / 21 / 2001$ & 576 & 7.4 & 17.8 & .11 & 6.6 & 214 & 361 \\
\hline UR-10-19-506 & $08 / 22 / 2001$ & 569 & 7.7 & 20.0 & 16.7 & 1.9 & 242 & 349 \\
\hline UR-10-42-204 & $08 / 22 / 2001$ & 508 & 7.4 & 19.1 & .12 & 7.4 & 192 & 314 \\
\hline UY-06-57-824 & 08/20/2001 & 957 & 7.1 & 18.0 & .08 & 2.4 & 306 & 660 \\
\hline UY-10-07-631 & $08 / 20 / 2001$ & 673 & 7.4 & 17.5 & .08 & 1.1 & 294 & 453 \\
\hline XT-11-44-605 & $08 / 25 / 2001$ & 636 & 7.2 & 18.3 & .20 & .9 & 280 & 401 \\
\hline$X Y-24-45-502$ & 08/07/2001 & 1,730 & 7.1 & 18.8 & .14 & 6.9 & 241 & 1,160 \\
\hline$X Y-24-47-207$ & 08/16/2001 & 2,400 & 7.1 & 18.9 & .23 & 1.5 & 542 & 1,550 \\
\hline$X Y-24-62-801$ & 08/08/2001 & 1,390 & 7.3 & 19.8 & .13 & 6.0 & 232 & 870 \\
\hline ZT-24-43-202 & $08 / 12 / 2001$ & 847 & 7.3 & 19.1 & .09 & 5.1 & 256 & 493 \\
\hline ZT-24-50-602 & $08 / 11 / 2001$ & 1,760 & 7.4 & 20.3 & .18 & 6.6 & 214 & 776 \\
\hline ZT-25-40-804 & $09 / 25 / 2001$ & 745 & 7.6 & 18.2 & 5.00 & 5.9 & 194 & 496 \\
\hline
\end{tabular}


Appendix 2. Field measurements and major ion concentrations in water sampled from primarily domestic wells screened in the southern High Plains aquifer, Texas and New Mexico, 2001—Continued

\begin{tabular}{|c|c|c|c|c|c|c|c|c|c|c|}
\hline $\begin{array}{c}\text { State } \\
\text { well no. }\end{array}$ & $\begin{array}{c}\text { Calcium } \\
\text { (mg/L) }\end{array}$ & $\begin{array}{l}\text { Magnesium } \\
\quad(\mathrm{mg} / \mathrm{L})\end{array}$ & $\begin{array}{l}\text { Sodium } \\
\text { (mg/L) }\end{array}$ & $\begin{array}{l}\text { Potassium } \\
\text { (mg/L) }\end{array}$ & $\begin{array}{l}\text { Sulfate } \\
\text { (mg/L) }\end{array}$ & $\begin{array}{l}\text { Sulfide, } \\
\text { field } \\
(\mathrm{mg} / \mathrm{L})\end{array}$ & $\begin{array}{c}\text { Chloride } \\
\text { (mg/L) }\end{array}$ & $\begin{array}{c}\text { Fluoride } \\
\text { (mg/L) }\end{array}$ & $\begin{array}{c}\text { Bromide } \\
\text { (mg/L) }\end{array}$ & $\begin{array}{l}\text { Silica } \\
\text { (mg/L) }\end{array}$ \\
\hline NM03N.36E.28.411 & 29.2 & 21.7 & 35.9 & 6.26 & 31.0 & - & 21.4 & 2.4 & 0.11 & 29.4 \\
\hline NM05N.34E.36.244 & 29.6 & 18.6 & 36.7 & 5.02 & 19.1 & -- & 7.6 & 1.5 & .07 & 29.0 \\
\hline NM13S.38E.14.3333A & 79.1 & 22.2 & 54.7 & 2.41 & 134 & -- & 75.4 & 1.8 & .72 & 53.4 \\
\hline NM15S.38E.14.211 & 130 & 39.9 & 63.5 & 3.45 & 198 & -- & 120 & .9 & 1.02 & 61.4 \\
\hline NM01N.36E.21.233 & 29.7 & 25.9 & 31.3 & 6.38 & 46 & -- & 11.7 & 2.6 & .08 & 43.9 \\
\hline NM02S.36E.17.231 & 68.1 & 26.1 & 33.6 & 5.88 & 140 & -- & 32.5 & .4 & .35 & 36.3 \\
\hline AB-27-29-905 & 30.2 & 43.9 & 78.3 & 7.38 & 93.9 & -- & 69.1 & 7.7 & .6 & 55.1 \\
\hline AR-25-08-603 & 34.9 & 21.0 & 44.3 & 6.46 & 50.6 & -- & 27.1 & 2.3 & .22 & 27.2 \\
\hline BL-11-38-925 & 33.4 & 46.0 & 72.1 & 9.86 & 101 & -- & 20.4 & 4.8 & .16 & 67.0 \\
\hline DD-10-30-803 & 65.1 & 53.9 & 17.6 & 8.22 & 101 & -- & 94.0 & 1.7 & .47 & 28.0 \\
\hline DP-24-19-405 & 75.9 & 66.1 & 69.5 & 7.75 & 229 & -- & 136 & 3.3 & .97 & 48.3 \\
\hline DP-24-20-705 & 92.6 & 88.3 & 64.7 & 10.8 & 292 & -- & 167 & 2.8 & 1.09 & 44.4 \\
\hline HK-23-14-404 & 32.1 & 31.7 & 85.4 & 9.78 & 55.8 & -- & 25.5 & 4.1 & .11 & 41.3 \\
\hline HK-23-29-104 & 79.4 & 94.9 & 29.2 & 14.2 & 81.2 & -- & 230 & 3.2 & 1.26 & 56.5 \\
\hline HS-28-09-808 & 76.6 & 130 & 107 & 21.9 & 366 & -- & 297 & 8.2 & 1.84 & 52.3 \\
\hline HS-28-27-411 & 97.2 & 13.3 & 16.2 & 7.88 & 18.2 & -- & 15.3 & 1.0 & .19 & 37.4 \\
\hline HT-10-13-345 & 38.7 & 29.7 & 45.5 & 6.00 & 33.3 & -- & 23.5 & 1.8 & .15 & 28.1 \\
\hline HT-10-13-640 & 54.6 & 42.6 & 41.0 & 6.67 & 72.9 & -- & 65.0 & 1.9 & .35 & 44.2 \\
\hline JW-23-08-101 & 34.8 & 31.6 & 54.7 & 8.14 & 33.4 & -- & 16.3 & 3.3 & .12 & 45.1 \\
\hline KD-26-24-203 & 55.2 & 18.1 & 30.2 & 2.39 & 57.0 & -- & 32.0 & 1.5 & .33 & 61.7 \\
\hline KD-27-01-807 & 138 & 48.9 & 80.2 & 4.01 & 264 & -- & 204 & 1.4 & 1.71 & 57.8 \\
\hline KD-27-19-518 & 101 & 86.8 & 74.4 & 5.45 & 234 & -- & 229 & 4.3 & 1.67 & 59.9 \\
\hline KD-27-30-103 & 240 & 145 & 408 & 12.8 & 603 & -- & 917 & 5.0 & 5.84 & 75.5 \\
\hline KY-11-43-805 & 71.3 & 44.7 & 40.5 & 8.89 & 69.7 & 0.008 & 67.0 & 1.7 & .39 & 55.6 \\
\hline KY-11-49-207 & 35.8 & 21.3 & 51.5 & 6.48 & 16.9 & -- & 10.6 & 2.3 & .09 & 41.8 \\
\hline KY-23-03-904 & 47.2 & 44.4 & 68.3 & 10.9 & 45.5 & -- & 123 & 2.6 & .85 & 44.8 \\
\hline KY-23-10-304 & 40.3 & 28.7 & 78.1 & 8.54 & 36.8 & -- & 60.2 & 2.0 & .26 & 40.2 \\
\hline PB-28-37-307 & 146 & 46.2 & 105 & 7.93 & 64.3 & -- & 412 & 1.6 & 1.89 & 45.7 \\
\hline RU-10-52-107 & 36.5 & 57.4 & 160 & 21.0 & 267 & -- & 141 & 1.7 & 1.07 & 35.3 \\
\hline RU-10-55-407 & 58.8 & 38.5 & 32.4 & 7.60 & 36.3 & .008 & 71.1 & 2.1 & .34 & 32.8 \\
\hline SP-23-17-712 & 99.8 & 108 & 111 & 18.1 & 251 & -- & 339 & 4.3 & 2.06 & 56.4 \\
\hline SP-23-25-904 & 21.2 & 35.8 & 119 & 10.6 & 92.9 & -- & 50.7 & 7.0 & .25 & 49.4 \\
\hline SR-23-41-502 & 18.9 & 29.4 & 483 & 12.8 & 410 & -- & 285 & 6.0 & 2.02 & 52.2 \\
\hline SY-27-48-611 & 233 & 159 & 236 & 14.2 & 460 & -- & 749 & 1.5 & 4.87 & 49.9 \\
\hline SY-28-42-707 & 95.7 & 26.7 & 87.2 & 8.51 & 139 & -- & 114 & 1.8 & .78 & 32.9 \\
\hline SY-28-58-204 & 51.5 & 37.3 & 86.6 & 2.31 & 114 & -- & 90.1 & 2.4 & .69 & 53.0 \\
\hline UH-07-53-228 & 35.4 & 20.6 & 55.4 & 5.2 & 40.7 & -- & 17.5 & 1.9 & .20 & 32.2 \\
\hline UR-10-19-506 & 20.2 & 12.3 & 88.2 & 4.12 & 27.3 & -- & 13.8 & 1.9 & .07 & 25.1 \\
\hline UR-10-42-204 & 34.0 & 27.6 & 28.0 & 5.74 & 23.3 & -- & 19.8 & 2.0 & .12 & 31.4 \\
\hline UY-06-57-824 & 61.8 & 56.7 & 51.8 & 7.57 & 85.9 & -- & 28.8 & 5.2 & .42 & 82.4 \\
\hline UY-10-07-631 & 33.6 & 43.7 & 45.8 & 6.24 & 51.6 & -- & 8.6 & 5.1 & .10 & 76.4 \\
\hline XT-11-44-605 & 40.5 & 33.3 & 42.0 & 7.40 & 25.6 & .001 & 22.2 & 2.8 & .12 & 55.2 \\
\hline XY-24-45-502 & 116 & 93.3 & 103 & 17.6 & 370 & -- & 209 & 4.3 & 1.69 & 49.4 \\
\hline XY-24-47-207 & 70.9 & 155 & 211 & 29.1 & 354 & -- & 308 & 7.5 & 1.74 & 63.5 \\
\hline$X Y-24-62-801$ & 57.3 & 82.5 & 82.1 & 18.5 & 196 & -- & 178 & 4.1 & 1.36 & 45.4 \\
\hline ZT-24-43-202 & 49.5 & 43.9 & 59.8 & $<.09$ & 71.8 & -- & 49.8 & 4.0 & .48 & 44.0 \\
\hline ZT-24-50-602 & 111 & 113 & 197 & 17.7 & 318 & -- & 45.0 & 8.3 & .46 & 51.6 \\
\hline ZT-25-40-804 & 61.3 & 28.2 & 47.9 & 3.56 & 122 & -- & 56.5 & 1.8 & .53 & 46.1 \\
\hline
\end{tabular}


Appendix 3. Nutrients and dissolved organic carbon concentrations in water sampled from primarily domestic wells screened in the southern High Plains aquifer, Texas and New Mexico, 2001

[In milligrams per liter; <, not detected at this reporting level; --, not measured]

\begin{tabular}{|c|c|c|c|c|c|c|c|c|}
\hline $\begin{array}{c}\text { State } \\
\text { well no. }\end{array}$ & $\begin{array}{c}\text { Sample } \\
\text { date }\end{array}$ & $\begin{array}{l}\text { Nitrite } \\
\text { as N }\end{array}$ & $\begin{array}{c}\text { Nitrite + } \\
\text { nitrate } \\
\text { as N }\end{array}$ & $\begin{array}{l}\text { Ammonia } \\
\text { as N }\end{array}$ & $\begin{array}{c}\text { Ammonia + } \\
\text { organic nitrogen } \\
\text { as } N\end{array}$ & $\begin{array}{c}\text { Phosphorus, } \\
\text { total } \\
\text { as } \mathrm{P}\end{array}$ & $\begin{array}{l}\text { Phosphate, } \\
\text { ortho } \\
\text { as P }\end{array}$ & $\begin{array}{l}\text { Carbon, } \\
\text { organic, } \\
\text { dissolved }\end{array}$ \\
\hline NM03N.36E.28.411 & $08 / 24 / 2001$ & $<0.006$ & 1.83 & $<0.04$ & $<0.1$ & 0.008 & $<0.02$ & 0.49 \\
\hline NM05N.34E.36.244 & $09 / 23 / 2001$ & $<.006$ & 2.31 & $<.04$ & $<.1$ & $<.006$ & $<.02$ & $<.3$ \\
\hline NM13S.38E.14.3333A & $09 / 25 / 2001$ & $<.006$ & .97 & $<.04$ & $<.1$ & $<.006$ & $<.02$ & .61 \\
\hline NM15S.38E.14.211 & $08 / 11 / 2001$ & $<.006$ & 11.6 & $<.04$ & .13 & $<.006$ & $<.02$ & 1.4 \\
\hline NM01N.36E.21.233 & $09 / 23 / 2001$ & $<.006$ & 1.38 & $<.04$ & $<.1$ & $<.006$ & $<.02$ & .37 \\
\hline NM02S.36E.17.231 & $08 / 24 / 2001$ & $<.006$ & 5.31 & $<.04$ & $<.1$ & $<.006$ & $<.02$ & 1.2 \\
\hline AB-27-29-905 & $08 / 13 / 2001$ & $<.006$ & 2.11 & $<.04$ & .11 & $<.006$ & $<.02$ & $<.3$ \\
\hline AR-25-08-603 & $09 / 22 / 2001$ & $<.006$ & 3.71 & $<.04$ & $<.1$ & $<.006$ & $<.02$ & $<.3$ \\
\hline BL-11-38-925 & $08 / 19 / 2001$ & $<.006$ & .621 & $<.04$ & $<.1$ & $<.006$ & $<.02$ & 3.1 \\
\hline DD-10-30-803 & $09 / 21 / 2001$ & $<.006$ & 8.31 & $<.04$ & .11 & $<.006$ & $<.02$ & 1 \\
\hline DP-24-19-405 & $09 / 24 / 2001$ & $<.006$ & 3.02 & $<.04$ & $<.1$ & $<.006$ & $<.02$ & 1.6 \\
\hline DP-24-20-705 & $09 / 24 / 2001$ & $<.006$ & .301 & $<.04$ & $<.1$ & $<.006$ & $<.02$ & 1.2 \\
\hline HK-23-14-404 & $08 / 18 / 2001$ & $<.006$ & .615 & $<.04$ & $<.1$ & $<.006$ & $<.02$ & .44 \\
\hline HK-23-29-104 & $09 / 18 / 2001$ & $<.006$ & 11.5 & $<.04$ & .11 & $<.006$ & $<.02$ & .99 \\
\hline HS-28-09-808 & $08 / 16 / 2001$ & $<.006$ & 5.99 & $<.04$ & .12 & .007 & $<.02$ & 1.8 \\
\hline HS-28-27-411 & $08 / 15 / 2001$ & $<.006$ & 2.57 & $<.04$ & $<.1$ & $<.006$ & $<.02$ & .58 \\
\hline HT-10-13-345 & $08 / 21 / 2001$ & $<.006$ & 2.94 & $<.04$ & $<.1$ & $<.006$ & $<.02$ & .44 \\
\hline HT-10-13-640 & $09 / 21 / 2001$ & $<.006$ & 4.83 & $<.04$ & $<.1$ & $<.006$ & $<.02$ & .47 \\
\hline JW-23-08-101 & $09 / 18 / 2001$ & $<.006$ & .937 & $<.04$ & $<.1$ & $<.006$ & $<.02$ & $<.3$ \\
\hline KD-26-24-203 & 08/13/2001 & $<.006$ & 3.03 & $<.04$ & $<.1$ & $<.006$ & $<.02$ & $<.3$ \\
\hline KD-27-01-807 & $08 / 12 / 2001$ & $<.006$ & 4.44 & $<.04$ & $<.1$ & $<.006$ & $<.02$ & 1.6 \\
\hline KD-27-19-518 & 08/13/2001 & $<.006$ & 8.66 & $<.04$ & .11 & $<.006$ & $<.02$ & 1.2 \\
\hline KD-27-30-103 & $08 / 14 / 2001$ & $<.006$ & 4.02 & $<.04$ & .27 & $<.006$ & $<.02$ & 3.4 \\
\hline KY-11-43-805 & $08 / 25 / 2001$ & .012 & 2.66 & $<.04$ & $<.1$ & .009 & $<.02$ & .78 \\
\hline KY-11-49-207 & $09 / 20 / 2001$ & $<.006$ & 1.18 & $<.04$ & $<.1$ & $<.006$ & $<.02$ & .65 \\
\hline KY-23-03-904 & $09 / 19 / 2001$ & $<.006$ & 4.75 & $<.04$ & $<.1$ & $<.006$ & $<.02$ & .63 \\
\hline KY-23-10-304 & $09 / 19 / 2001$ & $<.006$ & .578 & $<.04$ & $<.1$ & .031 & .025 & $<.3$ \\
\hline PB-28-37-307 & $09 / 26 / 2001$ & $<.006$ & 13.7 & $<.04$ & $<.1$ & $<.006$ & $<.02$ & 1.0 \\
\hline RU-10-52-107 & $09 / 22 / 2001$ & $<.006$ & .179 & $<.04$ & $<.1$ & $<.006$ & $<.02$ & $<.3$ \\
\hline RU-10-55-407 & $08 / 26 / 2001$ & $<.006$ & 7.54 & $<.04$ & $<.1$ & $<.006$ & $<.02$ & .41 \\
\hline SP-23-17-712 & 08/10/2001 & $<.006$ & 12.6 & $<.04$ & $<.1$ & $<.006$ & $<.02$ & .88 \\
\hline SP-23-25-904 & $08 / 17 / 2001$ & $<.006$ & 2.13 & $<.04$ & $<.1$ & .014 & $<.02$ & .83 \\
\hline SR-23-41-502 & $08 / 17 / 2001$ & $<.006$ & 7.97 & $<.04$ & .17 & .047 & .038 & 2.2 \\
\hline SY-27-48-611 & $08 / 14 / 2001$ & $<.006$ & 19.5 & $<.04$ & .31 & $<.006$ & $<.02$ & 3.0 \\
\hline SY-28-42-707 & $08 / 15 / 2001$ & $<.006$ & 7.95 & $<.04$ & $<.1$ & .009 & $<.02$ & .58 \\
\hline SY-28-58-204 & $09 / 26 / 2001$ & $<.006$ & 5.99 & $<.04$ & $<.1$ & $<.006$ & $<.02$ & $<.3$ \\
\hline UH-07-53-228 & $08 / 21 / 2001$ & $<.006$ & 4.37 & $<.04$ & $<.1$ & $<.006$ & $<.02$ & 2.1 \\
\hline UR-10-19-506 & $08 / 22 / 2001$ & $<.006$ & .995 & $<.04$ & $<.1$ & $<.006$ & $<.02$ & 3.2 \\
\hline UR-10-42-204 & $08 / 22 / 2001$ & $<.006$ & 2.44 & $<.04$ & $<.1$ & $<.006$ & $<.02$ & .77 \\
\hline UY-06-57-824 & $08 / 20 / 2001$ & $<.006$ & 13.8 & $<.04$ & .15 & .010 & $<.02$ & 1.7 \\
\hline UY-10-07-631 & $08 / 20 / 2001$ & $<.006$ & .216 & $<.04$ & $<.1$ & $<.006$ & $<.02$ & .60 \\
\hline XT-11-44-605 & $08 / 25 / 2001$ & $<.006$ & .912 & $<.04$ & $<.1$ & .009 & $<.02$ & .40 \\
\hline $\mathrm{XY}-24-45-502$ & 08/07/2001 & $<.006$ & 8.07 & $<.04$ & .11 & $<.006$ & $<.02$ & 1.4 \\
\hline XY-24-47-207 & $08 / 16 / 2001$ & $<.006$ & 9.65 & $<.04$ & .15 & .011 & $<.02$ & 1.9 \\
\hline $\mathrm{XY}-24-62-801$ & 08/08/2001 & $<.006$ & 1.64 & $<.04$ & $<.1$ & $<.006$ & $<.02$ & .93 \\
\hline ZT-24-43-202 & $08 / 12 / 2001$ & $<.006$ & .686 & $<.04$ & $<.1$ & .009 & $<.02$ & $<.3$ \\
\hline ZT-24-50-602 & $08 / 11 / 2001$ & $<.006$ & 1.88 & $<.04$ & .18 & .013 & $<.02$ & 1.3 \\
\hline ZT-25-40-804 & $09 / 25 / 2001$ & $<.006$ & 1.68 & $<.04$ & $<.1$ & $<.006$ & $<.02$ & -- \\
\hline
\end{tabular}


Appendix 4. Trace element concentrations in water sampled from primarily domestic wells screened in the southern High Plains aquifer, Texas and New Mexico, 2001

[In micrograms per liter, <, less than; E, estimated; --, not measured]

\begin{tabular}{|c|c|c|c|c|c|c|c|c|c|c|c|c|}
\hline $\begin{array}{c}\text { State } \\
\text { well no. }\end{array}$ & $\begin{array}{l}\text { Sample } \\
\text { date }\end{array}$ & $\begin{array}{l}\text { Alumi- } \\
\text { num }\end{array}$ & $\begin{array}{l}\text { Anti- } \\
\text { mony }\end{array}$ & Arsenic & Barium & $\begin{array}{l}\text { Beryll- } \\
\text { ium }\end{array}$ & Boron & $\begin{array}{l}\text { Cad- } \\
\text { mium }\end{array}$ & $\begin{array}{l}\text { Chro- } \\
\text { mium }\end{array}$ & Cobalt & Copper & Iron \\
\hline NM03N.36E.28.411 & $08 / 24 / 2001$ & $<1$ & $<0.05$ & 3.4 & 76.2 & $<0.06$ & 109 & $<0.04$ & $<4$ & 0.04 & 0.9 & $<10$ \\
\hline NM05N.34E.36.244 & $09 / 23 / 2001$ & $<1$ & $<.05$ & 2.9 & 83.7 & $<.06$ & 116 & $<.04$ & $<4$ & .04 & 2.1 & $<10$ \\
\hline NM13S.38E.14.3333A & $09 / 25 / 2001$ & $<1$ & $<.2$ & 8.6 & 37.4 & $<.06$ & 154 & $<.04$ & $<.8$ & .10 & 1.4 & $<10$ \\
\hline NM15S.38E.14.211 & $08 / 11 / 2001$ & $<1$ & $<.2$ & 4.6 & 57.7 & $<.06$ & 235 & $<.04$ & $<.8$ & .18 & 1.2 & $<10$ \\
\hline NM01N.36E.21.233 & $09 / 23 / 2001$ & $<1$ & $<.05$ & 6.8 & 52.6 & $<.06$ & 123 & $<.04$ & $<.8$ & .04 & .9 & $<10$ \\
\hline NM02S.36E.17.231 & $08 / 24 / 2001$ & $<1$ & $<.2$ & 4.0 & 34.1 & $<.06$ & 80 & $<.04$ & $<.8$ & .09 & 1.5 & $<10$ \\
\hline AB-27-29-905 & $08 / 13 / 2001$ & $<1$ & $<.2$ & 48.1 & 39.7 & $<.06$ & 275 & $<.2$ & $<4$ & .05 & 2.2 & $<10$ \\
\hline AR-25-08-603 & $09 / 22 / 2001$ & $<1$ & $<.05$ & 7.1 & 71.8 & $<.06$ & 179 & $<.04$ & $<4$ & .05 & 1.3 & $<10$ \\
\hline BL-11-38-925 & $08 / 19 / 2001$ & $<1$ & $<.2$ & 9.0 & 34.9 & $<.06$ & 604 & $<.07$ & $<4$ & .03 & 2.2 & $<10$ \\
\hline DD-10-30-803 & $09 / 21 / 2001$ & $<1$ & $<.2$ & 2.9 & 128 & $<.06$ & 127 & $<.04$ & $<4$ & .12 & 1.3 & $<10$ \\
\hline DP-24-19-405 & $09 / 24 / 2001$ & $<1$ & $<.2$ & 4.9 & 29.3 & $<.06$ & 262 & $<.04$ & $<4$ & .12 & 2.8 & $<30$ \\
\hline DP-24-20-705 & $09 / 24 / 2001$ & $<1$ & $<.2$ & 21.3 & 36.8 & $<.06$ & 302 & $<.04$ & $<.8$ & .70 & 3.5 & $<10$ \\
\hline HK-23-14-404 & $08 / 18 / 2001$ & $<1$ & $<.05$ & 9.3 & 57.9 & $<.06$ & 382 & $<.04$ & $<4$ & .03 & .6 & $<10$ \\
\hline HK-23-29-104 & $09 / 18 / 2001$ & $<1$ & $<.2$ & 6.5 & 192 & $<.06$ & 364 & $<.04$ & $<4$ & .16 & 2.8 & $<10$ \\
\hline HS-28-09-808 & 08/16/2001 & $<1$ & $<.2$ & 20.0 & 30.7 & $<.06$ & 408 & $<.07$ & $<4$ & .19 & 7.1 & $<10$ \\
\hline HS-28-27-411 & $08 / 15 / 2001$ & $<1$ & $<.2$ & 2.8 & 382 & $<.06$ & 151 & $<.07$ & $<.8$ & .16 & 1.2 & $<10$ \\
\hline HT-10-13-345 & $08 / 21 / 2001$ & $<1$ & $<.05$ & 2.2 & 81.1 & $<.06$ & 183 & $<.04$ & $<4$ & .05 & .4 & $<10$ \\
\hline HT-10-13-640 & $09 / 21 / 2001$ & $<1$ & $<.05$ & 2.8 & 44.5 & $<.06$ & 161 & $<.04$ & $<4$ & .09 & .9 & $<30$ \\
\hline JW-23-08-101 & 09/18/2001 & $<1$ & $<.2$ & 7.9 & 79.4 & $<.06$ & 255 & $<.04$ & $<4$ & .04 & .8 & $<10$ \\
\hline KD-26-24-203 & 08/13/2001 & $<1$ & $<.2$ & 11.4 & 57.5 & $<.06$ & 123 & $<.2$ & $<.8$ & .06 & $<.2$ & $<10$ \\
\hline KD-27-01-807 & $08 / 12 / 2001$ & $<1$ & $<.2$ & 6.5 & 47.6 & $<.06$ & 222 & $<.04$ & $<.8$ & .18 & 2.7 & $<30$ \\
\hline KD-27-19-518 & $08 / 13 / 2001$ & $<1$ & $<.2$ & 13.8 & 85.1 & $<.06$ & 293 & $<.04$ & $<.8$ & .12 & 1.2 & $<10$ \\
\hline KD-27-30-103 & $08 / 14 / 2001$ & $<5$ & $<.2$ & 13.1 & 47.3 & $<.1$ & 675 & $<.07$ & $<.8$ & .39 & 8.2 & $<30$ \\
\hline KY-11-43-805 & $08 / 25 / 2001$ & $<1$ & $<.2$ & 4.3 & 93.0 & $<.06$ & 231 & .22 & $<.8$ & .47 & 2.2 & $<10$ \\
\hline KY-11-49-207 & 09/20/2001 & $<1$ & $<.05$ & 3.1 & 98.8 & $<.06$ & 187 & $<.04$ & $<4$ & .05 & 1.0 & $<10$ \\
\hline KY-23-03-904 & 09/19/2001 & $<1$ & $<.2$ & 7.4 & 111 & $<.06$ & 378 & $<.04$ & $<4$ & .07 & 1.3 & $<10$ \\
\hline KY-23-10-304 & 09/19/2001 & $<1$ & $<.2$ & 6.0 & 108 & $<.06$ & 424 & $<.04$ & $<4$ & .05 & .7 & $<10$ \\
\hline PB-28-37-307 & $09 / 26 / 2001$ & $<1$ & $<.2$ & 5.6 & 83.3 & $<.06$ & 223 & $<.04$ & $<4$ & .18 & 1.4 & $<10$ \\
\hline RU-10-52-107 & $09 / 22 / 2001$ & $<1$ & $<.05$ & 4.7 & 41.8 & $<.06$ & 467 & $<.04$ & $<.8$ & .16 & 3.0 & $<30$ \\
\hline RU-10-55-407 & $08 / 26 / 2001$ & $<1$ & $<.05$ & 1.7 & 157 & $<.06$ & 152 & $<.07$ & $<.8$ & .08 & 1.6 & $<10$ \\
\hline SP-23-17-712 & 08/10/2001 & $<1$ & $<.2$ & 7.2 & 87.3 & $<.06$ & 482 & $<.04$ & $<.8$ & .12 & 1.2 & $<10$ \\
\hline SP-23-25-904 & $08 / 17 / 2001$ & $<1$ & $<.2$ & 11.4 & 28.1 & $<.06$ & 443 & $<.2$ & $<.8$ & .04 & 2.7 & $<10$ \\
\hline SR-23-41-502 & $08 / 17 / 2001$ & $<1$ & $<.2$ & 107 & 56.7 & $<.06$ & 1,630 & $<.2$ & $<4$ & .09 & 10 & $<30$ \\
\hline SY-27-48-611 & $08 / 14 / 2001$ & $<2$ & $<.2$ & 11.3 & 24.1 & $<.1$ & 893 & $<.07$ & $<.8$ & .41 & 6.0 & $<30$ \\
\hline SY-28-42-707 & $08 / 15 / 2001$ & $<1$ & $<.2$ & 3.8 & 63.9 & $<.06$ & 337 & $<.07$ & $<.8$ & .15 & 2.7 & $<10$ \\
\hline SY-28-58-204 & $09 / 26 / 2001$ & $<1$ & $<.2$ & 23.1 & 35.8 & $<.06$ & 266 & $<.04$ & $<4$ & .07 & 1.4 & $<10$ \\
\hline UH-07-53-228 & $08 / 21 / 2001$ & $<1$ & $<.2$ & 2.0 & 80.7 & $<.06$ & 197 & $<.04$ & 4.9 & .04 & .7 & $<10$ \\
\hline UR-10-19-506 & $08 / 22 / 2001$ & $<1$ & $<.05$ & 1.7 & 62.5 & $<.06$ & 189 & $<.07$ & $<4$ & .04 & .3 & $<30$ \\
\hline UR-10-42-204 & $08 / 22 / 2001$ & $<1$ & $<.2$ & 4.0 & 169 & $<.06$ & 122 & $<.04$ & $<4$ & .04 & .4 & $<30$ \\
\hline UY-06-57-824 & $08 / 20 / 2001$ & $<5$ & $<.2$ & 3.1 & 106 & $<.06$ & 73 & $<.2$ & $<.8$ & .13 & E.9 & $<10$ \\
\hline UY-10-07-631 & $08 / 20 / 2001$ & $<1$ & $<.2$ & 5.2 & 55.1 & $<.06$ & 219 & $<.07$ & $<.8$ & .04 & .9 & $<30$ \\
\hline XT-11-44-605 & $08 / 25 / 2001$ & $<1$ & $<.2$ & 4.2 & 111 & $<.06$ & 205 & $<.2$ & $<.8$ & .05 & 1.1 & $<10$ \\
\hline $\mathrm{XY}-24-45-502$ & 08/07/2001 & -- & -- & -- & -- & -- & -- & -- & -- & -- & -- & $<10$ \\
\hline$X Y-24-47-207$ & $08 / 16 / 2001$ & $<1$ & $<.2$ & 11.6 & 54.7 & $<.06$ & 963 & $<.07$ & $<.8$ & .79 & 10 & $<30$ \\
\hline$X Y-24-62-801$ & $08 / 08 / 2001$ & $<1$ & $<.2$ & 46.9 & 85.5 & $<.06$ & 321 & $<.04$ & $<.8$ & .30 & 1 & $<10$ \\
\hline ZT-24-43-202 & $08 / 12 / 2001$ & $<1$ & $<.2$ & 12.8 & 63.3 & $<.06$ & 217 & $<.04$ & $<.8$ & .05 & $<.2$ & $<10$ \\
\hline ZT-24-50-602 & $08 / 11 / 2001$ & $<1$ & $<.2$ & 33.1 & 36.7 & $<.06$ & 564 & $<.07$ & $<4$ & .16 & 16 & $<30$ \\
\hline ZT-25-40-804 & $09 / 25 / 2001$ & 6 & $<.2$ & 6.7 & 26.8 & $<.06$ & 142 & $<.04$ & $<.8$ & .14 & 5.4 & 60 \\
\hline
\end{tabular}


Appendix 4. Trace element concentrations in water sampled from primarily domestic wells screened in the southern High Plains aquifer, Texas and New Mexico, 2001—Continued

\begin{tabular}{|c|c|c|c|c|c|c|c|c|c|c|c|c|}
\hline $\begin{array}{c}\text { State } \\
\text { well no. }\end{array}$ & Lead & Lithium & $\begin{array}{c}\text { Man- } \\
\text { ganese }\end{array}$ & $\begin{array}{c}\text { Moly- } \\
\text { bdenum }\end{array}$ & Nickel & Selenium & Silver & Strontium & Thallium & Uranium & Vanadium & Zinc \\
\hline NM03N.36E.28.411 & 0.26 & 52.6 & $<0.1$ & 4.8 & $<0.06$ & 2.1 & $<1$ & 837 & $<0.04$ & 6.09 & 26.0 & 3 \\
\hline NM05N.34E.36.244 & .73 & 59.1 & $<.1$ & 1.6 & $<.06$ & 1.3 & $<1$ & 834 & $<.2$ & 5.36 & 20.5 & 251 \\
\hline NM13S.38E.14.3333A & $<.08$ & 47.5 & $<.5$ & 4.6 & $<.3$ & 7.1 & $<1$ & 957 & $<.04$ & 3.17 & 48.1 & 2 \\
\hline NM15S.38E.14.211 & $<.08$ & 54.2 & $<.5$ & 1.6 & $<.3$ & 7.2 & $<1$ & 1,450 & $<.04$ & 9.50 & 31.7 & 2 \\
\hline NM01N.36E.21.233 & $<.2$ & 85 & $<.1$ & 3.5 & $<.06$ & 1.4 & $<1$ & 1,010 & $<.04$ & 5.84 & 47.3 & 19 \\
\hline NM02S.36E.17.231 & $<.08$ & 26.4 & $<.1$ & .5 & $<.3$ & 19.2 & $<1$ & 1,040 & $<.04$ & 3.58 & 25.0 & 7 \\
\hline AB-27-29-905 & $<.08$ & 99.4 & $<.5$ & 13.0 & $<.06$ & 6.6 & $<1$ & 2,710 & $<.04$ & 5.93 & 155 & 12 \\
\hline AR-25-08-603 & $<.08$ & 72.9 & $<.1$ & 8.3 & $<.06$ & 3.5 & $<1$ & 964 & $<.04$ & 2.49 & 44.7 & 3 \\
\hline BL-11-38-925 & .34 & 204 & $<.1$ & 23.4 & $<.06$ & 8.6 & $<1$ & 1,650 & $<.04$ & 14.9 & 40.0 & 7 \\
\hline DD-10-30-803 & .33 & 70.4 & $<.5$ & 2.5 & $<.06$ & 5.3 & $<1$ & 1,760 & $<.04$ & 4.86 & 14.9 & 107 \\
\hline DP-24-19-405 & $<.08$ & 129 & 7.7 & 2.5 & $<.06$ & 24.7 & $<1$ & 2,410 & $<.04$ & 6.63 & 37.6 & $<1$ \\
\hline DP-24-20-705 & $<.08$ & 154 & 671 & 4.6 & 2.19 & 1.5 & $<1$ & 3,360 & $<.2$ & 11.3 & 40.6 & 2 \\
\hline HK-23-14-404 & .44 & 72.7 & $<.1$ & 8.3 & $<.06$ & 6.7 & $<1$ & 1,070 & $<.04$ & 11.1 & 45.9 & 133 \\
\hline HK-23-29-104 & $<.2$ & 162 & 1.0 & 3.1 & $<.06$ & 13.3 & $<1$ & 3,350 & $<.04$ & 9.39 & 26.9 & 49 \\
\hline HS-28-09-808 & $<.08$ & 226 & $<.5$ & 6.0 & $<.06$ & 32.4 & $<1$ & 6,940 & $<.04$ & 15.0 & 82.6 & 5 \\
\hline HS-28-27-411 & .64 & 40.7 & $<.5$ & .5 & $<.3$ & .8 & $<1$ & 1,100 & $<.04$ & 13.1 & 18.7 & 114 \\
\hline HT-10-13-345 & $<.08$ & 65.7 & .9 & 5.1 & $<.06$ & 2.8 & $<1$ & 1,120 & $<.04$ & 5.89 & 14.0 & 70 \\
\hline HT-10-13-640 & $<.2$ & 123 & $<.1$ & 2.0 & $<.06$ & 5.7 & $<1$ & 1,330 & $<.04$ & 9.83 & 18.2 & 56 \\
\hline JW-23-08-101 & $<.2$ & 92.5 & $<.1$ & 8.8 & $<.06$ & 4.1 & $<1$ & 999 & $<.04$ & 8.48 & 37.2 & 21 \\
\hline KD-26-24-203 & $<.08$ & 32.3 & $<.1$ & 4.0 & $<.3$ & 4.1 & $<1$ & 597 & $<.04$ & 2.12 & 70.9 & $<1$ \\
\hline KD-27-01-807 & .75 & 58.1 & $<.5$ & 2.1 & $<.3$ & 15.0 & $<1$ & 1,800 & $<.04$ & 5.56 & 38.6 & 2 \\
\hline KD-27-19-518 & $<.08$ & 213 & $<.5$ & 4.4 & $<.1$ & 16.0 & $<1$ & 2,830 & $<.04$ & 6.92 & 94.6 & 15 \\
\hline KD-27-30-103 & $<.2$ & 144 & $<.5$ & 5.0 & $<.3$ & 17.9 & $<2$ & 5,740 & $<.2$ & 15.4 & 54.5 & 5 \\
\hline KY-11-43-805 & 4.55 & 105 & 161 & 4.2 & $<.06$ & 8.4 & $<1$ & 1,490 & $<.04$ & 8.39 & 18.7 & 243 \\
\hline KY-11-49-207 & $<.2$ & 80.3 & $<.5$ & 3.5 & $<.06$ & 1.1 & $<1$ & 831 & $<.04$ & 6.73 & 17.8 & 23 \\
\hline KY-23-03-904 & $<.2$ & 99.2 & .6 & 6.2 & $<.06$ & 9.4 & $<1$ & 1,460 & $<.04$ & 6.92 & 29.1 & 36 \\
\hline KY-23-10-304 & $<.08$ & 63.6 & .9 & 6.4 & $<.06$ & 1.3 & $<1$ & 1,160 & $<.04$ & 9.11 & 28.2 & $<1$ \\
\hline PB-28-37-307 & $<.08$ & 134 & $<.5$ & 1.5 & .70 & 8.7 & $<1$ & 4,000 & $<.04$ & 7.51 & 29.3 & $<1$ \\
\hline RU-10-52-107 & $<.08$ & 167 & 270 & 10.3 & $<.06$ & .8 & $<1$ & 1,840 & $<.04$ & 5.13 & 34.3 & 10 \\
\hline RU-10-55-407 & .26 & 73.9 & $<.5$ & 4.4 & $<.06$ & 3.2 & $<1$ & 1,410 & $<.04$ & 6.95 & 12.8 & 16 \\
\hline SP-23-17-712 & $<.08$ & 147 & $<.5$ & 4.7 & $<.3$ & 24.2 & $<1$ & 5,310 & $<.04$ & 18.2 & 43.7 & 2 \\
\hline SP-23-25-904 & $<.08$ & 83.4 & $<.5$ & 46.4 & $<.06$ & 6.2 & $<1$ & 1,660 & $<.04$ & 14.3 & 115 & 2 \\
\hline SR-23-41-502 & $<.08$ & 57.5 & $<.5$ & 15.0 & $<.06$ & 38.7 & $<1$ & 1,210 & $<.2$ & 5.30 & 170 & 4 \\
\hline SY-27-48-611 & $<.2$ & 129 & .6 & 2.9 & $<.3$ & 34.6 & $<2$ & 9,190 & $<.08$ & 17.1 & 49.9 & 6 \\
\hline SY-28-42-707 & $<.08$ & 61.9 & $<.5$ & 4.9 & $<.3$ & 8.6 & $<1$ & 2,030 & $<.2$ & 6.24 & 18.6 & 3 \\
\hline SY-28-58-204 & $<.08$ & 91.3 & $<.5$ & 13.4 & $<.2$ & 8.7 & $<1$ & 2,050 & $<.04$ & 8.55 & 103 & 2 \\
\hline UH-07-53-228 & $<.2$ & 53 & $<.5$ & 3.3 & $<.06$ & 7.6 & $<1$ & 922 & $<.04$ & 6.11 & 11.3 & 18 \\
\hline UR-10-19-506 & $<.08$ & 44 & 5.4 & 6.1 & $<.3$ & 2.3 & $<1$ & 565 & $<.04$ & 6.20 & 9.4 & 89 \\
\hline UR-10-42-204 & $<.08$ & 60.8 & $<.1$ & 3.6 & $<.06$ & 2.2 & $<1$ & 1,080 & $<.04$ & 6.08 & 24.6 & 2 \\
\hline UY-06-57-824 & E. 28 & 576 & $<.5$ & 4.7 & .43 & 2.4 & $<5$ & 2,090 & $<.2$ & 12.6 & 16.6 & 9 \\
\hline UY-10-07-631 & $<.2$ & 127 & 1.9 & 5.7 & $<.06$ & .6 & $<1$ & 1,420 & $<.04$ & 15.1 & 31.9 & 34 \\
\hline XT-11-44-605 & .28 & 105 & 1.4 & 5.7 & $<.06$ & 3.5 & $<1$ & 1,130 & $<.04$ & 5.42 & 17.2 & 28 \\
\hline$X Y-24-45-502$ & -- & -- & -- & -- & -- & -- & -- & -- & -- & -- & -- & -- \\
\hline XY-24-47-207 & 1.98 & 163 & $<.5$ & 9.1 & .42 & 15.4 & $<1$ & 5,530 & $<.2$ & 12.1 & 92.4 & 7 \\
\hline XY-24-62-801 & $<.08$ & 132 & 382 & 4.0 & $<.3$ & 3.3 & $<1$ & 9,340 & $<.04$ & .49 & 98.5 & 2 \\
\hline ZT-24-43-202 & $<.08$ & 159 & $<.5$ & 2.0 & 1.39 & 1.9 & $<1$ & 2,230 & $<.04$ & 13.7 & 65.7 & $<1$ \\
\hline ZT-24-50-602 & $<.2$ & 145 & $<.5$ & 22.4 & $<.3$ & 20.9 & $<1$ & 6,680 & $<.04$ & 14.8 & 190 & 5 \\
\hline ZT-25-40-804 & $<.2$ & 44.3 & 5.0 & 5.2 & $<.06$ & 5.3 & $<1$ & 1,010 & $<.04$ & 3.53 & 37.9 & 75 \\
\hline
\end{tabular}


Appendix 5. Radon and tritium concentrations in water sampled from primarily domestic wells screened in the southern High Plains aquifer, Texas and New Mexico, 2001

[In picocuries per liter; --, not measured]

\begin{tabular}{|c|c|c|c|}
\hline State well no. & Sample date & Radon-222 & Tritium \\
\hline NM03N.36E.28.411 & $08 / 24 / 2001$ & 1,440 & $\overline{--}$ \\
\hline NM05N.34E.36.244 & $09 / 23 / 2001$ & 478 & $<1$ \\
\hline NM13S.38E.14.3333A & $09 / 25 / 2001$ & 229 & $<1$ \\
\hline NM15S.38E.14.211 & $08 / 11 / 2001$ & 427 & -- \\
\hline NM01N.36E.21.233 & $09 / 23 / 2001$ & 320 & $<1$ \\
\hline NM02S.36E.17.231 & $08 / 24 / 2001$ & 202 & -- \\
\hline AB-27-29-905 & $08 / 13 / 2001$ & 1,040 & -- \\
\hline AR-25-08-603 & $09 / 22 / 2001$ & 432 & $<1$ \\
\hline BL-11-38-925 & $08 / 19 / 2001$ & 521 & $<1$ \\
\hline DD-10-30-803 & $09 / 21 / 2001$ & 268 & -- \\
\hline DP-24-19-405 & $09 / 24 / 2001$ & 546 & -- \\
\hline DP-24-20-705 & $09 / 24 / 2001$ & 477 & -- \\
\hline HK-23-14-404 & $08 / 18 / 2001$ & 406 & $<1$ \\
\hline HK-23-29-104 & $09 / 18 / 2001$ & 296 & -- \\
\hline HS-28-09-808 & $08 / 16 / 2001$ & 249 & -- \\
\hline HS-28-27-411 & $08 / 15 / 2001$ & 314 & -- \\
\hline HT-10-13-345 & $08 / 21 / 2001$ & 222 & $<1$ \\
\hline HT-10-13-640 & $09 / 21 / 2001$ & 290 & -- \\
\hline JW-23-08-101 & $09 / 18 / 2001$ & 330 & -- \\
\hline KD-26-24-203 & 08/13/2001 & 454 & $<1$ \\
\hline KD-27-01-807 & $08 / 12 / 2001$ & 468 & -- \\
\hline KD-27-19-518 & $08 / 13 / 2001$ & 336 & -- \\
\hline KD-27-30-103 & $08 / 14 / 2001$ & 641 & -- \\
\hline KY-11-43-805 & $08 / 25 / 2001$ & 351 & -- \\
\hline KY-11-49-207 & $09 / 20 / 2001$ & -- & 3.2 \\
\hline KY-23-03-904 & $09 / 19 / 2001$ & 771 & -- \\
\hline KY-23-10-304 & $09 / 19 / 2001$ & 483 & -- \\
\hline PB-28-37-307 & $09 / 26 / 2001$ & 515 & -- \\
\hline RU-10-52-107 & $09 / 22 / 2001$ & 385 & $<1$ \\
\hline RU-10-55-407 & $08 / 26 / 2001$ & 797 & -- \\
\hline SP-23-17-712 & 08/10/2001 & 407 & -- \\
\hline SP-23-25-904 & $08 / 17 / 2001$ & 254 & -- \\
\hline SR-23-41-502 & $08 / 17 / 2001$ & 545 & -- \\
\hline SY-27-48-611 & $08 / 14 / 2001$ & 802 & -- \\
\hline SY-28-42-707 & $08 / 15 / 2001$ & 271 & -- \\
\hline SY-28-58-204 & $09 / 26 / 2001$ & 717 & -- \\
\hline UH-07-53-228 & $08 / 21 / 2001$ & 418 & -- \\
\hline UR-10-19-506 & $08 / 22 / 2001$ & 219 & $<1$ \\
\hline UR-10-42-204 & $08 / 22 / 2001$ & 635 & -- \\
\hline UY-06-57-824 & $08 / 20 / 2001$ & 345 & -- \\
\hline UY-10-07-631 & $08 / 20 / 2001$ & 806 & $<1$ \\
\hline XT-11-44-605 & $08 / 25 / 2001$ & 439 & -- \\
\hline$X Y-24-45-502$ & 08/07/2001 & 389 & -- \\
\hline$X Y-24-47-207$ & $08 / 16 / 2001$ & 417 & -- \\
\hline XY-24-62-801 & 08/08/2001 & 430 & $<1$ \\
\hline ZT-24-43-202 & $08 / 12 / 2001$ & 439 & $<1$ \\
\hline ZT-24-50-602 & $08 / 11 / 2001$ & 534 & 6.1 \\
\hline ZT-25-40-804 & $09 / 25 / 2001$ & -- & $<1$ \\
\hline
\end{tabular}


Appendix 6. Pesticide concentrations in water sampled from primarily domestic wells screened in the southern High Plains, Texas and New Mexico, 2001

[Other compound name (if applicable) listed below compound name; concentrations are in micrograms per liter, <, less than; E, estimated]

\begin{tabular}{|c|c|c|c|c|c|c|c|c|c|c|c|}
\hline $\begin{array}{c}\text { State } \\
\text { well no. }\end{array}$ & $\begin{array}{l}\text { Sample } \\
\text { date }\end{array}$ & 2,4-D & $\begin{array}{c}2,4-D \\
\text { methyl } \\
\text { ester }\end{array}$ & 2,4-DB & $\begin{array}{l}3 \text { (4-chloro- } \\
\text { phenyl)-1- } \\
\text { methyl urea }\end{array}$ & $\begin{array}{l}\text { Aceto- } \\
\text { chlor }\end{array}$ & $\begin{array}{l}\text { Acifluor- } \\
\text { fen }\end{array}$ & Alachlor & Aldicarb & $\begin{array}{l}\text { Aldicarb } \\
\text { sulfone }\end{array}$ & $\begin{array}{l}\text { Aldicarb } \\
\text { sulfoxide }\end{array}$ \\
\hline NM03N.36E.28.411 & $08 / 24 / 01$ & $<0.02$ & $<0.009$ & $<0.02$ & $<0.0242$ & $<0.004$ & $<0.01$ & $<0.002$ & $<0.04$ & $<0.02$ & $<0.01$ \\
\hline NM05N.34E.36.244 & 09/23/01 & $<.02$ & $<.009$ & $<.02$ & $<.0242$ & $<.004$ & $<.01$ & $<.002$ & $<.04$ & $<.02$ & $<.01$ \\
\hline NM13S.38E.14.3333A & $09 / 25 / 01$ & $<.02$ & $<.009$ & $<.02$ & $<.0242$ & $<.004$ & $<.01$ & $<.002$ & $<.04$ & $<.02$ & $<.01$ \\
\hline NM15S.38E.14.211 & 08/11/01 & $<.02$ & $<.009$ & $<.02$ & $<.0011$ & $<.004$ & $<.01$ & $<.002$ & $<.04$ & $<.02$ & $<.01$ \\
\hline NM01N.36E.21.233 & 09/23/01 & $<.02$ & $<.009$ & $<.02$ & $<.0242$ & $<.004$ & $<.01$ & $<.002$ & $<.04$ & $<.02$ & $<.01$ \\
\hline NM02S.36E.17.231 & $08 / 24 / 01$ & $<.02$ & $<.009$ & $<.02$ & $<.0242$ & $<.004$ & $<.01$ & $<.002$ & $<.04$ & $<.02$ & $<.01$ \\
\hline AB-27-29-905 & 08/13/01 & $<.02$ & $<.009$ & $<.02$ & $<.0242$ & $<.004$ & $<.01$ & $<.002$ & $<.04$ & $<.02$ & $<.01$ \\
\hline AR-25-08-603 & $09 / 22 / 01$ & $<.02$ & $<.009$ & $<.02$ & $<.0242$ & $<.004$ & $<.01$ & $<.002$ & $<.04$ & $<.02$ & $<.01$ \\
\hline BL-11-38-925 & 08/19/01 & $<.02$ & $<.009$ & $<.02$ & $<.0242$ & $<.004$ & $<.01$ & $<.002$ & $<.04$ & $<.02$ & $<.01$ \\
\hline DD-10-30-803 & $09 / 21 / 01$ & $<.02$ & $<.009$ & $<.02$ & $<.0242$ & $<.004$ & $<.01$ & $<.002$ & $<.04$ & $<.02$ & $<.01$ \\
\hline DP-24-19-405 & 09/24/01 & $<.02$ & $<.009$ & $<.02$ & $<.0242$ & $<.004$ & $<.01$ & $<.002$ & $<.04$ & $<.02$ & $<.01$ \\
\hline DP-24-20-705 & $09 / 24 / 01$ & $<.02$ & $<.009$ & $<.02$ & $<.0242$ & $<.004$ & $<.01$ & $<.002$ & $<.04$ & $<.0004$ & $<.01$ \\
\hline HK-23-14-404 & 08/18/01 & $<.02$ & $<.009$ & $<.02$ & $<.0242$ & $<.004$ & $<.01$ & $<.002$ & $<.04$ & $<.02$ & $<.01$ \\
\hline HK-23-29-104 & 09/18/01 & $<.02$ & $<.009$ & $<.02$ & $<.0242$ & $<.004$ & $<.01$ & $<.002$ & $<.04$ & $<.02$ & $<.01$ \\
\hline HS-28-09-808 & 08/16/01 & $<.02$ & $<.009$ & $<.02$ & $<.0242$ & $<.004$ & $<.01$ & $<.002$ & $<.04$ & $<.02$ & $<.01$ \\
\hline HS-28-27-411 & $08 / 15 / 01$ & $<.02$ & $<.009$ & $<.02$ & $<.0242$ & $<.004$ & $<.01$ & $<.002$ & $<.04$ & $<.02$ & $<.01$ \\
\hline HT-10-13-345 & $08 / 21 / 01$ & $<.02$ & $<.009$ & $<.02$ & $<.0272$ & $<.004$ & $<.01$ & $<.002$ & $<.04$ & $<.02$ & $<.01$ \\
\hline HT-10-13-640 & $09 / 21 / 01$ & $<.02$ & $<.009$ & $<.02$ & $<.0242$ & $<.004$ & $<.01$ & $<.002$ & $<.04$ & $<.02$ & $<.01$ \\
\hline JW-23-08-101 & 09/18/01 & $<.02$ & $<.009$ & $<.02$ & $<.0242$ & $<.004$ & $<.01$ & $<.002$ & $<.04$ & $<.02$ & $<.01$ \\
\hline KD-26-24-203 & 08/13/01 & $<.02$ & $<.009$ & $<.02$ & $<.0004$ & $<.004$ & $<.01$ & $<.002$ & $<.04$ & $<.02$ & $<.01$ \\
\hline KD-27-01-807 & 08/12/01 & $<.02$ & $<.009$ & $<.02$ & $<.0009$ & $<.004$ & $<.01$ & $<.002$ & $<.04$ & $<.02$ & $<.01$ \\
\hline KD-27-19-518 & 08/13/01 & $<.02$ & $<.009$ & $<.02$ & $<.0015$ & $<.004$ & $<.01$ & $<.002$ & $<.04$ & $<.02$ & $<.01$ \\
\hline KD-27-30-103 & 08/14/01 & $<.02$ & $<.009$ & $<.02$ & $<.0242$ & $<.004$ & $<.01$ & $<.002$ & $<.04$ & $<.02$ & $<.01$ \\
\hline KY-11-43-805 & $08 / 25 / 01$ & $<.02$ & $<.009$ & $<.02$ & $<.0242$ & $<.004$ & $<.01$ & $<.002$ & $<.04$ & $<.02$ & $<.01$ \\
\hline KY-11-49-207 & 09/20/01 & $<.02$ & $<.009$ & $<.02$ & $<.0242$ & $<.004$ & $<.01$ & $<.002$ & $<.04$ & $<.02$ & $<.01$ \\
\hline KY-23-03-904 & 09/19/01 & $<.02$ & $<.009$ & $<.02$ & $<.0242$ & $<.004$ & $<.01$ & $<.002$ & $<.04$ & $<.02$ & $<.01$ \\
\hline KY-23-10-304 & 09/19/01 & $<.02$ & $<.009$ & $<.02$ & $<.0242$ & $<.004$ & $<.01$ & $<.002$ & $<.04$ & $<.02$ & $<.01$ \\
\hline PB-28-37-307 & $09 / 26 / 01$ & $<.02$ & $<.009$ & $<.02$ & $<.0242$ & $<.004$ & $<.01$ & $<.002$ & $<.04$ & $<.02$ & $<.01$ \\
\hline RU-10-52-107 & 09/22/01 & $<.02$ & $<.009$ & $<.02$ & $<.0242$ & $<.004$ & $<.01$ & $<.002$ & $<.04$ & $<.02$ & $<.01$ \\
\hline RU-10-55-407 & 08/26/01 & $<.02$ & $<.009$ & $<.02$ & $<.0242$ & $<.004$ & $<.01$ & $<.002$ & $<.04$ & $<.02$ & $<.01$ \\
\hline SP-23-17-712 & 08/10/01 & $<.02$ & $<.009$ & $<.02$ & $<.0007$ & $<.004$ & $<.01$ & $<.002$ & $<.04$ & $<.02$ & $<.01$ \\
\hline SP-23-25-904 & 08/17/01 & $<.02$ & $<.009$ & $<.02$ & $<.0242$ & $<.004$ & $<.01$ & $<.002$ & $<.04$ & $<.02$ & $<.01$ \\
\hline SR-23-41-502 & 08/17/01 & $<.02$ & $<.009$ & $<.02$ & $<.0242$ & $<.004$ & $<.01$ & $<.002$ & $<.04$ & $<.02$ & $<.01$ \\
\hline SY-27-48-611 & 08/14/01 & $<.02$ & $<.009$ & $<.02$ & $<.0242$ & $<.004$ & $<.01$ & $<.002$ & $<.04$ & $<.02$ & $<.01$ \\
\hline SY-28-42-707 & 08/15/01 & $<.02$ & $<.009$ & $<.02$ & $<.0242$ & $<.004$ & $<.01$ & $<.002$ & $<.04$ & $<.02$ & $<.01$ \\
\hline SY-28-58-204 & $09 / 26 / 01$ & $<.02$ & $<.009$ & $<.02$ & $<.0242$ & $<.004$ & $<.01$ & $<.002$ & $<.04$ & $<.02$ & $<.01$ \\
\hline UH-07-53-228 & $08 / 21 / 01$ & $<.02$ & $<.009$ & $<.02$ & $<.0272$ & $<.004$ & $<.01$ & $<.002$ & $<.04$ & $<.02$ & $<.01$ \\
\hline UR-10-19-506 & $08 / 22 / 01$ & $<.02$ & $<.009$ & $<.02$ & $<.0242$ & $<.004$ & $<.01$ & $<.002$ & $<.04$ & $<.02$ & $<.01$ \\
\hline UR-10-42-204 & 08/22/01 & $<.02$ & $<.009$ & $<.02$ & $<.0242$ & $<.004$ & $<.01$ & $<.002$ & $<.04$ & $<.02$ & $<.01$ \\
\hline UY-06-57-824 & 08/20/01 & $<.02$ & $<.009$ & $<.02$ & $<.0242$ & $<.004$ & $<.01$ & $<.002$ & $<.04$ & $<.02$ & $<.01$ \\
\hline UY-10-07-631 & 08/20/01 & $<.02$ & $<.009$ & $<.02$ & $<.0242$ & $<.004$ & $<.01$ & $<.002$ & $<.04$ & $<.02$ & $<.01$ \\
\hline XT-11-44-605 & $08 / 25 / 01$ & $<.02$ & $<.009$ & $<.02$ & $<.0242$ & $<.004$ & $<.01$ & $<.002$ & $<.04$ & $<.02$ & $<.01$ \\
\hline$X Y-24-45-502$ & 08/07/01 & $<.02$ & $<.009$ & $<.02$ & $<.0242$ & $<.004$ & $<.01$ & $<.002$ & $<.04$ & $<.02$ & $<.01$ \\
\hline$X Y-24-47-207$ & 08/16/01 & $<.02$ & $<.009$ & $<.02$ & $<.0242$ & $<.004$ & $<.01$ & $<.002$ & $<.04$ & $<.02$ & $<.01$ \\
\hline$X Y-24-62-801$ & 08/08/01 & $<.02$ & $<.009$ & $<.02$ & $<.001$ & $<.004$ & $<.01$ & $<.002$ & $<.04$ & $<.02$ & $<.01$ \\
\hline ZT-24-43-202 & $08 / 12 / 01$ & $<.02$ & $<.009$ & $<.02$ & $<.0242$ & $<.004$ & $<.01$ & $<.002$ & $<.04$ & $<.02$ & $<.01$ \\
\hline ZT-24-50-602 & 08/11/01 & $<.02$ & $<.009$ & $<.02$ & $<.0008$ & $<.004$ & $<.01$ & $<.002$ & $<.04$ & $<.02$ & $<.01$ \\
\hline ZT-25-40-804 & 09/25/01 & $<.02$ & $<.009$ & $<.02$ & $<.0242$ & $<.004$ & $<.01$ & $<.002$ & $<.04$ & $<.02$ & $<.01$ \\
\hline
\end{tabular}


Appendix 6. Pesticide concentrations in water sampled from primarily domestic wells screened in the southern High Plains aquifer, Texas and New Mexico, 2001—Continued

\begin{tabular}{|c|c|c|c|c|c|c|c|c|c|c|c|}
\hline $\begin{array}{c}\text { State } \\
\text { well no. }\end{array}$ & $\begin{array}{c}\text { Alpha- } \\
\mathrm{HCH}\end{array}$ & $\begin{array}{c}\text { Aniline, } \\
2,6- \\
\text { diethyl- }\end{array}$ & Atrazine & $\begin{array}{l}\text { Atrazine, } \\
\text { deethyl- }\end{array}$ & $\begin{array}{c}\text { Atrazine, } \\
2- \\
\text { hydroxy- }\end{array}$ & $\begin{array}{c}\text { Atrazine, } \\
\text { deethyl- } \\
\text { deisopropl- }\end{array}$ & $\begin{array}{c}\text { Atrazine, } \\
\text { deiso- } \\
\text { propyl- }\end{array}$ & $\begin{array}{l}\text { Azinphos- } \\
\text { methyl }\end{array}$ & $\begin{array}{l}\text { Bendio- } \\
\text { carb }\end{array}$ & $\begin{array}{l}\text { Benflur- } \\
\text { alin }\end{array}$ & $\begin{array}{c}\text { Beno- } \\
\text { myl }\end{array}$ \\
\hline & Ipha-BHC & & & & & & & & & & \\
\hline NM03N.36E.28.411 & $<0.005$ & $<0.002$ & 0.115 & $<0.028$ & E0.012 & $<0.01$ & $<0.0021$ & $<0.05$ & $<0.025$ & $<0.01$ & $<0.004$ \\
\hline NM05N.34E.36.244 & $<.005$ & $<.002$ & $<.007$ & $<.006$ & $<.008$ & $<.01$ & $<.0006$ & $<.05$ & $<.025$ & $<.01$ & $<.004$ \\
\hline NM13S.38E.14.3333A & $<.005$ & $<.002$ & $<.007$ & $<.006$ & $<.008$ & $<.01$ & $<.04$ & $<.05$ & $<.025$ & $<.01$ & $<.004$ \\
\hline NM15S.38E.14.211 & $<.005$ & $<.002$ & $<.007$ & E.037 & $<.008$ & $<.01$ & E.06 & $<.05$ & $<.025$ & $<.01$ & $<.004$ \\
\hline NM01N.36E.21.233 & $<.005$ & $<.002$ & $<.009$ & $<.003$ & $<.008$ & $<.0004$ & $<.04$ & $<.05$ & $<.025$ & $<.01$ & $<.004$ \\
\hline NM02S.36E.17.231 & $<.005$ & $<.002$ & $<.007$ & $<.006$ & $<.008$ & $<.01$ & $<.04$ & $<.05$ & $<.025$ & $<.01$ & $<.004$ \\
\hline AB-27-29-905 & $<.005$ & $<.002$ & $<.007$ & $<.006$ & $<.008$ & $<.01$ & $<.04$ & $<.05$ & $<.025$ & $<.01$ & $<.004$ \\
\hline AR-25-08-603 & $<.005$ & $<.002$ & $<.009$ & $<.028$ & $<.008$ & $<.01$ & $<.04$ & $<.05$ & $<.025$ & $<.01$ & $<.004$ \\
\hline BL-11-38-925 & $<.005$ & $<.002$ & $<.007$ & $<.006$ & $<.008$ & $<.01$ & $<.04$ & $<.05$ & $<.025$ & $<.01$ & $<.004$ \\
\hline DD-10-30-803 & $<.005$ & $<.002$ & $<.009$ & $<.028$ & $<.008$ & $<.01$ & $<.04$ & $<.05$ & $<.025$ & $<.01$ & $<.004$ \\
\hline DP-24-19-405 & $<.005$ & $<.002$ & $<.007$ & $<.028$ & $<.008$ & $<.0002$ & $<.04$ & $<.05$ & $<.025$ & $<.01$ & $<.004$ \\
\hline DP-24-20-705 & $<.005$ & $<.002$ & $<.007$ & $<.028$ & $<.008$ & $<.01$ & $<.04$ & $<.05$ & $<.025$ & $<.01$ & $<.004$ \\
\hline HK-23-14-404 & $<.005$ & $<.002$ & $<.007$ & $<.006$ & $<.008$ & $<.01$ & $<.04$ & $<.05$ & $<.025$ & $<.01$ & $<.004$ \\
\hline HK-23-29-104 & $<.005$ & $<.002$ & $<.009$ & $<.028$ & $<.008$ & $<.01$ & $<.04$ & $<.05$ & $<.025$ & $<.01$ & $<.004$ \\
\hline HS-28-09-808 & $<.005$ & $<.002$ & $<.007$ & $<.006$ & $<.008$ & $<.01$ & $<.04$ & $<.05$ & $<.025$ & $<.01$ & $<.004$ \\
\hline HS-28-27-411 & $<.005$ & $<.002$ & $<.007$ & $<.006$ & $<.008$ & $<.01$ & $<.04$ & $<.05$ & $<.025$ & $<.01$ & $<.004$ \\
\hline HT-10-13-345 & $<.005$ & $<.002$ & $<.007$ & $<.006$ & $<.008$ & $<.01$ & $<.04$ & $<.05$ & $<.025$ & $<.01$ & $<.038$ \\
\hline HT-10-13-640 & $<.005$ & $<.002$ & $<.009$ & $<.002$ & $<.008$ & $<.0004$ & $<.04$ & $<.05$ & $<.025$ & $<.01$ & $<.004$ \\
\hline JW-23-08-101 & $<.005$ & $<.002$ & $<.007$ & $<.028$ & $<.008$ & $<.01$ & $<.04$ & $<.05$ & $<.025$ & $<.01$ & $<.004$ \\
\hline KD-26-24-203 & $<.005$ & $<.002$ & $<.007$ & $<.006$ & $<.008$ & $<.01$ & $<.04$ & $<.05$ & $<.025$ & $<.01$ & $<.004$ \\
\hline KD-27-01-807 & $<.005$ & $<.002$ & $<.007$ & $<.006$ & $<.008$ & $<.01$ & $<.04$ & $<.05$ & $<.025$ & $<.01$ & $<.004$ \\
\hline KD-27-19-518 & $<.005$ & $<.002$ & $<.007$ & $<.006$ & $<.008$ & $<.01$ & $<.04$ & $<.05$ & $<.025$ & $<.01$ & $<.004$ \\
\hline KD-27-30-103 & $<.005$ & $<.002$ & $<.007$ & $<.006$ & $<.008$ & $<.01$ & $<.04$ & $<.05$ & $<.025$ & $<.01$ & $<.004$ \\
\hline KY-11-43-805 & $<.005$ & $<.002$ & 0.078 & 0.078 & $<.008$ & $<.01$ & $<.04$ & $<.05$ & $<.025$ & $<.01$ & $<.004$ \\
\hline KY-11-49-207 & $<.005$ & $<.002$ & $<.009$ & $<.028$ & $<.008$ & $<.0015$ & $<.04$ & $<.05$ & $<.025$ & $<.01$ & $<.004$ \\
\hline KY-23-03-904 & $<.005$ & $<.002$ & $<.009$ & $<.028$ & $<.008$ & $<.01$ & $<.04$ & $<.05$ & $<.025$ & $<.01$ & $<.004$ \\
\hline KY-23-10-304 & $<.005$ & $<.002$ & $<.009$ & $<.028$ & $<.008$ & $<.01$ & $<.04$ & $<.05$ & $<.025$ & $<.01$ & $<.004$ \\
\hline PB-28-37-307 & $<.005$ & $<.002$ & $<.007$ & $<.028$ & $<.008$ & $<.01$ & $<.04$ & $<.05$ & $<.025$ & $<.01$ & $<.004$ \\
\hline RU-10-52-107 & $<.005$ & $<.002$ & $<.009$ & $<.028$ & $<.008$ & $<.01$ & $<.04$ & $<.05$ & $<.025$ & $<.01$ & $<.004$ \\
\hline RU-10-55-407 & $<.005$ & $<.002$ & $<.009$ & $<.028$ & $<.008$ & $<.01$ & $<.04$ & $<.05$ & $<.025$ & $<.01$ & $<.004$ \\
\hline SP-23-17-712 & $<.005$ & $<.002$ & $<.007$ & $<.006$ & $<.008$ & $<.01$ & $<.04$ & $<.05$ & $<.025$ & $<.01$ & $<.004$ \\
\hline SP-23-25-904 & $<.005$ & $<.002$ & 0.029 & E. 158 & $<.008$ & $<.01$ & $<.04$ & $<.05$ & $<.025$ & $<.01$ & $<.004$ \\
\hline SR-23-41-502 & $<.005$ & $<.002$ & $<.007$ & $<.006$ & $<.008$ & $<.01$ & $<.04$ & $<.05$ & $<.025$ & $<.01$ & $<.004$ \\
\hline SY-27-48-611 & $<.005$ & $<.002$ & $<.007$ & $<.006$ & $<.008$ & $<.01$ & $<.04$ & $<.05$ & $<.025$ & $<.01$ & $<.004$ \\
\hline SY-28-42-707 & $<.005$ & $<.002$ & $<.007$ & $<.006$ & $<.008$ & $<.01$ & $<.04$ & $<.05$ & $<.025$ & $<.01$ & $<.004$ \\
\hline SY-28-58-204 & $<.005$ & $<.002$ & $<.007$ & $<.006$ & $<.008$ & $<.01$ & $<.04$ & $<.05$ & $<.025$ & $<.01$ & $<.004$ \\
\hline UH-07-53-228 & $<.005$ & $<.002$ & $<.007$ & $<.006$ & $<.008$ & $<.01$ & $<.04$ & $<.05$ & $<.025$ & $<.01$ & $<.038$ \\
\hline UR-10-19-506 & $<.005$ & $<.002$ & $<.007$ & $<.006$ & $<.008$ & $<.01$ & $<.04$ & $<.05$ & $<.025$ & $<.01$ & $<.004$ \\
\hline UR-10-42-204 & $<.005$ & $<.002$ & 0.015 & $<.028$ & $<.001$ & $<.01$ & $<.04$ & $<.05$ & $<.025$ & $<.01$ & $<.004$ \\
\hline UY-06-57-824 & $<.005$ & $<.002$ & E.011 & E.234 & $<.008$ & E.02 & $<.04$ & $<.05$ & $<.025$ & $<.01$ & $<.004$ \\
\hline UY-10-07-631 & $<.005$ & $<.002$ & $<.007$ & $<.006$ & $<.008$ & $<.01$ & $<.04$ & $<.05$ & $<.025$ & $<.01$ & $<.038$ \\
\hline XT-11-44-605 & $<.005$ & $<.002$ & $<.007$ & $<.007$ & $<.008$ & $<.01$ & $<.04$ & $<.05$ & $<.025$ & $<.01$ & $<.004$ \\
\hline$X Y-24-45-502$ & $<.005$ & $<.002$ & $<.007$ & $<.006$ & $<.008$ & $<.01$ & $<.04$ & $<.05$ & $<.025$ & $<.01$ & $<.004$ \\
\hline XY-24-47-207 & $<.005$ & $<.002$ & $<.007$ & $<.028$ & $<.008$ & $<.01$ & $<.04$ & $<.05$ & $<.025$ & $<.01$ & $<.004$ \\
\hline XY-24-62-801 & $<.005$ & $<.002$ & $<.007$ & $<.006$ & $<.008$ & $<.01$ & $<.04$ & $<.05$ & $<.025$ & $<.01$ & $<.004$ \\
\hline ZT-24-43-202 & $<.005$ & $<.002$ & $<.007$ & $<.006$ & $<.008$ & $<.01$ & $<.04$ & $<.05$ & $<.025$ & $<.01$ & $<.004$ \\
\hline ZT-24-50-602 & $<.005$ & $<.002$ & $<.007$ & $<.006$ & $<.008$ & $<.01$ & $<.04$ & $<.05$ & $<.025$ & $<.01$ & $<.004$ \\
\hline ZT-25-40-804 & $<.005$ & $<.002$ & $<.007$ & $<.006$ & $<.008$ & $<.01$ & $<.04$ & $<.05$ & $<.025$ & $<.01$ & $<.004$ \\
\hline
\end{tabular}


Appendix 6. Pesticide concentrations in water sampled from primarily domestic wells screened in the southern High Plains aquifer, Texas and New Mexico, 2001-Continued

\begin{tabular}{|c|c|c|c|c|c|c|c|c|c|c|}
\hline $\begin{array}{c}\text { State } \\
\text { well no. }\end{array}$ & $\begin{array}{l}\text { Bensul- } \\
\text { furon- } \\
\text { methyl }\end{array}$ & $\begin{array}{l}\text { Benta- } \\
\text { zon }\end{array}$ & $\begin{array}{l}\text { Bro- } \\
\text { macil }\end{array}$ & $\begin{array}{c}\text { Bro- } \\
\text { moxynil }\end{array}$ & Butylate & $\begin{array}{l}\text { Car- } \\
\text { baryl }\end{array}$ & $\begin{array}{l}\text { Carbo- } \\
\text { furan }\end{array}$ & $\begin{array}{c}\text { Carbo- } \\
\text { furan, } \\
\text { 3-hydroxy- }\end{array}$ & $\begin{array}{l}\text { Carbo- } \\
\text { furan, } \\
\text { 3-keto- }\end{array}$ & $\begin{array}{c}\text { Chloramben } \\
\text { methyl } \\
\text { ester }\end{array}$ \\
\hline NM03N.36E.28.411 & $<0.0158$ & $<0.01$ & $<0.03$ & $<0.02$ & $<0.002$ & $<0.041$ & $<0.01$ & $<0.01$ & $<1.5$ & $<0.02$ \\
\hline NM05N.34E.36.244 & $<.0158$ & $<.01$ & $<.03$ & $<.02$ & $<.002$ & $<.041$ & $<.01$ & $<.01$ & $<1.5$ & $<.02$ \\
\hline NM13S.38E.14.3333A & $<.0158$ & $<.01$ & $<.03$ & $<.02$ & $<.002$ & $<.041$ & $<.01$ & $<.01$ & $<1.5$ & $<.02$ \\
\hline NM15S.38E.14.211 & $<.0158$ & $<.01$ & $<.03$ & $<.02$ & $<.002$ & $<.041$ & $<.01$ & $<.01$ & $<1.5$ & $<.02$ \\
\hline NM01N.36E.21.233 & $<.0158$ & $<.01$ & $<.03$ & $<.02$ & $<.002$ & $<.041$ & $<.01$ & $<.01$ & $<1.5$ & $<.02$ \\
\hline NM02S.36E.17.231 & $<.0158$ & $<.01$ & $<.03$ & $<.02$ & $<.002$ & $<.041$ & $<.01$ & $<.01$ & $<1.5$ & $<.02$ \\
\hline AB-27-29-905 & $<.0158$ & $<.01$ & $<.03$ & $<.02$ & $<.002$ & $<.041$ & $<.01$ & $<.01$ & $<1.5$ & $<.02$ \\
\hline AR-25-08-603 & $<.0158$ & $<.01$ & $<.03$ & $<.02$ & $<.002$ & $<.041$ & $<.01$ & $<.01$ & $<1.5$ & $<.02$ \\
\hline BL-11-38-925 & $<.0158$ & $<.01$ & $<.03$ & $<.02$ & $<.002$ & $<.041$ & $<.01$ & $<.01$ & $<1.5$ & $<.02$ \\
\hline DD-10-30-803 & $<.0158$ & $<.01$ & $<.03$ & $<.02$ & $<.002$ & $<.041$ & $<.01$ & $<.01$ & $<1.5$ & $<.02$ \\
\hline DP-24-19-405 & $<.0158$ & $<.01$ & $<.03$ & $<.02$ & $<.002$ & $<.041$ & $<.01$ & $<.01$ & $<1.5$ & $<.02$ \\
\hline DP-24-20-705 & $<.0158$ & $<.01$ & $<.03$ & $<.02$ & $<.002$ & $<.041$ & $<.01$ & $<.01$ & $<1.5$ & $<.02$ \\
\hline HK-23-14-404 & $<.0158$ & $<.01$ & $<.03$ & $<.02$ & $<.002$ & $<.041$ & $<.01$ & $<.01$ & $<1.5$ & $<.02$ \\
\hline HK-23-29-104 & $<.0158$ & $<.01$ & $<.03$ & $<.02$ & $<.002$ & $<.041$ & $<.01$ & $<.01$ & $<1.5$ & $<.02$ \\
\hline HS-28-09-808 & $<.0158$ & $<.01$ & $<.03$ & $<.02$ & $<.002$ & $<.041$ & $<.01$ & $<.01$ & $<1.5$ & $<.02$ \\
\hline HS-28-27-411 & $<.0158$ & $<.01$ & $<.03$ & $<.02$ & $<.002$ & $<.041$ & $<.01$ & $<.01$ & $<1.5$ & $<.02$ \\
\hline HT-10-13-345 & $<.0158$ & $<.01$ & $<.03$ & $<.02$ & $<.002$ & $<.041$ & $<.01$ & $<.01$ & $<1.5$ & $<.02$ \\
\hline HT-10-13-640 & $<.0158$ & $<.01$ & $<.03$ & $<.02$ & $<.002$ & $<.041$ & $<.01$ & $<.01$ & $<1.5$ & $<.02$ \\
\hline JW-23-08-101 & $<.0158$ & $<.01$ & $<.03$ & $<.02$ & $<.002$ & $<.041$ & $<.01$ & $<.01$ & $<1.5$ & $<.02$ \\
\hline KD-26-24-203 & $<.0158$ & $<.01$ & $<.03$ & $<.02$ & $<.002$ & $<.041$ & $<.01$ & $<.01$ & $<1.5$ & $<.02$ \\
\hline KD-27-01-807 & $<.0158$ & $<.01$ & $<.03$ & $<.02$ & $<.002$ & $<.041$ & $<.01$ & $<.01$ & $<1.5$ & $<.02$ \\
\hline KD-27-19-518 & $<.0158$ & $<.01$ & $<.03$ & $<.02$ & $<.002$ & $<.041$ & $<.01$ & $<.01$ & $<1.5$ & $<.02$ \\
\hline KD-27-30-103 & $<.0158$ & $<.01$ & $<.03$ & $<.02$ & $<.002$ & $<.041$ & $<.01$ & $<.01$ & $<1.5$ & $<.02$ \\
\hline KY-11-43-805 & $<.0158$ & $<.01$ & $<.03$ & $<.02$ & $<.002$ & $<.041$ & $<.01$ & $<.01$ & $<1.5$ & $<.02$ \\
\hline KY-11-49-207 & $<.0158$ & $<.01$ & $<.03$ & $<.02$ & $<.002$ & $<.041$ & $<.01$ & $<.01$ & $<1.5$ & $<.02$ \\
\hline KY-23-03-904 & $<.0158$ & $<.01$ & $<.03$ & $<.02$ & $<.002$ & $<.041$ & $<.01$ & $<.01$ & $<1.5$ & $<.02$ \\
\hline KY-23-10-304 & $<.0158$ & $<.01$ & $<.03$ & $<.02$ & $<.002$ & $<.041$ & $<.01$ & $<.01$ & $<1.5$ & $<.02$ \\
\hline PB-28-37-307 & $<.0158$ & $<.01$ & $<.03$ & $<.02$ & $<.002$ & $<.041$ & $<.01$ & $<.01$ & $<1.5$ & $<.02$ \\
\hline RU-10-52-107 & $<.0158$ & $<.01$ & $<.03$ & $<.02$ & $<.002$ & $<.041$ & $<.01$ & $<.01$ & $<1.5$ & $<.02$ \\
\hline RU-10-55-407 & $<.0158$ & $<.01$ & $<.03$ & $<.02$ & $<.002$ & $<.041$ & $<.01$ & $<.01$ & $<1.5$ & $<.02$ \\
\hline SP-23-17-712 & $<.0158$ & $<.01$ & $<.03$ & $<.02$ & $<.002$ & $<.041$ & $<.01$ & $<.01$ & $<1.5$ & $<.02$ \\
\hline SP-23-25-904 & $<.0158$ & $<.01$ & $<.03$ & $<.02$ & $<.002$ & $<.041$ & $<.01$ & $<.01$ & $<1.5$ & $<.02$ \\
\hline SR-23-41-502 & $<.0158$ & $<.01$ & $<.03$ & $<.02$ & $<.002$ & $<.041$ & $<.01$ & $<.01$ & $<1.5$ & $<.02$ \\
\hline SY-27-48-611 & $<.0158$ & $<.01$ & $<.03$ & $<.02$ & $<.002$ & $<.041$ & $<.01$ & $<.01$ & $<1.5$ & $<.02$ \\
\hline SY-28-42-707 & $<.0158$ & $<.01$ & $<.03$ & $<.02$ & $<.002$ & $<.041$ & $<.01$ & $<.01$ & $<1.5$ & $<.02$ \\
\hline SY-28-58-204 & $<.0158$ & $<.01$ & $<.03$ & $<.02$ & $<.002$ & $<.041$ & $<.01$ & $<.01$ & $<1.5$ & $<.02$ \\
\hline UH-07-53-228 & $<.0158$ & $<.01$ & $<.03$ & $<.02$ & $<.002$ & $<.041$ & $<.01$ & $<.01$ & $<1.5$ & $<.02$ \\
\hline UR-10-19-506 & $<.0158$ & $<.01$ & $<.03$ & $<.02$ & $<.002$ & $<.041$ & $<.01$ & $<.01$ & $<1.5$ & $<.02$ \\
\hline UR-10-42-204 & $<.0158$ & $<.01$ & $<.03$ & $<.02$ & $<.002$ & $<.041$ & $<.01$ & $<.01$ & $<1.5$ & $<.02$ \\
\hline UY-06-57-824 & $<.0158$ & $<.01$ & $<.03$ & $<.02$ & $<.002$ & $<.041$ & $<.01$ & $<.01$ & $<1.5$ & $<.02$ \\
\hline UY-10-07-631 & $<.0158$ & $<.01$ & $<.03$ & $<.02$ & $<.002$ & $<.041$ & $<.01$ & $<.01$ & $<1.5$ & $<.02$ \\
\hline XT-11-44-605 & $<.0158$ & $<.01$ & $<.03$ & $<.02$ & $<.002$ & $<.041$ & $<.01$ & $<.01$ & $<1.5$ & $<.02$ \\
\hline XY-24-45-502 & $<.0158$ & $<.01$ & $<.03$ & $<.02$ & $<.002$ & $<.041$ & $<.01$ & $<.01$ & $<1.5$ & $<.02$ \\
\hline XY-24-47-207 & $<.0158$ & $<.01$ & $<.03$ & $<.02$ & $<.002$ & $<.041$ & $<.01$ & $<.01$ & $<1.5$ & $<.02$ \\
\hline XY-24-62-801 & $<.0158$ & $<.01$ & $<.03$ & $<.02$ & $<.002$ & $<.041$ & $<.01$ & $<.01$ & $<1.5$ & $<.02$ \\
\hline ZT-24-43-202 & $<.0158$ & $<.01$ & $<.03$ & $<.02$ & $<.002$ & $<.041$ & $<.01$ & $<.01$ & $<1.5$ & $<.02$ \\
\hline ZT-24-50-602 & $<.0158$ & $<.01$ & $<.03$ & $<.02$ & $<.002$ & $<.041$ & $<.01$ & $<.01$ & $<1.5$ & $<.02$ \\
\hline ZT-25-40-804 & $<.0158$ & $<.01$ & $<.03$ & $<.02$ & $<.002$ & $<.041$ & $<.01$ & $<.01$ & $<1.5$ & $<.02$ \\
\hline
\end{tabular}


Appendix 6. Pesticide concentrations in water sampled from primarily domestic wells screened in the southern High Plains aquifer, Texas and New Mexico, 2001—Continued

\begin{tabular}{|c|c|c|c|c|c|c|c|c|c|c|c|}
\hline $\begin{array}{c}\text { State } \\
\text { well no. }\end{array}$ & $\begin{array}{c}\text { Chlori- } \\
\text { muron- } \\
\text { ethyl }\end{array}$ & $\begin{array}{l}\text { Chloro- } \\
\text { thalonil }\end{array}$ & $\begin{array}{l}\text { Chlor- } \\
\text { pyrifos }\end{array}$ & $\begin{array}{l}\text { Clopy- } \\
\text { ralid }\end{array}$ & $\begin{array}{l}\text { Cyana- } \\
\text { zine }\end{array}$ & Cycloate & DCPA & $\begin{array}{l}\text { Dacthal, } \\
\text { mono-acid }\end{array}$ & $\begin{array}{l}\text { Diazi- } \\
\text { non }\end{array}$ & $\begin{array}{l}\text { Dicam- } \\
\text { ba }\end{array}$ & $\begin{array}{c}\text { Dichlor- } \\
\text { prop }\end{array}$ \\
\hline & & & & & & & Dacthal & & & & \\
\hline NM03N.36E.28.411 & $<0.01$ & $<0.04$ & $<0.005$ & $<0.01$ & $<0.018$ & $<0.01$ & $<0.003$ & $<0.01$ & $<0.005$ & $<0.01$ & $<0.01$ \\
\hline NM05N.34E.36.244 & $<.01$ & $<.04$ & $<.005$ & $<.01$ & $<.018$ & $<.01$ & $<.003$ & $<.01$ & $<.005$ & $<.01$ & $<.01$ \\
\hline NM13S.38E.14.3333A & $<.01$ & $<.04$ & $<.005$ & $<.01$ & $<.018$ & $<.01$ & $<.003$ & $<.01$ & $<.005$ & $<.01$ & $<.01$ \\
\hline NM15S.38E.14.211 & $<.01$ & $<.04$ & $<.005$ & $<.01$ & $<.018$ & $<.01$ & $<.003$ & $<.01$ & $<.005$ & $<.01$ & $<.01$ \\
\hline NM01N.36E.21.233 & $<.01$ & $<.04$ & $<.005$ & $<.01$ & $<.018$ & $<.01$ & $<.003$ & $<.01$ & $<.005$ & $<.01$ & $<.01$ \\
\hline NM02S.36E.17.231 & $<.01$ & $<.04$ & $<.005$ & $<.01$ & $<.018$ & $<.01$ & $<.003$ & $<.01$ & $<.005$ & $<.01$ & $<.01$ \\
\hline AB-27-29-905 & $<.01$ & $<.04$ & $<.005$ & $<.01$ & $<.018$ & $<.01$ & $<.003$ & $<.01$ & $<.005$ & $<.01$ & $<.01$ \\
\hline AR-25-08-603 & $<.01$ & $<.04$ & $<.005$ & $<.01$ & $<.018$ & $<.01$ & $<.003$ & $<.01$ & $<.005$ & $<.01$ & $<.01$ \\
\hline BL-11-38-925 & $<.01$ & $<.04$ & $<.005$ & $<.01$ & $<.018$ & $<.01$ & $<.003$ & $<.01$ & $<.005$ & $<.01$ & $<.01$ \\
\hline DD-10-30-803 & $<.01$ & $<.04$ & $<.005$ & $<.01$ & $<.018$ & $<.01$ & $<.003$ & $<.01$ & $<.005$ & $<.01$ & $<.01$ \\
\hline DP-24-19-405 & $<.01$ & $<.04$ & $<.005$ & $<.01$ & $<.018$ & $<.01$ & $<.003$ & $<.01$ & $<.005$ & $<.01$ & $<.01$ \\
\hline DP-24-20-705 & $<.01$ & $<.04$ & $<.005$ & $<.01$ & $<.018$ & $<.01$ & $<.003$ & $<.01$ & $<.005$ & $<.01$ & $<.01$ \\
\hline HK-23-14-404 & $<.01$ & $<.04$ & $<.005$ & $<.01$ & $<.018$ & $<.01$ & $<.003$ & $<.01$ & $<.005$ & $<.01$ & $<.01$ \\
\hline HK-23-29-104 & $<.01$ & $<.04$ & $<.005$ & $<.01$ & $<.018$ & $<.01$ & $<.003$ & $<.01$ & $<.005$ & 0.02 & $<.01$ \\
\hline HS-28-09-808 & $<.01$ & $<.04$ & $<.005$ & $<.01$ & $<.018$ & $<.01$ & $<.003$ & $<.01$ & $<.005$ & $<.01$ & $<.01$ \\
\hline HS-28-27-411 & $<.01$ & $<.04$ & $<.005$ & $<.01$ & $<.018$ & $<.01$ & $<.003$ & $<.01$ & $<.005$ & $<.01$ & $<.01$ \\
\hline HT-10-13-345 & $<.01$ & $<.04$ & $<.005$ & $<.01$ & $<.018$ & $<.01$ & $<.003$ & $<.01$ & $<.005$ & $<.01$ & $<.01$ \\
\hline HT-10-13-640 & $<.01$ & $<.04$ & $<.005$ & $<.01$ & $<.018$ & $<.01$ & $<.003$ & $<.01$ & $<.005$ & $<.01$ & $<.01$ \\
\hline JW-23-08-101 & $<.01$ & $<.04$ & $<.005$ & $<.01$ & $<.018$ & $<.01$ & $<.003$ & $<.01$ & $<.005$ & $<.01$ & $<.01$ \\
\hline KD-26-24-203 & $<.01$ & $<.04$ & $<.005$ & $<.01$ & $<.018$ & $<.01$ & $<.003$ & $<.01$ & $<.005$ & $<.01$ & $<.01$ \\
\hline KD-27-01-807 & $<.01$ & $<.04$ & $<.005$ & $<.01$ & $<.018$ & $<.01$ & $<.003$ & $<.01$ & $<.005$ & $<.01$ & $<.01$ \\
\hline KD-27-19-518 & $<.01$ & $<.04$ & $<.005$ & $<.01$ & $<.018$ & $<.01$ & $<.003$ & $<.01$ & $<.005$ & $<.01$ & $<.01$ \\
\hline KD-27-30-103 & $<.01$ & $<.04$ & $<.005$ & $<.01$ & $<.018$ & $<.01$ & $<.003$ & $<.01$ & $<.005$ & $<.01$ & $<.01$ \\
\hline KY-11-43-805 & $<.01$ & $<.04$ & $<.005$ & $<.01$ & $<.018$ & $<.01$ & $<.003$ & $<.01$ & $<.005$ & $<.01$ & $<.01$ \\
\hline KY-11-49-207 & $<.01$ & $<.04$ & $<.005$ & $<.01$ & $<.018$ & $<.01$ & $<.003$ & $<.01$ & $<.005$ & $<.01$ & $<.01$ \\
\hline KY-23-03-904 & $<.01$ & $<.04$ & $<.005$ & $<.01$ & $<.018$ & $<.01$ & $<.003$ & $<.01$ & $<.005$ & $<.01$ & $<.01$ \\
\hline KY-23-10-304 & $<.01$ & $<.04$ & $<.005$ & $<.01$ & $<.018$ & $<.01$ & $<.003$ & $<.01$ & $<.005$ & $<.01$ & $<.01$ \\
\hline PB-28-37-307 & $<.01$ & $<.04$ & $<.005$ & $<.01$ & $<.018$ & $<.01$ & $<.003$ & $<.01$ & $<.005$ & $<.01$ & $<.01$ \\
\hline RU-10-52-107 & $<.01$ & $<.04$ & $<.005$ & $<.01$ & $<.018$ & $<.01$ & $<.003$ & $<.01$ & $<.005$ & $<.01$ & $<.01$ \\
\hline RU-10-55-407 & $<.01$ & $<.04$ & $<.005$ & $<.01$ & $<.018$ & $<.01$ & $<.003$ & $<.01$ & $<.005$ & $<.01$ & $<.01$ \\
\hline SP-23-17-712 & $<.01$ & $<.04$ & $<.005$ & $<.01$ & $<.018$ & $<.01$ & $<.003$ & $<.01$ & $<.005$ & $<.01$ & $<.01$ \\
\hline SP-23-25-904 & $<.01$ & $<.04$ & $<.005$ & $<.01$ & $<.018$ & $<.01$ & $<.003$ & 0.04 & $<.005$ & $<.01$ & $<.01$ \\
\hline SR-23-41-502 & $<.01$ & $<.04$ & $<.005$ & $<.01$ & $<.018$ & $<.01$ & $<.003$ & $<.01$ & $<.005$ & $<.01$ & $<.01$ \\
\hline SY-27-48-611 & $<.01$ & $<.04$ & $<.005$ & $<.01$ & $<.018$ & $<.01$ & $<.003$ & $<.01$ & $<.005$ & $<.01$ & $<.01$ \\
\hline SY-28-42-707 & $<.01$ & $<.04$ & $<.005$ & $<.01$ & $<.018$ & $<.01$ & $<.003$ & $<.01$ & $<.005$ & $<.01$ & $<.01$ \\
\hline SY-28-58-204 & $<.01$ & $<.04$ & $<.005$ & $<.01$ & $<.018$ & $<.01$ & $<.003$ & $<.01$ & $<.005$ & $<.01$ & $<.01$ \\
\hline $\mathrm{UH}-07-53-228$ & $<.01$ & $<.04$ & $<.005$ & $<.01$ & $<.018$ & $<.01$ & $<.003$ & $<.01$ & $<.005$ & $<.01$ & $<.01$ \\
\hline UR-10-19-506 & $<.01$ & $<.04$ & $<.005$ & $<.01$ & $<.018$ & $<.01$ & $<.003$ & $<.01$ & $<.005$ & $<.01$ & $<.01$ \\
\hline UR-10-42-204 & $<.01$ & $<.04$ & $<.005$ & $<.01$ & $<.018$ & $<.01$ & $<.003$ & $<.01$ & $<.005$ & $<.01$ & $<.01$ \\
\hline UY-06-57-824 & $<.01$ & $<.04$ & $<.005$ & $<.01$ & $<.018$ & $<.01$ & $<.003$ & $<.01$ & $<.005$ & $<.01$ & $<.01$ \\
\hline UY-10-07-631 & $<.01$ & $<.04$ & $<.005$ & $<.01$ & $<.018$ & $<.01$ & $<.003$ & $<.01$ & $<.005$ & $<.01$ & $<.01$ \\
\hline XT-11-44-605 & $<.01$ & $<.04$ & $<.005$ & $<.01$ & $<.018$ & $<.01$ & $<.003$ & $<.01$ & $<.005$ & $<.01$ & $<.01$ \\
\hline$X Y-24-45-502$ & $<.01$ & $<.04$ & $<.005$ & $<.01$ & $<.018$ & $<.01$ & $<.003$ & $<.01$ & $<.005$ & $<.01$ & $<.01$ \\
\hline$X Y-24-47-207$ & $<.01$ & $<.04$ & $<.005$ & $<.01$ & $<.018$ & $<.01$ & $<.003$ & $<.01$ & $<.005$ & $<.01$ & $<.01$ \\
\hline$X Y-24-62-801$ & $<.01$ & $<.04$ & $<.005$ & $<.01$ & $<.018$ & $<.01$ & $<.003$ & $<.01$ & $<.005$ & $<.01$ & $<.01$ \\
\hline ZT-24-43-202 & $<.01$ & $<.04$ & $<.005$ & $<.01$ & $<.018$ & $<.01$ & $<.003$ & $<.01$ & $<.005$ & $<.01$ & $<.01$ \\
\hline ZT-24-50-602 & $<.01$ & $<.04$ & $<.005$ & $<.01$ & $<.018$ & $<.01$ & $<.003$ & $<.01$ & $<.005$ & $<.01$ & $<.01$ \\
\hline ZT-25-40-804 & $<.01$ & $<.04$ & $<.005$ & $<.01$ & $<.018$ & $<.01$ & $<.003$ & $<.01$ & $<.005$ & $<.01$ & $<.01$ \\
\hline
\end{tabular}


Appendix 6. Pesticide concentrations in water sampled from primarily domestic wells screened in the southern aquifer, Texas and New Mexico, 2001-Continued

\begin{tabular}{|c|c|c|c|c|c|c|c|c|c|c|c|}
\hline $\begin{array}{c}\text { State } \\
\text { well no. }\end{array}$ & $\begin{array}{l}\text { Dield- } \\
\text { rin }\end{array}$ & $\begin{array}{l}\text { Dino- } \\
\text { seb }\end{array}$ & $\begin{array}{l}\text { Diphen- } \\
\text { amid }\end{array}$ & $\begin{array}{l}\text { Disulf- } \\
\text { oton }\end{array}$ & Diuron & EPTC & $\begin{array}{l}\text { Ethal- } \\
\text { fluralin }\end{array}$ & $\begin{array}{c}\text { Etho- } \\
\text { prophos }\end{array}$ & Fenuron & $\begin{array}{l}\text { Flumet- } \\
\text { sulam }\end{array}$ & $\begin{array}{c}\text { Fluome- } \\
\text { turon }\end{array}$ \\
\hline NM03N.36E.28.411 & $<0.005$ & $<0.0003$ & $<0.03$ & $<0.021$ & $<0.01$ & $<0.002$ & $<0.009$ & $<0.005$ & $<0.0003$ & $<0.011$ & $<0.03$ \\
\hline NM05N.34E.36.244 & $<.005$ & $<.01$ & $<.03$ & $<.021$ & $<.01$ & $<.002$ & $<.009$ & $<.005$ & $<.03$ & $<.011$ & $<.03$ \\
\hline NM13S.38E.14.3333A & $<.005$ & $<.01$ & $<.03$ & $<.021$ & $<.01$ & $<.002$ & $<.009$ & $<.005$ & $<.03$ & $<.011$ & $<.03$ \\
\hline NM15S.38E.14.211 & $<.005$ & $<.01$ & $<.03$ & $<.021$ & $<.0012$ & $<.002$ & $<.009$ & $<.005$ & $<.0028$ & $<.011$ & $<.03$ \\
\hline NM01N.36E.21.233 & $<.005$ & $<.01$ & $<.03$ & $<.021$ & $<.01$ & $<.002$ & $<.009$ & $<.005$ & $<.03$ & $<.011$ & $<.03$ \\
\hline NM02S.36E.17.231 & $<.005$ & $<.0004$ & $<.03$ & $<.021$ & $<.01$ & $<.002$ & $<.009$ & $<.005$ & $<.0003$ & $<.011$ & $<.03$ \\
\hline AB-27-29-905 & $<.005$ & $<.01$ & $<.03$ & $<.021$ & $<.0013$ & $<.002$ & $<.009$ & $<.005$ & $<.0009$ & $<.011$ & $<.0004$ \\
\hline AR-25-08-603 & $<.005$ & $<.01$ & $<.03$ & $<.021$ & $<.01$ & $<.002$ & $<.009$ & $<.005$ & $<.03$ & $<.011$ & $<.03$ \\
\hline BL-11-38-925 & $<.005$ & $<.01$ & $<.03$ & $<.021$ & $<.01$ & $<.002$ & $<.009$ & $<.005$ & $<.03$ & $<.011$ & $<.03$ \\
\hline DD-10-30-803 & $<.005$ & $<.01$ & $<.03$ & $<.021$ & $<.01$ & $<.002$ & $<.009$ & $<.005$ & $<.03$ & $<.011$ & $<.03$ \\
\hline DP-24-19-405 & $<.005$ & $<.01$ & $<.03$ & $<.021$ & $<.01$ & $<.002$ & $<.009$ & $<.005$ & $<.03$ & $<.011$ & $<.03$ \\
\hline DP-24-20-705 & $<.005$ & $<.01$ & $<.03$ & $<.021$ & $<.01$ & $<.002$ & $<.009$ & $<.005$ & $<.03$ & $<.011$ & $<.03$ \\
\hline HK-23-14-404 & $<.005$ & $<.01$ & $<.03$ & $<.021$ & $<.01$ & $<.002$ & $<.009$ & $<.005$ & $<.03$ & $<.011$ & $<.03$ \\
\hline HK-23-29-104 & $<.005$ & $<.01$ & $<.03$ & $<.021$ & $<.01$ & $<.002$ & $<.009$ & $<.005$ & $<.0002$ & $<.011$ & $<.03$ \\
\hline HS-28-09-808 & $<.005$ & $<.01$ & $<.03$ & $<.021$ & $<.0011$ & $<.002$ & $<.009$ & $<.005$ & $<.0007$ & $<.011$ & $<.03$ \\
\hline HS-28-27-411 & $<.005$ & $<.01$ & $<.03$ & $<.021$ & $<.0013$ & $<.002$ & $<.009$ & $<.005$ & $<.0007$ & $<.011$ & $<.03$ \\
\hline HT-10-13-345 & $<.005$ & $<.01$ & $<.03$ & $<.021$ & $<.01$ & $<.002$ & $<.009$ & $<.005$ & $<.03$ & $<.011$ & $<.03$ \\
\hline HT-10-13-640 & $<.005$ & $<.01$ & $<.03$ & $<.021$ & $<.01$ & $<.002$ & $<.009$ & $<.005$ & $<.03$ & $<.011$ & $<.03$ \\
\hline JW-23-08-101 & $<.005$ & $<.01$ & $<.03$ & $<.021$ & $<.01$ & $<.002$ & $<.009$ & $<.005$ & $<.03$ & $<.011$ & $<.03$ \\
\hline KD-26-24-203 & $<.005$ & $<.01$ & $<.03$ & $<.021$ & $<.01$ & $<.002$ & $<.009$ & $<.005$ & $<.03$ & $<.011$ & $<.0017$ \\
\hline KD-27-01-807 & $<.005$ & $<.01$ & $<.03$ & $<.021$ & $<.0012$ & $<.002$ & $<.009$ & $<.005$ & $<.03$ & $<.011$ & $<.03$ \\
\hline KD-27-19-518 & $<.005$ & $<.01$ & $<.03$ & $<.021$ & $<.001$ & $<.002$ & $<.009$ & $<.005$ & $<.0016$ & $<.011$ & $<.03$ \\
\hline KD-27-30-103 & $<.005$ & $<.01$ & $<.03$ & $<.021$ & $<.01$ & $<.002$ & $<.009$ & $<.005$ & $<.0007$ & $<.011$ & $<.03$ \\
\hline KY-11-43-805 & $<.005$ & $<.0004$ & $<.03$ & $<.021$ & $<.01$ & $<.002$ & $<.009$ & $<.005$ & $<.03$ & $<.011$ & $<.03$ \\
\hline KY-11-49-207 & $<.005$ & $<.01$ & $<.03$ & $<.021$ & $<.01$ & $<.002$ & $<.009$ & $<.005$ & $<.03$ & $<.011$ & $<.03$ \\
\hline KY-23-03-904 & $<.005$ & $<.01$ & $<.03$ & $<.021$ & $<.01$ & $<.002$ & $<.009$ & $<.005$ & $<.03$ & $<.011$ & $<.03$ \\
\hline KY-23-10-304 & $<.005$ & $<.01$ & $<.03$ & $<.021$ & $<.01$ & $<.002$ & $<.009$ & $<.005$ & $<.03$ & $<.011$ & $<.03$ \\
\hline PB-28-37-307 & $<.005$ & $<.01$ & $<.03$ & $<.021$ & $<.01$ & $<.002$ & $<.009$ & $<.005$ & $<.03$ & $<.011$ & $<.03$ \\
\hline RU-10-52-107 & $<.005$ & $<.01$ & $<.03$ & $<.021$ & $<.01$ & $<.002$ & $<.009$ & $<.005$ & $<.03$ & $<.011$ & $<.03$ \\
\hline RU-10-55-407 & $<.005$ & $<.01$ & $<.03$ & $<.021$ & $<.01$ & $<.002$ & $<.009$ & $<.005$ & $<.03$ & $<.011$ & $<.03$ \\
\hline SP-23-17-712 & $<.005$ & $<.01$ & $<.03$ & $<.021$ & $<.0012$ & $<.002$ & $<.009$ & $<.005$ & $<.03$ & $<.011$ & $<.03$ \\
\hline SP-23-25-904 & $<.005$ & $<.01$ & $<.03$ & $<.021$ & $<.01$ & $<.002$ & $<.009$ & $<.005$ & $<.03$ & $<.011$ & $<.03$ \\
\hline SR-23-41-502 & $<.005$ & $<.01$ & $<.03$ & $<.021$ & $<.01$ & $<.002$ & $<.009$ & $<.005$ & $<.03$ & $<.011$ & $<.03$ \\
\hline SY-27-48-611 & $<.005$ & $<.01$ & $<.03$ & $<.021$ & $<.0011$ & $<.002$ & $<.009$ & $<.005$ & $<.0007$ & $<.011$ & $<.03$ \\
\hline SY-28-42-707 & $<.005$ & $<.01$ & $<.03$ & $<.021$ & $<.0014$ & $<.002$ & $<.009$ & $<.005$ & $<.0018$ & $<.011$ & $<.03$ \\
\hline SY-28-58-204 & $<.005$ & $<.01$ & $<.03$ & $<.021$ & $<.01$ & $<.002$ & $<.009$ & $<.005$ & $<.0006$ & $<.011$ & $<.03$ \\
\hline UH-07-53-228 & $<.005$ & $<.01$ & $<.03$ & $<.021$ & $<.01$ & $<.002$ & $<.009$ & $<.005$ & $<.03$ & $<.011$ & $<.03$ \\
\hline UR-10-19-506 & $<.005$ & $<.01$ & $<.03$ & $<.021$ & $<.01$ & $<.002$ & $<.009$ & $<.005$ & $<.03$ & $<.011$ & $<.03$ \\
\hline UR-10-42-204 & $<.005$ & $<.01$ & $<.03$ & $<.021$ & $<.01$ & $<.002$ & $<.009$ & $<.005$ & $<.03$ & $<.011$ & $<.03$ \\
\hline UY-06-57-824 & $<.005$ & $<.01$ & $<.03$ & $<.021$ & $<.01$ & $<.002$ & $<.009$ & $<.005$ & $<.03$ & $<.011$ & $<.03$ \\
\hline UY-10-07-631 & $<.005$ & $<.01$ & $<.03$ & $<.021$ & $<.01$ & $<.002$ & $<.009$ & $<.005$ & $<.03$ & $<.011$ & $<.03$ \\
\hline XT-11-44-605 & $<.005$ & $<.01$ & $<.03$ & $<.021$ & $<.01$ & $<.002$ & $<.009$ & $<.005$ & $<.0003$ & $<.011$ & $<.03$ \\
\hline$X Y-24-45-502$ & $<.005$ & $<.0005$ & $<.03$ & $<.021$ & $<.01$ & $<.002$ & $<.009$ & $<.005$ & $<.0007$ & $<.011$ & $<.03$ \\
\hline$X Y-24-47-207$ & $<.005$ & $<.01$ & $<.03$ & $<.021$ & $<.0015$ & $<.002$ & $<.009$ & $<.005$ & $<.0013$ & $<.011$ & $<.03$ \\
\hline XY-24-62-801 & $<.005$ & $<.01$ & $<.03$ & $<.021$ & $<.001$ & $<.002$ & $<.009$ & $<.005$ & $<.03$ & $<.011$ & $<.03$ \\
\hline ZT-24-43-202 & $<.005$ & $<.01$ & $<.03$ & $<.021$ & $<.01$ & $<.002$ & $<.009$ & $<.005$ & $<.03$ & $<.011$ & $<.0013$ \\
\hline ZT-24-50-602 & $<.005$ & $<.01$ & $<.03$ & $<.021$ & $<.0012$ & $<.002$ & $<.009$ & $<.005$ & $<.03$ & $<.011$ & $<.03$ \\
\hline ZT-25-40-804 & $<.005$ & $<.01$ & $<.03$ & $<.021$ & $<.01$ & $<.002$ & $<.009$ & $<.005$ & $<.03$ & $<.011$ & $<.03$ \\
\hline
\end{tabular}


Appendix 6. Pesticide concentrations in water sampled from primarily domestic wells screened in the southern High Plains aquifer, Texas and New Mexico, 2001—Continued

\begin{tabular}{|c|c|c|c|c|c|c|c|c|c|c|c|c|}
\hline $\begin{array}{c}\text { State } \\
\text { well no. }\end{array}$ & Fonofos & $\begin{array}{l}\text { Imaza- } \\
\text { quin }\end{array}$ & $\begin{array}{l}\text { Imaz- } \\
\text { ethapyr }\end{array}$ & $\begin{array}{l}\text { Imida- } \\
\text { cloprid }\end{array}$ & $\begin{array}{l}\text { Lin- } \\
\text { dane }\end{array}$ & $\begin{array}{l}\text { Linu- } \\
\text { ron }\end{array}$ & $\begin{array}{l}\text { Mala- } \\
\text { thion }\end{array}$ & MCPA & MCPB & $\begin{array}{l}\text { Meta- } \\
\text { laxyl }\end{array}$ & $\begin{array}{l}\text { Methio- } \\
\text { carb }\end{array}$ & $\begin{array}{c}\text { Metho- } \\
\text { myl }\end{array}$ \\
\hline \multicolumn{13}{|c|}{$\begin{array}{c}\text { gamma- } \\
\mathrm{HCH}\end{array}$} \\
\hline NM03N.36E.28.411 & $<0.003$ & $<0.016$ & $<0.017$ & $<0.0068$ & $<0.004$ & $<0.01$ & $<0.027$ & $<0.02$ & $<0.01$ & $<0.02$ & $<0.01$ & $<0.0044$ \\
\hline NM05N.34E.36.244 & $<.003$ & $<.016$ & $<.017$ & $<.0068$ & $<.004$ & $<.01$ & $<.027$ & $<.02$ & $<.01$ & $<.02$ & $<.01$ & $<.0044$ \\
\hline NM13S.38E.14.3333A & $<.003$ & $<.016$ & $<.017$ & $<.0068$ & $<.004$ & $<.01$ & $<.027$ & $<.02$ & $<.01$ & $<.02$ & $<.01$ & $<.0044$ \\
\hline NM15S.38E.14.211 & $<.003$ & $<.016$ & $<.017$ & $<.0068$ & $<.004$ & $<.01$ & $<.027$ & $<.02$ & $<.01$ & $<.02$ & $<.01$ & $<.0044$ \\
\hline NM01N.36E.21.233 & $<.003$ & $<.016$ & $<.017$ & $<.0068$ & $<.004$ & $<.01$ & $<.027$ & $<.02$ & $<.01$ & $<.02$ & $<.01$ & $<.0044$ \\
\hline NM02S.36E.17.231 & $<.003$ & $<.016$ & $<.017$ & $<.0068$ & $<.004$ & $<.01$ & $<.027$ & $<.02$ & $<.01$ & $<.02$ & $<.01$ & $<.0044$ \\
\hline AB-27-29-905 & $<.003$ & $<.016$ & $<.017$ & $<.0068$ & $<.004$ & $<.01$ & $<.027$ & $<.02$ & $<.01$ & $<.02$ & $<.01$ & $<.0044$ \\
\hline AR-25-08-603 & $<.003$ & $<.016$ & $<.017$ & $<.0068$ & $<.004$ & $<.01$ & $<.027$ & $<.02$ & $<.01$ & $<.02$ & $<.01$ & $<.0044$ \\
\hline BL-11-38-925 & $<.003$ & $<.016$ & $<.017$ & $<.0068$ & $<.004$ & $<.01$ & $<.027$ & $<.02$ & $<.01$ & $<.02$ & $<.01$ & $<.0044$ \\
\hline DD-10-30-803 & $<.003$ & $<.016$ & $<.017$ & $<.0068$ & $<.004$ & $<.01$ & $<.027$ & $<.02$ & $<.01$ & $<.02$ & $<.01$ & $<.0044$ \\
\hline DP-24-19-405 & $<.003$ & $<.016$ & $<.017$ & $<.0068$ & $<.004$ & $<.01$ & $<.027$ & $<.02$ & $<.01$ & $<.02$ & $<.01$ & $<.0044$ \\
\hline DP-24-20-705 & $<.003$ & $<.016$ & $<.017$ & $<.0068$ & $<.004$ & $<.01$ & $<.027$ & $<.02$ & $<.01$ & $<.02$ & $<.01$ & $<.0044$ \\
\hline HK-23-14-404 & $<.003$ & $<.016$ & $<.017$ & $<.0068$ & $<.004$ & $<.01$ & $<.027$ & $<.02$ & $<.01$ & $<.02$ & $<.01$ & $<.0044$ \\
\hline HK-23-29-104 & $<.003$ & $<.016$ & $<.017$ & $<.0068$ & $<.004$ & $<.01$ & $<.027$ & $<.02$ & $<.01$ & $<.02$ & $<.01$ & $<.0044$ \\
\hline HS-28-09-808 & $<.003$ & $<.001$ & $<.017$ & $<.0068$ & $<.004$ & $<.01$ & $<.027$ & $<.02$ & $<.01$ & $<.02$ & $<.01$ & $<.0044$ \\
\hline HS-28-27-411 & $<.003$ & $<.016$ & $<.017$ & $<.0068$ & $<.004$ & $<.01$ & $<.027$ & $<.02$ & $<.01$ & $<.02$ & $<.01$ & $<.0044$ \\
\hline HT-10-13-345 & $<.003$ & $<.016$ & $<.017$ & $<.1105$ & $<.004$ & $<.01$ & $<.027$ & $<.02$ & $<.01$ & $<.02$ & $<.01$ & $<.0044$ \\
\hline HT-10-13-640 & $<.003$ & $<.016$ & $<.017$ & $<.0068$ & $<.004$ & $<.01$ & $<.027$ & $<.02$ & $<.01$ & $<.02$ & $<.01$ & $<.0044$ \\
\hline JW-23-08-101 & $<.003$ & $<.016$ & $<.017$ & $<.0068$ & $<.004$ & $<.01$ & $<.027$ & $<.02$ & $<.01$ & $<.02$ & $<.01$ & $<.0044$ \\
\hline KD-26-24-203 & $<.003$ & $<.016$ & $<.017$ & $<.0068$ & $<.004$ & $<.01$ & $<.027$ & $<.02$ & $<.01$ & $<.02$ & $<.01$ & $<.0044$ \\
\hline KD-27-01-807 & $<.003$ & $<.016$ & $<.017$ & $<.0068$ & $<.004$ & $<.01$ & $<.027$ & $<.02$ & $<.01$ & $<.02$ & $<.01$ & $<.0044$ \\
\hline KD-27-19-518 & $<.003$ & $<.016$ & $<.001$ & $<.0068$ & $<.004$ & $<.01$ & $<.027$ & $<.02$ & $<.01$ & $<.02$ & $<.01$ & $<.0044$ \\
\hline KD-27-30-103 & $<.003$ & $<.002$ & $<.017$ & $<.0068$ & $<.004$ & $<.01$ & $<.027$ & $<.02$ & $<.01$ & $<.02$ & $<.01$ & $<.0044$ \\
\hline KY-11-43-805 & $<.003$ & $<.002$ & $<.017$ & $<.0068$ & $<.004$ & $<.01$ & $<.027$ & $<.02$ & $<.01$ & $<.02$ & $<.01$ & $<.0044$ \\
\hline KY-11-49-207 & $<.003$ & $<.016$ & $<.017$ & $<.0068$ & $<.004$ & $<.01$ & $<.027$ & $<.02$ & $<.01$ & $<.02$ & $<.01$ & $<.0044$ \\
\hline KY-23-03-904 & $<.003$ & $<.016$ & $<.017$ & $<.0068$ & $<.004$ & $<.01$ & $<.027$ & $<.02$ & $<.01$ & $<.02$ & $<.01$ & $<.0044$ \\
\hline KY-23-10-304 & $<.003$ & $<.016$ & $<.017$ & $<.0068$ & $<.004$ & $<.01$ & 0.029 & $<.02$ & $<.01$ & $<.02$ & $<.01$ & $<.0044$ \\
\hline PB-28-37-307 & $<.003$ & $<.016$ & $<.017$ & $<.0068$ & $<.004$ & $<.01$ & $<.027$ & $<.02$ & $<.01$ & $<.02$ & $<.01$ & $<.0044$ \\
\hline RU-10-52-107 & $<.003$ & $<.016$ & $<.017$ & $<.0068$ & $<.004$ & $<.01$ & $<.027$ & $<.02$ & $<.01$ & $<.02$ & $<.01$ & $<.0044$ \\
\hline RU-10-55-407 & $<.003$ & $<.016$ & $<.017$ & $<.0068$ & $<.004$ & $<.01$ & $<.027$ & $<.02$ & $<.01$ & $<.02$ & $<.01$ & $<.0044$ \\
\hline SP-23-17-712 & $<.003$ & $<.016$ & $<.017$ & $<.0068$ & $<.004$ & $<.01$ & $<.027$ & $<.02$ & $<.01$ & $<.02$ & $<.01$ & $<.0044$ \\
\hline SP-23-25-904 & $<.003$ & $<.016$ & $<.017$ & $<.0068$ & $<.004$ & $<.01$ & $<.027$ & $<.02$ & $<.01$ & $<.02$ & $<.01$ & $<.0044$ \\
\hline SR-23-41-502 & $<.003$ & $<.016$ & $<.017$ & $<.0068$ & $<.004$ & $<.01$ & $<.027$ & $<.02$ & $<.01$ & $<.02$ & $<.01$ & $<.0044$ \\
\hline SY-27-48-611 & $<.003$ & $<.016$ & $<.017$ & $<.0068$ & $<.004$ & $<.01$ & $<.027$ & $<.02$ & $<.01$ & $<.02$ & $<.01$ & $<.0044$ \\
\hline SY-28-42-707 & $<.003$ & $<.016$ & $<.017$ & $<.0068$ & $<.004$ & $<.01$ & $<.027$ & $<.02$ & $<.01$ & $<.02$ & $<.01$ & $<.0044$ \\
\hline SY-28-58-204 & $<.003$ & $<.016$ & $<.017$ & $<.0068$ & $<.004$ & $<.01$ & $<.027$ & $<.02$ & $<.01$ & $<.02$ & $<.01$ & $<.0044$ \\
\hline $\mathrm{UH}-07-53-228$ & $<.003$ & $<.016$ & $<.017$ & $<.1105$ & $<.004$ & $<.01$ & $<.027$ & $<.02$ & $<.01$ & $<.02$ & $<.01$ & $<.0044$ \\
\hline UR-10-19-506 & $<.003$ & $<.016$ & $<.017$ & $<.0068$ & $<.004$ & $<.01$ & $<.027$ & $<.02$ & $<.01$ & $<.02$ & $<.01$ & $<.0044$ \\
\hline UR-10-42-204 & $<.003$ & $<.016$ & $<.017$ & $<.0068$ & $<.004$ & $<.01$ & $<.027$ & $<.02$ & $<.01$ & $<.02$ & $<.01$ & $<.0044$ \\
\hline UY-06-57-824 & $<.003$ & $<.016$ & $<.017$ & $<.1105$ & $<.004$ & $<.01$ & $<.027$ & $<.02$ & $<.01$ & $<.02$ & $<.01$ & $<.0044$ \\
\hline UY-10-07-631 & $<.003$ & $<.016$ & $<.017$ & $<.1105$ & $<.004$ & $<.01$ & $<.027$ & $<.02$ & $<.01$ & $<.02$ & $<.01$ & $<.0044$ \\
\hline XT-11-44-605 & $<.003$ & $<.016$ & $<.017$ & $<.0068$ & $<.004$ & $<.01$ & $<.027$ & $<.02$ & $<.01$ & $<.02$ & $<.01$ & $<.0044$ \\
\hline$X Y-24-45-502$ & $<.003$ & $<.002$ & $<.017$ & $<.0068$ & $<.004$ & $<.01$ & $<.027$ & $<.02$ & $<.01$ & $<.02$ & $<.01$ & $<.0044$ \\
\hline$X Y-24-47-207$ & $<.003$ & $<.016$ & $<.017$ & $<.0068$ & $<.004$ & $<.01$ & $<.027$ & $<.02$ & $<.01$ & $<.02$ & $<.01$ & $<.0009$ \\
\hline$X Y-24-62-801$ & $<.003$ & $<.016$ & $<.017$ & $<.0068$ & $<.004$ & $<.01$ & $<.027$ & $<.02$ & $<.01$ & $<.02$ & $<.01$ & $<.0044$ \\
\hline ZT-24-43-202 & $<.003$ & $<.016$ & $<.017$ & $<.0068$ & $<.004$ & $<.01$ & $<.027$ & $<.02$ & $<.01$ & $<.02$ & $<.01$ & $<.0044$ \\
\hline ZT-24-50-602 & $<.003$ & $<.016$ & $<.017$ & $<.0068$ & $<.004$ & $<.01$ & $<.027$ & $<.02$ & $<.01$ & $<.02$ & $<.01$ & $<.0044$ \\
\hline ZT-25-40-804 & $<.003$ & $<.016$ & $<.017$ & $<.0068$ & $<.004$ & $<.01$ & $<.027$ & $<.02$ & $<.01$ & $<.02$ & $<.01$ & $<.0044$ \\
\hline
\end{tabular}


Appendix 6. Pesticide concentrations in water sampled from primarily domestic wells screened in the southern High Plains aquifer, Texas and New Mexico, 2001—Continued

\begin{tabular}{|c|c|c|c|c|c|c|c|c|c|c|}
\hline $\begin{array}{c}\text { State } \\
\text { well no. }\end{array}$ & $\begin{array}{c}\text { Methyl } \\
\text { oxime }\end{array}$ & $\begin{array}{l}\text { Meto- } \\
\text { lachlor }\end{array}$ & $\begin{array}{l}\text { Metri- } \\
\text { buzin }\end{array}$ & $\begin{array}{l}\text { Metsulfuron- } \\
\text { methyl }\end{array}$ & Molinate & $\begin{array}{l}\text { Napro- } \\
\text { pamide }\end{array}$ & Neburon & $\begin{array}{l}\text { Nico- } \\
\text { sulfuron }\end{array}$ & $\begin{array}{c}\text { Norflur- } \\
\text { azon }\end{array}$ & Oryzalin \\
\hline NM03N.36E.28.411 & $<0.011$ & $<0.013$ & $<0.006$ & $<0.025$ & $<0.002$ & $<0.007$ & $<0.01$ & $<0.013$ & $<0.02$ & $<0.02$ \\
\hline NM05N.34E.36.244 & $<.011$ & $<.013$ & $<.006$ & $<.025$ & $<.002$ & $<.007$ & $<.01$ & $<.013$ & $<.02$ & $<.02$ \\
\hline NM13S.38E.14.3333A & $<.011$ & $<.013$ & $<.006$ & $<.025$ & $<.002$ & $<.007$ & $<.01$ & $<.013$ & $<.02$ & $<.02$ \\
\hline NM15S.38E.14.211 & $<.011$ & $<.013$ & $<.006$ & $<.025$ & $<.002$ & $<.007$ & $<.01$ & $<.013$ & $<.02$ & $<.02$ \\
\hline NM01N.36E.21.233 & $<.011$ & $<.013$ & $<.006$ & $<.025$ & $<.002$ & $<.007$ & $<.01$ & $<.013$ & $<.02$ & $<.02$ \\
\hline NM02S.36E.17.231 & $<.011$ & $<.013$ & $<.006$ & $<.025$ & $<.002$ & $<.007$ & $<.01$ & $<.013$ & $<.02$ & $<.02$ \\
\hline AB-27-29-905 & $<.011$ & $<.013$ & $<.006$ & $<.025$ & $<.002$ & $<.007$ & $<.01$ & $<.013$ & $<.02$ & $<.02$ \\
\hline AR-25-08-603 & $<.011$ & $<.013$ & $<.006$ & $<.025$ & $<.002$ & $<.007$ & $<.01$ & $<.013$ & $<.02$ & $<.02$ \\
\hline BL-11-38-925 & $<.011$ & $<.013$ & $<.006$ & $<.025$ & $<.002$ & $<.007$ & $<.01$ & $<.013$ & $<.02$ & $<.02$ \\
\hline DD-10-30-803 & $<.011$ & $<.013$ & $<.006$ & $<.025$ & $<.002$ & $<.007$ & $<.01$ & $<.013$ & $<.02$ & $<.02$ \\
\hline DP-24-19-405 & $<.011$ & $<.013$ & $<.006$ & $<.025$ & $<.002$ & $<.007$ & $<.01$ & $<.013$ & $<.02$ & $<.02$ \\
\hline DP-24-20-705 & $<.011$ & $<.013$ & $<.006$ & $<.025$ & $<.002$ & $<.007$ & $<.01$ & $<.013$ & $<.02$ & $<.02$ \\
\hline HK-23-14-404 & $<.011$ & $<.013$ & $<.006$ & $<.025$ & $<.002$ & $<.007$ & $<.01$ & $<.013$ & $<.02$ & $<.02$ \\
\hline HK-23-29-104 & $<.011$ & $<.013$ & $<.006$ & $<.025$ & $<.002$ & $<.007$ & $<.0014$ & $<.013$ & $<.0011$ & $<.02$ \\
\hline HS-28-09-808 & $<.011$ & $<.013$ & $<.006$ & $<.025$ & $<.002$ & $<.007$ & $<.01$ & $<.013$ & $<.02$ & $<.02$ \\
\hline HS-28-27-411 & $<.011$ & $<.013$ & $<.006$ & $<.025$ & $<.002$ & $<.007$ & $<.01$ & $<.013$ & $<.02$ & $<.02$ \\
\hline HT-10-13-345 & $<.011$ & $<.013$ & $<.006$ & $<.025$ & $<.002$ & $<.007$ & $<.01$ & $<.013$ & $<.02$ & $<.02$ \\
\hline HT-10-13-640 & $<.011$ & $<.013$ & $<.006$ & $<.025$ & $<.002$ & $<.007$ & $<.01$ & $<.013$ & $<.02$ & $<.02$ \\
\hline JW-23-08-101 & $<.011$ & $<.013$ & $<.006$ & $<.025$ & $<.002$ & $<.007$ & $<.01$ & $<.013$ & $<.02$ & $<.02$ \\
\hline KD-26-24-203 & $<.011$ & $<.013$ & $<.006$ & $<.025$ & $<.002$ & $<.007$ & $<.01$ & $<.013$ & $<.02$ & $<.02$ \\
\hline KD-27-01-807 & $<.011$ & $<.013$ & $<.006$ & $<.025$ & $<.002$ & $<.007$ & $<.01$ & $<.013$ & $<.02$ & $<.02$ \\
\hline KD-27-19-518 & $<.011$ & $<.013$ & $<.006$ & $<.025$ & $<.002$ & $<.007$ & $<.01$ & $<.013$ & $<.02$ & $<.02$ \\
\hline KD-27-30-103 & $<.011$ & $<.013$ & $<.006$ & $<.025$ & $<.002$ & $<.007$ & $<.01$ & $<.013$ & $<.02$ & $<.02$ \\
\hline KY-11-43-805 & $<.011$ & $<.013$ & $<.006$ & $<.025$ & $<.002$ & $<.007$ & $<.01$ & $<.013$ & $<.02$ & $<.02$ \\
\hline KY-11-49-207 & $<.011$ & $<.013$ & $<.006$ & $<.025$ & $<.002$ & $<.007$ & $<.01$ & $<.013$ & $<.02$ & $<.02$ \\
\hline KY-23-03-904 & $<.011$ & $<.013$ & $<.006$ & $<.025$ & $<.002$ & $<.007$ & $<.01$ & $<.013$ & $<.02$ & $<.02$ \\
\hline KY-23-10-304 & $<.011$ & $<.013$ & $<.006$ & $<.025$ & $<.002$ & $<.007$ & $<.01$ & $<.013$ & $<.02$ & $<.02$ \\
\hline PB-28-37-307 & $<.011$ & $<.013$ & $<.006$ & $<.025$ & $<.002$ & $<.007$ & $<.01$ & $<.013$ & $<.02$ & $<.02$ \\
\hline RU-10-52-107 & $<.011$ & $<.013$ & $<.006$ & $<.025$ & $<.002$ & $<.007$ & $<.01$ & $<.013$ & $<.02$ & $<.02$ \\
\hline RU-10-55-407 & $<.011$ & $<.013$ & $<.006$ & $<.025$ & $<.002$ & $<.007$ & $<.01$ & $<.013$ & $<.02$ & $<.02$ \\
\hline SP-23-17-712 & $<.011$ & $<.013$ & $<.006$ & $<.025$ & $<.002$ & $<.007$ & $<.01$ & $<.013$ & $<.02$ & $<.02$ \\
\hline SP-23-25-904 & $<.011$ & $<.013$ & $<.006$ & $<.025$ & $<.002$ & $<.007$ & $<.01$ & $<.013$ & $<.02$ & $<.02$ \\
\hline SR-23-41-502 & $<.011$ & $<.013$ & $<.006$ & $<.025$ & $<.002$ & $<.007$ & $<.01$ & $<.013$ & $<.02$ & $<.02$ \\
\hline SY-27-48-611 & $<.011$ & $<.013$ & $<.006$ & $<.025$ & $<.002$ & $<.007$ & $<.01$ & $<.013$ & $<.02$ & $<.02$ \\
\hline SY-28-42-707 & $<.011$ & $<.013$ & $<.006$ & $<.025$ & $<.002$ & $<.007$ & $<.01$ & $<.013$ & $<.02$ & $<.02$ \\
\hline SY-28-58-204 & $<.011$ & $<.013$ & $<.006$ & $<.025$ & $<.002$ & $<.007$ & $<.01$ & $<.013$ & $<.02$ & $<.02$ \\
\hline $\mathrm{UH}-07-53-228$ & $<.011$ & $<.013$ & $<.006$ & $<.025$ & $<.002$ & $<.007$ & $<.01$ & $<.013$ & $<.02$ & $<.02$ \\
\hline UR-10-19-506 & $<.011$ & $<.013$ & $<.006$ & $<.025$ & $<.002$ & $<.007$ & $<.01$ & $<.013$ & $<.02$ & $<.02$ \\
\hline UR-10-42-204 & $<.011$ & $<.013$ & $<.006$ & $<.025$ & $<.002$ & $<.007$ & $<.01$ & $<.013$ & $<.02$ & $<.02$ \\
\hline UY-06-57-824 & $<.011$ & $<.013$ & $<.006$ & $<.025$ & $<.002$ & $<.007$ & $<.01$ & $<.013$ & $<.02$ & $<.02$ \\
\hline UY-10-07-631 & $<.011$ & $<.013$ & $<.006$ & $<.025$ & $<.002$ & $<.007$ & $<.01$ & $<.013$ & $<.02$ & $<.02$ \\
\hline XT-11-44-605 & $<.011$ & $<.013$ & $<.006$ & $<.025$ & $<.002$ & $<.007$ & $<.01$ & $<.013$ & $<.02$ & $<.02$ \\
\hline$X Y-24-45-502$ & $<.011$ & $<.013$ & $<.006$ & $<.025$ & $<.002$ & $<.007$ & $<.01$ & $<.013$ & $<.02$ & $<.02$ \\
\hline$X Y-24-47-207$ & $<.011$ & $<.013$ & $<.006$ & $<.025$ & $<.002$ & $<.007$ & $<.01$ & $<.013$ & $<.02$ & $<.02$ \\
\hline$X Y-24-62-801$ & $<.011$ & $<.013$ & $<.006$ & $<.025$ & $<.002$ & $<.007$ & $<.01$ & $<.013$ & $<.02$ & $<.02$ \\
\hline ZT-24-43-202 & $<.011$ & $<.013$ & $<.006$ & $<.025$ & $<.002$ & $<.007$ & $<.01$ & $<.013$ & $<.02$ & $<.02$ \\
\hline ZT-24-50-602 & $<.011$ & $<.013$ & $<.006$ & $<.025$ & $<.002$ & $<.007$ & $<.01$ & $<.013$ & $<.02$ & $<.02$ \\
\hline ZT-25-40-804 & $<.011$ & $<.013$ & $<.006$ & $<.025$ & $<.002$ & $<.007$ & $<.01$ & $<.013$ & $<.02$ & $<.02$ \\
\hline
\end{tabular}


Appendix 6. Pesticide concentrations in water sampled from primarily domestic wells screened in the southern High Plains aquifer, Texas and New Mexico, 2001-Continued

\begin{tabular}{|c|c|c|c|c|c|c|c|c|c|c|}
\hline $\begin{array}{c}\text { State } \\
\text { well no. }\end{array}$ & Oxamyl & $\begin{array}{l}\text { Oxamyl } \\
\text { oxime }\end{array}$ & $\begin{array}{l}p, p^{\prime}- \\
\text { DDE }\end{array}$ & Parathion & $\begin{array}{c}\text { Parathion, } \\
\text { methyl- }\end{array}$ & Pebulate & $\begin{array}{c}\text { Pendi- } \\
\text { methalin }\end{array}$ & $\begin{array}{l}\text { Perme- } \\
\text { thrin }\end{array}$ & Phorate & Picloram \\
\hline NM03N.36E.28.411 & $<0.01$ & $<0.013$ & $<0.003$ & $<0.007$ & $<0.006$ & $<0.002$ & $<0.01$ & $<0.006$ & $<0.011$ & $<0.02$ \\
\hline NM05N.34E.36.244 & $<.01$ & $<.013$ & $<.003$ & $<.007$ & $<.006$ & $<.002$ & $<.01$ & $<.006$ & $<.011$ & $<.02$ \\
\hline NM13S.38E.14.3333A & $<.01$ & $<.013$ & $<.003$ & $<.007$ & $<.006$ & $<.002$ & $<.01$ & $<.006$ & $<.011$ & $<.02$ \\
\hline NM15S.38E.14.211 & $<.01$ & $<.013$ & $<.003$ & $<.007$ & $<.006$ & $<.002$ & $<.01$ & $<.006$ & $<.011$ & $<.02$ \\
\hline NM01N.36E.21.233 & $<.01$ & $<.013$ & $<.003$ & $<.007$ & $<.006$ & $<.002$ & $<.01$ & $<.006$ & $<.011$ & $<.02$ \\
\hline NM02S.36E.17.231 & $<.01$ & $<.013$ & $<.003$ & $<.007$ & $<.006$ & $<.002$ & $<.01$ & $<.006$ & $<.011$ & $<.02$ \\
\hline AB-27-29-905 & $<.01$ & $<.013$ & $<.003$ & $<.007$ & $<.006$ & $<.002$ & $<.01$ & $<.006$ & $<.011$ & $<.02$ \\
\hline AR-25-08-603 & $<.01$ & $<.013$ & $<.003$ & $<.007$ & $<.006$ & $<.002$ & $<.01$ & $<.006$ & $<.011$ & $<.02$ \\
\hline BL-11-38-925 & $<.01$ & $<.013$ & $<.003$ & $<.007$ & $<.006$ & $<.002$ & $<.01$ & $<.006$ & $<.011$ & $<.02$ \\
\hline DD-10-30-803 & $<.01$ & $<.013$ & $<.003$ & $<.007$ & $<.006$ & $<.002$ & $<.01$ & $<.006$ & $<.011$ & $<.02$ \\
\hline DP-24-19-405 & $<.01$ & $<.013$ & $<.003$ & $<.007$ & $<.006$ & $<.002$ & $<.01$ & $<.006$ & $<.011$ & $<.02$ \\
\hline DP-24-20-705 & $<.01$ & $<.013$ & $<.003$ & $<.007$ & $<.006$ & $<.002$ & $<.01$ & $<.006$ & $<.011$ & $<.02$ \\
\hline HK-23-14-404 & $<.01$ & $<.013$ & $<.003$ & $<.007$ & $<.006$ & $<.002$ & $<.01$ & $<.006$ & $<.011$ & $<.02$ \\
\hline HK-23-29-104 & $<.01$ & $<.013$ & $<.003$ & $<.007$ & $<.006$ & $<.002$ & $<.01$ & $<.006$ & $<.011$ & $<.02$ \\
\hline HS-28-09-808 & $<.01$ & $<.013$ & $<.003$ & $<.007$ & $<.006$ & $<.002$ & $<.01$ & $<.006$ & $<.011$ & $<.02$ \\
\hline HS-28-27-411 & $<.01$ & $<.013$ & $<.003$ & $<.007$ & $<.006$ & $<.002$ & $<.01$ & $<.006$ & $<.011$ & $<.02$ \\
\hline HT-10-13-345 & $<.01$ & $<.013$ & $<.003$ & $<.007$ & $<.006$ & $<.002$ & $<.01$ & $<.006$ & $<.011$ & $<.02$ \\
\hline HT-10-13-640 & $<.01$ & $<.013$ & $<.003$ & $<.007$ & $<.006$ & $<.002$ & $<.01$ & $<.006$ & $<.011$ & $<.02$ \\
\hline JW-23-08-101 & $<.01$ & $<.013$ & $<.003$ & $<.007$ & $<.006$ & $<.002$ & $<.01$ & $<.006$ & $<.011$ & $<.02$ \\
\hline KD-26-24-203 & $<.01$ & $<.013$ & $<.003$ & $<.007$ & $<.006$ & $<.002$ & $<.01$ & $<.006$ & $<.011$ & $<.02$ \\
\hline KD-27-01-807 & $<.01$ & $<.013$ & $<.003$ & $<.007$ & $<.006$ & $<.002$ & $<.01$ & $<.006$ & $<.011$ & $<.02$ \\
\hline KD-27-19-518 & $<.01$ & $<.013$ & $<.003$ & $<.007$ & $<.006$ & $<.002$ & $<.01$ & $<.006$ & $<.011$ & $<.02$ \\
\hline KD-27-30-103 & $<.01$ & $<.013$ & $<.003$ & $<.007$ & $<.006$ & $<.002$ & $<.01$ & $<.006$ & $<.011$ & $<.02$ \\
\hline KY-11-43-805 & $<.01$ & $<.013$ & $<.003$ & $<.007$ & $<.006$ & $<.002$ & $<.01$ & $<.006$ & $<.011$ & $<.02$ \\
\hline KY-11-49-207 & $<.01$ & $<.013$ & $<.003$ & $<.007$ & $<.006$ & $<.002$ & $<.01$ & $<.006$ & $<.011$ & $<.02$ \\
\hline KY-23-03-904 & $<.01$ & $<.013$ & $<.003$ & $<.007$ & $<.006$ & $<.002$ & $<.01$ & $<.006$ & $<.011$ & $<.02$ \\
\hline KY $-23-10-304$ & $<.01$ & $<.013$ & $<.003$ & $<.007$ & $<.006$ & $<.002$ & $<.01$ & $<.006$ & $<.011$ & $<.02$ \\
\hline PB-28-37-307 & $<.01$ & $<.013$ & $<.003$ & $<.007$ & $<.006$ & $<.002$ & $<.01$ & $<.006$ & $<.011$ & $<.02$ \\
\hline RU-10-52-107 & $<.01$ & $<.013$ & $<.003$ & $<.007$ & $<.006$ & $<.002$ & $<.01$ & $<.006$ & $<.011$ & $<.02$ \\
\hline RU-10-55-407 & $<.01$ & $<.013$ & $<.003$ & $<.007$ & $<.006$ & $<.002$ & $<.01$ & $<.006$ & $<.011$ & $<.02$ \\
\hline SP-23-17-712 & $<.01$ & $<.013$ & $<.003$ & $<.007$ & $<.006$ & $<.002$ & $<.01$ & $<.006$ & $<.011$ & $<.02$ \\
\hline SP-23-25-904 & $<.01$ & $<.013$ & $<.003$ & $<.007$ & $<.006$ & $<.002$ & $<.01$ & $<.006$ & $<.011$ & $<.02$ \\
\hline SR-23-41-502 & $<.01$ & $<.013$ & $<.003$ & $<.007$ & $<.006$ & $<.002$ & $<.01$ & $<.006$ & $<.011$ & $<.02$ \\
\hline SY $-27-48-611$ & $<.01$ & $<.013$ & $<.003$ & $<.007$ & $<.006$ & $<.002$ & $<.01$ & $<.006$ & $<.011$ & $<.02$ \\
\hline SY $-28-42-707$ & $<.01$ & $<.013$ & $<.003$ & $<.007$ & $<.006$ & $<.002$ & $<.01$ & $<.006$ & $<.011$ & $<.02$ \\
\hline SY-28-58-204 & $<.01$ & $<.013$ & $<.003$ & $<.007$ & $<.006$ & $<.002$ & $<.01$ & $<.006$ & $<.011$ & $<.02$ \\
\hline $\mathrm{UH}-07-53-228$ & $<.01$ & $<.013$ & $<.003$ & $<.007$ & $<.006$ & $<.002$ & $<.01$ & $<.006$ & $<.011$ & $<.02$ \\
\hline UR-10-19-506 & $<.01$ & $<.013$ & $<.003$ & $<.007$ & $<.006$ & $<.002$ & $<.01$ & $<.006$ & $<.011$ & $<.02$ \\
\hline UR-10-42-204 & $<.01$ & $<.013$ & $<.003$ & $<.007$ & $<.006$ & $<.002$ & $<.01$ & $<.006$ & $<.011$ & $<.02$ \\
\hline UY-06-57-824 & $<.01$ & $<.013$ & $<.003$ & $<.007$ & $<.006$ & $<.002$ & $<.01$ & $<.006$ & $<.011$ & $<.02$ \\
\hline UY-10-07-631 & $<.01$ & $<.013$ & $<.003$ & $<.007$ & $<.006$ & $<.002$ & $<.01$ & $<.006$ & $<.011$ & $<.02$ \\
\hline XT-11-44-605 & $<.01$ & $<.013$ & $<.003$ & $<.007$ & $<.006$ & $<.002$ & $<.01$ & $<.006$ & $<.011$ & $<.02$ \\
\hline$X Y-24-45-502$ & $<.01$ & $<.013$ & $<.003$ & $<.007$ & $<.006$ & $<.002$ & $<.01$ & $<.006$ & $<.011$ & $<.02$ \\
\hline$X Y-24-47-207$ & $<.01$ & $<.013$ & $<.003$ & $<.007$ & $<.006$ & $<.002$ & $<.01$ & $<.006$ & $<.011$ & $<.02$ \\
\hline $\mathrm{XY}-24-62-801$ & $<.01$ & $<.013$ & $<.003$ & $<.007$ & $<.006$ & $<.002$ & $<.01$ & $<.006$ & $<.011$ & $<.02$ \\
\hline ZT-24-43-202 & $<.01$ & $<.013$ & $<.003$ & $<.007$ & $<.006$ & $<.002$ & $<.01$ & $<.006$ & $<.011$ & $<.02$ \\
\hline ZT-24-50-602 & $<.01$ & $<.013$ & $<.003$ & $<.007$ & $<.006$ & $<.002$ & $<.01$ & $<.006$ & $<.011$ & $<.02$ \\
\hline ZT-25-40-804 & $<.01$ & $<.013$ & $<.003$ & $<.007$ & $<.006$ & $<.002$ & $<.01$ & $<.006$ & $<.011$ & $<.02$ \\
\hline
\end{tabular}


Appendix 6. Pesticide concentrations in water sampled from primarily domestic wells screened in the southern High Plains aquifer, Texas and New Mexico, 2001-Continued

\begin{tabular}{|c|c|c|c|c|c|c|c|c|c|c|}
\hline $\begin{array}{c}\text { State } \\
\text { well no. }\end{array}$ & Prometon & $\begin{array}{l}\text { Prona- } \\
\text { mide }\end{array}$ & $\begin{array}{l}\text { Propa- } \\
\text { chlor }\end{array}$ & Propanil & $\begin{array}{l}\text { Prop- } \\
\text { argite }\end{array}$ & Propham & $\begin{array}{l}\text { Propicon- } \\
\text { azole }\end{array}$ & Propoxur & Siduron & Simazine \\
\hline & & $\begin{array}{c}\text { Propyz- } \\
\text { amide }\end{array}$ & & & & & & & & \\
\hline NM03N.36E.28.411 & $<0.015$ & $<0.004$ & $<0.01$ & $<0.011$ & $<0.023$ & $<0.01$ & $<0.021$ & $<0.01$ & $<0.017$ & $<0.011$ \\
\hline NM05N.34E.36.244 & $<.015$ & $<.004$ & $<.01$ & $<.011$ & $<.023$ & $<.01$ & $<.002$ & $<.01$ & $<.017$ & $<.011$ \\
\hline NM13S.38E.14.3333A & $<.015$ & $<.004$ & $<.01$ & $<.011$ & $<.023$ & $<.01$ & $<.021$ & $<.01$ & $<.017$ & $<.011$ \\
\hline NM15S.38E.14.211 & $<.015$ & $<.004$ & $<.01$ & $<.011$ & $<.023$ & $<.01$ & $<.021$ & $<.01$ & $<.017$ & $<.011$ \\
\hline NM01N.36E.21.233 & $<.015$ & $<.004$ & $<.01$ & $<.011$ & $<.023$ & $<.01$ & $<.021$ & $<.01$ & $<.017$ & $<.011$ \\
\hline NM02S.36E.17.231 & $<.015$ & $<.004$ & $<.01$ & $<.011$ & $<.023$ & $<.01$ & $<.021$ & $<.01$ & $<.017$ & $<.011$ \\
\hline AB-27-29-905 & $<.015$ & $<.004$ & $<.01$ & $<.011$ & $<.023$ & $<.01$ & $<.005$ & $<.01$ & $<.017$ & $<.011$ \\
\hline AR-25-08-603 & $<.015$ & $<.004$ & $<.01$ & $<.011$ & $<.023$ & $<.01$ & $<.021$ & $<.01$ & $<.017$ & $<.011$ \\
\hline BL-11-38-925 & $<.015$ & $<.004$ & $<.01$ & $<.011$ & $<.023$ & $<.01$ & $<.021$ & $<.01$ & $<.017$ & $<.011$ \\
\hline DD-10-30-803 & $<.015$ & $<.004$ & $<.01$ & $<.011$ & $<.023$ & $<.01$ & $<.021$ & $<.01$ & $<.017$ & $<.011$ \\
\hline DP-24-19-405 & $<.015$ & $<.004$ & $<.01$ & $<.011$ & $<.023$ & $<.01$ & $<.002$ & $<.01$ & $<.017$ & $<.011$ \\
\hline DP-24-20-705 & $<.015$ & $<.004$ & $<.01$ & $<.011$ & $<.023$ & $<.01$ & $<.001$ & $<.01$ & $<.017$ & $<.011$ \\
\hline HK-23-14-404 & $<.015$ & $<.004$ & $<.01$ & $<.011$ & $<.023$ & $<.01$ & $<.0004$ & $<.01$ & $<.017$ & $<.011$ \\
\hline HK-23-29-104 & $<.015$ & $<.004$ & $<.01$ & $<.011$ & $<.023$ & $<.01$ & $<.021$ & $<.01$ & $<.017$ & $<.011$ \\
\hline HS-28-09-808 & $<.015$ & $<.004$ & $<.01$ & $<.011$ & $<.023$ & $<.01$ & $<.006$ & $<.01$ & $<.017$ & $<.011$ \\
\hline HS-28-27-411 & $<.015$ & $<.004$ & $<.01$ & $<.011$ & $<.023$ & $<.01$ & $<.001$ & $<.01$ & $<.017$ & $<.011$ \\
\hline HT-10-13-345 & $<.015$ & $<.004$ & $<.01$ & $<.011$ & $<.023$ & $<.01$ & $<.021$ & $<.01$ & $<.017$ & $<.011$ \\
\hline HT-10-13-640 & $<.015$ & $<.004$ & $<.01$ & $<.011$ & $<.023$ & $<.01$ & $<.021$ & $<.01$ & $<.017$ & $<.011$ \\
\hline JW-23-08-101 & $<.015$ & $<.004$ & $<.01$ & $<.011$ & $<.023$ & $<.01$ & $<.024$ & $<.01$ & $<.017$ & $<.011$ \\
\hline KD-26-24-203 & $<.015$ & $<.004$ & $<.01$ & $<.011$ & $<.023$ & $<.01$ & $<.021$ & $<.01$ & $<.017$ & $<.011$ \\
\hline KD-27-01-807 & $<.015$ & $<.004$ & $<.01$ & $<.011$ & $<.023$ & $<.01$ & $<.001$ & $<.01$ & $<.017$ & $<.011$ \\
\hline KD-27-19-518 & $<.015$ & $<.004$ & $<.01$ & $<.011$ & $<.023$ & $<.01$ & $<.001$ & $<.01$ & $<.017$ & $<.011$ \\
\hline KD-27-30-103 & $<.015$ & $<.004$ & $<.01$ & $<.011$ & $<.023$ & $<.01$ & $<.008$ & $<.01$ & $<.017$ & $<.011$ \\
\hline KY-11-43-805 & $<.015$ & $<.004$ & $<.01$ & $<.011$ & $<.023$ & $<.01$ & $<.021$ & $<.01$ & $<.017$ & $<.011$ \\
\hline KY-11-49-207 & $<.015$ & $<.004$ & $<.01$ & $<.011$ & $<.023$ & $<.01$ & $<.021$ & $<.01$ & $<.017$ & $<.011$ \\
\hline KY-23-03-904 & $<.015$ & $<.004$ & $<.01$ & $<.011$ & $<.023$ & $<.01$ & $<.021$ & $<.01$ & $<.017$ & $<.011$ \\
\hline KY-23-10-304 & $<.015$ & $<.004$ & $<.01$ & $<.011$ & $<.023$ & $<.01$ & $<.021$ & $<.01$ & $<.017$ & $<.011$ \\
\hline PB-28-37-307 & $<.015$ & $<.004$ & $<.01$ & $<.011$ & $<.023$ & $<.01$ & $<.021$ & $<.01$ & $<.017$ & $<.011$ \\
\hline RU-10-52-107 & $<.015$ & $<.004$ & $<.01$ & $<.011$ & $<.023$ & $<.01$ & $<.021$ & $<.01$ & $<.017$ & $<.011$ \\
\hline RU-10-55-407 & $<.015$ & $<.004$ & $<.01$ & $<.011$ & $<.023$ & $<.01$ & $<.021$ & $<.01$ & $<.017$ & $<.011$ \\
\hline SP-23-17-712 & $<.015$ & $<.004$ & $<.01$ & $<.011$ & $<.023$ & $<.01$ & $<.021$ & $<.01$ & $<.017$ & $<.011$ \\
\hline SP-23-25-904 & $<.015$ & $<.004$ & $<.01$ & $<.011$ & $<.023$ & $<.01$ & $<.021$ & $<.01$ & $<.017$ & $<.011$ \\
\hline SR-23-41-502 & $<.015$ & $<.004$ & $<.01$ & $<.011$ & $<.023$ & $<.01$ & $<.021$ & $<.01$ & $<.017$ & $<.011$ \\
\hline SY-27-48-611 & $<.015$ & $<.004$ & $<.01$ & $<.011$ & $<.023$ & $<.01$ & $<.007$ & $<.01$ & $<.017$ & $<.011$ \\
\hline SY-28-42-707 & $<.015$ & $<.004$ & $<.01$ & $<.011$ & $<.023$ & $<.01$ & $<.021$ & $<.01$ & $<.017$ & $<.011$ \\
\hline SY-28-58-204 & $<.015$ & $<.004$ & $<.01$ & $<.011$ & $<.023$ & $<.01$ & $<.021$ & $<.01$ & $<.017$ & $<.011$ \\
\hline $\mathrm{UH}-07-53-228$ & $<.015$ & $<.004$ & $<.01$ & $<.011$ & $<.023$ & $<.01$ & $<.021$ & $<.01$ & $<.017$ & $<.011$ \\
\hline UR-10-19-506 & $<.015$ & $<.004$ & $<.01$ & $<.011$ & $<.023$ & $<.01$ & $<.021$ & $<.01$ & $<.017$ & $<.011$ \\
\hline UR-10-42-204 & $<.015$ & $<.004$ & $<.01$ & $<.011$ & $<.023$ & $<.01$ & $<.021$ & $<.01$ & $<.017$ & $<.011$ \\
\hline UY-06-57-824 & $<.015$ & $<.004$ & $<.01$ & $<.011$ & $<.023$ & $<.01$ & $<.021$ & $<.01$ & $<.017$ & $<.011$ \\
\hline UY-10-07-631 & $<.015$ & $<.004$ & $<.01$ & $<.011$ & $<.023$ & $<.01$ & $<.021$ & $<.01$ & $<.017$ & $<.011$ \\
\hline XT-11-44-605 & $<.015$ & $<.004$ & $<.01$ & $<.011$ & $<.023$ & $<.01$ & $<.021$ & $<.01$ & $<.017$ & $<.011$ \\
\hline XY-24-45-502 & $<.015$ & $<.004$ & $<.01$ & $<.011$ & $<.023$ & $<.01$ & $<.002$ & $<.01$ & $<.017$ & $<.011$ \\
\hline XY-24-47-207 & $<.015$ & $<.004$ & $<.01$ & $<.011$ & $<.023$ & $<.01$ & $<.021$ & $<.01$ & $<.017$ & $<.011$ \\
\hline XY-24-62-801 & $<.015$ & $<.004$ & $<.01$ & $<.011$ & $<.023$ & $<.01$ & $<.021$ & $<.01$ & $<.017$ & $<.011$ \\
\hline ZT-24-43-202 & $<.015$ & $<.004$ & $<.01$ & $<.011$ & $<.023$ & $<.01$ & $<.021$ & $<.01$ & $<.017$ & $<.011$ \\
\hline ZT-24-50-602 & $<.015$ & $<.004$ & $<.01$ & $<.011$ & $<.023$ & $<.01$ & $<.021$ & $<.01$ & $<.017$ & $<.011$ \\
\hline ZT-25-40-804 & $<.015$ & $<.004$ & $<.01$ & $<.011$ & $<.023$ & $<.01$ & $<.021$ & $<.01$ & $<.017$ & $<.011$ \\
\hline
\end{tabular}


Appendix 6. Pesticide concentrations in water sampled from primarily domestic wells screened in the southern High Plains aquifer, Texas and New Mexico, 2001—Continued

\begin{tabular}{|c|c|c|c|c|c|c|c|c|c|}
\hline $\begin{array}{c}\text { State } \\
\text { well no. }\end{array}$ & $\begin{array}{c}\text { Sulfo- } \\
\text { meturon- } \\
\text { methyl }\end{array}$ & $\begin{array}{l}\text { Tebuthi- } \\
\text { uron }\end{array}$ & Terbacil & Terbufos & $\begin{array}{l}\text { Thioben- } \\
\text { carb }\end{array}$ & Triallate & $\begin{array}{l}\text { Triben- } \\
\text { uron- } \\
\text { methyl }\end{array}$ & Triclopyr & $\begin{array}{l}\text { Triflur- } \\
\text { alin }\end{array}$ \\
\hline NM03N.36E.28.411 & $<0.009$ & $<0.016$ & $<0.01$ & $<0.017$ & $<0.005$ & $<0.002$ & $<0.01$ & $<0.02$ & $<0.009$ \\
\hline NM05N.34E.36.244 & $<.009$ & $<.016$ & $<.034$ & $<.017$ & $<.005$ & $<.002$ & $<.01$ & $<.02$ & $<.009$ \\
\hline NM13S.38E.14.3333A & $<.009$ & $<.016$ & $<.034$ & $<.017$ & $<.005$ & $<.002$ & $<.01$ & $<.02$ & $<.009$ \\
\hline NM15S.38E.14.211 & $<.009$ & $<.016$ & $<.034$ & $<.017$ & $<.005$ & $<.002$ & $<.01$ & $<.02$ & $<.009$ \\
\hline NM01N.36E.21.233 & $<.009$ & $<.006$ & $<.034$ & $<.017$ & $<.005$ & $<.002$ & $<.01$ & $<.02$ & $<.009$ \\
\hline NM02S.36E.17.231 & $<.009$ & $<.016$ & $<.034$ & $<.017$ & $<.005$ & $<.002$ & $<.01$ & $<.02$ & $<.009$ \\
\hline AB-27-29-905 & $<.009$ & $<.016$ & $<.034$ & $<.017$ & $<.005$ & $<.002$ & $<.01$ & $<.02$ & $<.009$ \\
\hline AR-25-08-603 & $<.009$ & $<.006$ & $<.034$ & $<.017$ & $<.005$ & $<.002$ & $<.01$ & $<.02$ & $<.009$ \\
\hline BL-11-38-925 & $<.009$ & $<.016$ & $<.01$ & $<.017$ & $<.005$ & $<.002$ & $<.01$ & $<.02$ & $<.009$ \\
\hline DD-10-30-803 & $<.009$ & $<.006$ & $<.01$ & $<.017$ & $<.005$ & $<.002$ & $<.01$ & $<.02$ & $<.009$ \\
\hline DP-24-19-405 & $<.009$ & $<.016$ & $<.01$ & $<.017$ & $<.005$ & $<.002$ & $<.01$ & $<.02$ & $<.009$ \\
\hline DP-24-20-705 & $<.009$ & $<.016$ & $<.034$ & $<.017$ & $<.005$ & $<.002$ & $<.01$ & $<.02$ & $<.009$ \\
\hline HK-23-14-404 & $<.009$ & $<.016$ & $<.034$ & $<.017$ & $<.005$ & $<.002$ & $<.01$ & $<.02$ & $<.009$ \\
\hline HK-23-29-104 & $<.009$ & $<.016$ & $<.01$ & $<.017$ & $<.005$ & $<.002$ & $<.01$ & $<.02$ & $<.009$ \\
\hline HS-28-09-808 & $<.009$ & $<.016$ & $<.034$ & $<.017$ & $<.005$ & $<.002$ & $<.01$ & $<.02$ & $<.009$ \\
\hline HS-28-27-411 & $<.009$ & $<.016$ & $<.01$ & $<.017$ & $<.005$ & $<.002$ & $<.01$ & $<.02$ & $<.009$ \\
\hline HT-10-13-345 & $<.009$ & $<.016$ & $<.01$ & $<.017$ & $<.005$ & $<.002$ & $<.01$ & $<.02$ & $<.009$ \\
\hline HT-10-13-640 & $<.009$ & $<.006$ & $<.01$ & $<.017$ & $<.005$ & $<.002$ & $<.01$ & $<.02$ & $<.009$ \\
\hline JW-23-08-101 & $<.009$ & $<.016$ & $<.01$ & $<.017$ & $<.005$ & $<.002$ & $<.01$ & $<.02$ & $<.009$ \\
\hline KD-26-24-203 & $<.009$ & $<.016$ & $<.01$ & $<.017$ & $<.005$ & $<.002$ & $<.01$ & $<.02$ & $<.009$ \\
\hline KD-27-01-807 & $<.009$ & $<.016$ & $<.034$ & $<.017$ & $<.005$ & $<.002$ & $<.01$ & $<.02$ & $<.009$ \\
\hline KD-27-19-518 & $<.009$ & $<.016$ & $<.034$ & $<.017$ & $<.005$ & $<.002$ & $<.01$ & $<.02$ & $<.009$ \\
\hline KD-27-30-103 & $<.009$ & $<.016$ & $<.01$ & $<.017$ & $<.005$ & $<.002$ & $<.01$ & $<.02$ & $<.009$ \\
\hline KY-11-43-805 & $<.009$ & $<.016$ & $<.01$ & $<.017$ & $<.005$ & $<.002$ & $<.01$ & $<.02$ & $<.009$ \\
\hline KY-11-49-207 & $<.009$ & $<.006$ & $<.034$ & $<.017$ & $<.005$ & $<.002$ & $<.01$ & $<.02$ & $<.009$ \\
\hline KY-23-03-904 & $<.009$ & $<.006$ & $<.034$ & $<.017$ & $<.005$ & $<.002$ & $<.01$ & $<.02$ & $<.009$ \\
\hline KY-23-10-304 & $<.009$ & $<.006$ & $<.01$ & $<.017$ & $<.005$ & $<.002$ & $<.01$ & $<.02$ & $<.009$ \\
\hline PB-28-37-307 & $<.009$ & $<.016$ & $<.01$ & $<.017$ & $<.005$ & $<.002$ & $<.01$ & $<.02$ & $<.009$ \\
\hline RU-10-52-107 & $<.009$ & $<.006$ & $<.034$ & $<.017$ & $<.005$ & $<.002$ & $<.01$ & $<.02$ & $<.009$ \\
\hline RU-10-55-407 & $<.009$ & $<.016$ & $<.01$ & $<.017$ & $<.005$ & $<.002$ & $<.01$ & $<.02$ & $<.009$ \\
\hline SP-23-17-712 & $<.001$ & $<.016$ & $<.01$ & $<.017$ & $<.005$ & $<.002$ & $<.01$ & $<.02$ & $<.009$ \\
\hline SP-23-25-904 & $<.009$ & $<.016$ & $<.034$ & $<.017$ & $<.005$ & $<.002$ & $<.01$ & $<.02$ & $<.009$ \\
\hline SR-23-41-502 & $<.009$ & $<.016$ & $<.01$ & $<.017$ & $<.005$ & $<.002$ & $<.01$ & $<.02$ & $<.009$ \\
\hline SY-27-48-611 & $<.009$ & $<.016$ & $<.034$ & $<.017$ & $<.005$ & $<.002$ & $<.01$ & $<.02$ & $<.009$ \\
\hline SY-28-42-707 & $<.009$ & $<.016$ & $<.01$ & $<.017$ & $<.005$ & $<.002$ & $<.01$ & $<.02$ & $<.009$ \\
\hline SY-28-58-204 & $<.009$ & $<.016$ & $<.034$ & $<.017$ & $<.005$ & $<.002$ & $<.01$ & $<.02$ & $<.009$ \\
\hline $\mathrm{UH}-07-53-228$ & $<.009$ & $<.016$ & $<.034$ & $<.017$ & $<.005$ & $<.002$ & $<.01$ & $<.02$ & $<.009$ \\
\hline UR-10-19-506 & $<.009$ & $<.016$ & $<.034$ & $<.017$ & $<.005$ & $<.002$ & $<.01$ & $<.02$ & $<.009$ \\
\hline UR-10-42-204 & $<.009$ & $<.016$ & $<.01$ & $<.017$ & $<.005$ & $<.002$ & $<.01$ & $<.02$ & $<.009$ \\
\hline UY-06-57-824 & $<.009$ & $<.016$ & $<.01$ & $<.017$ & $<.005$ & $<.002$ & $<.01$ & $<.02$ & $<.009$ \\
\hline UY-10-07-631 & $<.009$ & $<.016$ & $<.01$ & $<.017$ & $<.005$ & $<.002$ & $<.01$ & $<.02$ & $<.009$ \\
\hline XT-11-44-605 & $<.009$ & $<.016$ & $<.034$ & $<.017$ & $<.005$ & $<.002$ & $<.01$ & $<.02$ & $<.009$ \\
\hline$X Y-24-45-502$ & $<.009$ & $<.016$ & $<.034$ & $<.017$ & $<.005$ & $<.002$ & $<.01$ & $<.02$ & $<.009$ \\
\hline$X Y-24-47-207$ & $<.009$ & $<.016$ & $<.034$ & $<.017$ & $<.005$ & $<.002$ & $<.01$ & $<.02$ & $<.009$ \\
\hline$X Y-24-62-801$ & $<.009$ & $<.016$ & $<.01$ & $<.017$ & $<.005$ & $<.002$ & $<.01$ & $<.02$ & $<.009$ \\
\hline ZT-24-43-202 & $<.009$ & $<.016$ & $<.034$ & $<.017$ & $<.005$ & $<.002$ & $<.01$ & $<.02$ & $<.009$ \\
\hline ZT-24-50-602 & $<.001$ & $<.016$ & $<.034$ & $<.017$ & $<.005$ & $<.002$ & $<.01$ & $<.02$ & $<.009$ \\
\hline ZT-25-40-804 & $<.009$ & $<.016$ & $<.01$ & $<.017$ & $<.005$ & $<.002$ & $<.01$ & $<.02$ & $<.009$ \\
\hline
\end{tabular}


Appendix 7. Volatile organic compound concentrations in water sampled from primarily domestic wells screened in the south High Plains aquifer, Texas and New Mexico, 2001

[Other compound name (if applicable) listed below compound name; concentrations are in micrograms per liter; <, less than; E, estimated; --, not measured; M, detected, but not quantified]

\begin{tabular}{|c|c|c|c|c|c|c|c|c|c|c|c|c|c|}
\hline $\begin{array}{c}\text { State } \\
\text { well no. }\end{array}$ & $\begin{array}{l}\text { Sample } \\
\text { date }\end{array}$ & $\begin{array}{l}\text { 2-Butene, } \\
\text { trans-1,4- } \\
\text { dichloro- }\end{array}$ & $\begin{array}{c}\text { 2-Hexa- } \\
\text { none }\end{array}$ & $\begin{array}{l}\text { Ace- } \\
\text { tone }\end{array}$ & $\begin{array}{c}\text { Acrylo- } \\
\text { nitrile }\end{array}$ & $\begin{array}{l}\text { Ben- } \\
\text { zene }\end{array}$ & $\begin{array}{c}\text { Benzene, } \\
1,2,3- \\
\text { trichloro- }\end{array}$ & $\begin{array}{c}\text { Benzene, } \\
1,2,4- \\
\text { trichloro- }\end{array}$ & $\begin{array}{c}\text { Benzene, } \\
1,2,3- \\
\text { trimethyl- }\end{array}$ & $\begin{array}{c}\text { Benzene, } \\
1,2,4- \\
\text { trimethyl- }\end{array}$ & $\begin{array}{c}\text { Benzene, } \\
1,3,5- \\
\text { - trimethyl- }\end{array}$ & $\begin{array}{c}\text { Benzene, } \\
\text { bromo- }\end{array}$ & $\begin{array}{c}\text { Benzene, } \\
\text { chloro- }\end{array}$ \\
\hline & & & & & $\begin{array}{l}\text { 2-prope- } \\
\text { nenitrile }\end{array}$ & & & & & & & & \\
\hline NM03N.36E.28.411 & $08 / 24 / 01$ & $<0.7$ & $<0.7$ & $<7$ & $<1$ & $<0.04$ & $<0.3$ & $<0.2$ & $<0.1$ & $<0.06$ & $<0.04$ & $<0.04$ & $<0.03$ \\
\hline NM05N.34E.36.244 & 09/23/01 & $<.7$ & $<.7$ & $<7$ & $<1$ & $<.04$ & $<.3$ & $<.2$ & $<.1$ & $<.06$ & $<.04$ & $<.04$ & $<.03$ \\
\hline NM13S.38E.14.3333A & 09/25/01 & $<.7$ & $<.7$ & $<7$ & $<1$ & $<.04$ & $<.3$ & $<.2$ & $<.1$ & $<.06$ & $<.04$ & $<.04$ & $<.03$ \\
\hline NM15S.38E.14.211 & 08/11/01 & $<.7$ & $<.7$ & $<7$ & $<1$ & $<.04$ & $<.3$ & $<.2$ & $<.1$ & $<.06$ & $<.04$ & $<.04$ & $<.03$ \\
\hline NM01N.36E.21.233 & $09 / 23 / 01$ & $<.7$ & $<.7$ & $<7$ & $<1$ & $<.04$ & $<.3$ & $<.2$ & $<.1$ & $<.06$ & $<.04$ & $<.04$ & $<.03$ \\
\hline NM02S.36E.17.231 & $08 / 24 / 01$ & $<.7$ & $<.7$ & $<7$ & $<1$ & $<.04$ & $<.3$ & $<.2$ & $<.1$ & $<.06$ & $<.04$ & $<.04$ & $<.03$ \\
\hline AB-27-29-905 & 08/13/01 & $<.7$ & $<.7$ & $<7$ & $<1$ & $<.04$ & $<.3$ & $<.2$ & $<.1$ & $<.06$ & $<.04$ & $<.04$ & $<.03$ \\
\hline AR-25-08-603 & 09/22/01 & $<.7$ & $<.7$ & $<7$ & $<1$ & $<.04$ & $<.3$ & $<.2$ & $<.1$ & $<.06$ & $<.04$ & $<.04$ & $<.03$ \\
\hline BL-11-38-925 & 08/19/01 & $<.7$ & $<.7$ & $<7$ & $<1$ & $<.04$ & $<.3$ & $<.2$ & $<.1$ & $<.06$ & $<.04$ & $<.04$ & $<.03$ \\
\hline DD-10-30-803 & 09/21/01 & $<.7$ & $<.7$ & $<7$ & $<1$ & $<.04$ & $<.3$ & $<.2$ & $<.1$ & $<.06$ & $<.04$ & $<.04$ & $<.03$ \\
\hline DP-24-19-405 & 09/24/01 & $<.7$ & $<.7$ & $<7$ & $<1$ & $<.04$ & $<.3$ & $<.2$ & $<.1$ & $<.06$ & $<.04$ & $<.04$ & $<.03$ \\
\hline DP-24-20-705 & 09/24/01 & $<.7$ & $<.7$ & $<7$ & $<1$ & $<.04$ & $<.3$ & $<.2$ & $<.1$ & $<.06$ & $<.04$ & $<.04$ & $<.03$ \\
\hline HK-23-14-404 & 08/18/01 & $<.7$ & $<.7$ & $<7$ & $<1$ & $<.04$ & $<.3$ & $<.2$ & $<.1$ & $<.06$ & $<.04$ & $<.04$ & $<.03$ \\
\hline HK-23-29-104 & 09/18/01 & $<.7$ & $<.7$ & $<7$ & $<1$ & $<.04$ & $<.3$ & $<.2$ & $<.1$ & $<.06$ & $<.04$ & $<.04$ & $<.03$ \\
\hline HS-28-09-808 & 08/16/01 & $<.7$ & $<.7$ & $<7$ & $<1$ & $<.04$ & $<.3$ & $<.2$ & $<.1$ & $<.06$ & $<.04$ & $<.04$ & $<.03$ \\
\hline HS-28-27-411 & 08/15/01 & $<.7$ & $<.7$ & $<7$ & $<1$ & $<.04$ & $<.3$ & $<.2$ & $<.1$ & $<.06$ & $<.04$ & $<.04$ & $<.03$ \\
\hline HT-10-13-345 & 08/21/01 & $<.7$ & $<.7$ & $<7$ & $<1$ & $<.04$ & $<.3$ & $<.2$ & $<.1$ & $<.06$ & $<.04$ & $<.04$ & $<.03$ \\
\hline HT-10-13-640 & 09/21/01 & $<.7$ & $<.7$ & $<7$ & $<1$ & $<.04$ & $<.3$ & $<.2$ & $<.1$ & $<.06$ & $<.04$ & $<.04$ & $<.03$ \\
\hline JW-23-08-101 & 09/18/01 & $<.7$ & $<.7$ & $<7$ & $<1$ & $<.04$ & $<.3$ & $<.2$ & $<.1$ & $<.06$ & $<.04$ & $<.04$ & $<.03$ \\
\hline KD-26-24-203 & 08/13/01 & $<.7$ & $<.7$ & $<7$ & $<1$ & $<.04$ & $<.3$ & $<.2$ & $<.1$ & $<.06$ & $<.04$ & $<.04$ & $<.03$ \\
\hline KD-27-01-807 & 08/12/01 & $<.7$ & $<.7$ & $<7$ & $<1$ & $<.04$ & $<.3$ & $<.2$ & $<.1$ & $<.06$ & $<.04$ & $<.04$ & $<.03$ \\
\hline KD-27-19-518 & 08/13/01 & $<.7$ & $<.7$ & $<7$ & $<1$ & $<.04$ & $<.3$ & $<.2$ & $<.1$ & $<.06$ & $<.04$ & $<.04$ & $<.03$ \\
\hline KD-27-30-103 & 08/14/01 & $<.7$ & $<.7$ & $<7$ & $<1$ & $<.04$ & $<.3$ & $<.2$ & $<.1$ & $<.06$ & $<.04$ & $<.04$ & $<.03$ \\
\hline KY-11-43-805 & 08/25/01 & $<.7$ & $<.7$ & $<7$ & $<1$ & $<.04$ & $<.3$ & $<.2$ & $<.1$ & $<.06$ & $<.04$ & $<.04$ & $<.03$ \\
\hline KY-11-49-207 & 09/20/01 & $<.7$ & $<.7$ & $<7$ & $<1$ & $<.04$ & $<.3$ & $<.2$ & $<.1$ & $<.06$ & $<.04$ & $<.04$ & $<.03$ \\
\hline KY-23-03-904 & 09/19/01 & $<.7$ & $<.7$ & $<7$ & $<1$ & $<.04$ & $<.3$ & $<.2$ & $<.1$ & $<.06$ & $<.04$ & $<.04$ & $<.03$ \\
\hline KY-23-10-304 & 09/19/01 & $<.7$ & $<.7$ & $<7$ & $<1$ & $<.04$ & $<.3$ & $<.2$ & $<.1$ & $<.06$ & $<.04$ & $<.04$ & $<.03$ \\
\hline PB-28-37-307 & 09/26/01 & $<.7$ & $<.7$ & $<7$ & $<1$ & $<.04$ & $<.3$ & $<.2$ & $<.1$ & $<.06$ & $<.04$ & $<.04$ & $<.03$ \\
\hline RU-10-52-107 & 09/22/01 & $<.7$ & $<.7$ & $<7$ & $<1$ & $<.04$ & $<.3$ & $<.2$ & $<.1$ & $<.06$ & $<.04$ & $<.04$ & $<.03$ \\
\hline RU-10-55-407 & 08/26/01 & $<.7$ & $<.7$ & $<7$ & $<1$ & $<.04$ & $<.3$ & $<.2$ & $<.1$ & $<.06$ & $<.04$ & $<.04$ & $<.03$ \\
\hline SP-23-17-712 & 08/10/01 & $<.7$ & $<.7$ & $<7$ & $<1$ & $<.04$ & $<.3$ & $<.2$ & $<.1$ & $<.06$ & $<.04$ & $<.04$ & $<.03$ \\
\hline SP-23-25-904 & 08/17/01 & $<.7$ & $<.7$ & $<7$ & $<1$ & $<.04$ & $<.3$ & $<.2$ & $<.1$ & $<.06$ & $<.04$ & $<.04$ & $<.03$ \\
\hline SR-23-41-502 & 08/17/01 & $<.7$ & $<.7$ & $<7$ & $<1$ & $<.04$ & $<.3$ & $<.2$ & $<.1$ & $<.06$ & $<.04$ & $<.04$ & $<.03$ \\
\hline SY-27-48-611 & 08/14/01 & $<.7$ & $<.7$ & $<7$ & $<1$ & $<.04$ & $<.3$ & $<.2$ & $<.1$ & $<.06$ & $<.04$ & $<.04$ & $<.03$ \\
\hline SY-28-42-707 & 08/15/01 & $<.7$ & $<.7$ & $<7$ & $<1$ & $<.04$ & $<.3$ & $<.2$ & $<.1$ & $<.06$ & $<.04$ & $<.04$ & $<.03$ \\
\hline SY-28-58-204 & 09/26/01 & $<.7$ & $<.7$ & $<7$ & $<1$ & $<.04$ & $<.3$ & $<.2$ & $<.1$ & $<.06$ & $<.04$ & $<.04$ & $<.03$ \\
\hline $\mathrm{UH}-07-53-228$ & 08/21/01 & $<.7$ & $<.7$ & $<7$ & $<1$ & $<.04$ & $<.3$ & $<.2$ & $<.1$ & $<.06$ & $<.04$ & $<.04$ & $<.03$ \\
\hline UR-10-19-506 & $08 / 22 / 01$ & $<.7$ & $<.7$ & $<7$ & $<1$ & $<.04$ & $<.3$ & $<.2$ & $<.1$ & $<.06$ & $<.04$ & $<.04$ & $<.03$ \\
\hline UR-10-42-204 & 08/22/01 & $<.7$ & $<.7$ & $<7$ & $<1$ & $<.04$ & $<.3$ & $<.2$ & $<.1$ & $<.06$ & $<.04$ & $<.04$ & $<.03$ \\
\hline UY-06-57-824 & 08/20/01 & $<.7$ & $<.7$ & $<7$ & $<1$ & $<.04$ & $<.3$ & $<.2$ & $<.1$ & $<.06$ & $<.04$ & $<.04$ & $<.03$ \\
\hline UY-10-07-631 & 08/20/01 & $<.7$ & $<.7$ & $<7$ & $<1$ & $<.04$ & $<.3$ & $<.2$ & $<.1$ & $<.06$ & $<.04$ & $<.04$ & $<.03$ \\
\hline XT-11-44-605 & 08/25/01 & $<.7$ & $<.7$ & $<7$ & $<1$ & $<.04$ & $<.3$ & $<.2$ & $<.1$ & $<.06$ & $<.04$ & $<.04$ & $<.03$ \\
\hline XY-24-45-502 & 08/07/01 & $<.7$ & $<.7$ & $<7$ & $<1$ & $<.04$ & $<.3$ & $<.2$ & $<.1$ & $<.06$ & $<.04$ & $<.04$ & $<.03$ \\
\hline$X Y-24-47-207$ & 08/16/01 & $<.7$ & $<.7$ & $<7$ & $<1$ & $<.04$ & $<.3$ & $<.2$ & $<.1$ & $<.06$ & $<.04$ & $<.04$ & $<.03$ \\
\hline XY-24-62-801 & 08/08/01 & $<.7$ & $<.7$ & $<7$ & $<1$ & $<.04$ & $<.3$ & $<.2$ & $<.1$ & $<.06$ & $<.04$ & $<.04$ & $<.03$ \\
\hline ZT-24-43-202 & 08/12/01 & $<.7$ & $<.7$ & $<7$ & $<1$ & $<.04$ & $<.3$ & $<.2$ & $<.1$ & $<.06$ & $<.04$ & $<.04$ & $<.03$ \\
\hline ZT-24-50-602 & 08/11/01 & $<.7$ & $<.7$ & $<7$ & $<1$ & $<.04$ & $<.3$ & $<.2$ & $<.1$ & $<.06$ & $<.04$ & $<.04$ & $<.03$ \\
\hline ZT-25-40-804 & 09/25/01 & -- & -- & -- & -- & -- & -- & -- & -- & -- & -- & -- & -- \\
\hline
\end{tabular}


Appendix 7. Volatile organic compound concentrations in water sampled from primarily domestic wells screened in the southern High Plains aquifer, Texas and New Mexico, 2001—Continued

\begin{tabular}{|c|c|c|c|c|c|c|c|c|c|c|c|}
\hline $\begin{array}{c}\text { State } \\
\text { well no. }\end{array}$ & $\begin{array}{l}\text { Benzene, } \\
\text { ethyl- }\end{array}$ & $\begin{array}{l}\text { Benzene, } \\
\text { isopropyl- }\end{array}$ & $\begin{array}{l}\text { Benzene, } \\
\text { n-propyl- }\end{array}$ & $\begin{array}{l}\text { Benzene, } \\
\text { m-dichloro- }\end{array}$ & $\begin{array}{l}\text { Benzene, } \\
\text { o-dichloro- }\end{array}$ & $\begin{array}{l}\text { Benzene, } \\
\text { p-dichloro- }\end{array}$ & $\begin{array}{c}\text { Benzene, } \\
\text { n-butyl- }\end{array}$ & $\begin{array}{l}\text { Benzene, } \\
\text { sec-butyl- }\end{array}$ & $\begin{array}{l}\text { Benzene, } \\
\text { tert-butyl- }\end{array}$ & $\begin{array}{c}\text { Benzene, } \\
\text { 1,2,3,4- } \\
\text { tetra- } \\
\text { methyl- }\end{array}$ & $\begin{array}{c}\text { Benzene, } \\
\text { 1,2,3,5- } \\
\text { tetra- } \\
\text { methyl- }\end{array}$ \\
\hline & & Cumene & & $\begin{array}{c}\text { Benzene, } \\
\text { 1,3-dichloro- }\end{array}$ & $\begin{array}{c}\text { Benzene, } \\
\text { 1,2-dichloro- }\end{array}$ & $\begin{array}{c}\text { Benzene, } \\
\text { 1,4-dichloro- }\end{array}$ & & & & Prehnitene & $\begin{array}{l}\text { Iso- } \\
\text { durene }\end{array}$ \\
\hline NM03N.36E.28.411 & $<0.03$ & $<0.03$ & $<0.04$ & $<0.03$ & $<0.03$ & $<0.05$ & $<0.2$ & $<0.03$ & $<0.06$ & $<0.2$ & $<0.2$ \\
\hline NM05N.34E.36.244 & $<.03$ & $<.03$ & $<.04$ & $<.03$ & $<.03$ & $<.05$ & $<.2$ & $<.03$ & $<.06$ & $<.2$ & $<.2$ \\
\hline NM13S.38E.14.3333A & $<.03$ & $<.03$ & $<.04$ & $<.03$ & $<.03$ & $<.05$ & $<.2$ & $<.03$ & $<.06$ & $<.2$ & $<.2$ \\
\hline NM15S.38E.14.211 & $<.03$ & $<.03$ & $<.04$ & $<.03$ & $<.03$ & $<.05$ & $<.2$ & $<.03$ & $<.06$ & $<.2$ & $<.2$ \\
\hline NM01N.36E.21.233 & $<.03$ & $<.03$ & $<.04$ & $<.03$ & $<.03$ & $<.05$ & $<.2$ & $<.03$ & $<.06$ & $<.2$ & $<.2$ \\
\hline NM02S.36E.17.231 & $<.03$ & $<.03$ & $<.04$ & $<.03$ & $<.03$ & $<.05$ & $<.2$ & $<.03$ & $<.06$ & $<.2$ & $<.2$ \\
\hline $\mathrm{AB}-27-29-905$ & $<.03$ & $<.03$ & $<.04$ & $<.03$ & $<.03$ & $<.05$ & $<.2$ & $<.03$ & $<.06$ & $<.2$ & $<.2$ \\
\hline AR-25-08-603 & $<.03$ & $<.03$ & $<.04$ & $<.03$ & $<.03$ & $<.05$ & $<.2$ & $<.03$ & $<.06$ & $<.2$ & $<.2$ \\
\hline BL-11-38-925 & $<.03$ & $<.03$ & $<.04$ & $<.03$ & $<.03$ & $<.05$ & $<.2$ & $<.03$ & $<.06$ & $<.2$ & $<.2$ \\
\hline DD-10-30-803 & $<.03$ & $<.03$ & $<.04$ & $<.03$ & $<.03$ & $<.05$ & $<.2$ & $<.03$ & $<.06$ & $<.2$ & $<.2$ \\
\hline DP-24-19-405 & $<.03$ & $<.03$ & $<.04$ & $<.03$ & $<.03$ & $<.05$ & $<.2$ & $<.03$ & $<.06$ & $<.2$ & $<.2$ \\
\hline DP-24-20-705 & $<.03$ & $<.03$ & $<.04$ & $<.03$ & $<.03$ & $<.05$ & $<.2$ & $<.03$ & $<.06$ & $<.2$ & $<.2$ \\
\hline HK-23-14-404 & $<.03$ & $<.03$ & $<.04$ & $<.03$ & $<.03$ & $<.05$ & $<.2$ & $<.03$ & $<.06$ & $<.2$ & $<.2$ \\
\hline HK-23-29-104 & $<.03$ & $<.03$ & $<.04$ & $<.03$ & $<.03$ & $<.05$ & $<.2$ & $<.03$ & $<.06$ & $<.2$ & $<.2$ \\
\hline HS-28-09-808 & $<.03$ & $<.03$ & $<.04$ & $<.03$ & $<.03$ & $<.05$ & $<.2$ & $<.03$ & $<.06$ & $<.2$ & $<.2$ \\
\hline HS-28-27-411 & $<.03$ & $<.03$ & $<.04$ & $<.03$ & $<.03$ & $<.05$ & $<.2$ & $<.03$ & $<.06$ & $<.2$ & $<.2$ \\
\hline HT-10-13-345 & $<.03$ & $<.03$ & $<.04$ & $<.03$ & $<.03$ & $<.05$ & $<.2$ & $<.03$ & $<.06$ & $<.2$ & $<.2$ \\
\hline HT-10-13-640 & $<.03$ & $<.03$ & $<.04$ & $<.03$ & $<.03$ & $<.05$ & $<.2$ & $<.03$ & $<.06$ & $<.2$ & $<.2$ \\
\hline JW-23-08-101 & $<.03$ & $<.03$ & $<.04$ & $<.03$ & $<.03$ & $<.05$ & $<.2$ & $<.03$ & $<.06$ & $<.2$ & $<.2$ \\
\hline KD-26-24-203 & $<.03$ & $<.03$ & $<.04$ & $<.03$ & $<.03$ & $<.05$ & $<.2$ & $<.03$ & $<.06$ & $<.2$ & $<.2$ \\
\hline KD-27-01-807 & $<.03$ & $<.03$ & $<.04$ & $<.03$ & $<.03$ & $<.05$ & $<.2$ & $<.03$ & $<.06$ & $<.2$ & $<.2$ \\
\hline KD-27-19-518 & $<.03$ & $<.03$ & $<.04$ & $<.03$ & $<.03$ & $<.05$ & $<.2$ & $<.03$ & $<.06$ & $<.2$ & $<.2$ \\
\hline KD-27-30-103 & $<.03$ & $<.03$ & $<.04$ & $<.03$ & $<.03$ & $<.05$ & $<.2$ & $<.03$ & $<.06$ & $<.2$ & $<.2$ \\
\hline $\mathrm{KY}-11-43-805$ & $<.03$ & $<.03$ & $<.04$ & $<.03$ & $<.03$ & $<.05$ & $<.2$ & $<.03$ & $<.06$ & $<.2$ & $<.2$ \\
\hline KY-11-49-207 & $<.03$ & $<.03$ & $<.04$ & $<.03$ & $<.03$ & $<.05$ & $<.2$ & $<.03$ & $<.06$ & $<.2$ & $<.2$ \\
\hline KY-23-03-904 & $<.03$ & $<.03$ & $<.04$ & $<.03$ & $<.03$ & $<.05$ & $<.2$ & $<.03$ & $<.06$ & $<.2$ & $<.2$ \\
\hline $\mathrm{KY}-23-10-304$ & $<.03$ & $<.03$ & $<.04$ & $<.03$ & $<.03$ & $<.05$ & $<.2$ & $<.03$ & $<.06$ & $<.2$ & $<.2$ \\
\hline PB-28-37-307 & $<.03$ & $<.03$ & $<.04$ & $<.03$ & $<.03$ & $<.05$ & $<.2$ & $<.03$ & $<.06$ & $<.2$ & $<.2$ \\
\hline RU-10-52-107 & $<.03$ & $<.03$ & $<.04$ & $<.03$ & $<.03$ & $<.05$ & $<.2$ & $<.03$ & $<.06$ & $<.2$ & $<.2$ \\
\hline RU-10-55-407 & $<.03$ & $<.03$ & $<.04$ & $<.03$ & $<.03$ & $<.05$ & $<.2$ & $<.03$ & $<.06$ & $<.2$ & $<.2$ \\
\hline SP-23-17-712 & $<.03$ & $<.03$ & $<.04$ & $<.03$ & $<.03$ & $<.05$ & $<.2$ & $<.03$ & $<.06$ & $<.2$ & $<.2$ \\
\hline $\mathrm{SP}-23-25-904$ & $<.03$ & $<.03$ & $<.04$ & $<.03$ & $<.03$ & $<.05$ & $<.2$ & $<.03$ & $<.06$ & $<.2$ & $<.2$ \\
\hline SR-23-41-502 & $<.03$ & $<.03$ & $<.04$ & $<.03$ & $<.03$ & $<.05$ & $<.2$ & $<.03$ & $<.06$ & $<.2$ & $<.2$ \\
\hline$S Y-27-48-611$ & $<.03$ & $<.03$ & $<.04$ & $<.03$ & $<.03$ & $<.05$ & $<.2$ & $<.03$ & $<.06$ & $<.2$ & $<.2$ \\
\hline SY-28-42-707 & $<.03$ & $<.03$ & $<.04$ & $<.03$ & $<.03$ & $<.05$ & $<.2$ & $<.03$ & $<.06$ & $<.2$ & $<.2$ \\
\hline SY-28-58-204 & $<.03$ & $<.03$ & $<.04$ & $<.03$ & $<.03$ & $<.05$ & $<.2$ & $<.03$ & $<.06$ & $<.2$ & $<.2$ \\
\hline UH-07-53-228 & $<.03$ & $<.03$ & $<.04$ & $<.03$ & $<.03$ & $<.05$ & $<.2$ & $<.03$ & $<.06$ & $<.2$ & $<.2$ \\
\hline UR-10-19-506 & $<.03$ & $<.03$ & $<.04$ & $<.03$ & $<.03$ & $<.05$ & $<.2$ & $<.03$ & $<.06$ & $<.2$ & $<.2$ \\
\hline UR-10-42-204 & $<.03$ & $<.03$ & $<.04$ & $<.03$ & $<.03$ & $<.05$ & $<.2$ & $<.03$ & $<.06$ & $<.2$ & $<.2$ \\
\hline $\mathrm{UY}-06-57-824$ & $<.03$ & $<.03$ & $<.04$ & $<.03$ & $<.03$ & $<.05$ & $<.2$ & $<.03$ & $<.06$ & $<.2$ & $<.2$ \\
\hline UY-10-07-631 & $<.03$ & $<.03$ & $<.04$ & $<.03$ & $<.03$ & $<.05$ & $<.2$ & $<.03$ & $<.06$ & $<.2$ & $<.2$ \\
\hline XT-11-44-605 & $<.03$ & $<.03$ & $<.04$ & $<.03$ & $<.03$ & $<.05$ & $<.2$ & $<.03$ & $<.06$ & $<.2$ & $<.2$ \\
\hline$X Y-24-45-502$ & $<.03$ & $<.03$ & $<.04$ & $<.03$ & $<.03$ & $<.05$ & $<.2$ & $<.03$ & $<.06$ & $<.2$ & $<.2$ \\
\hline$X Y-24-47-207$ & $<.03$ & $<.03$ & $<.04$ & $<.03$ & $<.03$ & $<.05$ & $<.2$ & $<.03$ & $<.06$ & $<.2$ & $<.2$ \\
\hline$X Y-24-62-801$ & $<.03$ & $<.03$ & $<.04$ & $<.03$ & $<.03$ & $<.05$ & $<.2$ & $<.03$ & $<.06$ & $<.2$ & $<.2$ \\
\hline ZT-24-43-202 & $<.03$ & $<.03$ & $<.04$ & $<.03$ & $<.03$ & $<.05$ & $<.2$ & $<.03$ & $<.06$ & $<.2$ & $<.2$ \\
\hline ZT-24-50-602 & $<.03$ & $<.03$ & $<.04$ & $<.03$ & $<.03$ & $<.05$ & $<.2$ & $<.03$ & $<.06$ & $<.2$ & $<.2$ \\
\hline $\mathrm{ZT}-25-40-804$ & -- & -- & -- & -- & -- & -- & -- & -- & -- & -- & -- \\
\hline
\end{tabular}


Appendix 7. Volatile organic compound concentrations in water sampled from primarily domestic wells screened in the southern High Plains aquifer, Texas and New Mexico, 2001—Continued

\begin{tabular}{|c|c|c|c|c|c|c|c|c|c|c|}
\hline $\begin{array}{c}\text { State } \\
\text { well no. }\end{array}$ & $\begin{array}{l}\text { Bromo- } \\
\text { ethene }\end{array}$ & $\begin{array}{l}\text { Butadiene, } \\
\text { hexa- } \\
\text { chloro- }\end{array}$ & $\begin{array}{c}\text { Carbon } \\
\text { disulfide }\end{array}$ & $\begin{array}{l}\text { Ethane, 1,2- } \\
\text { dibromo- }\end{array}$ & $\begin{array}{l}\text { Ethane, } \\
\text { chloro- }\end{array}$ & $\begin{array}{c}\text { Ethane, } \\
\text { 1,1-dichloro- }\end{array}$ & $\begin{array}{l}\text { Ethane, 1,2- } \\
\text { dichloro- }\end{array}$ & $\begin{array}{c}\text { Ethane, 1,1,1- } \\
\text { trichloro- }\end{array}$ & $\begin{array}{c}\text { Ethane, } \\
1,1,2- \\
\text { trichloro- }\end{array}$ & $\begin{array}{c}\text { Ethane, } \\
1,1,1,2- \\
\text { tetrachloro- }\end{array}$ \\
\hline & & & & EDB & $\begin{array}{l}\text { Ethyl } \\
\text { chloride }\end{array}$ & $\begin{array}{l}\text { Ethylidene } \\
\text { chloride }\end{array}$ & $\begin{array}{l}\text { Ethylene } \\
\text { dichloride }\end{array}$ & & $\begin{array}{c}\text { Vinyl } \\
\text { trichloride }\end{array}$ & \\
\hline NM03N.36E.28.411 & $<0.1$ & $<0.1$ & $<0.07$ & $<0.04$ & $<0.1$ & $<0.04$ & $<0.1$ & $<0.03$ & $<0.06$ & $<0.03$ \\
\hline NM05N.34E.36.244 & $<.1$ & $<.1$ & $<.07$ & $<.04$ & $<.1$ & $<.04$ & $<.1$ & $<.03$ & $<.06$ & $<.03$ \\
\hline NM13S.38E.14.3333A & $<.1$ & $<.1$ & $<.07$ & $<.04$ & $<.1$ & $<.04$ & $<.1$ & $<.03$ & $<.06$ & $<.03$ \\
\hline NM15S.38E.14.211 & $<.1$ & $<.1$ & $<.07$ & $<.04$ & $<.1$ & $<.04$ & $<.1$ & $<.03$ & $<.06$ & $<.03$ \\
\hline NM01N.36E.21.233 & $<.1$ & $<.1$ & $<.07$ & $<.04$ & $<.1$ & $<.04$ & $<.1$ & $<.03$ & $<.06$ & $<.03$ \\
\hline NM02S.36E.17.231 & $<.1$ & $<.1$ & $<.07$ & $<.04$ & $<.1$ & $<.04$ & $<.1$ & $<.03$ & $<.06$ & $<.03$ \\
\hline AB-27-29-905 & $<.1$ & $<.1$ & $<.07$ & $<.04$ & $<.1$ & $<.04$ & $<.1$ & $<.03$ & $<.06$ & $<.03$ \\
\hline AR-25-08-603 & $<.1$ & $<.1$ & $<.07$ & $<.04$ & $<.1$ & $<.04$ & $<.1$ & $<.03$ & $<.06$ & $<.03$ \\
\hline BL-11-38-925 & $<.1$ & $<.1$ & $<.07$ & $<.04$ & $<.1$ & $<.04$ & $<.1$ & $<.03$ & $<.06$ & $<.03$ \\
\hline DD-10-30-803 & $<.1$ & $<.1$ & $<.07$ & $<.04$ & $<.1$ & $<.04$ & $<.1$ & $<.03$ & $<.06$ & $<.03$ \\
\hline DP-24-19-405 & $<.1$ & $<.1$ & $<.07$ & $<.04$ & $<.1$ & $<.04$ & $<.1$ & $<.03$ & $<.06$ & $<.03$ \\
\hline DP-24-20-705 & $<.1$ & $<.1$ & $<.07$ & $<.04$ & $<.1$ & $<.04$ & $<.1$ & $<.03$ & $<.06$ & $<.03$ \\
\hline HK-23-14-404 & $<.1$ & $<.1$ & $<.07$ & $<.04$ & $<.1$ & $<.04$ & $<.1$ & $<.03$ & $<.06$ & $<.03$ \\
\hline HK-23-29-104 & $<.1$ & $<.1$ & $<.07$ & $<.04$ & $<.1$ & $<.04$ & $<.1$ & $<.03$ & $<.06$ & $<.03$ \\
\hline HS-28-09-808 & $<.1$ & $<.1$ & $<.07$ & $<.04$ & $<.1$ & $<.04$ & $<.1$ & $<.03$ & $<.06$ & $<.03$ \\
\hline HS-28-27-411 & $<.1$ & $<.1$ & $<.07$ & $<.04$ & $<.1$ & $<.04$ & $<.1$ & $<.03$ & $<.06$ & $<.03$ \\
\hline HT-10-13-345 & $<.1$ & $<.1$ & $<.07$ & $<.04$ & $<.1$ & $<.04$ & $<.1$ & $<.03$ & $<.06$ & $<.03$ \\
\hline HT-10-13-640 & $<.1$ & $<.1$ & $<.07$ & $<.04$ & $<.1$ & $<.04$ & $<.1$ & $<.03$ & $<.06$ & $<.03$ \\
\hline JW-23-08-101 & $<.1$ & $<.1$ & $<.07$ & $<.04$ & $<.1$ & $<.04$ & $<.1$ & $<.03$ & $<.06$ & $<.03$ \\
\hline KD-26-24-203 & $<.1$ & $<.1$ & $<.07$ & $<.04$ & $<.1$ & $<.04$ & $<.1$ & $<.03$ & $<.06$ & $<.03$ \\
\hline KD-27-01-807 & $<.1$ & $<.1$ & $<.07$ & $<.04$ & $<.1$ & $<.04$ & $<.1$ & $<.03$ & $<.06$ & $<.03$ \\
\hline KD-27-19-518 & $<.1$ & $<.1$ & $<.07$ & $<.04$ & $<.1$ & $<.04$ & $<.1$ & $<.03$ & $<.06$ & $<.03$ \\
\hline KD-27-30-103 & $<.1$ & $<.1$ & $<.07$ & $<.04$ & $<.1$ & $<.04$ & $<.1$ & $<.03$ & $<.06$ & $<.03$ \\
\hline KY-11-43-805 & $<.1$ & $<.1$ & $<.07$ & $<.04$ & $<.1$ & $<.04$ & $<.1$ & $<.03$ & $<.06$ & $<.03$ \\
\hline KY-11-49-207 & $<.1$ & $<.1$ & $<.07$ & $<.04$ & $<.1$ & $<.04$ & $<.1$ & $<.03$ & $<.06$ & $<.03$ \\
\hline KY-23-03-904 & $<.1$ & $<.1$ & $<.07$ & $<.04$ & $<.1$ & $<.04$ & $<.1$ & $<.03$ & $<.06$ & $<.03$ \\
\hline KY-23-10-304 & $<.1$ & $<.1$ & $<.07$ & $<.04$ & $<.1$ & $<.04$ & $<.1$ & $<.03$ & $<.06$ & $<.03$ \\
\hline PB-28-37-307 & $<.1$ & $<.1$ & $<.07$ & $<.04$ & $<.1$ & $<.04$ & $<.1$ & $<.03$ & $<.06$ & $<.03$ \\
\hline RU-10-52-107 & $<.1$ & $<.1$ & $<.07$ & $<.04$ & $<.1$ & $<.04$ & $<.1$ & $<.03$ & $<.06$ & $<.03$ \\
\hline RU-10-55-407 & $<.1$ & $<.1$ & $<.07$ & $<.04$ & $<.1$ & $<.04$ & $<.1$ & $<.03$ & $<.06$ & $<.03$ \\
\hline SP-23-17-712 & $<.1$ & $<.1$ & $<.07$ & $<.04$ & $<.1$ & $<.04$ & $<.1$ & $<.03$ & $<.06$ & $<.03$ \\
\hline SP-23-25-904 & $<.1$ & $<.1$ & $<.07$ & $<.04$ & $<.1$ & $<.04$ & $<.1$ & $<.03$ & $<.06$ & $<.03$ \\
\hline SR-23-41-502 & $<.1$ & $<.1$ & $<.07$ & $<.04$ & $<.1$ & $<.04$ & $<.1$ & $<.03$ & $<.06$ & $<.03$ \\
\hline SY-27-48-611 & $<.1$ & $<.1$ & $<.07$ & $<.04$ & $<.1$ & $<.04$ & $<.1$ & $<.03$ & $<.06$ & $<.03$ \\
\hline SY-28-42-707 & $<.1$ & $<.1$ & $<.07$ & $<.04$ & $<.1$ & $<.04$ & $<.1$ & $<.03$ & $<.06$ & $<.03$ \\
\hline SY-28-58-204 & $<.1$ & $<.1$ & $<.07$ & $<.04$ & $<.1$ & $<.04$ & $<.1$ & $<.03$ & $<.06$ & $<.03$ \\
\hline UH-07-53-228 & $<.1$ & $<.1$ & $<.07$ & $<.04$ & $<.1$ & $<.04$ & $<.1$ & $<.03$ & $<.06$ & $<.03$ \\
\hline UR-10-19-506 & $<.1$ & $<.1$ & $<.07$ & $<.04$ & $<.1$ & $<.04$ & $<.1$ & $<.03$ & $<.06$ & $<.03$ \\
\hline UR-10-42-204 & $<.1$ & $<.1$ & $<.07$ & $<.04$ & $<.1$ & $<.04$ & $<.1$ & $<.03$ & $<.06$ & $<.03$ \\
\hline UY-06-57-824 & $<.1$ & $<.1$ & $<.07$ & $<.04$ & $<.1$ & $<.04$ & $<.1$ & $<.03$ & $<.06$ & $<.03$ \\
\hline UY-10-07-631 & $<.1$ & $<.1$ & $<.07$ & $<.04$ & $<.1$ & $<.04$ & $<.1$ & $<.03$ & $<.06$ & $<.03$ \\
\hline XT-11-44-605 & $<.1$ & $<.1$ & $<.07$ & $<.04$ & $<.1$ & $<.04$ & $<.1$ & $<.03$ & $<.06$ & $<.03$ \\
\hline$X Y-24-45-502$ & $<.1$ & $<.1$ & $<.07$ & $<.04$ & $<.1$ & $<.04$ & $<.1$ & $<.03$ & $<.06$ & $<.03$ \\
\hline XY-24-47-207 & $<.1$ & $<.1$ & $<.07$ & $<.04$ & $<.1$ & $<.04$ & $<.1$ & $<.03$ & $<.06$ & $<.03$ \\
\hline$X Y-24-62-801$ & $<.1$ & $<.1$ & $<.07$ & $<.04$ & $<.1$ & $<.04$ & $<.1$ & $<.03$ & $<.06$ & $<.03$ \\
\hline ZT-24-43-202 & $<.1$ & $<.1$ & $<.07$ & $<.04$ & $<.1$ & $<.04$ & $<.1$ & $<.03$ & $<.06$ & $<.03$ \\
\hline ZT-24-50-602 & $<.1$ & $<.1$ & $<.07$ & $<.04$ & $<.1$ & $<.04$ & $<.1$ & $<.03$ & $<.06$ & $<.03$ \\
\hline ZT-25-40-804 & -- & -- & -- & -- & -- & -- & -- & -- & -- & -- \\
\hline
\end{tabular}


Appendix 7. Volatile organic compound concentrations in water sampled from primarily domestic wells screened in the southern High Plains aquifer, Texas and New Mexico, 2001—Continued

\begin{tabular}{|c|c|c|c|c|c|c|c|c|c|c|c|}
\hline $\begin{array}{c}\text { State } \\
\text { well no. }\end{array}$ & $\begin{array}{c}\text { Ethane, } \\
1,1,2,2- \\
\text { tetrachloro- }\end{array}$ & $\begin{array}{l}\text { Ethane, } \\
\text { hexa- } \\
\text { chloro- }\end{array}$ & $\begin{array}{c}\text { Ethane, 1,1,2- } \\
\text { trichloro- } \\
\text { 1,2,2-trifluoro- }\end{array}$ & $\begin{array}{l}\text { Ether, } \\
\text { diethyl- }\end{array}$ & $\begin{array}{l}\text { Ether, } \\
\text { diisopropyl- }\end{array}$ & $\begin{array}{c}\text { Ether, } \\
\text { methyl- } \\
\text { tert-butyl- }\end{array}$ & $\begin{array}{l}\text { Ether, } \\
\text { tert-butyl- } \\
\text { ethyl- }\end{array}$ & $\begin{array}{c}\text { Ether, } \\
\text { tert-pentyl- } \\
\text { methyl- }\end{array}$ & $\begin{array}{l}\text { Ethene, } \\
\text { chloro- }\end{array}$ & $\begin{array}{l}\text { Ethene, } \\
\text { 1,1- } \\
\text { dichloro- }\end{array}$ & $\begin{array}{l}\text { Ethene, } \\
\text { cis-1,2- } \\
\text { dichloro- }\end{array}$ \\
\hline & & & $\begin{array}{c}\text { Freon 113, } \\
\text { CFC 113 }\end{array}$ & & DIPE & MTBE & & & $\begin{array}{c}\text { Vinyl } \\
\text { chloride }\end{array}$ & $\begin{array}{l}\text { Vinylidene } \\
\text { chloride }\end{array}$ & \\
\hline NM03N.36E.28.411 & $<0.09$ & $<0.2$ & $<0.06$ & $<0.2$ & $<0.1$ & $<0.2$ & $<0.05$ & $<0.1$ & $<0.1$ & $<0.04$ & $<0.04$ \\
\hline NM05N.34E.36.244 & $<.09$ & $<.2$ & $<.06$ & $<.2$ & $<.1$ & $<.2$ & $<.05$ & $<.1$ & $<.1$ & $<.04$ & $<.04$ \\
\hline NM13S.38E.14.3333A & $<.09$ & $<.2$ & $<.06$ & $<.2$ & $<.1$ & $<.2$ & $<.05$ & $<.1$ & $<.1$ & $<.04$ & $<.04$ \\
\hline NM15S.38E.14.211 & $<.09$ & $<.2$ & $<.06$ & $<.2$ & $<.1$ & $<.2$ & $<.05$ & $<.1$ & $<.1$ & $<.04$ & $<.04$ \\
\hline NM01N.36E.21.233 & $<.09$ & $<.2$ & $<.06$ & $<.2$ & $<.1$ & $<.2$ & $<.05$ & $<.1$ & $<.1$ & $<.04$ & $<.04$ \\
\hline NM02S.36E.17.231 & $<.09$ & $<.2$ & $<.06$ & $<.2$ & $<.1$ & $<.2$ & $<.05$ & $<.1$ & $<.1$ & $<.04$ & $<.04$ \\
\hline AB-27-29-905 & $<.09$ & $<.2$ & $<.06$ & $<.2$ & $<.1$ & $<.2$ & $<.05$ & $<.1$ & $<.1$ & $<.04$ & $<.04$ \\
\hline AR-25-08-603 & $<.09$ & $<.2$ & $<.06$ & $<.2$ & $<.1$ & $<.2$ & $<.05$ & $<.1$ & $<.1$ & $<.04$ & $<.04$ \\
\hline BL-11-38-925 & $<.09$ & $<.2$ & $<.06$ & $<.2$ & $<.1$ & $<.2$ & $<.05$ & $<.1$ & $<.1$ & $<.04$ & $<.04$ \\
\hline DD-10-30-803 & $<.09$ & $<.2$ & $<.06$ & $<.2$ & $<.1$ & $<.2$ & $<.05$ & $<.1$ & $<.1$ & $<.04$ & $<.04$ \\
\hline DP-24-19-405 & $<.09$ & $<.2$ & $<.06$ & $<.2$ & $<.1$ & $<.2$ & $<.05$ & $<.1$ & $<.1$ & $<.04$ & $<.04$ \\
\hline DP-24-20-705 & $<.09$ & $<.2$ & $<.06$ & $<.2$ & $<.1$ & $<.2$ & $<.05$ & $<.1$ & $<.1$ & $<.04$ & $<.04$ \\
\hline HK-23-14-404 & $<.09$ & $<.2$ & $<.06$ & $<.2$ & $<.1$ & $<.2$ & $<.05$ & $<.1$ & $<.1$ & $<.04$ & $<.04$ \\
\hline HK-23-29-104 & $<.09$ & $<.2$ & $<.06$ & $<.2$ & $<.1$ & $<.2$ & $<.05$ & $<.1$ & $<.1$ & $<.04$ & $<.04$ \\
\hline HS-28-09-808 & $<.09$ & $<.2$ & $<.06$ & $<.2$ & $<.1$ & $<.2$ & $<.05$ & $<.1$ & $<.1$ & $<.04$ & $<.04$ \\
\hline HS-28-27-411 & $<.09$ & $<.2$ & $<.06$ & $<.2$ & $<.1$ & $<.2$ & $<.05$ & $<.1$ & $<.1$ & $<.04$ & $<.04$ \\
\hline HT-10-13-345 & $<.09$ & $<.2$ & $<.06$ & $<.2$ & $<.1$ & $<.2$ & $<.05$ & $<.1$ & $<.1$ & $<.04$ & $<.04$ \\
\hline HT-10-13-640 & $<.09$ & $<.2$ & $<.06$ & $<.2$ & $<.1$ & $<.2$ & $<.05$ & $<.1$ & $<.1$ & $<.04$ & $<.04$ \\
\hline JW-23-08-101 & $<.09$ & $<.2$ & $<.06$ & $<.2$ & $<.1$ & $<.2$ & $<.05$ & $<.1$ & $<.1$ & $<.04$ & $<.04$ \\
\hline KD-26-24-203 & $<.09$ & $<.2$ & $<.06$ & $<.2$ & $<.1$ & $<.2$ & $<.05$ & $<.1$ & $<.1$ & $<.04$ & $<.04$ \\
\hline KD-27-01-807 & $<.09$ & $<.2$ & $<.06$ & $<.2$ & $<.1$ & $<.2$ & $<.05$ & $<.1$ & $<.1$ & $<.04$ & $<.04$ \\
\hline KD-27-19-518 & $<.09$ & $<.2$ & $<.06$ & $<.2$ & $<.1$ & $<.2$ & $<.05$ & $<.1$ & $<.1$ & $<.04$ & $<.04$ \\
\hline KD-27-30-103 & $<.09$ & $<.2$ & $<.06$ & $<.2$ & $<.1$ & $<.2$ & $<.05$ & $<.1$ & $<.1$ & $<.04$ & $<.04$ \\
\hline KY-11-43-805 & $<.09$ & $<.2$ & $<.06$ & $<.2$ & $<.1$ & $<.2$ & $<.05$ & $<.1$ & $<.1$ & $<.04$ & $<.04$ \\
\hline KY-11-49-207 & $<.09$ & $<.2$ & $<.06$ & $<.2$ & $<.1$ & $<.2$ & $<.05$ & $<.1$ & $<.1$ & $<.04$ & $<.04$ \\
\hline KY-23-03-904 & $<.09$ & $<.2$ & $<.06$ & $<.2$ & $<.1$ & $<.2$ & $<.05$ & $<.1$ & $<.1$ & $<.04$ & $<.04$ \\
\hline KY-23-10-304 & $<.09$ & $<.2$ & $<.06$ & $<.2$ & $<.1$ & $<.2$ & $<.05$ & $<.1$ & $<.1$ & $<.04$ & $<.04$ \\
\hline PB-28-37-307 & $<.09$ & $<.2$ & $<.06$ & $<.2$ & $<.1$ & $<.2$ & $<.05$ & $<.1$ & $<.1$ & $<.04$ & $<.04$ \\
\hline RU-10-52-107 & $<.09$ & $<.2$ & $<.06$ & $<.2$ & $<.1$ & $<.2$ & $<.05$ & $<.1$ & $<.1$ & $<.04$ & $<.04$ \\
\hline RU-10-55-407 & $<.09$ & $<.2$ & $<.06$ & $<.2$ & $<.1$ & $<.2$ & $<.05$ & $<.1$ & $<.1$ & $<.04$ & $<.04$ \\
\hline SP-23-17-712 & $<.09$ & $<.2$ & $<.06$ & $<.2$ & $<.1$ & $<.2$ & $<.05$ & $<.1$ & $<.1$ & $<.04$ & $<.04$ \\
\hline SP-23-25-904 & $<.09$ & $<.2$ & $<.06$ & $<.2$ & $<.1$ & $<.2$ & $<.05$ & $<.1$ & $<.1$ & $<.04$ & $<.04$ \\
\hline SR-23-41-502 & $<.09$ & $<.2$ & $<.06$ & $<.2$ & $<.1$ & $<.2$ & $<.05$ & $<.1$ & $<.1$ & $<.04$ & $<.04$ \\
\hline SY-27-48-611 & $<.09$ & $<.2$ & $<.06$ & $<.2$ & $<.1$ & $<.2$ & $<.05$ & $<.1$ & $<.1$ & $<.04$ & $<.04$ \\
\hline SY-28-42-707 & $<.09$ & $<.2$ & $<.06$ & $<.2$ & $<.1$ & $<.2$ & $<.05$ & $<.1$ & $<.1$ & $<.04$ & $<.04$ \\
\hline SY-28-58-204 & $<.09$ & $<.2$ & $<.06$ & $<.2$ & $<.1$ & $<.2$ & $<.05$ & $<.1$ & $<.1$ & $<.04$ & $<.04$ \\
\hline UH-07-53-228 & $<.09$ & $<.2$ & $<.06$ & $<.2$ & $<.1$ & $<.2$ & $<.05$ & $<.1$ & $<.1$ & $<.04$ & $<.04$ \\
\hline UR-10-19-506 & $<.09$ & $<.2$ & $<.06$ & $<.2$ & $<.1$ & $<.2$ & $<.05$ & $<.1$ & $<.1$ & $<.04$ & $<.04$ \\
\hline UR-10-42-204 & $<.09$ & $<.2$ & $<.06$ & $<.2$ & $<.1$ & $<.2$ & $<.05$ & $<.1$ & $<.1$ & $<.04$ & $<.04$ \\
\hline UY-06-57-824 & $<.09$ & $<.2$ & $<.06$ & $<.2$ & $<.1$ & $<.2$ & $<.05$ & $<.1$ & $<.1$ & $<.04$ & $<.04$ \\
\hline UY-10-07-631 & $<.09$ & $<.2$ & $<.06$ & $<.2$ & $<.1$ & $<.2$ & $<.05$ & $<.1$ & $<.1$ & $<.04$ & $<.04$ \\
\hline XT-11-44-605 & $<.09$ & $<.2$ & $<.06$ & $<.2$ & $<.1$ & $<.2$ & $<.05$ & $<.1$ & $<.1$ & $<.04$ & $<.04$ \\
\hline$X Y-24-45-502$ & $<.09$ & $<.2$ & $<.06$ & $<.2$ & $<.1$ & $<.2$ & $<.05$ & $<.1$ & $<.1$ & $<.04$ & $<.04$ \\
\hline$X Y-24-47-207$ & $<.09$ & $<.2$ & $<.06$ & $<.2$ & $<.1$ & $<.2$ & $<.05$ & $<.1$ & $<.1$ & $<.04$ & $<.04$ \\
\hline $\mathrm{XY}-24-62-801$ & $<.09$ & $<.2$ & $<.06$ & $<.2$ & $<.1$ & $<.2$ & $<.05$ & $<.1$ & $<.1$ & $<.04$ & $<.04$ \\
\hline ZT-24-43-202 & $<.09$ & $<.2$ & $<.06$ & $<.2$ & $<.1$ & $<.2$ & $<.05$ & $<.1$ & $<.1$ & $<.04$ & $<.04$ \\
\hline ZT-24-50-602 & $<.09$ & $<.2$ & $<.06$ & $<.2$ & $<.1$ & $<.2$ & $<.05$ & $<.1$ & $<.1$ & $<.04$ & $<.04$ \\
\hline ZT-25-40-804 & -- & -- & -- & -- & -- & -- & -- & -- & -- & -- & -- \\
\hline
\end{tabular}


Appendix 7. Volatile organic compound concentrations in water sampled from primarily domestic wells screened in the southern High Plains aquifer, Texas and New Mexico, 2001—Continued

\begin{tabular}{|c|c|c|c|c|c|c|c|c|c|c|c|c|c|}
\hline $\begin{array}{c}\text { State } \\
\text { well no. }\end{array}$ & $\begin{array}{l}\text { Ethene, } \\
\text { trans-1,2- } \\
\text { dichloro- }\end{array}$ & $\begin{array}{l}\text { Ethene, } \\
\text { trichloro- }\end{array}$ & $\begin{array}{c}\text { Ethene, } \\
\text { tetrachloro- }\end{array}$ & $\begin{array}{c}\text { Furan, } \\
\text { tetrahydro- }\end{array}$ & $\begin{array}{l}\text { Ketone, } \\
\text { methyl- } \\
\text { ethyl- }\end{array}$ & $\begin{array}{l}\text { Ketone, } \\
\text { methyl- } \\
\text { isobutyl- }\end{array}$ & $\begin{array}{l}\text { Methyl- } \\
\text { acrylate }\end{array}$ & $\begin{array}{l}\text { Meth- } \\
\text { acrylate, } \\
\text { ethyl- }\end{array}$ & $\begin{array}{c}\text { Meth- } \\
\text { acrylate, } \\
\text { methyl- }\end{array}$ & $\begin{array}{l}\text { Meth- } \\
\text { acrylo- } \\
\text { nitrile }\end{array}$ & $\begin{array}{c}\text { Methane, } \\
\text { bromo- }\end{array}$ & $\begin{array}{l}\text { Methane, } \\
\text { dibromo- }\end{array}$ & $\begin{array}{l}\text { Methane, } \\
\text { tribromo- }\end{array}$ \\
\hline & & TCE & $\begin{array}{c}\text { Perchloro- } \\
\text { ethylene, PCE }\end{array}$ & & MEK & MIBK & & & & & $\begin{array}{c}\text { Methyl } \\
\text { bromide }\end{array}$ & $\begin{array}{c}\text { Methylene } \\
\text { bromide }\end{array}$ & $\begin{array}{c}\text { Bromo- } \\
\text { form }\end{array}$ \\
\hline NM03N.36E.28.411 & $<0.03$ & $<0.04$ & $<0.1$ & $<2$ & $<2$ & $<0.4$ & $<1$ & $<0.2$ & $<0.3$ & $<0.6$ & $<0.3$ & $<0.05$ & $<0.06$ \\
\hline NM05N.34E.36.244 & $<.03$ & $<.04$ & $<.1$ & $<2$ & $<2$ & $<.4$ & $<1$ & $<.2$ & $<.3$ & $<.6$ & $<.3$ & $<.05$ & $<.06$ \\
\hline NM13S.38E.14.3333A & $<.03$ & $<.04$ & $<.1$ & $<2$ & $<2$ & $<.4$ & $<1$ & $<.2$ & $<.3$ & $<.6$ & $<.3$ & $<.05$ & $<.06$ \\
\hline NM15S.38E.14.211 & $<.03$ & $<.04$ & $<.1$ & $<2$ & $<2$ & $<.4$ & $<1$ & $<.2$ & $<.3$ & $<.6$ & $<.3$ & $<.05$ & $<.06$ \\
\hline NM01N.36E.21.233 & $<.03$ & $<.04$ & $<.1$ & $<2$ & $<2$ & $<.4$ & $<1$ & $<.2$ & $<.3$ & $<.6$ & $<.3$ & $<.05$ & $<.06$ \\
\hline NM02S.36E.17.231 & $<.03$ & $<.04$ & $<.1$ & $<2$ & $<2$ & $<.4$ & $<1$ & $<.2$ & $<.3$ & $<.6$ & $<.3$ & $<.05$ & $<.06$ \\
\hline AB-27-29-905 & $<.03$ & $<.04$ & $<.1$ & $<2$ & $<2$ & $<.4$ & $<1$ & $<.2$ & $<.3$ & $<.6$ & $<.3$ & $<.05$ & $<.06$ \\
\hline AR-25-08-603 & $<.03$ & $<.04$ & $<.1$ & $<2$ & $<2$ & $<.4$ & $<1$ & $<.2$ & $<.3$ & $<.6$ & $<.3$ & $<.05$ & $<.06$ \\
\hline BL-11-38-925 & $<.03$ & $<.04$ & $<.1$ & $<2$ & $<2$ & $<.4$ & $<1$ & $<.2$ & $<.3$ & $<.6$ & $<.3$ & $<.05$ & $<.06$ \\
\hline DD-10-30-803 & $<.03$ & $<.04$ & $<.1$ & $<2$ & $<2$ & $<.4$ & $<1$ & $<.2$ & $<.3$ & $<.6$ & $<.3$ & $<.05$ & $<.06$ \\
\hline DP-24-19-405 & $<.03$ & $<.04$ & $<.1$ & $<2$ & $<2$ & $<.4$ & $<1$ & $<.2$ & $<.3$ & $<.6$ & $<.3$ & $<.05$ & $<.06$ \\
\hline DP-24-20-705 & $<.03$ & $<.04$ & $<.1$ & $<2$ & $<2$ & $<.4$ & $<1$ & $<.2$ & $<.3$ & $<.6$ & $<.3$ & $<.05$ & $<.06$ \\
\hline HK-23-14-404 & $<.03$ & $<.04$ & $<.1$ & $<2$ & $<2$ & $<.4$ & $<1$ & $<.2$ & $<.3$ & $<.6$ & $<.3$ & $<.05$ & $<.06$ \\
\hline HK-23-29-104 & $<.03$ & $<.04$ & $<.1$ & $<2$ & $<2$ & $<.4$ & $<1$ & $<.2$ & $<.3$ & $<.6$ & $<.3$ & $<.05$ & $<.06$ \\
\hline HS-28-09-808 & $<.03$ & $<.04$ & $<.1$ & $<2$ & $<2$ & $<.4$ & $<1$ & $<.2$ & $<.3$ & $<.6$ & $<.3$ & $<.05$ & $<.06$ \\
\hline HS-28-27-411 & $<.03$ & $<.04$ & $<.1$ & $<2$ & $<2$ & $<.4$ & $<1$ & $<.2$ & $<.3$ & $<.6$ & $<.3$ & $<.05$ & $<.06$ \\
\hline HT-10-13-345 & $<.03$ & $<.04$ & $<.1$ & $<2$ & $<2$ & $<.4$ & $<1$ & $<.2$ & $<.3$ & $<.6$ & $<.3$ & $<.05$ & $<.06$ \\
\hline HT-10-13-640 & $<.03$ & $<.04$ & $<.1$ & $<2$ & $<2$ & $<.4$ & $<1$ & $<.2$ & $<.3$ & $<.6$ & $<.3$ & $<.05$ & $<.06$ \\
\hline JW-23-08-101 & $<.03$ & $<.04$ & $<.1$ & $<2$ & $<2$ & $<.4$ & $<1$ & $<.2$ & $<.3$ & $<.6$ & $<.3$ & $<.05$ & $<.06$ \\
\hline KD-26-24-203 & $<.03$ & $<.04$ & $<.1$ & E3 & 10 & $<.4$ & $<1$ & $<.2$ & $<.3$ & $<.6$ & $<.3$ & $<.05$ & $<.06$ \\
\hline KD-27-01-807 & $<.03$ & $<.04$ & $<.1$ & $<2$ & $<2$ & $<.4$ & $<1$ & $<.2$ & $<.3$ & $<.6$ & $<.3$ & $<.05$ & $<.06$ \\
\hline KD-27-19-518 & $<.03$ & $<.04$ & $<.1$ & $<2$ & $<2$ & $<.4$ & $<1$ & $<.2$ & $<.3$ & $<.6$ & $<.3$ & $<.05$ & $<.06$ \\
\hline KD-27-30-103 & $<.03$ & $<.04$ & $<.1$ & $<2$ & $<2$ & $<.4$ & $<1$ & $<.2$ & $<.3$ & $<.6$ & $<.3$ & $<.05$ & $<.06$ \\
\hline KY-11-43-805 & $<.03$ & $<.04$ & $<.1$ & $<2$ & $<2$ & $<.4$ & $<1$ & $<.2$ & $<.3$ & $<.6$ & $<.3$ & $<.05$ & $<.06$ \\
\hline KY-11-49-207 & $<.03$ & $<.04$ & $<.1$ & $<2$ & $<2$ & $<.4$ & $<1$ & $<.2$ & $<.3$ & $<.6$ & $<.3$ & $<.05$ & $<.06$ \\
\hline KY-23-03-904 & $<.03$ & $<.04$ & $<.1$ & $<2$ & $<2$ & $<.4$ & $<1$ & $<.2$ & $<.3$ & $<.6$ & $<.3$ & $<.05$ & $<.06$ \\
\hline KY-23-10-304 & $<.03$ & $<.04$ & $<.1$ & $<2$ & $<2$ & $<.4$ & $<1$ & $<.2$ & $<.3$ & $<.6$ & $<.3$ & $<.05$ & $<.06$ \\
\hline PB-28-37-307 & $<.03$ & $<.04$ & $<.1$ & $<2$ & $<2$ & $<.4$ & $<1$ & $<.2$ & $<.3$ & $<.6$ & $<.3$ & $<.05$ & $<.06$ \\
\hline RU-10-52-107 & $<.03$ & $<.04$ & $<.1$ & $<2$ & $<2$ & $<.4$ & $<1$ & $<.2$ & $<.3$ & $<.6$ & $<.3$ & $<.05$ & $<.06$ \\
\hline RU-10-55-407 & $<.03$ & $<.04$ & $<.1$ & $<2$ & $<2$ & $<.4$ & $<1$ & $<.2$ & $<.3$ & $<.6$ & $<.3$ & $<.05$ & $<.06$ \\
\hline SP-23-17-712 & $<.03$ & $<.04$ & .5 & $<2$ & $<2$ & $<.4$ & $<1$ & $<.2$ & $<.3$ & $<.6$ & $<.3$ & $<.05$ & $<.06$ \\
\hline SP-23-25-904 & $<.03$ & $<.04$ & $<.1$ & $<2$ & $<2$ & $<.4$ & $<1$ & $<.2$ & $<.3$ & $<.6$ & $<.3$ & $<.05$ & $<.06$ \\
\hline SR-23-41-502 & $<.03$ & $<.04$ & $<.1$ & $<2$ & $<2$ & $<.4$ & $<1$ & $<.2$ & $<.3$ & $<.6$ & $<.3$ & $<.05$ & $<.06$ \\
\hline SY-27-48-611 & $<.03$ & $<.04$ & $<.1$ & $<2$ & $<2$ & $<.4$ & $<1$ & $<.2$ & $<.3$ & $<.6$ & $<.3$ & $<.05$ & $<.06$ \\
\hline SY-28-42-707 & $<.03$ & $<.04$ & $<.1$ & $<2$ & $<2$ & $<.4$ & $<1$ & $<.2$ & $<.3$ & $<.6$ & $<.3$ & $<.05$ & $<.06$ \\
\hline SY-28-58-204 & $<.03$ & $<.04$ & $<.1$ & $<2$ & $<2$ & $<.4$ & $<1$ & $<.2$ & $<.3$ & $<.6$ & $<.3$ & $<.05$ & $<.06$ \\
\hline $\mathrm{UH}-07-53-228$ & $<.03$ & $<.04$ & $<.1$ & $<2$ & $<2$ & $<.4$ & $<1$ & $<.2$ & $<.3$ & $<.6$ & $<.3$ & $<.05$ & $<.06$ \\
\hline UR-10-19-506 & $<.03$ & $<.04$ & $<.1$ & $<2$ & $<2$ & $<.4$ & $<1$ & $<.2$ & $<.3$ & $<.6$ & $<.3$ & $<.05$ & $<.06$ \\
\hline UR-10-42-204 & $<.03$ & $<.04$ & $<.1$ & $<2$ & $<2$ & $<.4$ & $<1$ & $<.2$ & $<.3$ & $<.6$ & $<.3$ & $<.05$ & $<.06$ \\
\hline UY-06-57-824 & $<.03$ & $<.04$ & $<.1$ & $<2$ & $<2$ & $<.4$ & $<1$ & $<.2$ & $<.3$ & $<.6$ & $<.3$ & $<.05$ & $<.06$ \\
\hline UY-10-07-631 & $<.03$ & $<.04$ & $<.1$ & $<2$ & $<2$ & $<.4$ & $<1$ & $<.2$ & $<.3$ & $<.6$ & $<.3$ & $<.05$ & $<.06$ \\
\hline XT-11-44-605 & $<.03$ & $<.04$ & $<.1$ & $<2$ & $<2$ & $<.4$ & $<1$ & $<.2$ & $<.3$ & $<.6$ & $<.3$ & $<.05$ & $<.06$ \\
\hline XY-24-45-502 & $<.03$ & $<.04$ & $<.1$ & $<2$ & $<2$ & $<.4$ & $<1$ & $<.2$ & $<.3$ & $<.6$ & $<.3$ & $<.05$ & $<.06$ \\
\hline$X Y-24-47-207$ & $<.03$ & $<.04$ & $<.1$ & $<2$ & $<2$ & $<.4$ & $<1$ & $<.2$ & $<.3$ & $<.6$ & $<.3$ & $<.05$ & $<.06$ \\
\hline$X Y-24-62-801$ & $<.03$ & $<.04$ & $<.1$ & $<2$ & $<2$ & $<.4$ & $<1$ & $<.2$ & $<.3$ & $<.6$ & $<.3$ & $<.05$ & $<.06$ \\
\hline ZT-24-43-202 & $<.03$ & $<.04$ & $<.1$ & $<2$ & $<2$ & $<.4$ & $<1$ & $<.2$ & $<.3$ & $<.6$ & $<.3$ & $<.05$ & $<.06$ \\
\hline ZT-24-50-602 & $<.03$ & $<.04$ & $<.1$ & $<2$ & $<2$ & $<.4$ & $<1$ & $<.2$ & $<.3$ & $<.6$ & $<.3$ & $<.05$ & $<.06$ \\
\hline ZT-25-40-8C & -- & -- & - & -- & -- & -- & -- & -- & -- & -- & -- & -- & -- \\
\hline
\end{tabular}


Appendix 7. Volatile organic compound concentrations in water sampled from primarily domestic wells screened in the southern High Plains aquifer, Texas and New Mexico, 2001—Continued

\begin{tabular}{|c|c|c|c|c|c|c|c|c|c|c|c|}
\hline $\begin{array}{c}\text { State } \\
\text { well no. }\end{array}$ & $\begin{array}{c}\text { Methane, } \\
\text { bromo- } \\
\text { chloro- }\end{array}$ & $\begin{array}{c}\text { Methane, } \\
\text { bromo- } \\
\text { dichloro- }\end{array}$ & $\begin{array}{c}\text { Methane, } \\
\text { dibromo- } \\
\text { chloro- }\end{array}$ & $\begin{array}{l}\text { Methane, } \\
\text { chloro- }\end{array}$ & $\begin{array}{l}\text { Methane, } \\
\text { dichloro- }\end{array}$ & $\begin{array}{l}\text { Methane, } \\
\text { dichloro- } \\
\text { difluoro- }\end{array}$ & $\begin{array}{l}\text { Methane, } \\
\text { trichloro- }\end{array}$ & $\begin{array}{c}\text { Methane, } \\
\text { trichloro- } \\
\text { fluoro- }\end{array}$ & $\begin{array}{l}\text { Methane- } \\
\text { tetrachloro- }\end{array}$ & $\begin{array}{l}\text { Methane, } \\
\text { iodo- }\end{array}$ & $\begin{array}{l}\text { Naphtha- } \\
\text { ene }\end{array}$ \\
\hline & & & & $\begin{array}{l}\text { Methyl } \\
\text { chloride }\end{array}$ & $\begin{array}{l}\text { Methylene } \\
\text { chloride }\end{array}$ & $\begin{array}{l}\text { Freon 12, } \\
\text { CFC } 12\end{array}$ & $\begin{array}{l}\text { Chloro- } \\
\text { form }\end{array}$ & $\begin{array}{l}\text { Freon 11, } \\
\text { CFC } 11\end{array}$ & $\begin{array}{c}\text { Carbon } \\
\text { tetra- } \\
\text { chloride }\end{array}$ & $\begin{array}{l}\text { Methyl } \\
\text { iodide }\end{array}$ & \\
\hline NM03N.36E.28.411 & $<0.04$ & $<0.05$ & $<0.2$ & $<0.2$ & $<0.2$ & $<0.3$ & $<0.02$ & $<0.09$ & $<0.06$ & $<0.1$ & $<0.5$ \\
\hline NM05N.34E.36.244 & $<.04$ & $<.05$ & $<.2$ & $<.2$ & $<.2$ & $<.3$ & $<.02$ & $<.09$ & $<.06$ & $<.1$ & $<.5$ \\
\hline NM13S.38E.14.3333A & $<.04$ & $<.05$ & $<.2$ & $<.2$ & $<.2$ & $<.3$ & $<.02$ & $<.09$ & $<.06$ & $<.1$ & $<.5$ \\
\hline NM15S.38E.14.211 & $<.04$ & $<.05$ & $<.2$ & $<.2$ & $<.2$ & $<.3$ & $<.02$ & $<.09$ & $<.06$ & $<.1$ & $<.5$ \\
\hline NM01N.36E.21.233 & $<.04$ & $<.05$ & $<.2$ & $<.2$ & $<.2$ & $<.3$ & $<.02$ & $<.09$ & $<.06$ & $<.1$ & $<.5$ \\
\hline NM02S.36E.17.231 & $<.04$ & $<.05$ & $<.2$ & $<.2$ & $<.2$ & $<.3$ & $<.02$ & $<.09$ & $<.06$ & $<.1$ & $<.5$ \\
\hline AB-27-29-905 & $<.04$ & $<.05$ & $<.2$ & $<.2$ & $<.2$ & $<.3$ & $<.02$ & $<.09$ & $<.06$ & $<.1$ & $<.5$ \\
\hline AR-25-08-603 & $<.04$ & $<.05$ & $<.2$ & $<.2$ & $<.2$ & $<.3$ & $<.02$ & $<.09$ & $<.06$ & $<.1$ & $<.5$ \\
\hline BL-11-38-925 & $<.04$ & $<.05$ & $<.2$ & $<.2$ & $<.2$ & $<.3$ & $<.02$ & $<.09$ & $<.06$ & $<.1$ & $<.5$ \\
\hline DD-10-30-803 & $<.04$ & $<.05$ & $<.2$ & $<.2$ & $<.2$ & $<.3$ & $<.02$ & $<.09$ & $<.06$ & $<.1$ & $<.5$ \\
\hline DP-24-19-405 & $<.04$ & $<.05$ & $<.2$ & $<.2$ & $<.2$ & $<.3$ & $<.02$ & $<.09$ & $<.06$ & $<.1$ & $<.5$ \\
\hline DP-24-20-705 & $<.04$ & $<.05$ & $<.2$ & $<.2$ & $<.2$ & $<.3$ & $<.02$ & $<.09$ & $<.06$ & $<.1$ & $<.5$ \\
\hline HK-23-14-404 & $<.04$ & $<.05$ & $<.2$ & $<.2$ & $<.2$ & $<.3$ & $<.02$ & $<.09$ & $<.06$ & $<.1$ & $<.5$ \\
\hline HK-23-29-104 & $<.04$ & $<.05$ & $<.2$ & $<.2$ & $<.2$ & $<.3$ & $<.02$ & $<.09$ & $<.06$ & $<.1$ & $<.5$ \\
\hline HS-28-09-808 & $<.04$ & $<.05$ & $<.2$ & $<.2$ & $<.2$ & $<.3$ & $<.02$ & $<.09$ & $<.06$ & $<.1$ & $<.5$ \\
\hline HS-28-27-411 & $<.04$ & $<.05$ & $<.2$ & $<.2$ & $<.2$ & $<.3$ & 1.51 & $<.09$ & $<.06$ & $<.1$ & $<.5$ \\
\hline HT-10-13-345 & $<.04$ & $<.05$ & $<.2$ & $<.2$ & $<.2$ & $<.3$ & $<.02$ & $<.09$ & $<.06$ & $<.1$ & $<.5$ \\
\hline HT-10-13-640 & $<.04$ & $<.05$ & $<.2$ & $<.2$ & $<.2$ & $<.3$ & $<.02$ & $<.09$ & $<.06$ & $<.1$ & $<.5$ \\
\hline JW-23-08-101 & $<.04$ & $<.05$ & $<.2$ & $<.2$ & $<.2$ & $<.3$ & $<.02$ & $<.09$ & $<.06$ & $<.1$ & $<.5$ \\
\hline KD-26-24-203 & $<.04$ & $<.05$ & $<.2$ & $<.2$ & $<.2$ & $<.3$ & $<.02$ & $<.09$ & $<.06$ & $<.1$ & $<.5$ \\
\hline KD-27-01-807 & $<.04$ & $<.05$ & $<.2$ & $<.2$ & $<.2$ & $<.3$ & $<.02$ & $<.09$ & $<.06$ & $<.1$ & $<.5$ \\
\hline KD-27-19-518 & $<.04$ & $<.05$ & $<.2$ & $<.2$ & $<.2$ & $<.3$ & $<.02$ & $<.09$ & $<.06$ & $<.1$ & $<.5$ \\
\hline KD-27-30-103 & $<.04$ & $<.05$ & $<.2$ & $<.2$ & $<.2$ & $<.3$ & E.07 & $<.09$ & $<.06$ & $<.1$ & $<.5$ \\
\hline$K Y-11-43-805$ & $<.04$ & $<.05$ & $<.2$ & $<.2$ & $<.2$ & $<.3$ & $<.02$ & $<.09$ & $<.06$ & $<.1$ & $<.5$ \\
\hline KY-11-49-207 & $<.04$ & $<.05$ & $<.2$ & $<.2$ & $<.2$ & $<.3$ & $<.02$ & $<.09$ & $<.06$ & $<.1$ & $<.5$ \\
\hline $\mathrm{KY}-23-03-904$ & $<.04$ & $<.05$ & $<.2$ & $<.2$ & $<.2$ & $<.3$ & $<.02$ & $<.09$ & $<.06$ & $<.1$ & $<.5$ \\
\hline $\mathrm{KY}-23-10-304$ & $<.04$ & $<.05$ & $<.2$ & $<.2$ & $<.2$ & $<.3$ & $<.02$ & $<.09$ & $<.06$ & $<.1$ & $<.5$ \\
\hline PB-28-37-307 & $<.04$ & $<.05$ & $<.2$ & $<.2$ & $<.2$ & $<.3$ & $<.02$ & $<.09$ & $<.06$ & $<.1$ & $<.5$ \\
\hline RU-10-52-107 & $<.04$ & $<.05$ & $<.2$ & $<.2$ & $<.2$ & $<.3$ & $<.02$ & $<.09$ & $<.06$ & $<.1$ & $<.5$ \\
\hline RU-10-55-407 & $<.04$ & $<.05$ & $<.2$ & $<.2$ & $<.2$ & $<.3$ & $<.02$ & $<.09$ & $<.06$ & $<.1$ & $<.5$ \\
\hline $\mathrm{SP}-23-17-712$ & $<.04$ & $<.05$ & $<.2$ & $<.2$ & $<.2$ & $<.3$ & $<.02$ & $<.09$ & $<.06$ & $<.1$ & $<.5$ \\
\hline $\mathrm{SP}-23-25-904$ & $<.04$ & $<.05$ & $<.2$ & $<.2$ & $<.2$ & $<.3$ & $<.02$ & $<.09$ & $<.06$ & $<.1$ & $<.5$ \\
\hline SR-23-41-502 & $<.04$ & $<.05$ & $<.2$ & $<.2$ & $<.2$ & $<.3$ & $<.02$ & $<.09$ & $<.06$ & $<.1$ & $<.5$ \\
\hline$S Y-27-48-611$ & $<.04$ & $<.05$ & $<.2$ & $<.2$ & $<.2$ & $<.3$ & $<.02$ & $<.09$ & $<.06$ & $<.1$ & $<.5$ \\
\hline SY-28-42-707 & $<.04$ & $<.05$ & $<.2$ & $<.2$ & $<.2$ & $<.3$ & $<.02$ & $<.09$ & $<.06$ & $<.1$ & $<.5$ \\
\hline SY-28-58-204 & $<.04$ & $<.05$ & $<.2$ & $<.2$ & $<.2$ & $<.3$ & E.05 & $<.09$ & $<.06$ & $<.1$ & $<.5$ \\
\hline UH-07-53-228 & $<.04$ & $<.05$ & $<.2$ & $<.2$ & $<.2$ & $<.3$ & $<.02$ & $<.09$ & $<.06$ & $<.1$ & $<.5$ \\
\hline UR-10-19-506 & $<.04$ & $<.05$ & $<.2$ & $<.2$ & $<.2$ & $<.3$ & $<.02$ & $<.09$ & $<.06$ & $<.1$ & $<.5$ \\
\hline UR-10-42-204 & $<.04$ & $<.05$ & $<.2$ & $<.2$ & $<.2$ & $<.3$ & $<.02$ & $<.09$ & $<.06$ & $<.1$ & $<.5$ \\
\hline UY-06-57-824 & $<.04$ & $<.05$ & $<.2$ & $<.2$ & $<.2$ & $<.3$ & $<.02$ & $<.09$ & $<.06$ & $<.1$ & $<.5$ \\
\hline UY-10-07-631 & $<.04$ & $<.05$ & $<.2$ & $<.2$ & $<.2$ & $<.3$ & $<.02$ & $<.09$ & $<.06$ & $<.1$ & $<.5$ \\
\hline XT-11-44-605 & $<.04$ & $<.05$ & $<.2$ & $<.2$ & $<.2$ & $<.3$ & $<.02$ & $<.09$ & $<.06$ & $<.1$ & $<.5$ \\
\hline$X Y-24-45-502$ & $<.04$ & $<.05$ & $<.2$ & $<.2$ & $<.2$ & $<.3$ & $<.02$ & $<.09$ & $<.06$ & $<.1$ & $<.5$ \\
\hline$X Y-24-47-207$ & $<.04$ & $<.05$ & $<.2$ & $<.2$ & $<.2$ & $<.3$ & E.09 & $<.09$ & $<.06$ & $<.1$ & $<.5$ \\
\hline$X Y-24-62-801$ & $<.04$ & $<.05$ & $<.2$ & $<.2$ & $<.2$ & $<.3$ & $<.02$ & $<.09$ & $<.06$ & $<.1$ & $<.5$ \\
\hline ZT-24-43-202 & $<.04$ & $<.05$ & $<.2$ & $<.2$ & $<.2$ & $<.3$ & $<.02$ & $<.09$ & $<.06$ & $<.1$ & $<.5$ \\
\hline ZT-24-50-602 & $<.04$ & $<.05$ & $<.2$ & $<.2$ & $<.2$ & $<.3$ & $<.02$ & $<.09$ & $<.06$ & $<.1$ & $<.5$ \\
\hline $\mathrm{ZT}-25-40-804$ & -- & -- & -- & -- & -- & -- & -- & -- & -- & -- & -- \\
\hline
\end{tabular}


Appendix 7. Volatile organic compound concentrations in water sampled from primarily domestic wells screened in the southern High Plains aquifer, Texas and New Mexico, 2001—Continued

\begin{tabular}{|c|c|c|c|c|c|c|c|c|c|}
\hline $\begin{array}{c}\text { State } \\
\text { well no. }\end{array}$ & $\begin{array}{c}\text { Propane, } \\
\text { 1,2-dichloro- }\end{array}$ & $\begin{array}{c}\text { Propane, } \\
\text { 1,3-dichloro- }\end{array}$ & $\begin{array}{c}\text { Propane, } \\
\text { 2,2-dichloro- }\end{array}$ & $\begin{array}{c}\text { Propane, } \\
1,2,3- \\
\text { trichloro- }\end{array}$ & $\begin{array}{l}\text { Propane, 1,2- } \\
\text { dibromo- } \\
\text { 3-chloro- }\end{array}$ & $\begin{array}{l}\text { Propene, } \\
\text { 3-chloro- }\end{array}$ & $\begin{array}{c}\text { Propene, } \\
\text { 1,1-dichloro- }\end{array}$ & $\begin{array}{l}\text { Propene, } \\
\text { cis-1,3- } \\
\text { dichloro- }\end{array}$ & $\begin{array}{l}\text { Propene, } \\
\text { trans-1,3- } \\
\text { dichloro- }\end{array}$ \\
\hline & $\begin{array}{l}\text { Propylene } \\
\text { dichloride }\end{array}$ & & & & $\begin{array}{c}\text { Propane, } \\
\text { dibromo- } \\
\text { chloro-; DBCP }\end{array}$ & & & & \\
\hline NM03N.36E.28.411 & $<0.03$ & $<0.1$ & $<0.05$ & $<0.2$ & $<0.5$ & $<0.1$ & $<0.03$ & $<0.09$ & $<0.09$ \\
\hline NM05N.34E.36.244 & $<.03$ & $<.1$ & $<.05$ & $<.2$ & $<.5$ & $<.1$ & $<.03$ & $<.09$ & $<.09$ \\
\hline NM13S.38E.14.3333A & $<.03$ & $<.1$ & $<.05$ & $<.2$ & $<.5$ & $<.1$ & $<.03$ & $<.09$ & $<.09$ \\
\hline NM15S.38E.14.211 & $<.03$ & $<.1$ & $<.05$ & $<.2$ & $<.5$ & $<.1$ & $<.03$ & $<.09$ & $<.09$ \\
\hline NM01N.36E.21.233 & $<.03$ & $<.1$ & $<.05$ & $<.2$ & $<.5$ & $<.1$ & $<.03$ & $<.09$ & $<.09$ \\
\hline NM02S.36E.17.231 & $<.03$ & $<.1$ & $<.05$ & $<.2$ & $<.5$ & $<.1$ & $<.03$ & $<.09$ & $<.09$ \\
\hline AB-27-29-905 & $<.03$ & $<.1$ & $<.05$ & $<.2$ & $<.5$ & $<.1$ & $<.03$ & $<.09$ & $<.09$ \\
\hline AR-25-08-603 & $<.03$ & $<.1$ & $<.05$ & $<.2$ & $<.5$ & $<.1$ & $<.03$ & $<.09$ & $<.09$ \\
\hline BL-11-38-925 & $<.03$ & $<.1$ & $<.05$ & $<.2$ & $<.5$ & $<.1$ & $<.03$ & $<.09$ & $<.09$ \\
\hline DD-10-30-803 & $<.03$ & $<.1$ & $<.05$ & $<.2$ & $<.5$ & $<.1$ & $<.03$ & $<.09$ & $<.09$ \\
\hline DP-24-19-405 & $<.03$ & $<.1$ & $<.05$ & $<.2$ & $<.5$ & $<.1$ & $<.03$ & $<.09$ & $<.09$ \\
\hline DP-24-20-705 & $<.03$ & $<.1$ & $<.05$ & $<.2$ & $<.5$ & $<.1$ & $<.03$ & $<.09$ & $<.09$ \\
\hline HK-23-14-404 & $<.03$ & $<.1$ & $<.05$ & $<.2$ & $<.5$ & $<.1$ & $<.03$ & $<.09$ & $<.09$ \\
\hline HK-23-29-104 & $<.03$ & $<.1$ & $<.05$ & $<.2$ & $<.5$ & $<.1$ & $<.03$ & $<.09$ & $<.09$ \\
\hline HS-28-09-808 & $<.03$ & $<.1$ & $<.05$ & $<.2$ & $<.5$ & $<.1$ & $<.03$ & $<.09$ & $<.09$ \\
\hline HS-28-27-411 & $<.03$ & $<.1$ & $<.05$ & $<.2$ & $<.5$ & $<.1$ & $<.03$ & $<.09$ & $<.09$ \\
\hline HT-10-13-345 & $<.03$ & $<.1$ & $<.05$ & $<.2$ & $<.5$ & $<.1$ & $<.03$ & $<.09$ & $<.09$ \\
\hline HT-10-13-640 & $<.03$ & $<.1$ & $<.05$ & $<.2$ & $<.5$ & $<.1$ & $<.03$ & $<.09$ & $<.09$ \\
\hline JW-23-08-101 & $<.03$ & $<.1$ & $<.05$ & $<.2$ & $<.5$ & $<.1$ & $<.03$ & $<.09$ & $<.09$ \\
\hline KD-26-24-203 & $<.03$ & $<.1$ & $<.05$ & $<.2$ & $<.5$ & $<.1$ & $<.03$ & $<.09$ & $<.09$ \\
\hline KD-27-01-807 & $<.03$ & $<.1$ & $<.05$ & $<.2$ & $<.5$ & $<.1$ & $<.03$ & $<.09$ & $<.09$ \\
\hline KD-27-19-518 & $<.03$ & $<.1$ & $<.05$ & $<.2$ & $<.5$ & $<.1$ & $<.03$ & $<.09$ & $<.09$ \\
\hline KD-27-30-103 & $<.03$ & $<.1$ & $<.05$ & $<.2$ & $<.5$ & $<.1$ & $<.03$ & $<.09$ & $<.09$ \\
\hline KY-11-43-805 & $<.03$ & $<.1$ & $<.05$ & $<.2$ & $<.5$ & $<.1$ & $<.03$ & $<.09$ & $<.09$ \\
\hline KY-11-49-207 & $<.03$ & $<.1$ & $<.05$ & $<.2$ & $<.5$ & $<.1$ & $<.03$ & $<.09$ & $<.09$ \\
\hline KY-23-03-904 & $<.03$ & $<.1$ & $<.05$ & $<.2$ & $<.5$ & $<.1$ & $<.03$ & $<.09$ & $<.09$ \\
\hline $\mathrm{KY}-23-10-304$ & $<.03$ & $<.1$ & $<.05$ & $<.2$ & $<.5$ & $<.1$ & $<.03$ & $<.09$ & $<.09$ \\
\hline PB-28-37-307 & $<.03$ & $<.1$ & $<.05$ & $<.2$ & $<.5$ & $<.1$ & $<.03$ & $<.09$ & $<.09$ \\
\hline RU-10-52-107 & $<.03$ & $<.1$ & $<.05$ & $<.2$ & $<.5$ & $<.1$ & $<.03$ & $<.09$ & $<.09$ \\
\hline RU-10-55-407 & $<.03$ & $<.1$ & $<.05$ & $<.2$ & $<.5$ & $<.1$ & $<.03$ & $<.09$ & $<.09$ \\
\hline SP-23-17-712 & $<.03$ & $<.1$ & $<.05$ & $<.2$ & $<.5$ & $<.1$ & $<.03$ & $<.09$ & $<.09$ \\
\hline SP-23-25-904 & $<.03$ & $<.1$ & $<.05$ & $<.2$ & $<.5$ & $<.1$ & $<.03$ & $<.09$ & $<.09$ \\
\hline SR-23-41-502 & $<.03$ & $<.1$ & $<.05$ & $<.2$ & $<.5$ & $<.1$ & $<.03$ & $<.09$ & $<.09$ \\
\hline SY $-27-48-611$ & $<.03$ & $<.1$ & $<.05$ & $<.2$ & $<.5$ & $<.1$ & $<.03$ & $<.09$ & $<.09$ \\
\hline SY-28-42-707 & $<.03$ & $<.1$ & $<.05$ & $<.2$ & $<.5$ & $<.1$ & $<.03$ & $<.09$ & $<.09$ \\
\hline SY-28-58-204 & $<.03$ & $<.1$ & $<.05$ & $<.2$ & $<.5$ & $<.1$ & $<.03$ & $<.09$ & $<.09$ \\
\hline UH-07-53-228 & $<.03$ & $<.1$ & $<.05$ & $<.2$ & $<.5$ & $<.1$ & $<.03$ & $<.09$ & $<.09$ \\
\hline UR-10-19-506 & $<.03$ & $<.1$ & $<.05$ & $<.2$ & $<.5$ & $<.1$ & $<.03$ & $<.09$ & $<.09$ \\
\hline UR-10-42-204 & $<.03$ & $<.1$ & $<.05$ & $<.2$ & $<.5$ & $<.1$ & $<.03$ & $<.09$ & $<.09$ \\
\hline UY-06-57-824 & $<.03$ & $<.1$ & $<.05$ & $<.2$ & $<.5$ & $<.1$ & $<.03$ & $<.09$ & $<.09$ \\
\hline UY-10-07-631 & $<.03$ & $<.1$ & $<.05$ & $<.2$ & $<.5$ & $<.1$ & $<.03$ & $<.09$ & $<.09$ \\
\hline XT-11-44-605 & $<.03$ & $<.1$ & $<.05$ & $<.2$ & $<.5$ & $<.1$ & $<.03$ & $<.09$ & $<.09$ \\
\hline$X Y-24-45-502$ & $<.03$ & $<.1$ & $<.05$ & $<.2$ & $<.5$ & $<.1$ & $<.03$ & $<.09$ & $<.09$ \\
\hline$X Y-24-47-207$ & $<.03$ & $<.1$ & $<.05$ & $<.2$ & $<.5$ & $<.1$ & $<.03$ & $<.09$ & $<.09$ \\
\hline $\mathrm{XY}-24-62-801$ & $<.03$ & $<.1$ & $<.05$ & $<.2$ & $<.5$ & $<.1$ & $<.03$ & $<.09$ & $<.09$ \\
\hline ZT-24-43-202 & $<.03$ & $<.1$ & $<.05$ & $<.2$ & $<.5$ & $<.1$ & $<.03$ & $<.09$ & $<.09$ \\
\hline ZT-24-50-602 & $<.03$ & $<.1$ & $<.05$ & $<.2$ & $<.5$ & $<.1$ & $<.03$ & $<.09$ & $<.09$ \\
\hline ZT-25-40-804 & -- & -- & -- & -- & -- & -- & -- & -- & -- \\
\hline
\end{tabular}


Appendix 7. Volatile organic compound concentrations in water sampled from primarily domestic wells screened in the southern High Plains aquifer, Texas and New Mexico, 2001—Continued

\begin{tabular}{|c|c|c|c|c|c|c|c|c|}
\hline $\begin{array}{c}\text { State } \\
\text { well no. }\end{array}$ & Styrene & Toluene & $\begin{array}{l}\text { Toluene, } \\
\text { o-chloro- }\end{array}$ & $\begin{array}{l}\text { Toluene, } \\
p \text {-chloro- }\end{array}$ & $\begin{array}{c}\text { Toluene, } \\
\text { o-ethyl }\end{array}$ & $\begin{array}{c}\text { Toluene, } \\
\text { 4-isopropyl- }\end{array}$ & $\begin{array}{c}m / p- \\
\text { Xylene }\end{array}$ & o-Xylene \\
\hline & & & & & & P-cymene & $\begin{array}{c}\text { Benzene, } \\
\text { 1,3- and } \\
\text { 1,4-dimethyl- }\end{array}$ & $\begin{array}{c}\text { Benzene, } \\
\text { 1,2- } \\
\text { dimethyl- }\end{array}$ \\
\hline NM03N.36E.28.411 & $<0.04$ & $<0.05$ & $<0.03$ & $<0.06$ & $<0.06$ & $<0.07$ & $<0.06$ & $<0.04$ \\
\hline NM05N.34E.36.244 & $<.04$ & $<.05$ & $<.03$ & $<.06$ & $<.06$ & $<.07$ & $<.06$ & $<.04$ \\
\hline NM13S.38E.14.3333A & $<.04$ & $<.05$ & $<.03$ & $<.06$ & $<.06$ & $<.07$ & $<.06$ & $<.04$ \\
\hline NM15S.38E.14.211 & $<.04$ & $<.05$ & $<.03$ & $<.06$ & $<.06$ & $<.07$ & $<.06$ & $<.04$ \\
\hline NM01N.36E.21.233 & $<.04$ & $<.05$ & $<.03$ & $<.06$ & $<.06$ & $<.07$ & $<.06$ & $<.04$ \\
\hline NM02S.36E.17.231 & $<.04$ & $<.05$ & $<.03$ & $<.06$ & $<.06$ & $<.07$ & $<.06$ & $<.04$ \\
\hline $\mathrm{AB}-27-29-905$ & $<.04$ & $<.05$ & $<.03$ & $<.06$ & $<.06$ & $<.07$ & $<.06$ & $<.04$ \\
\hline AR-25-08-603 & $<.04$ & $<.05$ & $<.03$ & $<.06$ & $<.06$ & $<.07$ & $<.06$ & $<.04$ \\
\hline BL-11-38-925 & $<.04$ & $<.05$ & $<.03$ & $<.06$ & $<.06$ & $<.07$ & $<.06$ & $<.04$ \\
\hline DD-10-30-803 & $<.04$ & $<.05$ & $<.03$ & $<.06$ & $<.06$ & $<.07$ & $<.06$ & $<.04$ \\
\hline DP-24-19-405 & $<.04$ & $<.05$ & $<.03$ & $<.06$ & $<.06$ & $<.07$ & $<.06$ & $<.04$ \\
\hline $\mathrm{DP}-24-20-705$ & $<.04$ & $<.05$ & $<.03$ & $<.06$ & $<.06$ & $<.07$ & $<.06$ & $<.04$ \\
\hline HK-23-14-404 & $<.04$ & $<.05$ & $<.03$ & $<.06$ & $<.06$ & $<.07$ & $<.06$ & $<.04$ \\
\hline HK-23-29-104 & $<.04$ & $<.05$ & $<.03$ & $<.06$ & $<.06$ & $<.07$ & $<.06$ & $<.04$ \\
\hline HS-28-09-808 & $<.04$ & $<.05$ & $<.03$ & $<.06$ & $<.06$ & $<.07$ & $<.06$ & $<.04$ \\
\hline HS-28-27-411 & $<.04$ & $<.05$ & $<.03$ & $<.06$ & $<.06$ & $<.07$ & $<.06$ & $<.04$ \\
\hline HT-10-13-345 & $<.04$ & $<.05$ & $<.03$ & $<.06$ & $<.06$ & $<.07$ & $<.06$ & $<.04$ \\
\hline HТ-10-13-640 & $<.04$ & $<.05$ & $<.03$ & $<.06$ & $<.06$ & $<.07$ & $<.06$ & $<.04$ \\
\hline JW-23-08-101 & $<.04$ & $<.05$ & $<.03$ & $<.06$ & $<.06$ & $<.07$ & $<.06$ & $<.04$ \\
\hline KD-26-24-203 & $<.04$ & $<.05$ & $<.03$ & $<.06$ & $<.06$ & $<.07$ & $<.06$ & $<.04$ \\
\hline KD-27-01-807 & $<.04$ & $<.05$ & $<.03$ & $<.06$ & $<.06$ & $<.07$ & $<.06$ & $<.04$ \\
\hline KD-27-19-518 & $<.04$ & $<.05$ & $<.03$ & $<.06$ & $<.06$ & $<.07$ & $<.06$ & $<.04$ \\
\hline KD-27-30-103 & $<.04$ & $<.05$ & $<.03$ & $<.06$ & $<.06$ & $<.07$ & $<.06$ & $<.04$ \\
\hline $\mathrm{KY}-11-43-805$ & $<.04$ & $<.05$ & $<.03$ & $<.06$ & $<.06$ & $<.07$ & $<.06$ & $<.04$ \\
\hline KY-11-49-207 & $<.04$ & $<.05$ & $<.03$ & $<.06$ & $<.06$ & $<.07$ & $<.06$ & $<.04$ \\
\hline KY-23-03-904 & $<.04$ & $<.05$ & $<.03$ & $<.06$ & $<.06$ & $<.07$ & $<.06$ & $<.04$ \\
\hline $\mathrm{KY}-23-10-304$ & $<.04$ & $<.05$ & $<.03$ & $<.06$ & $<.06$ & $<.07$ & $<.06$ & $<.04$ \\
\hline PB-28-37-307 & $<.04$ & $<.05$ & $<.03$ & $<.06$ & $<.06$ & $<.07$ & $<.06$ & $<.04$ \\
\hline RU-10-52-107 & $<.04$ & $<.05$ & $<.03$ & $<.06$ & $<.06$ & $<.07$ & $<.06$ & $<.04$ \\
\hline RU-10-55-407 & $<.04$ & $<.05$ & $<.03$ & $<.06$ & $<.06$ & $<.07$ & $<.06$ & $<.04$ \\
\hline SP-23-17-712 & $<.04$ & $<.05$ & $<.03$ & $<.06$ & $<.06$ & $<.07$ & $<.06$ & $<.04$ \\
\hline $\mathrm{SP}-23-25-904$ & $<.04$ & $<.05$ & $<.03$ & $<.06$ & $<.06$ & $<.07$ & $<.06$ & $<.04$ \\
\hline SR-23-41-502 & $<.04$ & $<.05$ & $<.03$ & $<.06$ & $<.06$ & $<.07$ & $<.06$ & $<.04$ \\
\hline SY-27-48-611 & $<.04$ & $<.05$ & $<.03$ & $<.06$ & $<.06$ & $<.07$ & $<.06$ & $<.04$ \\
\hline SY-28-42-707 & $<.04$ & $<.05$ & $<.03$ & $<.06$ & $<.06$ & $<.07$ & $<.06$ & $<.04$ \\
\hline SY-28-58-204 & $<.04$ & $<.05$ & $<.03$ & $<.06$ & $<.06$ & $<.07$ & $<.06$ & $<.04$ \\
\hline UH-07-53-228 & $<.04$ & $<.05$ & $<.03$ & $<.06$ & $<.06$ & $<.07$ & $<.06$ & $<.04$ \\
\hline UR-10-19-506 & $<.04$ & $<.05$ & $<.03$ & $<.06$ & $<.06$ & $<.07$ & $<.06$ & $<.04$ \\
\hline UR-10-42-204 & $<.04$ & $<.05$ & $<.03$ & $<.06$ & $<.06$ & $<.07$ & $<.06$ & $<.04$ \\
\hline UY-06-57-824 & $<.04$ & $<.05$ & $<.03$ & $<.06$ & $<.06$ & $<.07$ & $<.06$ & $<.04$ \\
\hline UY-10-07-631 & $<.04$ & $<.05$ & $<.03$ & $<.06$ & $<.06$ & $<.07$ & $<.06$ & $<.04$ \\
\hline $\mathrm{XT}-11-44-605$ & $<.04$ & $<.05$ & $<.03$ & $<.06$ & $<.06$ & $<.07$ & $<.06$ & $<.04$ \\
\hline$X Y-24-45-502$ & $<.04$ & $<.05$ & $<.03$ & $<.06$ & $<.06$ & $<.07$ & $<.06$ & $<.04$ \\
\hline$X Y-24-47-207$ & $<.04$ & $<.05$ & $<.03$ & $<.06$ & $<.06$ & $<.07$ & $<.06$ & $<.04$ \\
\hline$X Y-24-62-801$ & $<.04$ & $<.05$ & $<.03$ & $<.06$ & $<.06$ & $<.07$ & $<.06$ & $<.04$ \\
\hline ZT-24-43-202 & $<.04$ & $<.05$ & $<.03$ & $<.06$ & $<.06$ & $<.07$ & $<.06$ & $<.04$ \\
\hline ZT-24-50-602 & $<.04$ & $<.05$ & $<.03$ & $<.06$ & $<.06$ & $<.07$ & $<.06$ & $<.04$ \\
\hline ZT-25-40-804 & -- & -- & -- & -- & -- & -- & -- & -- \\
\hline
\end{tabular}




\section{Appendix 8. Quality-control and ancillary information associated with water-quality data presented in this report}

Quality-control (QC) samples are collected and analyzed to evaluate bias and variability of environmental samples. Bias is systematic error inherent in a method or caused by some artifact of the measurement system. Variability is the degree of variation in independent measurements as a result of repeated application of the process under specified conditions (T.L. Schertz, U.S. Geological Survey, written commun., 1997). QC data are particularly useful for analyzing and interpreting waterquality data collected for small levels of measurement, for example micrograms per liter (parts per billion) for many constituents analyzed for this study. For understanding "small level" detections in this report, about 0.05 microgram per liter $(\mu \mathrm{g} / \mathrm{L})$ is equivalent to measuring the concentration of an aspirin tablet dissolved in an Olympic-size swimming pool. QC samples collected and analyzed for this study consisted of three types of samples collected onsite: blanks, replicate environmental, and environmental matrix-spike samples. In addition to QC samples submitted from the field, the U.S. Geological Survey (USGS) National Water Quality Laboratory (NWQL) analyzes laboratory blanks, replicates, and spikes. QC data stored in USGS databases are available upon request.

Blank samples test for bias from introduction of contaminants to environmental samples. Four types of blank samples were analyzed in this study: source-solution, equipment, trip, and field. Source-solution blanks consist of high-purity organics-free water, prepared and tested by the NWQL for the National Water-Quality Assessment Program. Source-solution blanks, analyzed only for volatile organic compounds (VOCs) and dissolved organic carbon (DOC) when detected in equipment and field blanks, document the purity of these high-purity waters used to collect field and equipment blanks. Two equipment blanks were collected prior to collection of the first environmental samples to indicate whether the equipment or sample-collection process would bias the data. Two trip blanks, which are sealed vials of high-purity water prepared in the laboratory, transported to the field, and shipped back to the laboratory, were used to assess the possibility of contamination during field activities, transport, and shipping of samples.

Field blanks were collected at regular intervals onsite to indicate whether analytical bias occurred from sample collection, cleaning protocols, or contamination of the mobile laboratory. Six field blanks were collected onsite following environmental sample collection and subsequent equipment cleaning. Field blanks were processed the same as environmental samples-by pumping high-purity water through cleaned sample-collection equipment, including filter apparatuses, where applicable.

Two trip blanks were analyzed for VOCs. Equipment and field blanks were analyzed for concentrations of major ions, nutrients, DOC, trace elements, pesticides, and VOCs. DOC was detected in the two equipment blanks and was attributed to residual detergent not removed during cleaning. The cleaning process was "corrected" before sampling began. Toluene was the only VOC detected in trip and source-solution blanks, but it was not detected in environmental samples. DOC was not detected above the LRL in source-solution blanks. VOCs detected in field blanks were styrene and toluene, compounds not detected in environmental samples. DOC was measured above the LRL in one field blank at an estimated concentration of 0.33 milligram per liter $(\mathrm{mg} / \mathrm{L})$; however, this detection was smaller than the lowest environmental detection of $0.37 \mathrm{mg} / \mathrm{L}$. Nutrients and pesticides were not detected above minimum reporting levels or laboratory reporting levels (LRLs) in field blanks. Inorganic constituents detected in field blanks were boron, $9 \mu \mathrm{g} / \mathrm{L}$; bromide, two detections of $0.02 \mathrm{mg} / \mathrm{L}$; lithium, $0.4 \mu \mathrm{g} / \mathrm{L}$; and strontium, $0.3,0.1 \mathrm{mg} / \mathrm{L}$. Detections of these constituents in field blanks were smaller than the smallest environmental measurements for each constituent: boron, $73 \mu \mathrm{g} / \mathrm{L}$; bromide, $0.07 \mathrm{mg} / \mathrm{L}$; lithium, $0.2 \mu \mathrm{g} / \mathrm{L}$; and strontium, $565 \mathrm{mg} / \mathrm{L}$. Zinc was detected in field blanks, two detections of $2 \mu \mathrm{g} / \mathrm{L}$, at concentrations comparable to the smallest environmental measurements of $1 \mu \mathrm{g} / \mathrm{L}$; therefore, zinc concentrations at or below $2 \mu \mathrm{g} / \mathrm{L}$ in environmental samples might be biased by contamination.

Replicate samples are used to evaluate variability in measurements associated with analytical processes, sample-collection protocols, or natural variation. Replicate samples were collected sequentially after environmental samples. Replicate samples were analyzed for major ions, nutrients, DOC, trace elements, radon, and tritium. Replicate pesticides and VOCs were obtained through collection of environmental matrix-spike samples of those compounds. Precision can be evaluated by comparing concentrations between environmental and replicate samples. Precision is expressed as relative percent difference (RPD) and is computed as

$$
\mathrm{RPD}=\left\{\left|\mathrm{C}_{1}-\mathrm{C}_{2}\right| \div\left[\left(\mathrm{C}_{1}+\mathrm{C}_{2}\right) \div 2\right]\right\} \times 100
$$

where

$\mathrm{C}_{1}$ is the concentration of an analyte measured in the environmental sample, in concentration units; and

$\mathrm{C}_{2}$ is the concentration of the analyte measured in the replicate sample, in the same concentration units. 
Consideration of the magnitude of concentrations being evaluated should be given when evaluating RPDs. For example, the RPD computed from environmental and replicate concentrations of 100 and $101 \mathrm{mg} / \mathrm{L}$ is 1.0 ; the RPD computed from environmental and replicate concentrations of 10 and $11 \mathrm{mg} / \mathrm{L}$ is 9.5 , and the RPD computed from environmental and replicate concentrations of 1 and $2 \mathrm{mg} / \mathrm{L}$ is 67 . Although the difference between environmental and replicate concentrations is the same in each of the examples, the difference evaluated relative to the mean of the measured concentrations increases as the concentrations being evaluated decrease. Constituents measured at small concentrations might yield a large RPD. RPDs were computed only from pairs of analytes that were detected. If one or both analyses in a constituent pair had less-than measurements, then that constituent pair was not evaluated. One major ion analysis and its corresponding replicate had large mass balance (comparison of mass of cations to mass of anions) errors so the mean RPD analysis for that sample set was not considered.

Most mean RPDs computed for major ions and trace elements were less than 5, indicating excellent reproducibility. Mean RPDs larger than 5 and less than 10 resulted for ammonia plus organic nitrogen (RPD = 9), boron (7), and selenium (6). Relatively large RPDs resulted for strontium (15), dissolved phosphorus (15), and DOC (28). Mean RPDs larger than 5 for ammonia plus organic nitrogen, dissolved phosphorus, and DOC result from small concentrations being evaluated in constituent pairs. Constituent pairs had excellent reproducibility for all constituents, except for one strontium sample pair. The strontium RPD computed for this one constituent pair contributed a high bias to the mean RPD for strontium. Strontium RPDs computed for the other sample pairs ranged from 0 to 2.1. In general, mean RPDs computed for constituents indicate that the amount of variability in measurements between environmental and replicate samples is acceptable.

Field spikes are used to assess bias and variability from ground-water matrix interference or degradation of organic constituent concentrations during sample processing, storage, and analysis. Field spikes are environmental samples to which a known volume and concentration of analytes is added. Analytical recoveries of the spiked compounds are expressed as percentages of expected (theoretical) concentrations. Computed field-spike recoveries are compared to theoretical and lab recoveries to evaluate matrix interferences or degradation of organic compounds (pesticides and VOCs).

In addition to field spikes, surrogate compounds are added to environmental samples in the laboratory at the time of analysis. Surrogates are compounds that have a range of expected (observed in the laboratory in 2001) recoveries, usually near 100 percent, and are used to verify that analyses are acceptable. Recovery (percentage) is computed as

$$
\text { Recovery }=\left[\left(\mathrm{C}_{\text {spiked }}-\mathrm{C}_{\text {unspiked }}\right) \div \mathrm{C}_{\text {expected }}\right] \times 100 \text {, }
$$

where

$\mathrm{C}_{\text {spiked }}$ is the measured concentration of analyte in the spiked environmental sample, in micrograms per liter; and

$\mathrm{C}_{\mathrm{unspiked}}$ is the measured concentration of analyte in the unspiked environmental sample, in micrograms per liter.

$\mathrm{C}_{\text {expected }}$ is the theoretical concentration of analyte in the spiked environmental sample, in micrograms per liter, and is computed as

$$
\mathrm{C}_{\text {expected }}=\mathrm{C}_{\text {solution }} \times \mathrm{V}_{\text {spike }} \div \mathrm{V}_{\text {sample }}
$$

where

$\mathrm{C}_{\text {solution }}$ is concentration of analyte in spiked environmental solution, in micrograms per milliliter;

$\mathrm{V}_{\text {spike }}$ is volume of spike added to environmental sample, in milliliters; and

$\mathrm{V}_{\text {sample }}$ is volume of environmental sample, in liters.

Pesticide field spikes and field-spike replicates were added to six environmental samples and their replicates, resulting in 11 spiked samples. Mean percent recoveries were computed for compounds detected: atrazine, 137 percent; deethylatrazine, 79; deisopropylatrazine, 124; deethyldeisopropylatrazine, 133; 2-hydroxyaztrazine, 271; dacthal mono-acid, 98; dicamba, 102; and malathion, 47. Pesticide spike analyses were within laboratory QC limits for surrogate compounds added to the sample prior to analysis, indicating that analytical instrument performance was satisfactory. A very large mean percent recovery for 2hydroxyaztrazine indicates a high bias for this compound. Therefore, actual concentrations probably were considerably less than reported concentrations and might be below the LRL. High biases also were computed for atrazine, deisopropylatrazine, and deethyldeisopropylatrazine. Again, actual concentrations probably were less than reported concentrations. Low bias was observed for malathion. Actual concentrations of this compound probably was higher than reported concentrations. 
VOC field spikes were added to five environmental samples. Mean percent recoveries for the compounds detected were trichloromethane, 102, tetrachloroethene, 85, and tetrahydrofuran, 79. A field spike was not available for methylethylketone. Surrogate VOC spike analyses were as expected for two of the three compounds analyzed. One surrogate compound had a smaller mean recovery than expected, which suggests that matrix interferences might have been observed. The mean percent recovery for trichloromethane was similar to the observed recovery (in the laboratory in 2001) of 97; therefore, concentrations measured in environmental samples probably are similar to actual concentrations. Mean recoveries for tetrachloroethene and tetrahydrofuran were lower than observed (in the laboratory in 2001) but were at or near one standard deviation. Concentrations measured in these samples might be smaller than actual concentrations (low bias).

Ancillary data were collected for wells from which water-quality data were obtained. Ancillary data include selected features or conditions of the well site at the time of sampling, well-construction information, and geologic information. These data included well-construction details such as age of the well, screened interval, casing material, descriptions of the lithologic materials in which the well was installed, and recent or historical activity at the wellhead. Such information is useful for interpretation of results. Ancillary data were particularly useful for interpreting VOC data: Detected compounds probably result from activities at or near the wellhead prior to sampling. 
The southern High Plains is an important habitat for migrating waterfowl.

About one-third of the Nation's beef cattle are raised within 150 miles of Amarillo.

The southern High Plains plateau is dissected by a handful of streams. In some places these streams form dramatic escarpments such as that seen in Palo Duro Canyon. The flat surface of the plateau, ideal for farming, is quite apparent. 

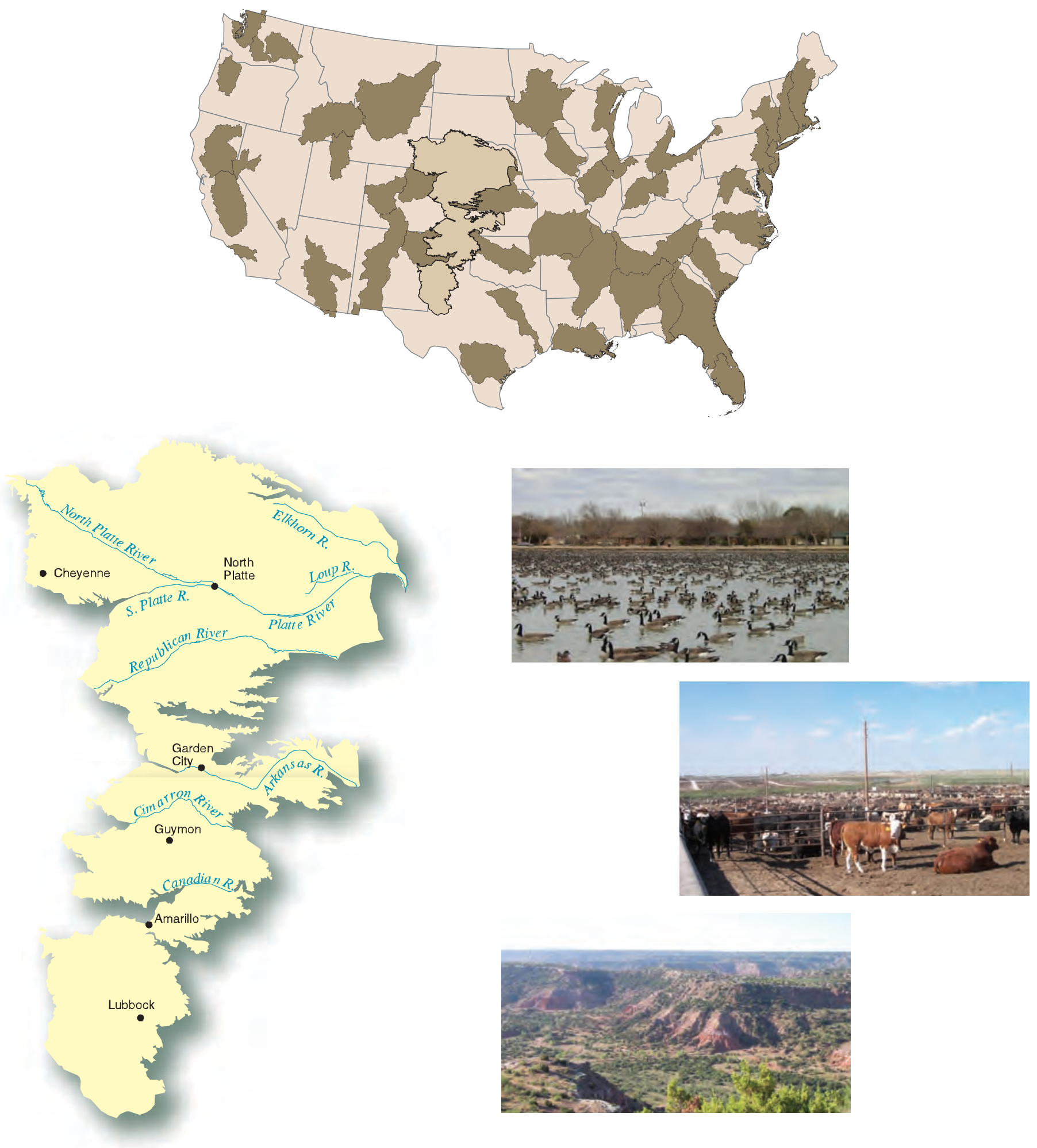

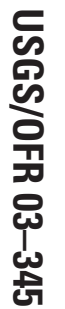

